UNIVERSIDADE DE SÃO PAULO

FACULDADE DE EDUCAÇÃO

Milena Colazingari da Silva

O alunado do curso de Pedagogia de instituições públicas e privadas diversificadas: escolha da profissão, práticas culturais e planos profissionais 


\section{O alunado do curso de Pedagogia de instituições públicas e privadas diversificadas: escolha da profissão, práticas culturais e planos profissionais}

Tese apresentada à Faculdade de Educação da Universidade de São Paulo para obtenção do título de Doutora em Educação.

Área de concentração:

Didática, Teorias de Ensino e Práticas Escolares

Orientadora: Profa. Dra. Paula Perin Vicentini 
AUTORIZO A REPRODUÇÃO E DIVULGAÇÃO TOTAL OU PARCIAL DESTE TRABALHO, POR QUALQUER MEIO CONVENCIONAL OU ELETRÔNICO, PARA FINS DE ESTUDO E PESQUISA, DESDE QUE CITADA A FONTE.

Catalogação na Publicação

Serviço de Biblioteca e Documentação

Faculdade de Educação da Universidade de São Paulo

371.12

S586q
Silva, Milena Colazingari

O alunado do curso de Pedagogia de instituições públicas e privadas diversificadas: escolha da profissão, práticas culturais e planos profissionais / Milena Colazingari da Silva; orientação Paula Perin Vicentini. São Paulo: s. n., 2015.

297 p.; grafs.; tabs.; anexos

Tese (Doutorado - Programa de Pós-Graduação em Educação. Área de Concentração: Teorias de Ensino e Práticas Escolares) - - Faculdade Cade Educação da Universidade de São Paulo.

1. Professores 2. Magistério 3. Ensino Superior

4. Pedagogia

I. Vicentini, Paula Perin, orient. 
Dedico este trabalho ao meu marido Bruno Luís Damineli. Companheiro de todas as horas e apoio inestimável.

Sem você, nada disso teria sido possível.

Muito obrigada por tudo. 


\section{AGRADECIMENTOS}

À Coordenação de Aperfeiçoamento de Pessoal de Nível Superior (CAPES), pelo apoio financeiro a esta pesquisa.

À Profa. Dra. Paula Perin Vicentini, pelo trabalho de orientação e acompanhamento à pesquisa.

Aos Professores Doutores Romualdo Portela de Oliveira e Alda Junqueira Marin, pelas contribuições oferecidas durante o exame de qualificação.

À Profa. Dra. Anne Barrère pelo acompanhamento oferecido à pesquisa durante a realização do doutorado sanduíche no exterior.

Aos professores e coordenadores pedagógicos que tornaram o levantamento de dados dessa investigação possível: Profa. Dra. Ana Maria Domingues Zilocchi (PUC-SP); Profa. Dra. Leda Maria de Oliveira Rodrigues (PUC-SP); Profa. Dra. Maria Luiza Andreozzi (PUC-SP); Profa. Dra. Regina Cândida Ellero Gualtieri (UNIFESP); Profa. Dra. Renata Marcílio Cândido (UNIFESP) e Profa. Dra. Rosario Genta Lugli (UNIFESP).

Ao Centro de Estatística Aplicada (CEA) do IME e aos pesquisadores que contribuíram com o tratamento estatístico desta investigação: Profa. Dra. Chang Chiann, Profa. Dra. Viviana Giampaoli e aos estatísticos Anna Sato, Etienne Mitsuuchi e Simone Harnik.

Aos formandos do curso de Pedagogia, que gentilmente participaram desta investigação. 


\section{RESUMO}

Tomando quatro universidades paulistas com características significativamente distintas (PUC-SP, UNIBAN-Anhanguera, UNIFESP e USP) esta pesquisa, cujo levantamento de dados ocorreu no ano de 2013, intencionou identificar qual o perfil dos formandos do curso de Pedagogia presente em cada uma delas, em seus aspectos socioeconômicos e culturais. Além disso, interessou conhecer as relações existentes entre a origem social dos alunos e o modo como seu deu a escolha profissional; suas representações sobre a profissão docente e as expectativas de trabalho e estudos após a conclusão do curso, em meio a cada um dos quatro grupos de alunos investigados. Para tanto, o desenvolvimento deste estudo envolveu a aplicação de um questionário, cujos dados foram organizados em uma planilha excel, passando por estudos de análise estatística e pelo entrecruzamento das informações por meio do recurso "tabela dinâmica". O exame dos dados, a partir de análise fundamentada nos conceitos sociológicos de Pierre Bourdieu, permitiu identificar que a variação no volume do capital cultural global dos respondentes afetou diretamente o perfil da universidade para o qual os alunos se dirigiram, bem como o processo de escolha profissional vivenciado pelos mesmos. Tal escolha não foi aqui compreendida como fruto de uma decisão deliberada, mas como resultado de uma ação mediada pelo habitus, que dirigiu, tal como na escolha profissional, as práticas culturais, os planos profissionais e formativos, bem como as representações acerca do trabalho docente. Apesar da identificação de variações no peso relativo dos diferentes tipos de capital, verificou-se que a UNIBAN-Anhanguera recebeu os alunos portadores de condições sociais menos privilegiadas, seguida pela UNIFESP. Por outro lado, a PUC-SP e a FEUSP tenderam a receber alunos portadores de um capital econômico e cultural mais elevados. Em termos de práticas culturais notou-se a preferência pelas atividades desempenhadas no meio doméstico, havendo baixo envolvimento dos mesmos com as atividades externas e socialmente mais distintivas. De modo geral, há uma clara preferência pelo consumo de bens massificados, que pouco exigem por parte do receptor em termos da posse de uma apreensão cultural mais elevada. Os planos profissionais e formativos dos respondentes investigados demonstraram um elevado interesse pelo desempenho da profissão, uma vez que grande parte dos mesmos esperam exercer a docência e/ou atuar no âmbito da educação em espaços diversificados. O interesse pela continuidade dos estudos no âmbito da pós-graduação, reforça mais uma vez a adesão dos alunos ao campo de atuação profissional para o qual estavam sendo preparados. Por fim, deve ser destacado que as representações acerca da profissão docente demonstraram a posse por parte dos mesmos de uma clara compreensão acerca da função social contida nessa atividade.

Palavras-chave: Professores, Magistério, Ensino Superior, Pedagogia. 


\begin{abstract}
Using as database four São Paulo universities with significantly different characteristics (PUC-SP, UNIBAN-Anhanguera, UNIFESP and USP) this research, whose data collection occurred in 2013, purposed to identify the profile of graduating students from Pedagogy courses of these four universities, in its socioeconomic and cultural aspects. Furthermore, intended to know the relationship between the student's social background and how happened their career choice, the representations about teaching profession and the career expectations and possibilities of complementary studies after course completion, in each of the four universities investigated. In order to achieve that, the research development consisted in the application of a questionnaire, whose resulted data were organized in an Excel spreadsheet and submitted to statistical analysis and the crossing of information through the "dynamic table" Excel resource. Examination of data from analysis based on sociological concepts from Pierre Bourdieu identified that the variation in the global cultural capital volume of the respondents directly affected the university profile for which students tended towards attending their under-graduation, as well as the process of professional choice experienced by them. This choice was not here understood as the result of a deliberate decision, but due to actions mediated by habitus, who directed, as in the professional choice, cultural practices, professionals and training plans as well as the representations about the teaching work. Despite the identification of variances in the relative weight of the various types of capital, it was found that UNIBAN-Anhanguera received the students with less privileged social conditions, followed by UNIFESP. On the other hand, PUC-SP and FEUSP tended to receive students with higher economic and cultural capital. In terms of cultural practices, it was noted the preference for activities performed in domestic environment, with low involvement with external and socially distinctive activities. Generally, there is a clear preference for the consumption of massiveness market goods, which require minor possession of a higher cultural apprehension. Professional and training plans of the investigated respondents showed a high interest in playing the profession, since a large part of them expect to work as teachers and / or work in education in diversified areas. Their interest in continuing studies in post-graduation courses reinforces once again the adhesion of students to the professional field for which they were being prepared. Finally, it should be highlighted that the representations about teaching profession showed their possession of a clear understanding of the social function embedded in this activity.
\end{abstract}

Keywords: Teacher, Teaching Profession, High Education, Pedagogy. 


\section{SUMÁRIO}

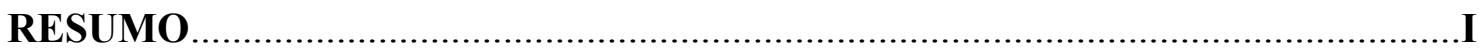

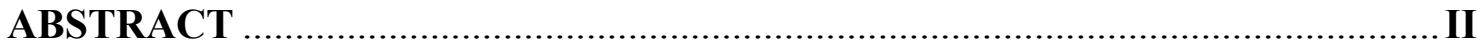

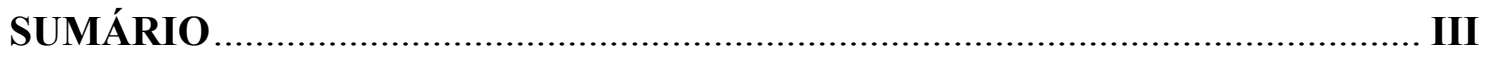

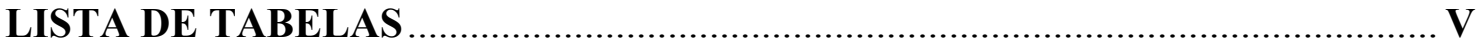

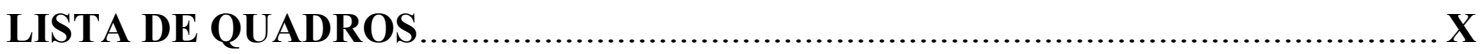

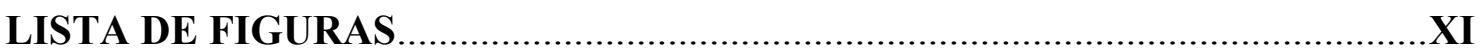

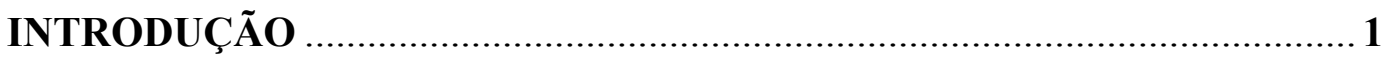

1 O CURSO DE PEDAGOGIA, A EXPANSÃO DO ENSINO SUPERIOR NO BRASIL E AS ESPECIFICIDADES DAS INSTITUIÇÕES INVESTIGADAS.......... 25

1.1 A expansão do ensino superior brasileiro e as especificidades das instituições investigadas

PEDAGOGIA E AO TRABALHO DOCENTE - O CASO UNIBAN-

ANHANGUERA.

2.1 As classes populares em uma instituição popular .................................................. 47

2.2 Realidade e utilitarismo - o possível como orientador das práticas culturais ..................57

2.3 O amor fati, ou o amor ao destino, e a escolha profissional ....................................... 66

3 CURSAR PEDAGOGIA NA UNIFESP DE GUARULHOS: AS EXPECTATIVAS DE GANHOS SIMBÓLICOS E CONCRETOS ENVOLVIDAS

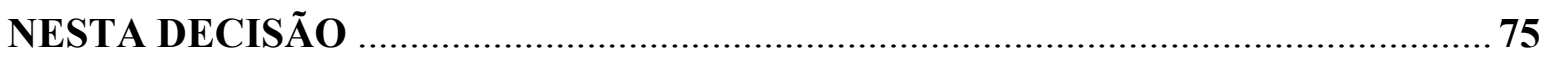

3.1 Relações entre o todo e a parte - o campus de Guarulhos e o curso de Pedagogia da UNIFESP

3.3 A força dos condicionamentos sociais: o abandono do desejado e a adequação ao que é possível.

4 A DIVERSIDADE NO INTERIOR DE UM GRUPO: VARIAÇÕES SOCIOECONÔMICAS, CULTURAIS E DE REPRESENTAÇÃO - O CASO DA PUC/SP. 
4.1 Uma instituição, dois perfis de alunado

4.2 As práticas culturais e a expressão do habitus de classe

4.3 Escolher ou adequar-se? Transformar ou aceitar? Educar ou amar? Estar na escola ou fora dela? As contradições de um grupo

5.1 O perfil social dos respondentes do curso de pedagogia da USP-SP: a fração intermediária das carreiras populares

5.2 A pobreza das práticas culturais e a posse enfraquecida das disposições necessárias para a consolidação de jogadores resistentes 168

5.3 Escolha profissional, perspectivas ocupacionais e formativas: a revelação de agentes comprometidos.

6.1 Senso prático como sentido do jogo: relações entre a instituição universitária, os planos formativos e o perfil socioeconômico dos formandos investigados...

6.2 As universidades e o perfil sociocultural dos formandos investigados: proximidades e distanciamentos

6.3 Escolha profissional, representações acerca da docência e as perspectivas de atuação na área após a conclusão do curso

6.4 A Pedagogia como formação complementar: o sentido da procura do curso entre os docentes em atuação

ANEXO-A - QUESTIONÁRIO APLICADO PARA O LEVANTAMENTO DE DADOS.

\section{APÊNDICE-A - DESCRIÇÃO DETALHADA DAS INSTITUIÇÕES}




\section{LISTA DE TABELAS}

Tabela 1.1 - Volume de matrículas nos cursos presenciais mais procurados em 2009 e 2012

Tabela 1.2 - Volume de matrículas nos cursos a distância mais procurados em 2009 e 2012

Tabela 1.3 - Distribuição dos cursos de Pedagogia do estado de São Paulo, por instituição.....

Tabela 1.4 - Distribuição dos cursos de Pedagogia da cidade de São Paulo, por instituição.

Tabela 2.1 - Distribuição dos respondentes da Uniban/Anhanguera segundo as variáveis sexo, idade, raça e estado civil.

Tabela 2.2 - Distribuição dos respondentes da Uniban/Anhanguera segundo a trajetória escolar, trabalho e intervalo entre o encerramento do ensino médio e ingresso no ensino superior.

Tabela 2.3 - Distribuição dos respondentes da Uniban/Anhanguera segundo o nível de instrução paterno e materno e ocupação desenvolvida pelos mesmos.

Tabela 2.4 - Distribuição dos respondentes Uniban/Anhanguera quanto à renda familiar mensal em salários mínimos, número de pessoas sustentadas e renda familiar per capita.

Tabela 2.5 - Distribuição dos respondentes Uniban/Anhanguera quanto a atividade ocupacional, rendimentos e regime de trabalho durante a graduação

Tabela 2.6 - Distribuição de bolsa de estudos ou financiamento estudantil entre os respondentes da Uniban/Anhanguera

Tabela 2.7 - Atividades mais frequentemente realizadas no tempo livre pelas respondentes da Uniban/Anhanguera

Tabela 2.8 - Listagem dos livros lidos recentemente pelas respondentes da Uniban/Anhanguera.

Tabela 2.9 - Atividades culturais e de lazer realizadas com pouca frequência pelos respondentes da Uniban/Anhanguera

Tabela 2.10 - Listagem do último filme visto no cinema pelos respondentes da Uniban/Anhanguera. 
Tabela 3.1 - Distribuição dos respondentes da UNIFESP segundo as variáveis sexo, idade, raça, estado civil e número de filhos

Tabela 3.2 - Distribuição por campus da cor da pele dos ingressantes da UNIFESP (2011) .77

Tabela 3.3 - Cor da pele ingressantes Guarulhos x curso (2011) 77

Tabela 3.4 - Distribuição dos respondentes da UNIFESP segundo a trajetória escolar e trabalho no ensino médio .78

Tabela 3.5 - Distribuição dos respondentes da UNIFESP segundo o início de curso de graduação anterior à pedagogia

Tabela 3.6 - Distribuição dos respondentes da UNIFESP não graduados anteriormente, em relação ao tempo de permanência no cursinho e intervalo entre a finalização do ensino médio e ingresso no curso de pedagogia.

Tabela 3.7 - Distribuição dos respondentes da UNIFESP não graduados anteriormente, quanto à frequência a cursinhos e a escolha do curso de pedagogia como primeira ou segunda opção formativa

Tabela 3.8 - Origem escolar dos ingressantes da UNIFESP por campus (2011). 80

Tabela 3.9 - Nota de corte dos cursos do campus de Guarulhos (SISU) vestibular $2011 \mathrm{x}$ origem escolar dos alunos aprovados

Tabela 3.10 - Distribuição dos respondentes da UNIFESP segundo o nível de instrução paterno e materno e ocupação desenvolvida pelos mesmos.

Tabela 3.11 - Escolaridade dos pais dos ingressantes da UNIFESP por campus (2011) ....83

Tabela 3.12 - Distribuição dos respondentes UNIFESP quanto à atividade ocupacional, rendimentos e regime de trabalho durante a graduação

Tabela 3.13 - Distribuição dos respondentes UNIFESP quanto à renda familiar mensal e renda familiar mensal per capita.

Tabela 3.14 - Distribuição por turno da renda familiar per capita dos respondentes da UNIFESP .85

Tabela 3.15 - Renda familiar dos ingressantes da UNIFESP por campus (2011) .85

Tabela 3.16 - Cursos com a menor faixa de renda familiar dos ingressantes da UNIFESP de Guarulhos (2011) 86

Tabela 3.17 - Diferença entre os turnos do curso de pedagogia ingressantes (2011) ..........87

Tabela 3.18 - Distribuição do gênero, raça e posse de filhos entre os turnos da 
Tabela 3.19 - Distribuição por turno da trajetória escolar dos respondentes da UNIFESP

Tabela 3.20 - Distribuição por turno do nível de instrução familiar e ocupações dos respondentes da UNIFESP .

Tabela 3.21 - Atividades mais frequentemente realizadas no tempo livre pelos respondentes da UNIFESP

Tabela 3.22 - Distribuição dos gêneros musicais apreciados pelos respondentes da UNIFESP

Tabela 3.23 - Frequência da leitura de revistas e jornais entre os respondentes da UNIFESP

Tabela 3.24 - Atividades culturais e de lazer realizadas com pouca frequência pelos respondentes da UNIFESP . 100

Tabela 3.25 - Bairros ocupados pelos respondentes da UNIFESP no município de São Paulo 103

Tabela 4.1 - Distribuição dos respondentes da PUC/SP segundo as variáveis sexo, idade, raça, estado civil e número de filhos

Tabela 4.2 - Distribuição dos respondentes da PUC/SP segundo a trajetória escolar e trabalho no ensino médio. 124

Tabela 4.3 - Distribuição dos respondentes da PUC/SP segundo o início de curso de graduação anterior à pedagogia

Tabela 4.4 - Distribuição dos respondentes da PUC/SP em relação ao tempo de permanência no cursinho e intervalo entre a finalização do ensino médio e ingresso no curso de pedagogia como primeira graduação

Tabela 4.5 - Distribuição dos respondentes da PUC/SP segundo o nível de instrução paterno e materno e ocupação desenvolvida pelos mesmos

Tabela 4.6 - Distribuição dos respondentes PUC/SP quanto à atividade ocupacional, rendimentos e regime de trabalho durante a graduação

Tabela 4.7 - Distribuição dos respondentes PUC/SP quanto à renda familiar mensal per capita

Tabela 4.8 - Distribuição do gênero, raça e posse de filhos entre os turnos da PUC/SP ... 128

Tabela 4.9 - Distribuição da trajetória escolar entre os turnos da PUC/SP .

Tabela 4.10 - Distribuição do nível de instrução e ocupação paterno e materno entre os turnos da PUC/SP 
Tabela 4.11 - Distribuição da renda familiar per capita entre os respondentes da $\mathrm{PUC} / \mathrm{SP}$ 130

Tabela 4.12 - Distribuição de bolsas de estudo ou financiamento estudantil entre os turnos da PUC/SP

Tabela 4.13 - Distribuição de bolsa de estudos ou financiamento estudantil entre os respondentes da PUC/SP

Tabela 4.14 - Atividades mais frequentemente realizadas no tempo livre pelos respondentes da $\mathrm{PUC} / \mathrm{SP}$

Tabela 4.15 - Distribuição dos gêneros musicais apreciados pelos respondentes da PUC/SP 134

Tabela 4.16 - Frequência da leitura de livros, revistas e jornais entre os respondentes da PUC/SP 136

Tabela 4.17 - Atividades culturais e de lazer realizadas com pouca frequência pelos respondentes da PUC/SP

Tabela 5.1 - Distribuição dos respondentes da FEUSP segundo as variáveis sexo, idade, raça, estado civil e número de filhos

Tabela 5.2 - Distribuição dos respondentes da FEUSP segundo a trajetória escolar no ensino médio. 154

Tabela 5.3 - Distribuição dos respondentes da FEUSP segundo a jornada de trabalho e cursinho no ensino médio. 155

Tabela 5.4 - Distribuição dos respondentes da FEUSP não graduados anteriormente, em relação ao tempo de permanência no cursinho e intervalo entre a finalização do ensino médio e ingresso no curso de Pedagogia.

Tabela 5.5 - Distribuição dos respondentes da FEUSP não graduados anteriormente, quanto à frequência a cursinhos e a escolha do curso de pedagogia como primeira ou segunda opção formativa

Tabela 5.6 - Distribuição dos respondentes da FEUSP segundo o nível de instrução paterno e materno e ocupação desenvolvida pelos mesmos.....

Tabela 5.7 - Distribuição da renda familiar per capita mensal entre os respondentes da FEUSP 158

Tabela 5.8 - Distribuição dos respondentes FEUSP quanto à atividade ocupacional, rendimentos e regime de trabalho durante a graduação .....

Tabela 5.9 - Cursos com menor nota de corte no vestibular da FUVEST para carreiras oferecidas no campus de São Paulo. 
Tabela 5.10 - Atividades mais frequentemente realizadas no tempo livre pelos respondentes da FEUSP

Tabela 5.11 - Frequência da leitura de revistas e jornais entre os respondentes da FEUSP..

Tabela 5.12 - Distribuição dos gêneros musicais apreciados pelos respondentes da FEUSP 174

Tabela 5.13 - Atividades culturais e de lazer realizadas com pouca frequência pelos respondentes da USP . 175

Tabela 5.14 - Bairros ocupados pelos respondentes da FEUSP no município de São Paulo. 179

Tabela 6.1 - Associação entre opção pelo curso de Pedagogia x instituição 217

Tabela 6.2 - Associação entre turno de estudos no ensino médio e opção pelo curso de Pedagogia 218

Tabela 6.3 - Associação entre ocupação materna e opção pelo curso de Pedagogia 218

Tabela 6.4 - Associação entre opção pelo curso de Pedagogia x renda per capita familiar. 218

Tabela 6.5 - Associação entre opção pelo curso de Pedagogia e frequência da leitura de livros 218

Tabela 6.6 - Distribuição dos respondentes de acordo com o grupo de disciplinas que mais contribuiu com sua formação em Pedagogia

Tabela 6.7 - Distribuição dos respondentes de acordo com o interesse pela docência em instituições públicas ou privadas de ensino 


\section{LISTA DE QUADROS}

Quadro 1.1 - Características gerais das universidades em estudo 44

Quadro 3.1 - Listagem dos livros lidos recentemente pelos respondentes da UNIFESP ....93

Quadro 3.2 - Listagem das revistas lidas pelos respondentes da UNIFESP .95

Quadro 3.3 - Listagem do último filme visto no cinema - UNIFESP. .99

Quadro 3.4 - Lista da última peça de teatro assistida - UNIFESP 101

Quadro 4.1 - Listagem das revistas lidas pelos respondentes da PUC/SP 137

Quadro 4.2 - Listagem dos livros lidos recentemente pelos respondentes da PUC/SP .... 139

Quadro 4.3 - Listagem do último filme visto no cinema pelos respondentes da PUC/SP.140

Quadro 4.4 - Lista da última peça de teatro assistida - PUC/SP 144

Quadro 5.1 - Listagem dos livros lidos recentemente pelos respondentes da FEUSP ...... 170

Quadro 5.2 - Listagem das revistas lidas pelos respondentes da FEUSP 172

Quadro 5.3 - Listagem do último filme visto no cinema pelos respondentes da FEUSP .. 176

Quadro 5.4 - Lista da última peça de teatro assistida - FEUSP 178

Quadro 6.1 - Distribuição dos respondentes docentes portadores de formação específica para o magistério 


\section{LISTA DE FIGURAS}

Gráfico 4.1 - Apresentação gráfica da distribuição da renda familiar per capita mensal entre os turnos da PUC/SP

Gráfico 5.1 - Apresentação gráfica da distribuição da renda familiar per capita mensal entre os turnos - FEUSP

Gráfico 5.2 - Evolução do percentual de alunos que iniciaram ou concluíram outra graduação dos cursos de pedagogia, direito, engenharia e medicina

Gráfico 5.3 - Evolução do percentual de alunos ingressantes nos cursos de medicina e licenciatura em pedagogia, matemática e física de acordo com a rede de ensino em que cursaram o ensino médio (2011-2015): a) rede pública; b) rede particular. 164

Gráfico 5.4 - Evolução percentual do grau de escolaridade dos pais dos cursistas ingressantes nas graduações de medicina e licenciatura em pedagogia, matemática e física (2011-2015): a) pais que cursaram ensino fundamental; b) pais que cursaram ensino médio; c) pais que cursaram ensino superior 165

Gráfico 5.5 - Evolução percentual do grau de escolaridade das mães dos cursistas ingressantes nas graduações de medicina e licenciatura em pedagogia, matemática e física (2011-2015): a) mães que cursaram ensino fundamental; b) mães que cursaram ensino médio; c) mães que cursaram ensino superior 165

Gráfico 5.6 - Evolução percentual da renda familiar mensal dos cursistas ingressantes nas graduações de medicina e licenciatura em pedagogia, matemática e física (20112015): a) < 2 salários mínimos; b) 2 a 5 salários mínimos.

Gráfico 5.7 - Evolução percentual da renda familiar mensal dos cursistas ingressantes nas graduações de medicina e licenciatura em pedagogia, matemática e física (20112015): a) 5 a 10 salários mínimos; b) > de 10 salários mínimos. 167

Gráfico 6.1 - Distribuição dos alunos segundo sexo por instituição. 221 


\section{INTRODUÇÃO}

Tomando quatro universidades paulistas com características significativamente distintas (PUC-SP, UNIBAN-Anhanguera, UNIFESP e USP), esta pesquisa tem por intenção identificar qual o perfil dos formandos do curso de Pedagogia presente em cada uma delas, em seus aspectos socioeconômicos e culturais. Além disso, interessa conhecer o processo de escolha profissional, as representações sobre a profissão docente e as expectativas de trabalho e estudos após a conclusão do curso, existentes em cada um dos quatro grupos de alunos investigados.

Tendo por referencial teórico fundamental os conceitos formulados pelo sociólogo francês Pierre Bourdieu - tais como: habitus, capital cultural, capital econômico, entre outros - a expectativa desta investigação é identificar o modo como a origem social dos alunos conduziu o ingresso dos mesmos em uma dada universidade, bem como influenciou suas práticas culturais; seu processo de escolha do curso e seus planos profissionais, formativos, além de suas representações sobre a profissão docente.

O interesse pelo tema desta pesquisa surgiu a partir da minha experiência como docente no curso de graduação em Pedagogia, no âmbito de uma instituição particular de ensino superior paulista. Durante meus sete anos de trabalho, desenvolvi o hábito de perguntar aos alunos ingressantes, o motivo pelo qual foram levados a frequentar o curso que estavam iniciando. Dentre as respostas oferecidas, uma mostrou-se recorrente ao longo do tempo: a que indicava o desejo inicial destes alunos de frequentarem outra graduação, completamente diferente e distante do curso de Pedagogia. Na presença de turmas numerosas, chamava minha atenção o índice elevado de estudantes que ali estavam, sem que necessariamente desejassem seguir a carreira para a qual iniciavam seu preparo. A partir de seus depoimentos era possível notar que a "escolha" profissional foi orientada, acima de tudo, pela condição financeira do aluno e de sua família. Cursos integrais, de longa duração ou de custo elevado, eram descartados - assim, muitos estudantes deixavam de seguir graduações em Psicologia ou Direito, pelo fato de suas mensalidades serem mais elevadas e do tempo de formação ser mais longo, em relação ao curso de Pedagogia. Para aqueles alunos, a possibilidade de adquirirem um diploma de nível superior em no máximo três anos, pagando uma mensalidade baixa, fazia do curso de Pedagogia uma formação mais viável e atrativa que as demais graduações ofertadas pela mesma universidade. Diante deste quadro, algumas questões passaram a me preocupar. Afinal, quem são os estudantes do curso de Pedagogia? Como estes alunos escolhem sua profissão? Por qual 
motivo muitos cursistas da graduação em Pedagogia iniciam essa formação sem ter um interesse verdadeiro pelo mesmo?

Enquanto diante dos alunos de primeiro ano do curso de Pedagogia era interessante conhecer os motivos da escolha profissional, diante das turmas de formandos meu questionamento era dirigido para as expectativas profissionais dos mesmos. Como resultado, fui novamente surpreendida pelo grande número de alunos que afirmavam não desejar o exercício da profissão, mesmo após a conclusão do curso. Dentre as justificativas apresentadas, muitos alegavam a baixa remuneração oferecida pelas escolas, criticavam as condições de trabalho ou simplesmente alegavam não ter interesse pela atividade profissional do pedagogo. Tal posicionamento dos alunos novamente gerou um conjunto de questionamentos a respeito dos estudantes do curso de Pedagogia: O que leva os alunos a recusarem a profissão? O que estes alunos pensam da profissão para a qual estão sendo preparados? A desvalorização social da profissão docente repercute nos modos de compreender a profissão destes alunos? Teria relação com esse posicionamento o fato de grande parte destes estudantes terem cursado uma formação inicialmente não desejada?

As indagações acima apresentadas terminaram por motivar a elaboração da pesquisa, cujos resultados são apresentados aqui. Cabe destacar que o tipo de preocupação mobilizadora desta investigação não é recente. Em 1960, Aparecida Joly Gouveia desenvolveu um estudo que procurou relacionar a escolha ocupacional das normalistas mineiras e paulistas com sua origem familiar e seus valores. De acordo com os resultados desse estudo, verificou-se que o desejo de exercer o magistério era mais frequente entre as jovens pertencentes às famílias das classes populares. Assim, a pesquisadora constatou que pais com pouca escolaridade e ocupação profissional modesta tendiam a levar suas filhas para a escolha do magistério. Além do aspecto econômico, a autora identificou que o desejo de exercer a docência era mais presente entre as alunas com baixo aproveitamento escolar. Por outro lado, as jovens oriundas de famílias portadoras de menor poder aquisitivo, mas que possuíam ótimo aproveitamento escolar terminavam por rejeitar o trabalho docente como profissão.

Em pesquisa contemporânea, Louzano et. al. (2010) retomam algumas das questões identificadas por Gouveia (1970), por meio da discussão dos problemas enfrentados pelo Brasil no processo de seleção e contratação de bons professores. Em suas palavras, "o Brasil atrai indivíduos com baixo rendimento acadêmico e com perfil socioeconômico mais baixo para cursos de formação de professores." (p. 543). Essa caracterização dos que desejam seguir o magistério resulta, possivelmente, da desvalorização da profisssão, marcada pelas condições 
adversas de trabalho, pelo baixo reconhecimento público, além da falta de autonomia dos professores na direção do seu trabalho e pouca possibilidade de participação nas definições das políticas públicas em educação.

Pereira (2001), ao investigar os valores do magistério público paulista durante a década de 1980, por meio do estudo de dois periódicos publicados por associações docentes - o Centro do Professorado Paulista e o Sindicato dos Professores do Ensino Oficial do Estado de São Paulo, afirma que a partir das fontes foi possível identificar a "miséria de posição" então ocupada pelos professores. Termo emprestado do sociólogo francês Pierre Bourdieu, forjado em sua obra A Miséria do Mundo, a "miséria de posição" do magistério tem relação com a ocupação pelos docentes de um lugar dominado no espaço social - onde seu trabalho e saberes profissionais são desvalorizados e suas reivindicações ignoradas por parte do governo. Os professores demonstravam sua insatisfação ao se queixarem dos baixos salários; do trabalho em escolas deterioradas, da falta de recursos materiais e didáticos para o desenvolvimento de suas atividades, da ausência de respostas e ações governamentais para solucionar os problemas experimentados pela categoria, colocando-os na situação de vivenciarem um "permanente estresse reinvidicatório" (PEREIRA, 2001, p.45). Ao mesmo tempo, os problemas de saúde associados ao trabalho docente eram correntemente relatados, tanto no âmbito das doenças físicas, quanto mentais.

O descontentamento expresso pelos professores tem relação, de certa maneira, com o desprestígio vinculado à profissão, o qual possui diferentes origens e justificativas. Um primeiro fator promotor da desvalorização diz respeito à depreciação do trabalho desempenhado pelos docentes, considerado como pouco criativo e marcado pela mera reprodução de saberes elaborados intelectualmente por outros. As aulas, por sua vez, são entendidas como de qualidade duvidosa, compreensão que é reforçada pelo conhecimento de que a formação cultural destes docentes não é tão vasta e diversa ${ }^{1}$.

Mills (1969, p.148), ao identificar os professores como representantes menos prestigiosos da nova classe média americana, já denunciava a desvalorização da profissão ao traçar o perfil social e cultural dos que eram atraídos para a docência: de origem popular, tratava-se de um grupo que "(...) não é particularmente notável por seus méritos intelectuais, flexibilidade ou extensão de cultura, ou amplitude de imaginação." De acordo com o autor, os

\footnotetext{
${ }^{1}$ A respeito dos hábitos culturais dos professores consultar: SETTON, M. da G. J. Professor: um gosto de classe. Dissertação de mestrado, PUC-SP, 1989. CRUZ, L. L da. Magistério e cultura: a formação cultural dos professores e sua percepção das potencialidades educativas dos museus de arte. Dissertação de mestrado. PUCSP, 2008.
} 
professores eram pessoas que ascenderam na posição de classe pela aquisição de saberes profissionais especializados, porém, mantiveram nas práticas culturais a marca da sua origem social.

O tipo de conhecimento e formação cultural dos professores correspondia, de acordo com Mills (1969), com o gênero dos saberes exigidos para o desempenho da função docente conhecimento especializado, para o desempenho de uma função técnica que não demanda criatividade para o seu exercício, nem posicionamento político. Além disso, os professores restringiam-se à tarefa de ensinar os conhecimentos que foram produzidos por outros, atuando como meros reprodutores de informações.

A dúvida em torno das competências profissionais do professor dá-se a partir do tipo de formação necessária ao exercício da profissão, por vezes obtida no âmbito do ensino médio ou na conclusão de uma "educação superior curta, de menor prestígio que a universitária em sentido estrito" (FERNANDES ENGUITA, 1991, p.45). Diante do entendimento de que o professor possui uma formação pouco qualificada, os sistemas de administração escolar terminam por oferecer materiais didáticos tais como livros, apostilas, esquemas e textos, prontos para serem utilizados pelos professores, transformando o ensino em uma tarefa técnica, evidenciando a desqualificação docente, sendo este um dos elementos colaboradores do processo de proletarização da categoria (FERNANDES ENGUITA, 1991; LAWN; OZGA, 1991).

Braverman (1980) identifica os empregados especializados, com inclusão dos que atuam no espaço escolar, como uma classe trabalhadora que não possui independência econômica e ocupacional, consequência da ausência de acesso dos mesmos ao processo de trabalho ou meios de produção, para além da situação de trabalho. Formalmente, o autor nivela esse grupo de profissionais aos trabalhadores proletários, que vivenciam a dissociação entre a execução de um trabalho racionalizado e a função de planejamento do mesmo, a qual lhes foi retirada.

A introdução na escola das práticas administrativas empresariais, as quais, visando à eficiência do processo educativo, transferiram aos especialistas em educação a atividade de planejamento do trabalho docente, acentuou a perda de autonomia dos professores, que passaram a receber propostas de trabalho previamente estruturadas no que se refere ao currículo a ser utilizado; programas; atividades a serem desenvolvidas com os alunos; avaliações; seleção de textos e até métodos de ensino. Há, portanto, perda de controle do professor sobre o seu próprio trabalho, situação esta que desqualifica o docente, diante da desvalorização de seus 
conhecimentos e da sua capacidade exercer com competência sua própria profissão (FERNANDES ENGUITA, 1991; LAWN; OZGA, 1991). O trabalho do professor foi fragmentado, cabendo-lhe a tarefa de executar planos e objetivos de trabalho que lhes são alheios, além disso, o professor submeteu-se a uma constante vigilância das suas atividades, diante do aumento do controle administrativo que chegou a propor o condicionamento da remuneração docente, ao resultado da avaliação do desempenho deste professor em suas atividades profissionais (LAWN; OZGA, 1991).

Arroyo (1985) identifica o estabelecimento do processo de "divisão do trabalho pedagógico" à institucionalização dos Grupos Escolares no final do século XIX, cuja organização interna envolvia a hierarquização do trabalho, acompanhada da função disciplinadora do diretor que fiscalizava e controlava alunos, funcionários e professores. De acordo com o autor, essa percepção de organização do trabalho pedagógico decorreu do imaginário de administradores paulistas e mineiros que desejaram transportar a lógica empresarial para o interior da administração pública. Para tanto, foi configurado um novo perfil docente, que se aproximou da imagem do trabalhador empresarial, cujos esforços seriam recompensados a partir dos resultados observados na aprendizagem dos estudantes e no exercício eficiente do seu trabalho. Arroyo destaca que essa nova concepção organizacional do trabalho escolar, presente nas políticas pedagógicas dos educadores do início do século, marcou o trabalhador do ensino, cuja prática foi desqualificada, enquanto a classe profissional dos docentes foi politicamente enfraquecida.

O questionamento em torno dos conhecimentos detidos pelos professores aliado ao processo de queda de qualidade do ensino público terminou por afetar ainda mais a imagem destes profissionais. A escola pública é criticada não só por suas deficiências materiais, mas pela qualidade do trabalho educativo realizado na instituição, que não passou por adequações diante do processo de ampliação das oportunidades escolares. A massificação do atendimento escolar no Brasil e a inserção da população detentora de baixos recursos econômicos, fez com que a escola perdesse seu valor distintivo, juntamente com os profissionais que nela atuavam (PEREIRA, 2001). Esse mesmo processo foi relatado por Mills (1969, p.148), no interior da sociedade norte americana, ao afirmar que o grande número de professores existentes, voltados para o atendimento da demanda crescente de alunos, resultado da massificação do ensino, terminou por contribuir com o desprestígio da profissão, tornando-a pouco atrativa para "os filhos de famílias cultas da classe superior." 
Ao discutir as transformações sociais que ocorreram nos Estados Unidos entre os séculos XIX e XX, provocadas pelo progresso tecnológico que mecanizou o processo produtivo, Mills (1969) indica a consolidação de uma nova classe média constituída pelos "colarinhos brancos": trabalhadores assalariados, que não mais detinham os meios de produção e contavam apenas com a possibilidade de venda da sua força de trabalho. No interior desta nova classe média, existia uma hierarquização dos grupos ocupacionais, definida a partir dos diferentes níveis de renda. Os grupos ocupacionais mais numerosos eram os que acumulavam menor rendimento mensal e abrangiam as categorias profissionais dos professores, dos vendedores e dos empregados de escritório. Em geral, nos anos de 1940, a renda dos "colarinhos brancos" era superior a dos operários, porém, já neste período, ocorria praticamente uma equiparação salarial entre os grupos ocupacionais numerosos e os operários qualificados e contramestres. Assim, a diferença entre as categorias de mais baixo salário das novas classes médias e os operários qualificados e contramestres, residia no prestígio social decorrente do tipo de trabalho realizado, que exigia certo nível de especialização adquirido pela educação formal - os operários estudavam pelo período de oito anos, enquanto um "colarinho branco" deveria completar doze anos de estudo. Os professores, situados entre as categorias de menor distinção da nova classe média, são apresentados por Mills (1969, p. 147) como o grupo mais numeroso e, do ponto de vista econômico, foram identificados como "proletários das profissões liberais". A proletarização do trabalho docente, a partir da perspectiva apontada por Mills, relaciona-se com a aproximação do salário recebido pelos professores e operários, e a decorrente diminuição das diferenças sociais entre estas duas categorias profissionais (PEREIRA, 2001).

Dentre os diversos determinantes da desvalorização do magistério, o problema da remuneração salarial é o mais recorrentemente relatado. Vicentini e Lugli (2009) destacam que já durante o século XIX, no Brasil, havia relatos que indicavam a falta de docentes para o exercício da profissão, devido aos baixos salários oferecidos, fazendo com que ninguém desejasse assumir os cargos de mestres de primeiras letras e gramática latina. Além disso, entre os séculos XIX e XX, foram noticiadas práticas de rebaixamento salarial e atrasos no pagamento, ações comuns que fizeram com que os professores reivindicassem não só o aumento dos seus salários, mas também a regularização das suas remunerações.

A desconsideração para com os salários dos professores foi associada, por alguns pesquisadores, à feminização da docência, elemento também entendido como contribuinte do processo de proletarização da profissão, desqualificada pela predominância feminina (LAWN; 
OZGA, 1991). Nas séries iniciais, o ensino é entendido como atividade adequada às mulheres, já que no interior da ideologia patriarcal, trata-se de uma atividade transitória, que prepara as jovens para o exercício da maternidade (FERNANDES ENGUITA, 1991). O entendimento da docência nas séries iniciais, como atividade próxima ao sexo feminino, se relaciona com a divisão sexual do trabalho que identifica características da personalidade feminina tais como docilidade, paciência e meiguice - como atributos apropriados ao trabalho a ser executado. Há, portanto, a percepção de que o trabalho do professor primário é uma "espécie de extensão profissionalizada dos papéis maternos" (PEREIRA, 1969, p.51). Também em decorrência da estrutura patriarcal das sociedades ocidentais, o magistério é entendido como atividade profissional feminina pelo fato de permitir que sejam conciliadas as tarefas domésticas, entendidas como responsabilidade própria das mulheres, com as profissionais - sendo a jornada de trabalho docente da escola primária um contributo à junção das duas atribuições (PEREIRA, 1969).

A baixa remuneração destinada ao pagamento do salário dos professores terminou por fazer da profissão uma atividade não atrativa para os homens, os quais assumiram na divisão sexual das responsabilidades familiares, o dever de sustentar a família. Por outro lado, a permanência das mulheres neste trabalho, demonstrando aceitação do valor pago, deveu-se a percepção partilhada socialmente de que o salário feminino constituía-se em uma segunda fonte de renda, ideia esta que terminou por favorecer a manutenção dos baixos salários (FERNANDES ENGUITA,1991).

Moriconi (2008), em dissertação de mestrado a respeito da remuneração dos professores das escolas públicas, avaliou a atratividade salarial dos mesmos por meio do cálculo das distâncias entre o salário dos professores públicos e os rendimentos que eles receberiam se atuassem em um dos três seguintes grupos de comparação: demais ocupações do setor público, demais ocupações do setor privado e como professores do setor privado. Dentre seus resultados a autora observou que um professor que trabalha na escola pública ganha, em média, 36\% menos do que outros trabalhadores qualificados, considerando-se o setor privado como base de comparação. Por sua vez, quando o salário é comparado com o de professores da rede privada, a redução é de 19\%. Por fim, quando o salário dos professores públicos é comparado com o de outros funcionários deste mesmo setor, aqueles recebem até $52 \%$ a menos. Considerando a remuneração a partir do tempo de carreira, a autora constatou que os salários iniciais são pouco atrativos, quando comparados com os de outras profissões, tanto no setor privado quanto 
público. Além disso, a diferença salarial aumenta ao longo dos anos de carreira, o que termina por fazer do trabalho docente uma profissão não promissora também em longo prazo.

Além dos baixos salários, as condições de trabalho enfrentadas pelos professores cotidianamente afetam o interesse pelo ingresso ou permanência na profissão. Dentre os elementos que tornam a condição do trabalho docente adversa, convém mencionar: o número excessivo de alunos por classe; a carência de recursos materiais; problemas com relação ao reconhecimento de sua autoridade frente a pais e alunos; dificuldade com as questões disciplinares na sala de aula; sistema de ensino burocrático e centralizador e sua consequente proletarização; vivência de relações autoritárias no interior da escola; convivência com situações de violência, burocratização do trabalho; sobrecarga de tarefas, dentre outros. Todos estes elementos fazem do trabalho docente uma atividade profissional desprovida de reconhecimento e prestígio (PENNA, 2011).

O sentimento de insatisfação profissional vivenciado pelos docentes em exercício, expressos em comentários e atitudes no espaço da sala de aula, terminam por serem notados entre os alunos destes professores. Essa percepção, de acordo com Gatti (2010), favorece o desinteresse dos jovens pela escolha dessa atividade como profissão. A falta de interesse das novas gerações pelo trabalho docente repercute no baixo número de estudantes matriculados nos cursos de licenciatura e, por consequência, na falta de professores habilitados para o exercício do magistério. Em 2007, o Conselho Nacional de Educação, realizou um estudo sobre o Ensino Médio que constatou a falta de profissionais qualificados para ministrarem as disciplinas de Física, Química, Matemática e Biologia.

O fenômeno do decréscimo da demanda pela carreira docente, entretanto, não é especificamente brasileiro. O tema é objeto de estudo em vários países tais como Austrália, Coréia do Sul, Dinamarca, Espanha, Estados Unidos, Reino Unido, Suécia, entre outros, que se defrontam com problema, uma vez que o mesmo possui relação direta com a construção de um sistema de ensino qualificado (LEME, 2009; 2012; LOUZANO et. al., 2010). Organismos internacionais como a Organização Internacional do Trabalho (OIT) e a Organização das Nações Unidas para a Educação, Ciência e Cultura (Unesco), também estão voltados para a problemática. Ambas se pronunciaram no ano de 2008, expressando preocupação com a desvalorização do magistério, bem como com a falta de interesse entre os jovens de seguirem esta profissão (GATTI, 2010).

De acordo com Gatti (2010), a falta de atratividade do trabalho docente tem aproximado da carreira indivíduos portadores de uma formação básica bastante deficitária. 
Diferentemente da Finlândia, cujos ótimos resultados obtidos no Programa Internacional de Avaliação de Estudantes (PISA) vinculam-se a uma forte política de atração dos melhores alunos para o exercício da docência, o Brasil atrai para a profissão estudantes que possuem dificuldades para escrever, ler e compreender um texto:

Em resumo, trata-se de alunos que tiveram dificuldades de diferentes ordens para chegar ao ensino superior. São estudantes que, principalmente pelas restrições financeiras, tiveram poucos recursos para investir em ações que lhes permitissem maior riqueza cultural e acesso a leitura, cinema, teatro, eventos, exposições e viagens. E essa mudança de perfil trouxe implicações para os cursos de Licenciatura que estão tendo que lidar com um novo background cultural dos estudantes (GATTI, 2010, p.149).

Atentando para as circunstâncias que envolvem o trabalho docente, resultantes da desvalorização social da profissão, a pesquisa aqui apresentada tem por interesse: a) identificar as variações no perfil socioeconômico e cultural dos estudantes do curso de Pedagogia; b) conhecer como se deu o processo de escolha profissional; c) distinguir as expectativas profissionais e formativas dos mesmos após a conclusão do curso; d) especificar as representações que os mesmos possuem acerca do trabalho do docente. Tais aspectos serão observados, ainda, a partir de um recorte institucional, já que este estudo envolveu formandos do curso de Pedagogia de quatro diferentes universidades, públicas e privadas, localizadas no estado de São Paulo. Dentre as instituições privadas, participaram da pesquisa a Pontifícia Universidade Católica de São Paulo (PUC-SP) e a Universidade Bandeirante Anhanguera (UNIBAN-Anhanguera), campus Morumbi. No âmbito das instituições públicas foram investigados os alunos da Faculdade de Educação da Universidade de São Paulo (FEUSP) e os alunos da Universidade Federal de São Paulo (UNIFESP). A escolha das universidades considerou as diferenciações existentes entre as mesmas, tal como tradicionalismo; objetivos institucionais e formativos; tempo de funcionamento; processo seletivo utilizado para o ingresso dos alunos, localização e valor da mensalidade - no caso das particulares, tendo em vista o interesse em incluir neste estudo alunos com perfis bastante diversificados em termos da posse de capital econômico, cultural e social, cuja heterogeneidade permitirá verificar o modo como a origem social desses estudantes afetou o direcionamento dos mesmos para cada uma dessas universidades, assim como influenciou o encaminhamento dos mesmos para o curso de Pedagogia e suas escolhas atuais em termos de planos formativos e profissionais, além de suas representações sobre a profissão.

O delineamento do perfil dos alunos e de suas representações foi produzido a partir da aplicação de questionário que pretendeu identificar desde o gênero, idade e raça dos alunos, até informações gerais sobre a trajetória escolar; a origem sociocultural e econômica; as condições 
de ingresso no ensino superior; a escolha e as expectativas profissionais e os hábitos culturais desses estudantes. No que se refere à identificação das representações, a mesma se deu por meio da utilização de questões dissertativas no interior do mesmo questionário, as quais investigavam o processo de escolha profissional; as ideias sobre a profissão e trabalho docente, bem como as expectativas profissionais existentes em meio a esse grupo.

O levantamento bibliográfico realizado em busca de pesquisas com temáticas afins ao da investigação aqui proposta permitiu a identificação de um conjunto de sete dissertações e três teses. ${ }^{2}$ De modo geral, as investigações sobre a maneira de pensar dos alunos do curso de Pedagogia abrangeu principalmente os processos de escolha e as expectativas profissionais dos mesmos (LEME, 2012; BRANDÃO, 2012; DINIZ, 2010; SOUZA, L. O., 2010; SOUZA, 2009; OLIVEIRA, 2001). As demais pesquisas voltaram-se à investigação do posicionamento dos estudantes ante o trabalho docente e seu processo formativo (PETTERS, 2009; SOUZA, A. C., 2010; BRAZ, 2006). Neste último caso, Souza, A. C (2010) 3 e Braz (2006) desenvolveram pesquisas complementares, visto que a primeira destinou-se a investigar como o curso de Pedagogia é aproveitado por alunos que já atuam como docentes, ao mesmo tempo em que apurou os motivos que fazem com que profissionais ativos do magistério recorram a este tipo de formação. Em suas conclusões, Souza, A. C (2010) identificou que o curso de Pedagogia é tomado por estes professores como um espaço de formação continuada, tendo em vista o desejo de discutir suas práticas cotidianas, a partir da formação teórica proporcionada pelo curso. Essa percepção aproxima-se da conclusão do estudo elaborado por Braz (2006) a respeito das representações dos alunos do curso de Pedagogia sobre a prática docente nos anos iniciais do ensino fundamental. Nesta investigação, a partir de três delimitações sobre o que vem a ser o trabalho do professor primário: a) atividade profissional; b) atividade técnica ou c) atividade leiga, identificou-se que os estudantes concebem de forma mais recorrente a docência como atividade profissional, entretanto, a compreensão deste trabalho como atividade técnica e leiga

\footnotetext{
${ }^{2}$ Estes trabalhos foram localizados a partir da consulta aos seguintes catálogos: a) Biblioteca da Faculdade de Educação da Universidade de São Paulo; b) Biblioteca da Pontifícia Universidade Católica de São Paulo; c) Biblioteca Digital Brasileira de Teses e Dissertações; d) Banco de teses da Coordenação e Aperfeiçoamento de Pessoal de Nível Superior (CAPES); e) Banco de teses da Universidade de São Paulo (USP); f) Banco de teses da Universidade Estadual de Campinas (UNICAMP) e g) Banco de teses da Universidade Estadual Paulista "Júlio de Mesquita Filho" (UNESP). A pesquisa nos catálogos foi feita utilizando-se como elemento de busca as expressões: "aluno de Pedagogia"; "perfil socioeconômico Pedagogia" e "perfil cultural Pedagogia". Além desses termos, foi realizada uma revisão utilizando-se também da palavra-chave "representação aluno Pedagogia" e variações, tendo em vista a ampliação das oportunidades de localização de pesquisas com temas afins.

${ }^{3}$ Souza, Antonio Carlos de. Os significados de ser e formar-se professor: saberes mobilizados na formação em um curso de Pedagogia, tese de doutorado, PUC-SP, 2010.

${ }^{4}$ Braz, Anádja Marilda Gomes. Teorias implícitas dos estudantes de Pedagogia sobre a docência nos anos iniciais do ensino fundamental, tese de doutorado, UFRN, 2006.
} 
também se fez presente, mas de forma não tão significativa. Esse resultado foi entendido pela pesquisadora como um efeito positivo do processo de profissionalização da atividade docente, agindo sobre a formação dos estudantes.

O modo como os estudantes de Pedagogia pensam o trabalho docente também foi investigado por Petters (2009) $)^{5}$, ao mesmo tempo que os alunos tiveram de posicionar-se a respeito de sua relação com a família e com a educação. Tais posicionamentos foram tomados neste estudo como exemplares do processo de constituição identitária dos jovens universitários, objeto de estudo da pesquisa. No que se refere ao trabalho e experiência educacional, a autora constatou que os jovens demonstraram certo "desencanto" com a formação no curso de Pedagogia pela falta de sentido entre as aprendizagens e situações da prática profisssional, ao mesmo tempo em que comentam a falta de valorização da sociedade pelo trabalho docente, apesar de depositarem suas expectativas na formação universitária como forma de realização pessoal. Em outra pesquisa também voltada para a investigação da construção identitária do pedagogo, Souza $\left(2009\right.$, p.11) ${ }^{6}$ realizou um estudo de caso com seis alunos do curso de Pedagogia da Universidade Estadual do Sudoeste da Bahia, procurando investigar o processo de escolha profissional, cujas análises foram guiadas pela psicologia analítica. Estes alunos foram selecionados para que a autora compreendesse, em suas palavras, "as motivações que levaram esses estudantes a iniciar o curso sem o desejo de serem professores ou pedagogos." Ou seja, nestes dois estudos a discussão da escolha profissional foi vinculada ao interesse em estudar a constituição da identidade de jovens universitários que frequentam o curso de Pedagogia.

Os comentários dos estudantes a respeito da desvalorização social do trabalho docente, tal como emergiram na pesquisa de Petters (2009), também foram identificados em pesquisa desenvolvida por Brandão $(2012)^{7}$, dedicada à análise das representações sociais dos alunos do curso de Pedagogia da Universidade Federal do Sergipe (UFS). Entre os objetivos da pesquisa também estavam presentes o estudo da escolha profissional, a satisfação dos mesmos com a opção realizada e as perspectivas destes estudantes quanto ao futuro exercício da profissão. Desenvolvida no âmbito da psicologia social, a pesquisa utilizou como referencial teórico para

\footnotetext{
${ }^{5}$ Petters, Luciane Carmem Figueredo. Trajetórias e expectativas de jovens universitários: um estudo sobre os processos identitários dos jovens do curso de Pedagogia na relação educação, trabalho e ações coletivas, dissertação de mestrado, UNIVALI, 2009.

${ }^{6}$ Souza, Sandra Suely de Oliveira. Construção identitária do pedagogo em formação: elementos simbólicos constelados na incerteza da escolha profissional, dissertação de mestrado, UFBA, 2009.

${ }^{7}$ Brandão, Denise Freitas. Você quer ser professor? Um estudo sobre o interesse de licenciandos em Pedagogia pela profissão docente, dissertação de mestrado, UFS, 2012.
} 
a discussão das representações sociais o pensamento de Moscovici, além das contribuições da psicologia do trabalho. Dentre os resultados da pesquisa destaca-se que os alunos reconhecem a importância do trabalho do professor, embora alguns tenham expressado sua insatisfação com a escolha realizada por fatores ligados à desvalorização social, remuneração e jornada de trabalho. Os alunos investigados ainda indicaram o desejo de trabalharem como professores, porém, por um curto período de tempo, sendo que os alunos detentores de maior interesse pela profissão são justamente aqueles mais satisfeitos com a escolha profissional realizada e que perceberam de modo positivo eventuais experiências vivenciadas na função de professor.

Assim como a pesquisa de Brandão (2012) interessou-se pelo estudo da escolha e do projeto profissional dos alunos de Pedagogia, as investigações desenvolvidas por Diniz (2010)8, Oliveira (2001)9, Souza (2009), Souza, L. O. (2010)10 e Leme (2012)11 também se aproximam das questões que mobilizam o desenvolvimento da pesquisa aqui apresentada. Contudo, tais estudos se afastam da proposta aqui desenvolvida, no que se refere à opção metodológica e referencial teórico utilizados para a elaboração das análises. Nos trabalhos acima indicados as investigações partiram do estudo de apenas uma única instituição de ensino, com exceção da pesquisa desenvolvida por Oliveira (2001), que propôs o estudo de duas instituições particulares e Souza, L. O. (2010) que investigou uma instituição particular e outra pública.

Apesar da perspectiva comparativa, a pesquisa de Oliveira (2001, p. 64) não assumiu a preocupação de investigar alunos vinculados a instituições significativamente distintas, tendo em vista a diversificação de suas origens sociais e histórico de formação, já que as duas instituições participantes da análise são particulares e "Suas mensalidades referentes ao curso de Pedagogia são similares, assim como suas instalações e recursos instrucionais". Além disso, não houve preocupação em realizar um estudo aprofundado do perfil sociocultural e econômico dos alunos. Por sua vez, a pesquisa elaborada por Souza, L. O. (2010) estudou duas instituições distintas - a Pontifícia Universidade Católica de São Paulo (PUC-SP) e a Universidade Federal do Mato Grosso, entretanto a perspectiva utilizada foi a de promover uma comparação entre os

\footnotetext{
${ }^{8}$ Diniz, Maria de Fátima Chagas. O(a) acadêmico(a) do curso de Pedagogia e suas expectativas profissionais no século XXI: Um estudo com os alunos(as) do Curso de Pedagogia 2006/2009 da Faculdade Padrão do Município de Goiânia-Goiás, dissertação de mestrado, PUC/Goiânia, 2010.

${ }^{9}$ Oliveira, Luciana Rodrigues. Estudo do projeto de vida profissional de alunos universitários do curso de Pedagogia, dissertação de mestrado, UNICAMP, 2001.

${ }^{10}$ Souza, Levi de Oliveira. Motivações para a escolha da Licenciatura em Matemática e Pedagogia: um estudo com alunos da PUC/SP e UFMT, dissertação de mestrado, PUC/SP, 2010.

${ }^{11}$ Leme, Luciana França. Atratividade do magistério para o ensino básico: estudo com ingressantes de cursos superiores da Universidade de São Paulo, dissertação de mestrado, FEUSP, 2012.
} 
alunos do curso de Pedagogia e os de licenciatura em Matemática, tendo em vista discutir a escolha da carreira docente e sua atratividade. Do mesmo modo que Souza, L. O. (2010, p. 17) constatou que "cada vez menos estudantes escolhem a carreira de professor de matemática", Leme (2012) interessou-se por analisar a atratividade do magistério para o ensino básico entre alunos ingressantes dos cursos de Pedagogia, Física e Matemática da Universidade de São Paulo. Ao mesmo tempo, a autora investigou se alunos do curso de Medicina da mesma instituição já tiveram algum dia o interesse em atuar como professores da educação básica. Nesta pesquisa o nível socioeconômico dos alunos foi investigado, assim como o aproveitamento dos mesmos no exame vestibular, bem como os fatores que contribuem ou não com a decisão de atuar no âmbito do magistério.

Pesquisas centradas no estudo de alunos vinculados a uma mesma instituição de ensino superior foram elaboradas por Diniz (2010) e Gomes (2007) ${ }^{12}$. No caso desta última, a autora comparou o nível de formação dos alunos do curso de Pedagogia da Universidade Federal do Espírito Santo em suas duas modalidades: presencial e a distância. A intenção era verificar qual das duas modalidades formativas agia de forma mais eficiente no preparo profissional do pedagogo. Nesta pesquisa a condição econômica e cultural dos alunos foi investigada, entendendo que estes fatores poderiam influenciar o aproveitamento dos alunos na avaliação de rendimento realizada. Um breve estudo do perfil socioeconômico dos alunos do curso de Pedagogia também foi elaborado por Diniz (2010). Neste caso, o estudo abrangeu uma única faculdade particular de Goiânia, a fim de caracterizar os alunos que optaram pelo curso de Pedagogia, além de procurar conhecer suas expectativas profissionais. Cabe destacar que o estudo do perfil socioeconômico e cultural elaborado por estas pesquisas não foi produzido com a perspectiva desta investigação, qual seja o de relacionar a posição de classe do agente às suas formas de pensar e agir.

O estudo das pesquisas localizadas a partir do levantamento bibliográfico permitiu a identificação de trabalhos cujos temas se aproximam dos interesses desta pesquisa, entretanto, a caracterização dos mesmos favoreceu a constatação de que não existe nenhum estudo que investigou o perfil dos formandos de Pedagogia nas perspectivas social, econômica e cultural e suas representações sobre a profissão, de forma conjunta e comparativa entre instituições de diferentes perfis - públicas e particulares, tal como se propõe nesta pesquisa. Dentre os trabalhos

12 Gomes, Isabel Cristina Rabelo. Formação de professores de $\mathbf{1}^{\mathrm{a}}$ a $\mathbf{4}^{\mathrm{a}}$ série do ensino fundamental nas modalidades a distância e presencial: um estudo na Universidade Federal do Espírito Santo, tese de doutorado, UFMG, 2007. 
localizados notou-se o interesse recorrente por identificar a escolha do curso, as expectativas profissionais dos alunos de Pedagogia e o interesse dos mesmos pela docência, entretanto, nesta pesquisa, a análise dos modos de agir e pensar dos agentes serão observadas de modo associado ao estudo da origem social das diferentes frações de classe distribuídas em cada uma das instituições universitárias aqui em estudo. A investigação de formandos relacionados a instituições distintas, capazes de atrair alunos com perfis socioeconômicos e culturais diversos, favorecerá a relação que se pretende estabelecer entre o habitus, na perspectiva elaborada por Pierre Bourdieu, e a escolha do curso de Pedagogia, a decisão de ingresso em uma dada instituição universitária, bem como os planos formativos, profissionais e representações sobre a profissão.

Nas reflexões elaboradas por Pierre Bourdieu no capítulo "O espaço dos pontos de vista", presente na obra A Miséria do Mundo (2008), as formas de pensamento e de interpretação da realidade formuladas pelos agentes são constituídas no interior de um espaço social que age sobre os mesmos, contribuindo na configuração da maneira de se relacionar e explicar o mundo. As formas de compreensão e ação no espaço social não são iguais para todas as pessoas, uma vez que o pertencimento do indivíduo a uma determinada classe social, a uma etnia ou até mesmo a uma determinada geração, o realoca em um ponto diferenciado desse mesmo espaço social. A multiplicidade de posições que podem ser ocupadas no espaço social impõe a necessidade de compreender o mundo sob diferentes perspectivas, evitando-se que o pesquisador limite sua análise a um ponto de vista único, redutor de uma realidade que é complexa e múltipla. Ao tomar como objeto de estudo imigrantes, nativos, jovens, adultos, operários, artesãos, Bourdieu demonstra seu esforço em compreender a pluralidade de perspectivas existentes, na busca pela da apreensão dos modos como o espaço social é estruturado.

No espaço social as relações entre os seres humanos são demarcadas essencialmente pela diferença que se relaciona com a distribuição das formas de poder ou com a posse dos capitais mais significativos no universo social. Considerando-se o capital econômico e o capital cultural como os capitais mais eficientes no posicionamento do indivíduo no interior do espaço social, Bourdieu (1996) afirma que os agentes estão mais próximos hierarquicamente, quanto mais estes dois capitais se aproximam. Por outro lado, considerando-se a posse do poder, o espaço social caracteriza-se como um local de disputas entre agentes que se enfrentam, de modos diferenciados, de acordo com a posição ocupada no campo. As vitórias experimentadas pelos agentes em disputa terminam por conservar ou transformar a estrutura social na qual os 
embates se dão, uma vez que a modalidade de campo em questão é o campo do poder: "entendendo por tal as relações de forças entre as posições sociais que garantem aos seus ocupantes um quantum suficiente de força social - ou de capital - de modo a que estes tenham a possibilidade de entrar nas lutas pelo monopólio do poder (...)" (BOURDIEU, 2010, p.28).

Os conflitos travados entre os agentes sociais, no interior do campo, são lutas simbólicas, disputadas nas relações cotidianas mais comuns entre os indivíduos, estando presente nas maneiras de cumprimentar, na forma de dirigir o olhar ao outro, no reconhecimento de um título, nas tentativas de conquistar uma vaga de trabalho, entre outras situações. Dissimulada, essa luta não deixa de ser permanente ou eficaz, e tem relação com as posições ocupadas pelos agentes no espaço social. Além de estarem presentes nas relações diárias, nas situações mais minuciosas, as lutas simbólicas visam a demarcar o mundo social a partir dos interesses dos agentes sociais, impondo as ideologias arbitrariamente, mas que agem sobre o outro sem que necessariamente se dê a percepção da imposição:

O poder simbólico como poder de constituir o dado pela enunciação, de fazer ver e fazer crer, de confirmar ou de transformar a visão do mundo e, deste modo, a acção sobre o mundo, portanto o mundo; poder quase mágico que permite obter o equivalente daquilo que é obtido pela força (física ou econômica), graças ao efeito específico de mobilização, só se exerce se for reconhecido, quer dizer, ignorado como arbitrário (Bourdieu, 2010, p.14).

Dessa forma, a ordem estabelecida passa a ser vivenciada com naturalidade, visto que é compreendida como legítima. A manutenção da ordem social, por meio do exercício da dominação, se impõe pela ação ideológica, fazendo com que os indivíduos assumam como interesse universal, aquilo que na verdade é útil a apenas um grupo: a classe dominante. Nesta circunstância as hierarquias e distinções são legitimadas, enquanto as classes dominadas são assim definidas pela distância que as afasta da cultura dominante (Bourdieu, 2010).

A ordenação do mundo social é, portanto, produzida por meio da percepção dos próprios agentes sociais, os quais disputam no interior da luta de classes, o domínio do poder em modificar e impor as categorias de compreensão do mundo. Trata-se de uma luta simbólica em que se deseja impor aos demais, representações sobre o espaço social que sejam vantajosas para o grupo que o agente social pertence, ao produzir para si um capital simbólico de reconhecimento.

Ao discutir o trabalho realizado por especialistas na configuração de uma nova categoria para o termo região, Bourdieu (1996) observa que as representações de origem científica são capazes de produzir na realidade aquilo que foi descrito ou designado conceitualmente pela própria ciência. O poder em definir as classificações, ou seja, em produzir 
as representações, disputado no interior do campo científico, será tão mais eficiente quando a oposição entre representação e realidade for superada: "(..) a ciência deve (...) incluir no real e representação do real (...) modificar as representações mentais" (p.108). Nesta perspectiva, a ciência age tão poderosamente, que é capaz de produzir, por meio das representações criadas, a própria realidade, criar ou desfazer grupos e até mesmo agir sobre a identidade dos indivíduos.

Bourdieu (1996) indica que a noção de região não se relaciona com o que os geógrafos pensam definir a partir de observações objetivas da realidade natural, mas resulta sim, de uma fala expressa por uma autoridade científica - o auctor, cujo discurso é reconhecido e legitimado, e termina por dividir o mundo social criando representações objetais que são impostas e, ao mesmo tempo, aceitas e incorporadas como representações mentais pelos agentes sociais. A ciência é capaz de, por meio de um discurso performativo, criar a realidade como construção social, fruto da ação dos auctores e representativa do exercício do poder de impor visões e formas de ordenamento do mundo social, que terminam por se materializar na instituição da realidade.

A forma como a representação dominante sobre o conceito de região afeta a identidade dos indivíduos, relaciona-se com a compreensão destes de que seu valor como pessoa está vinculado ao reconhecimento da identidade social do grupo no qual está inserido, abrangendo aí seu valor simbólico. Quando na condição de dominado, no interior das relações de forças simbólicas, a identidade do agente social passa por um processo de apropriação da identidade entendida como legítima e, ao mesmo tempo, dá-se o abandono das características que o estigmatizam e o afastam do reconhecimento no grupo social legitimado, tem-se a expressão da violência simbólica que age sobre o indivíduo (Bourdieu, 2010). Mesmo que o agente social concorde de modo voluntário e livre em promover tal adequação na sua identidade, desejando se apropriar das vantagens associadas à posse de uma identidade legítima, a violência simbólica não deixou de agir. Por outro lado, assumir de modo não consciente a legitimidade da dominação, pela incorporação da estrutura social na estrutura mental, de modo que o dominado possua a mesma percepção dos dominantes sobre a hierarquia e ordem social, expressa a ação da violência simbólica já presente na própria configuração do habitus. A manutenção da ordem social, vinculada à conservação da ordem simbólica, relaciona-se, portanto, com a concordância entre a estrutura social e sua incorporação no habitus dos indivíduos (Champagne, 2008).

Há, portanto, uma associação entre as noções de campo e habitus, uma vez que a estrutura do campo vincula-se à gênese das estruturas mentais, uma vez que estas são, em parte, a apropriação das estruturas sociais. Ao mesmo tempo, as estruturas mentais engendram o 
próprio espaço social e a hierarquização dos grupos que nele se encontram, sendo este processo fruto de disputas dos interesses dos agentes que se movimentam no campo em função de suas representações e posição no espaço social (BOURDIEU, 2004).

O conceito de habitus em Bourdieu resulta da tentativa do autor em superar a contradição entre objetivismo e subjetivismo como fontes da ação e da percepção do mundo social pelo indivíduo. Na perspectiva objetivista, a ação humana é resultado direto das condições externas, enquanto na perspectiva subjetivista o indivíduo é completamente livre e consciente de seu atos. Nem totalmente passivo aos agentes externos, nem totalmente liberto dos mesmos, o homem tem sua percepção e ação sobre o mundo guiadas por aquilo que foi incorporado de modo consciente e inconsciente do mundo social. Por este motivo, Champagne (2008) afirma que a noção de habitus permite compreender que os comportamentos são prováveis, visto que o homem é afetado pelo mundo social, e ao mesmo tempo, jamais totalmente previsíveis pelo fato dos corpos não obedecerem mecanicamente aos ditames da consciência. O habitus, expresso inconscientemente no corpo, pela hexis, também participa dos modos de compreensão do mundo. Trata-se de uma disposição adquirida e que age no nível prático afetando as "categorias de percepção e apreciação", as formas de classificar e agir.

O habitus, fruto da condição social de origem dos agentes, gera determinadas práticas e formas de pensar o mundo (julgamentos, percepções, costumes) e delimita um determinado estilo de vida, ou seja, ações que são reconhecidas como pertencentes a uma dada classe social: "Os habitus são princípios geradores de práticas distintas e distintivas - o que o operário come, e sobretudo sua maneira de comer, o esporte que pratica e sua maneira de praticá-lo" (Bourdieu, 1996, p.22). As diferenças expressas nas práticas, na posse de bens e no modo de pensar tornamse diferenças simbólicas, sendo o habitus de cada indivíduo, o elemento que comunica o grupo de pertencimento social do agente.

Entendendo que as práticas e as formas de pensar o mundo variam de acordo com o habitus do agente, esta pesquisa objetiva conhecer a origem socioeconômica e cultural dos alunos investigados e verificar a existência de uma correspondência entre a mesma e a inserção dos mesmos em uma dada universidade; os modos de escolha profissional; suas práticas de lazer; suas expectativas profissionais e formativas após o encerramento do curso e, por fim, suas representações sobre a profissão e o trabalho docente. Assim, a escolha de quatro instituições distintas, cujas especificidades atraem alunos ocupantes de posições diversas no espaço social, permitirá a observação de eventuais variações existentes entre estes diferentes grupos de estudantes. 
Assim, a escolha das instituições foi feita a partir da preocupação em investigar alunos com diferentes perfis, vinculados a universidades com características diversas, tais como histórico de criação, princípios formativos, tempo de funcionamento e tradicionalismo, estratégia de seleção dos alunos ingressantes, localização, nível de abrangência no espaço acadêmico e valor da mensalidade, no caso das instituições particulares. A partir destes critérios foram selecionadas para participar desta pesquisa as seguintes instituições: Faculdade de Educação da Universidade de São Paulo (FEUSP), Universidade Federal de São Paulo (UNIFESP), Pontifícia Universidade Católica de São Paulo (PUC-SP) e Universidade Bandeirante Anhanguera (UNIBAN-Anhanguera), campus Morumbi. A perspectiva adotada neste estudo é a de que a diversidade das instituições seja também acompanhada da diversificação do perfil de seus alunos, tendo em vista a ocupação pelos mesmos de posições variadas na estrutura social. Reconhecendo que as representações variam de acordo com os diferentes grupos sociais, a diversificação das instituições é tomada aqui como estratégia metodológica fundamental para que se seja possível conhecer as representações dos alunos, a partir de diferentes pontos de vista, considerando-se a multiplicidade de posições ocupadas por estes agentes no espaço social (Bourdieu, 2008).

A investigação dos estudantes, por sua vez, ocorreu por meio da aplicação de um questionário $^{13}$ que pretendeu delinear quem são os formandos do curso de Pedagogia. Desse modo, a decisão pelos alunos do último ano do curso de Pedagogia é justificada pelo fato dos mesmos terem uma experiência formativa mais consolidada, favorecendo assim sua capacidade de responderem de modo mais consistente as perguntas que lhes foram dirigidas ao longo da investigação. As perguntas apresentadas aos alunos procuravam investigar o perfil socioeconômico e cultural dos estudantes, além de ter por intenção conhecer: a trajetória de formação escolar; as experiências profissionais; as condições de ingresso no ensino superior; a escolha e as expectativas profissionais e, por fim, as representações sobre o trabalho docente.

O questionário foi elaborado por meio do uso de uma ferramenta denominada SurveyMonkey que permite a disponibilização das perguntas e recolha dos dados dos participantes via web. Após a criação do questionário e disponibilização do mesmo na plataforma do SurveyMonkey, as respostas foram obtidas por meio do acesso dos respondentes ao endereço de internet gerado. Dividido em dez partes, as perguntas do questionário foram organizadas em temas, os quais são apresentados a seguir:

${ }^{13} \mathrm{O}$ questionário utilizado está disponível no anexo desta tese. 
1. Identificação: neste item as perguntas procuravam identificar o sexo; a idade; a raça; o estado civil e o número de filhos do respondente.

2. Trajetória escolar: neste tópico do questionário as perguntas indagavam sobre o tipo de escola frequentada pelo estudante durante o ensino fundamental e médio; o Estado em que o ensino médio foi concluído; qual foi a modalidade do ensino médio cursado; em que período o ensino médio foi frequentado; qual foi jornada de trabalho durante os estudos; se houve a frequência a algum cursinho pré-vestibular; qual foi o intervalo existente entre a conclusão do ensino médio e o ingresso no ensino superior e, por fim, se algum outro curso superior já havia sido iniciado e/ou concluído anteriormente.

3. Dimensão sociocultural familiar - o objetivo das questões apresentadas neste item era conhecer o nível de escolaridade e atividades profissionais desempenhadas pelos pais dos estudantes investigados.

4. Características socioeconômicas - neste tópico do questionário objetivou-se investigar a faixa de renda individual e familiar; o número de pessoas sustentadas com a renda declarada; as condições de moradia - casa própria ou alugada; as condições atuais de trabalho do estudante - atividade profissional desempenhada, jornada e remuneração e, por fim, o turno em que cursou a maior parte da graduação em Pedagogia.

5. Condições de ingresso no ensino superior - por meio das perguntas apresentadas neste item, procurou-se saber se os alunos das instituições particulares contaram com algum tipo de financiamento ou bolsa de estudos para custear as mensalidades do curso e se o estudante foi beneficiado na ocasião do seu ingresso, por alguma política de ação afirmativa.

6. Moradia, acessibilidade e transporte - este grupo de questões teve por objetivo conhecer o local de moradia do aluno, o tempo gasto e o meio de transporte utilizado para chegar à universidade.

7. Estágio - o objetivo das questões apresentadas neste item era conhecer o tipo de estágio realizado pelos alunos e quais impressões a experiência do estágio gerou nos estudantes.

8. Escolha e expectativas profissionais - as questões apresentadas neste item pretenderam identificar se o curso de Pedagogia foi a primeira opção de formação profissional dos alunos, além de procurar conhecer os argumentos que motivaram a realização dessa escolha e, por fim, se a mesma contou com o apoio familiar. Além disso, as outras questões investigaram a percepção dos alunos sobre o curso realizado: quais disciplinas mais contribuíram com o processo formativo vivenciado na universidade; quais os principais aprendizados adquiridos e as maiores dificuldades enfrentadas durante a formação no ensino superior. Por fim, procurouse conhecer quais os planos profissionais dos alunos após a conclusão do curso.

9. Hábitos culturais - as questões apresentadas neste tópico do questionário destinaram-se a conhecer como se dá o uso do tempo livre e quais são as práticas culturais dos estudantes investigados.

10. Questões gerais - por fim, o último conjunto de questões procurou conhecer as representações dos formandos sobre o trabalho e a profissão docente, bem como os princípios éticos e o posicionamento político dos alunos investigados. 
Ao ser finalizado, o questionário contava com oitenta questões, das quais sessenta e nove eram objetivas e vinte e uma dissertativas. Antes de ser aplicado com os alunos investigados, o questionário passou por um pré-teste com uma pequena população que evidenciou a necessidade de adequações e, ainda, permitiu que fosse conhecida a média de tempo necessária para que o mesmo fosse respondido, considerando-se a sua extensão e nível de complexidade.

O levantamento realizado na UNIBAN - Anhanguera campus Morumbi ocorreu no mês de junho de 2013. Nesse ano o curso de Pedagogia do campus Morumbi contava com apenas uma turma com vinte e duas alunas que frequentavam o último ano do curso no período noturno. No dia do levantamento havia vinte alunas presentes e todas responderam ao questionário no próprio laboratório de informática da instituição. Após o encerramento do ano letivo, o número de alunas que concluíram a graduação foi de vinte estudantes. Desse modo, a representação deste grupo nesta investigação foi significativamente elevada.

O próximo levantamento ocorreu na UNIFESP de Guarulhos nos meses de julho e agosto de 2013. Com a indicação da coordenação do curso, pude comparecer nas aulas das disciplinas de Metodologia da Pesquisa no Campo da Educação, destinada à formação teórica e prática dos alunos, visando à capacitação dos mesmos para o processo de elaboração do trabalho de conclusão de curso, obrigatório nesta instituição para os alunos concluintes. Pela impossibilidade de utilizar o laboratório de informática do campus, no dia do contato com as turmas, foi realizada a apresentação da pesquisa e o convite para que os alunos respondessem ao questionário via internet.

Diante de um universo de sessenta e oito potenciais alunos colaboradores (sendo este o total de alunos matriculados na disciplina nos períodos vespertino e noturno), a pesquisa contou com quarenta e duas participações espontâneas, atingindo um total de $61,76 \%$ de representatividade dos formandos da UNIFESP. Procurando ampliar a representatividade do grupo de alunos da UNIFESP na pesquisa, foi tomada a decisão de imprimir alguns questionários e solicitar o preenchimento manual dos mesmos. A partir desse esforço, foram obtidas outras catorze novas contribuições, cujas respostas foram transcritas para o questionário online posteriormente. Considerando as participações online e o preenchimento manual do questionário, obteve-se um total de 56 (cinquenta e seis) respostas, atingindo assim o número de $82,35 \%$ de representatividade dos possíveis ${ }^{14}$ formandos da UNIFESP. Chamou a atenção,

${ }^{14}$ Como a matrícula dos alunos nesta instituição não ocorre por "blocos de disciplinas" institucionalmente definidas, mas a partir da escolha do estudante, responsável pela definição do seu próprio percurso formativo, 
porém, o número de alunas deste curso que efetivamente concluíram sua graduação após o encerramento do ano letivo de 2013 (efetivado em março de 2014). De acordo com os dados disponibilizados pela área técnica em assuntos educacionais da unidade, o número de concluintes foi de somente vinte e sete estudantes.

O terceiro levantamento foi realizado na Faculdade de Educação da USP no mês de agosto de 2013. Procurando abranger o maior número possível de formandos, foi obtida uma autorização da Comissão de Coordenação do Curso de Pedagogia (CoC Pedagogia) para divulgar a pesquisa por meio da seção de alunos da FEUSP, que encaminhou para a caixa de mensagem de todos os alunos matriculados, um email que apresentava a pesquisa e convidava os formandos a participarem da mesma, bastando para isso clicar sobre o link que dava acesso ao questionário via web. Com esse procedimento foi obtida a participação voluntária e inicial de setenta e cinco alunos. Do mesmo modo como se passou na UNIFESP, apesar no número de potenciais formandos da FEUSP ser elevado, de acordo com a seção de alunos da universidade o número de estudantes que colaram grau e solicitaram seu diploma no final do ano de 2013 foi de trinta e cinco alunos.

O último levantamento ocorreu no mês de setembro de 2013 na PUC-SP. Com a autorização da coordenação e indicação das docentes que ministravam aulas para as turmas de último ano, a pesquisa ocorreu em dois dias de visita, nas turmas do período matutino e noturno. No período da manhã, a turma de formandos era composta por 12 (doze) alunas frequentes e no dia da intervenção havia 9 (nove) estudantes na sala de aula. Após a apresentação dos objetivos da pesquisa e da realização do convite, seis alunos responderam ao questionário impresso, enquanto três responderam online. No período noturno, a turma de formandos era composta por vinte e cinco alunos frequentes. No dia da investigação dezoito alunos estavam na sala de aula e todos responderam ao questionário impresso.

Considerando os alunos frequentes nas listas de presença, tanto no período matutino, quanto noturno, presumiu-se que o total de formandos da PUC-SP em 2013 era de aproximadamente 38 (trinta e oito) estudantes. Destes, 27 participaram da investigação, perfazendo um total de $71 \%$ de representatividade do grupo investigado. Contudo, de acordo com as atas de colação de grau da universidade, no ano de 2013 a PUC-SP formou um total de 52 estudantes no curso de Pedagogia.

estabeleceu-se uma certa dificuldade em saber exatamente o número de alunos que estavam de fato no último ano do curso nesta instituição, fenômeno que se repetiu na Faculdade de Educação da USP. 
A intenção de contar com a participação do maior número de formandos em cada uma das quatro instituições guiou efetivamente os modos como o levantamento de dados foi realizado. Ainda assim, ocorreram discrepâncias entre o número de respondentes envolvidos na pesquisa e a quantidade de formandos efetivos em cada uma das universidades. Alguns fatores podem ter contribuído na constituição desse quadro. Nas universidades públicas a flexibilidade do currículo dificultou a localização física dos formandos em sala de aula, apesar do encaminhamento realizado na UNIFESP de contatar os estudantes que frequentavam a disciplina de orientação para a elaboração do TCC, acompanhamento que se dá, na maior parte das vezes, por alunos que estão de fato encerrando seu processo formativo. No caso da FEUSP, a mensagem encaminhada pela seção de alunos aos cursistas, enfatizava a colaboração estrita dos últimos anistas. Nessas duas instituições, parte dos respondentes poderiam de fato estar no último ano de sua formação e ter, por inúmeras razões, protelado a conclusão do curso para o semestre seguinte. Por fim, na PUC-SP, o contato autorizado pela coordenação do curso com as duas turmas de último ano pode não ter sido suficiente para que todos os eventuais formandos fossem de fato localizados ${ }^{15}$.

Convém mencionar que o número de participantes não se manteve estável ao longo de todo o questionário. Alguns alunos abandonaram a pesquisa antes mesmo de concluí-la. Esta situação ocorreu entre os alunos da FEUSP e UNIFESP, cuja participação inicial foi de 75 e 56 alunos, respectivamente, caindo para 53 e 51 respondentes ao término do questionário. $\mathrm{Na}$ UNIBAN-Anhanguera, o número e respondentes se manteve estável ao longo de toda a pesquisa, enquanto na PUC-SP ocorreram duas desistências.

Os dados obtidos por meio da participação dos respondentes foram acumulados em uma plataforma online denominada SurveyMonkey. O acesso às informações armazenadas deuse por meio do download dos mesmos, agora apresentados em uma planilha do excel. Esta planilha, entretanto, não permitia a realização imediata da análise estatística, já que na base de dados originalmente gerada pelo SurveyMonkey, cada uma das alternativas oferecidas nas questões de múltipla escolha, correspondeu a uma coluna da tabela. Assim, na base de dados bruta, as respostas dos alunos investigados foram distribuídas em uma planilha detentora de 400 colunas de informações prestadas pelos alunos investigados. Todo esse volume de dados exigiu um processo de criação de categorias internas para as respostas de cada uma das

${ }^{15} \mathrm{O}$ endereço eletrônico dos formandos foi solicitado nesta instituição, tendo em vista o encaminhamento do questionário aos mesmos, porém a Universidade não disponibiliza dados pessoais dos seus alunos ao público externo. 
perguntas, visando ao agrupamento de informações para que os resultados assumissem um significado analítico, impossível de ser obtido diante de respostas excessivamente dispersas.

Após a realização do trabalho de organização e categorização das informações contidas no banco de dados, de modo a permitir a identificação da recorrência das respostas, duas estratégias foram implementadas tendo por objetivo o cruzamento da informações reunidas. Em um primeiro momento foi solicitado ao Centro de Estatística Aplicada (CEA) do Instituto de Matemática e Estatística da USP, a realização do tratamento estatístico dos dados, tendo em vista identificar as associações que caracterizariam os respondentes investigados em cada uma das quatro instituições. Simultaneamente e, visando ao alcance do mesmo objetivo, foi realizado um trabalho de cruzamento dos dados por meio da utilização do recurso "tabela dinâmica" do excel.

Em ambas estratégias, não foram desconsideradas as respostas dos participantes que deixaram o questionário incompleto. Assim, nas situações de contribuição parcial, todos os registros foram utilizados, enquanto as perguntas deixadas em branco foram desconsideradas da soma final. Consequentemente, serão observadas ao longo da pesquisa flutuações no volume de respostas para as diferentes questões abordadas. Tal especificidade fez com que cada uma das tabelas fossem analisadas considerando-se a proporção total de colaboradores para cada uma das perguntas em estudo.

Quanto ao trabalho desempenhado pelo CEA, foram realizados testes para indicar a existência ou não de associação entre as variáveis analisadas. Para tabelas preenchidas com observações suficientes em cada casela, foram feitos testes qui-quadrado. Caso contrário, foi utilizado o teste exato de Fisher. Vale ressaltar que colunas e/ou linhas totalmente zeradas foram agrupadas a outras categorias; no entanto, como havia tabelas com muitas categorias, alguns valores foram obtidos por meio de simulações.

Os testes foram feitos através da diferença entre as frequências observadas em cada categoria e as frequências esperadas no caso das variáveis serem independentes, sendo possível encontrar um valor que indica o nível descritivo do teste. Assim, os valores abaixo de 10\% indicaram a existência de associação entre as variáveis. No caso das tabelas que apresentam aparente relação entre as variáveis, foi calculado o coeficiente de associação, a fim de verificar a existência de dados fortemente relacionados. Os resultados produzidos por meio do recurso "tabela dinâmica" do excel e aqueles fruto de análise estatística, são apresentados ao longo de todos os capítulos desta investigação. 
Esta tese está organizada em seis capítulos. O primeiro capítulo intitulado "O curso de Pedagogia, a expansão do ensino superior no Brasil e as especificidades das instituições investigadas" aborda as expectativas existentes em torno da necessidade do professor de ensino fundamental ser detentor de formação universitária; apresenta um mapeamento dos cursos de Pedagogia atualmente em atividade no estado e município de São Paulo e, por fim, trata do processo histórico de expansão do setor público e privado, ao mesmo tempo que detalha as especificidades que particularizam cada uma das universidades envolvidas nesta pesquisa.

O segundo capítulo “"Eu quero ser professora!’ A adesão ao curso de Pedagogia e ao trabalho docente - O caso UNIBAN-Anhanguera"; o terceiro "Cursar Pedagogia na UNIFESP de Guarulhos: as expectativas de ganhos simbólicos e concretos envolvidas nesta decisão"; o quarto "A diversidade no interior de um grupo: variações socioeconômicas, culturais e de representação - o caso da PUC-SP" e o quinto capítulo "Da clareza na escolha à certeza do sentido social da profissão" (FEUSP) apresentam o perfil socioeconômico dos respondentes de cada uma das instituições; descrevem suas práticas culturais e detalham os modos como se processou a escolha profissional dos alunos, bem como seus planos profissionais e formativos, além de suas representações sobre a profissão docente.

O sexto e último capítulo teve por intenção realizar uma análise conjunta dos dados apresentados nos capítulos anteriores, identificando proximidades e distanciamentos entre os formandos envolvidos nesta pesquisa. O último item desse capítulo tratou do grupo de respondentes que mesmo estando em um curso de formação de professores, já exercia a docência e, por este motivo, nutria expectativas muito peculiares em relação ao curso, assim como planos de continuidade formativa e de atuação profissional.

Esse trabalho conta ainda com dois apêndices. O apêndice A apresenta o questionário utilizado para o levantamento de dados juntos aos formandos investigados, enquanto o apêndice B descreve o histórico de criação das instituições, seus Projetos Políticos Pedagógicos, bem como as estratégias de seleção dos alunos ingressantes. 


\section{O Curso de Pedagogia, a eXPAnsão do ensino SUPERIOR no Brasil e aS ESPECIFICIDADES DAS INSTITUIÇÕES INVESTIGADAS}

Inicialmente implementada no âmbito das Escolas Normais, a formação do antigo ensino primário - correspondente ao atual Fundamental I - foi acompanhada da ideia de que a mesma deveria se dar no âmbito do ensino superior. Os Pareceres do Conselho Federal de Educação de 1962 e 1969 apontavam nessa direção, permitindo o direito ao exercício do magistério por meio da obtenção do diploma no curso de Pedagogia. Até o ano de 1961 o curso de Pedagogia permaneceu organizado em três anos de bacharelado, com a possibilidade de obtenção da licença para o magistério, mediante a realização de mais um ano de estudo no curso de Didática. Com a Reforma Universitária de 1968, deu-se a reestruturação do curso que passou a habilitar especialistas em quatro áreas específicas: Supervisão Escolar, Orientação Educacional, Administração e Inspeção Escolar. Posteriormente, houve a inclusão de novas habilitações nas áreas em Educação Infantil e séries iniciais do Ensino Fundamental. Entre os anos de 1980 e 1990, o currículo do curso passou por reformulação, sendo o mesmo dirigido ao preparo do professor de educação infantil e séries iniciais. Este processo culminou com a publicação da Lei de Diretrizes e Bases da Educação Nacional (LDB) 9.394/96 que indicou a preferência por formar os professores da educação básica em nível superior, nos cursos de licenciatura e de graduação plena, tanto em universidades quanto nos Institutos Superiores de Educação. Os ISEs receberam a atribuição de manter cursos e programas para a formação inicial e continuada de profissionais da educação, entretanto, os mesmos concorriam com a formação ministrada pelas Universidades / Faculdades de Educação que contavam com os mesmos objetivos formativos, produzindo-se assim uma "superposição" entre o curso de Pedagogia e o curso normal superior (TANURI, 2000, p. 85).

Anteriormente ao estabelecimento da Lei 9.394/96, a formação de professores dos anos iniciais do ensino fundamental ocorria predominantemente em nível médio, porém, de acordo com o artigo 87, parágrafo $4^{\circ}$, até o final do ano de 2007 só seriam admitidos, nestes níveis de ensino, professores com habilitação em nível superior ou formados por treinamento em serviço. Em 2003, entretanto, um Parecer do Conselho Nacional de Educação (CNE) e da Câmara de Educação Básica (CEB) reconheceu que professores com formação de nível médio, na modalidade normal, possuíam o direito adquirido e constitucional de exercer o magistério 
tanto na educação infantil, quanto nas séries iniciais do ensino fundamental. Em 2009, tramitava no Congresso Nacional o projeto de Lei 5.395/09, que previa a admissão de professores com formação mínima na modalidade normal apenas na educação infantil. Neste mesmo ano o trabalho de Gatti (2009) destacou que o maior número de docentes em serviço que estavam também estudando pertencia ao quadro da educação infantil, seguidos pelos professores do ensino fundamental. Dentre estes profissionais, a maior parte $(81,5 \%)$ frequentava cursos superiores.

Obviamente esta agitação em torno das exigências formativas dos professores de educação infantil e primeiros anos do ensino fundamental gerou um forte sentimento de insegurança entre os profissionais que haviam cursado o magistério no ensino médio, alimentando assim a busca pela complementação da formação já no ensino superior. Somente muito recentemente, a Lei 12.796/13 alterou a LDB de 1996, no que se refere às exigências de formação profissional. Esta Lei manteve a aceitação do diploma no curso normal como requisito mínimo para o exercício do magistério na Educação infantil e nos primeiros anos do Ensino Fundamental. Ao mesmo tempo, a Lei indica a preocupação em adotar mecanismos que incentivem a formação de profissionais do magistério em nível superior e políticas de formação continuada no local de trabalho ou em instituições de educação básica e superior. Esse incentivo está diretamente relacionado com os planos de carreira e progressão funcional atualmente em vigor e que terminaram impulsionando os professores a procurarem as instituições de educação superior para, de certa maneira, garantirem sua permanência no exercício da profissão, colocada em risco no ano de 1996, e ainda, contarem com os benefícios previstos com as políticas de promoção salarial e funcional existentes.

Tendo em vista a elaboração de um panorama atual da oferta do curso de Pedagogia no Brasil e, mais especificamente, no estado e município de São Paulo, foi realizado um levantamento das instituições existentes por meio da consulta aos dados da Sinopse Estatística da Educação Superior (Graduação) referente ao ano de $2012^{1}$ e também ao sistema eletrônico e-MEC ${ }^{2}$. Este último compreende o cadastro de estabelecimentos de ensino superior de todo o país, em todas as formas de organização acadêmica (Centro Universitário, Faculdade, Instituto Superior de Educação, Escola Superior e Universidade), categoria administrativa (privada sem

\footnotetext{
${ }^{1}$ Dados obtidos no portal do INEP: $<$ http://portal.inep.gov.br/superior-censosuperior-sinopse $>$. Acesso em: 28 nov. 2013.

${ }^{2}$ Fonte: https://emec.mec.gov.br/ies/
} 
fins lucrativos, privada com fins lucrativos, pública estadual, pública federal, pública municipal) e modalidade de ensino (presencial ou a distância).

Dados divulgados pelo Instituto Nacional de Estudos e Pesquisas Educacionais Anísio Teixeira (INEP), na Sinopse Estatística da Educação Superior (Graduação) referente ao ano de 2012, informam a existência no Brasil de 1.007 instituições que oferecem o curso de Pedagogia, nas modalidades presencial e a distância, sendo que 15,59\% delas são públicas e $84,40 \%$ são privadas. Diante do volume significativo destas últimas, elas terminam responsabilizando-se por formar $81,59 \%$ dos egressos. Considerando-se a modalidade de ensino dos cursos de Pedagogia oferecidos pela totalidade das instituições, os quais perfazem um total de 1.834, pode-se afirmar que a grande maioria é composta por cursos presenciais (94\%), enquanto menos de $6 \%$ deles são cursos ministrados a distância.

Conforme a Tabela 1.1, de acordo com o Relatório Técnico do Censo da Educação Superior de 2009, a Pedagogia ocupava o terceiro lugar entre os dez maiores cursos de graduação em número de matrícula, ficando atrás somente das formações em Administração de Empresas e Direito. No âmbito da educação a distância (Tabela 1.2), o curso de Pedagogia ocupava o primeiro lugar em número de matrículas, seguido por Administração de Empresas e Serviço Social. Em 2012, de acordo com a Sinopse Estatística da Educação Superior (Graduação), a mesma situação se repete: a Pedagogia ocupa o terceiro lugar entre os cursos mais procurados, enquanto na Educação a Distância foi mantida sua liderança em número de matrículas, seguida novamente pelos cursos de Administração de Empresas e Serviço Social. ${ }^{3}$

Tabela 1.1 - Volume de matrículas nos cursos presenciais mais procurados em 2009 e 2012

\begin{tabular}{lccc}
\hline Matrículas & Administração & Direito & Pedagogia \\
\hline $\mathbf{2 0 0 9}$ & 1.102 .579 & 651.730 & 573.898 \\
$\mathbf{2 0 1 2}$ & 833.042 & 737.271 & 602.998 \\
\hline
\end{tabular}

Tabela 1.2 - Volume de matrículas nos cursos a distância mais procurados em 2009 e 2012

\begin{tabular}{lccc}
\hline Matrículas & Pedagogia & Administração & Serviço Social \\
\hline $\mathbf{2 0 0 9}$ & 286.771 & 228.503 & 68.055 \\
$\mathbf{2 0 1 2}$ & 295.702 & 164.057 & 97.428 \\
\hline
\end{tabular}

\footnotetext{
${ }^{3} \mathrm{Na}$ Sinopse Estatística da Educação Superior (Graduação) referente ao ano de 2012 não há informações sobre a localização geográfica dos cursos de Pedagogia, entretanto, Leite e Lima (2010, p. 79), em levantamento realizado no ano de 2006, indicam que os cursos encontravam-se concentrados na "Região Sudeste (38,7\%), vindo em seguida as regiões Nordeste $(18,5 \%)$ e Norte $(17,1 \%) "$. Na Região Sudeste, o estado que continha o maior número de cursos era São Paulo (18,9\%), seguido por Minas Gerais $(11,4 \%)$ e Rio de Janeiro $(6,3 \%)$.
} 
De acordo com os dados disponíveis no e-MEC, existem no estado de São Paulo 507 cursos de graduação em Pedagogia. Destes, 451 são oferecidos na modalidade presencial, enquanto 56 proporcionam formação a distância. Considerando a organização acadêmica dos mesmos, 270 são ministrados em Faculdades; 126 em Universidades; 81 em Centros universitários; 24 em Institutos Superiores de Educação e 03 em Escolas Superiores.

A respeito da organização acadêmica das Instituições de Ensino Superior, as mesmas classificam-se em: a) Universidades - desenvolvem regularmente atividades de ensino, pesquisa e extensão. Contam com autonomia didático-científica e liberdade para abrir, fechar cursos e alterar a disponibilidade de vagas, sem autorização, com exceção dos cursos da área médica e jurídica; b) Centros universitários - oferecem ensino de excelência, sem a obrigatoriedade de desenvolverem atividades de pesquisa e extensão; possuem autorização para atuar em uma ou mais áreas do conhecimento, além de contarem com a mesma autonomia das universidades no que se refere à abertura e fechamento de vagas, além da possibilidade de alterar o número de disponibilidade das mesmas em seus cursos; c) Faculdades integradas - são compostas por um conjunto de instituições que atuam em mais de uma área do conhecimento, sob o mesmo regimento e comando. Desenvolvem atividades de ensino e, por vezes, pesquisa e extensão, além de dependerem de autorização do Poder executivo para a abertura de novos cursos; d) Faculdades, institutos superiores ou escolas superiores - geralmente atuam em uma área do conhecimento e dependem de autorização do Poder executivo para ampliarem sua área de atuação; e) Institutos superiores de educação - voltam-se para a formação de professores da educação básica e podem funcionar como unidades acadêmicas de Instituições de Ensino Superior já credenciadas (CATANI; OLIVEIRA, 2007).

Ao observar a modalidade administrativa dos cursos, constatou-se que 206 são oferecidos em instituições "Privadas com fins lucrativos"; 258 são oferecidos em instituições "Privadas sem fins lucrativos"4; 13 são ministrados em instituições "Públicas Municipais" (oferecidos em 10 estabelecimentos de ensino); 10 são oferecidos em organizações "Públicas Estaduais" (oferecidos por 04 universidades); 10 são cursos de órgãos "Públicos Federais" (oferecidos por 07 universidades). Por fim, 09 instituições não se enquadram em nenhuma das categorias já que estão submetidas à análise da Consultoria Jurídica do MEC. Diante dos dados verifica-se que a grande maioria dos cursos existentes no estado $(91,51 \%)$ são oferecidos em

\footnotetext{
${ }^{4}$ De acordo com a LDB/1996 as IES privadas foram divididas em com ou sem fins lucrativos. As instituições sem fins lucrativos representam as instituições comunitárias, confessionais e filantrópicas, sendo isentas do dever de realizar o pagamento de tributos.
} 
instituições privadas de ensino. Estes, por sua vez, estão concentrados em alguns estabelecimentos, tal como ilustra a Tabela 1.3:

Tabela 1.3 - Distribuição dos cursos de Pedagogia do estado de São Paulo, por instituição

\begin{tabular}{|c|c|}
\hline Instituição & $\begin{array}{c}\mathrm{N}^{0} \text { de cursos } \\
\text { oferecidos }\end{array}$ \\
\hline FACULDADE DE EDUCACÃO CIÊNCIAS EARTES DOM BOSCO DE MONTE APRAZÍVEL (FAECADOMBOSCO) & 5 \\
\hline FACULDADE DE ILHA SOLTERA(FAISA) & 5 \\
\hline UNIVERSIDADE ANHEMBI MORUMBI (UAM) & 5 \\
\hline UNIVERSIDADE ESTADUAL PAULISTA JÚLIO DE MESQUITA FILHO (UNESP) & 5 \\
\hline UNIVERSIDADEFEDERAL DE SÃO CARLOS(UFSCAR) & 5 \\
\hline UNIVERSIDADE MEIROPOLITANA DE SANTOS (UNIMES) & 5 \\
\hline CENTRO UNIVERSITÁRIO ESTÁCIO RADIAL DE SÃO PAULO - ESTÁCIO UNIRADIAL (RADIAL) & 6 \\
\hline CENTRO UNIVERSITÁRIO SALESIANO DE SÃO PAULO(UNISAL) & 6 \\
\hline FACULDADE DE EDUCAÇÃO SÃOLUÚS (FESL) & 6 \\
\hline FACULDADE SUMARÉ(ISES) & 6 \\
\hline FACULDADES INIEGRADAS TIBIRIÇÁ (FATI) & 6 \\
\hline CENTRO UNIVERSITÁRIO OEONARDO DA VINCI (UNIASSEIV) & 7 \\
\hline UNIVERSIDADE NOVE DE JULHO(UNINOVE) & 7 \\
\hline CENTRO UNIVERSITÁRIO ANHANGUERA DE SÃO PAULO & 8 \\
\hline FACULDADES INTEGRADAS MARIA IMACULADA (FIMI) & 8 \\
\hline UNIVERSIDADE BANDEIRANTE ANHANGUERA(UNIBAN) & 8 \\
\hline UNIVERSIDADEPAULISTA(UNIP) & 22 \\
\hline FACULDADE ANHANGUERA & 26 \\
\hline
\end{tabular}

Fonte: Elaborado pela autora

A elaboração da tabela acima considerou as instituições que oferecem cinco ou mais cursos de Pedagogia no estado de São Paulo. Por meio dela é possível notar a participação de duas Universidades públicas: a Universidade Estadual Paulista Júlio de Mesquita Filho (UNESP) e a Universidade Federal de São Carlos (UFSCAR). Na primeira, todos os cursos são presenciais, enquanto na UFSCAR um dos cinco cursos é oferecido na modalidade a distância. Dentre as instituições privadas é notável a participação da Universidade Paulista (UNIP) e da organização Anhanguera que se manifesta como Universidade, Faculdade e Centro Universitário, abrangendo a disponibilização de 42 cursos de Pedagogia, localizados tanto na capital, quanto no interior do estado. No caso da UNIP dos 22 cursos oferecidos, apenas um é a distância, enquanto na Anhanguera todos os cursos são presenciais.

A partir dos dados do e-MEC existe na cidade de São Paulo 147 instituições que oferecem o curso de Pedagogia. Destes, 114 são presenciais e 33 são a distância. No que se refere à organização acadêmica, as Universidades (39,45\%) são as que oferecem mais cursos, seguidas pelas Faculdades (34,01\%) e Centros universitários (24,48\%). Os Institutos Superiores de Educação, por sua vez, respondem por somente 2,04\% dos cursos. Em termos de modalidade administrativa nota-se a participação significativa das instituições privadas (97\%), destas 
23,71\% são identificadas como "privadas com fins lucrativos", enquanto 76,28\% são "privadas sem fins lucrativos". No âmbito das instituições públicas, existem dois cursos estaduais, sendo um deles oferecido pela Universidade de São Paulo (USP) e o outro pela Universidade do Tocantins (UNITINS), este último disponibilizado na modalidade a distância.

As instituições na cidade de São Paulo que se destacam no oferecimento de cursos são indicadas na Tabela 1.4:

\section{Tabela 1.4 - Distribuição dos cursos de Pedagogia da cidade de São Paulo, por instituição}

\begin{tabular}{lc}
\hline Instituição & $\begin{array}{c}\mathbf{N}^{0} \text { de cursos } \\
\text { oferecidos }\end{array}$ \\
\hline CENTROUNIVERSITÁRIO ESTÁCIO RADIAL DE SÃO PAULO - ESTÁCIO UNIRADIAL (RADIAL) & 6 \\
FACULDADE SUMARÉ(ISES) & 6 \\
FACULDADES INTEGRADAS TIBIRIÇÁ(FATI) & 6 \\
UNIVERSIDADE BANDEIRANTE ANHANGUERA(UNIBAN) & 6 \\
UNIVERSIDADE NOVE DE JULHO(UNINOVE) & 7 \\
CENTROUNIVERSITÁRIO ANHANGUERADE SÃOPAULO & 8 \\
UNIVERSIDADEPAULISTA(UNIP) & 9 \\
\hline
\end{tabular}

Fonte: Elaborado pela autora

A elaboração da tabela acima considerou as instituições que oferecem cinco ou mais cursos de Pedagogia na cidade de São Paulo e por meio dela é possível notar mais uma vez a significativa participação da organização Anhanguera Educacional, assim como ocorreu no estado de São Paulo. Somando seus Centros universitários e suas Universidades, a Anhanguera oferece 14 cursos de Pedagogia, sendo a instituição líder em número de cursos disponibilizados na cidade em questão, todos eles oferecidos na modalidade presencial.

Esta pesquisa investiga o perfil dos formandos no curso de Pedagogia de quatro instituições distintas, duas públicas e duas particulares. Dentre as instituições particulares, participam da pesquisa a Pontifícia Universidade Católica de São Paulo (PUC-SP) e a Universidade Bandeirante Anhanguera (UNIBAN-Anhanguera), campus Morumbi. No âmbito das instituições públicas foram investigados os alunos da Faculdade de Educação da Universidade de São Paulo (FEUSP) e os alunos da Universidade Federal de São Paulo (UNIFESP). A escolha destas universidades deu-se tendo em vista a inclusão de instituições díspares, cujas características peculiares atraem alunos com perfis também diversos. Assim, elementos como tempo de funcionamento, tipo de seleção dos ingressantes, localização e valor da mensalidade foram levados em consideração. 
A seleção das universidades particulares envolvidas nesta pesquisa foi guiada inicialmente pelo critério da popularidade e abrangência em termos do número de alunos atendidos. De acordo com o levantamento realizado em busca das instituições com maior poder de atuação no meio universitário privado, considerando-se o curso de Pedagogia, constatou-se a expressividade da organização Anhanguera Educacional, tanto na cidade, quanto no estado de São Paulo. Estes fatores justificam a escolha de uma de suas unidades para participar desta investigação, mais especificamente o campus Morumbi. Por outro lado, a fim de garantir a heterogeneidade das instituições participantes, entendeu-se que a Pontifícia Universidade Católica de São Paulo (PUC-SP) favoreceria um excelente contraponto, visto que uma de suas características principais abrange o elevado valor de sua mensalidade, elemento que restringe e particulariza significativamente o público atendido, ao mesmo tempo em que seu vestibular organiza-se de modo diferenciado em relação ao processo seletivo empregado pela Anhanguera Educacional. No caso das instituições públicas os critérios abrangeram o esforço em abarcar uma instituição estadual e outra federal, com históricos diversos - enquanto a Faculdade de Educação da USP entrou em funcionamento no ano de 1970, o curso de Pedagogia da UNIFESP, resultado de uma política recente de expansão do ensino superior público, foi inaugurado no ano de 2007. Além disso, as duas instituições utilizam processos seletivos ${ }^{5}$ diversos e localizam-se em regiões distintas do estado.

A diversificação das instituições é aqui entendida como uma estratégia metodológica para que se possa conhecer as formas de pensamento dos alunos, a partir de diferentes pontos de vista, considerando-se a multiplicidade de posições ocupadas por estes agentes no espaço social (Bourdieu, 2008). Tal perspectiva justifica o interesse em incluir neste estudo alunos com perfis possivelmente distintos em termos da posse de capital econômico, cultural e social, cuja heterogeneidade permitirá a elaboração de uma pesquisa mais abrangente acerca do tema em estudo.

\footnotetext{
${ }^{5}$ A apresentação dos processos seletivos empregados pelas instituições encontra-se no capítulo 2 desta tese.
} 


\subsection{A EXPANSÃO DO ENSINO SUPERIOR BRASILEIRO E AS ESPECIFICIDADES DAS INSTITUIÇÕES INVESTIGADAS}

Considerando-se a criação das universidades e demais instituições de ensino superior existentes em nosso país em termos de distribuição de organizações públicas e privadas, Barreyro (2008) destaca que já nos anos trinta era possível observar a preponderância do setor privado no que se refere ao oferecimento de educação superior no Brasil. Em 1933, o ensino privado representava $64,4 \%$ dos estabelecimentos de educação superior existentes, com destaque para as instituições de pequeno porte. De acordo com a autora, até 1960, o crescimento do ensino superior ocorreu com base na criação de institutos isolados e de universidades que aglutinavam alguns desses institutos.

Em 1961, a Lei de Diretrizes e Bases da Educação Nacional, dentre outras diretrizes, garantiu a plena equivalência de todos os cursos de grau médio, superando o caráter dualista que esse nível de ensino assumiu durante o Estado Novo. Essa equivalência foi considerada como fundamental na promoção da continuidade do crescimento do ensino superior no Brasil, diante de um significativo aumento da procura pelos cursos superiores, tal como destacou Cunha (2000). Considerando o aumento da demanda, o governo federal criou novas faculdades, estabeleceu a gratuidade dos cursos superiores das instituições federais e federalizou faculdades estaduais e privadas, ampliando a oferta pública de cursos superiores gratuitos. Entretanto, mesmo diante da ação do governo federal, Sampaio (2011, p.29) destaca que entre 1960 e 1980 o setor privado cresceu mais rapidamente que o público: "Entre 1960 e 1980, o número de matrículas no ensino superior passou de 200 mil para 1,4 milhão, em um crescimento de quase $500 \%$; no setor privado, o crescimento foi de mais de $800 \%$ ".

Em relação à condição dos cursos superiores na década de 1990, importa destacar a Lei de Diretrizes e Bases da Educação Nacional de 1996 (LDB/96), que regulamenta a Constituição de 1988 e permitiu a diversificação das instituições de ensino superior, possibilitando a criação de diferentes modalidades de organizações acadêmicas, tais como: centros universitários, faculdades integradas, faculdades e institutos ou escolas superiores, as quais podem oferecer seus cursos de formação, sem a obrigatoriedade de desenvolverem as atividades de pesquisa e extensão, obrigações estas restritas às universidades.

Além disso, a lei tornou possível o ingresso no ensino superior não só por meio dos exames vestibulares, mas também pela classificação mediante a realização de processos seletivos, os quais não foram especificados. Assim, modalidades de classificação do aluno a 
partir das notas obtidas ao longo de sua formação escolar ou por meio de provas aplicadas pelo Ministério da Educação (MEC), tornaram-se possíveis.

Como resposta o MEC instituiu o Exame Nacional do Ensino Médio (ENEM), em 1998. O objetivo desse exame é avaliar o desempenho do estudante no final de sua formação básica, entretanto, indivíduos que já concluíram o ensino médio anteriormente, também poderiam realizar esta prova. Desde a sua idealização, o ENEM foi pensado como modalidade avaliativa capaz de substituir totalmente o exame vestibular ou assumir um caráter de avaliação complementar aos exames de acesso ao ensino superior. Cunha (2003) destaca que as instituições privadas incorporaram rapidamente o resultado do ENEM como recurso para seleção de seus candidatos, entretanto, o mesmo não ocorreu com as instituições públicas, as quais só incorporaram o resultado desse exame diante de pressões exercidas pelo MEC.

Uma das maneiras criadas pelo Ministério da Educação em ocupar as vagas nas instituições federais de ensino superior, a partir da nota obtida no ENEM, se dá por meio da participação do aluno no Sistema de Seleção Unificada (SISU). Esse sistema foi desenvolvido em 2009 pelo Ministério da Educação, sendo a seleção realizada considerando-se a nota obtida pelo candidato no ENEM em relação às vagas disponíveis nas Instituições Federais. Algumas instituições também estabeleceram a adoção de notas mínimas, caso o candidato não tenha tirado no ENEM uma nota superior à mínima estabelecida, ele não poderá concorrer. Além disso, vale ressaltar que a nota de corte para cada carreira, depende também da nota dos candidatos interessados pela mesma. Assim, quanto mais alta for a nota dos candidatos a uma determinada carreira, maior será a nota de corte.

Na sua $1^{\mathrm{a}}$ edição, em 1998, o ENEM contou com um número de 157,2 mil inscritos e de 115,6 mil participantes. Entretanto, em 2004, as inscrições saltaram para o número de 3 milhões de inscrições e 2,2 milhões de participantes ${ }^{6}$. Tal ampliação deveu-se a instituição em 2005, no âmbito das ações do Ministério da Educação, do Programa Universidade para Todos (PROUNI), o qual terminou por vincular a nota obtida no exame à obtenção de bolsas em instituições privadas de ensino superior.

A fim de contextualizar o PROUNI, importa retomar a meta estabelecida pelo Plano Nacional de Educação (PNE - Lei n. 10.172/2001) que instituiu a expectativa de ampliar para $30 \%$ a proporção de jovens entre 18 a 24 anos, matriculados em curso superior até o ano de 2010. Tal meta foi estabelecida diante da constatação de que apenas $12 \%$ da população entre

\footnotetext{
${ }^{6}$ Os dados apresentados neste parágrafo foram obtidos no site do INEP: http://historico.enem.inep.gov.br
} 
18 a 24 anos frequentava esse nível de ensino. De acordo com o PNE, a ampliação das vagas no ensino superior poderia ocorrer por meio da utilização das vagas ociosas no setor privado, ao mesmo tempo em que as universidades públicas também expandissem suas vagas tendo em vista o atendimento da demanda. No âmbito destas últimas, foi sugerido que a expansão das vagas não fosse inferior a $40 \%$ do total existente. Além disso, o plano ressaltou a importância da expansão das vagas noturnas nas universidades federais.

Diante dessas expectativas, o Governo Federal institucionalizou em 2005 o PROUNI, cuja finalidade era conceder bolsas de estudo integrais e parciais em cursos de graduação e também nos cursos sequenciais de formação específica, em instituições de ensino superior privadas. Em benefício das instituições que aderissem ao programa, as mesmas seriam isentas de tributos cobrados por parte do governo.

Quanto às modalidades de bolsas oferecidas pelo programa, estabeleceu-se que as bolsas integrais seriam cedidas apenas às famílias com renda de até três salários mínimos. Para estes bolsistas, cuja carga horária do curso seja igual ou superior a seis horas diárias de aula, em cursos presenciais, com no mínimo seis semestres de duração, também foi oferecida uma Bolsa Permanência destinada ao custeio das despesas educacionais. Por outro lado, para os estudantes que obtiveram a bolsa parcial, foi criado o Fundo de Financiamento ao Estudante do Ensino Superior (FIES), que permite o financiamento de até $100 \%$ do valor da mensalidade não coberta pelo programa. ${ }^{7}$

O processo de ampliação do acesso ao ensino superior nos últimos anos também foi favorecido por políticas de expansão criadas pelo governo federal, tais como o Programa Expandir (2006); o sistema Universidade Aberta do Brasil - UAB (2005) e o Programa de Reestruturação e Expansão das Universidades Federais - REUNI (2008). Este último, teve por objetivo ampliar o acesso e a permanência no ensino superior federal, almejando dobrar o número de alunos nos curso de graduação em um prazo de dez anos e ainda permitir o ingresso de outros 680 mil alunos. Para que tal meta fosse atingida, as universidades federais comprometeram-se a aumentar as vagas oferecidas, especialmente nos cursos noturnos; reduzir a taxa de evasão e o custo por aluno; além de flexibilizar currículos e promover a ocupação das vagas ociosas ${ }^{8}$.

\footnotetext{
7 Os dados apresentados neste trabalho sobre o PROUNI foram obtidos no portal do MEC: http://ProUniportal.mec.gov.br

${ }^{8}$ As informações contidas neste parágrafo foram extraídas do portal do MEC: http://portal.mec.gov.br
} 
De acordo com o Censo da Educação Superior de 2010, houve uma tendência de ampliação do acesso a esse nível de ensino, já que o número de matrículas nos cursos de graduação aumentou 110,1\% entre os anos de 2001 a 2010. O documento alega que vários fatores devem ser considerados como justificativa para esse processo de expansão, tal como o aumento da demanda frente ao desenvolvimento econômico, além das políticas públicas de incentivo ao acesso e à permanência na educação superior, tais como os programas FIES e PROUNI, o aumento da oferta de vagas na rede federal, bem como o processo de interiorização.

Como resultado da política de expansão do ensino superior, iniciada no ano de 2003, "foram criadas 14 novas universidades e mais 100 novos campi que possibilitaram a ampliação de vagas e a criação de novos cursos de graduação.", no âmbito das universidades públicas. ${ }^{9}$ Diante dessa oferta o Censo de 2010 indica que as instituições federais, há dois anos consecutivos, apresentaram o maior crescimento percentual em termos de número de matrículas. Por outro lado, os dados apontam a estabilização do número de matrículas no setor privado, que mesmo assim, é o maior responsável pela formação superior da população brasileira, representando $74,2 \%$ das matrículas.

Ao traçar um panorama histórico da educação superior no Brasil, Durham (2003) aponta como característica fundamental de seu desenvolvimento, a evolução simultânea e precoce do sistema privado, ao lado do ensino público. Nesse primeiro momento, os dois sistemas partilhavam os mesmos ideais de compromisso social e objetivos formativos, porém, já na década de 1960 parte do setor privado começou a romper com o modelo da universidade de pesquisa, assumindo um modo de organização empresarial, cujo objetivo primeiro era a obtenção de ganhos financeiros.

Martins (2009, p. 16) destaca que esse novo perfil de ensino superior privado deu-se como uma consequência da Reforma Universitária de 1968, “uma vez que as modificações introduzidas nas universidades federais não conseguiram ampliar satisfatoriamente suas matrículas para atender à crescente demanda de acesso." Em 1969, o Grupo de Trabalho da Reforma Universitária, instituído pelo governo para o planejamento de soluções e medidas voltadas para a eficácia do sistema universitário, tornou possível a participação do setor privado, por meio de estabelecimentos isolados, no atendimento da demanda pelo ensino superior. Inicialmente esse atendimento ocorreria em situações excepcionais, entretanto, deuse com essa medida o favorecimento do processo de expansão do setor privado que se

\footnotetext{
${ }^{9}$ Dados obtidos no portal do MEC: http://reuni.mec.gov.br
} 
consolidou logo a seguir. De acordo com Durham (2003), até o ano de 1965 a participação do setor privado no total do atendimento da demanda por ensino superior era de aproximadamente 45\%, já a partir de 1970 sua presença superava o índice de $60 \%$.

O atendimento oferecido pelo setor privado após a Reforma de 1968, porém, deu-se por meio de "instituições organizadas a partir de estabelecimentos isolados, voltados à mera transmissão de conhecimentos de cunho marcadamente profissionalizante e distanciados da atividade de pesquisa" (MARTINS, 2009, p. 17). Tendo em vista o alcance de um número significativo de alunos, as instituições ofereciam cursos de baixo custo para um alunado pouco selecionado, enquanto a pesquisa não fazia parte desse meio pelo fato de envolver custos e não gerar lucros aos seus proprietários. Salem (1982) ressalta, contudo, que o ensino privado católico não aceitou seguir o modelo empresarial, prioritariamente voltado para fins lucrativos. Nesse contexto, o sistema privado foi dividido em dois segmentos: o setor empresarial e o setor comunitário, que se orienta pelos princípios organizacionais do sistema público de ensino superior.

Dentre as universidades particulares investigadas nesta pesquisa foram selecionadas duas instituições que contemplam a divisão interna do sistema privado, tal como foi exposto. A Universidade Bandeirante Anhanguera (UNIBAN-Anhanguera) retrata as instituições privadas empresariais, enquanto o setor comunitário confessional é representado pela Pontifícia Universidade Católica de São Paulo (PUC-SP).

De acordo com Schmidt (2010) e Bittar (2001), as instituições comunitárias dirigem suas ações para o atendimento da coletividade em suas necessidades, por meio da prestação de serviços na área social, sendo esta uma característica essencial dos estabelecimentos que assumem essa denominação. Entende-se que essas instituições, sem pertencerem ao âmbito estatal, compartilham com o mesmo a tarefa de proporcionar serviços de interesse público. As universidades comunitárias, nesse sentido, são orientadas por uma vocação pública tendo em vista o desenvolvimento comunitário que se concretiza por meio das atividades de ensino, pesquisa e extensão, além de não possuírem fins lucrativos. Destaca-se, ainda, que essas instituições priorizam o ensino qualificado, uma vez que os recursos financeiros obtidos com as mensalidades são direcionados para a manutenção de suas próprias atividades, tais como o "desenvolvimento de laboratórios, de pesquisas, novos cursos, tanto de graduação quanto de pós-graduação, voltados para a comunidade e para a extensão das atividades nos cursos" (SANDANO e VENANZI, 2014, p. 153). 
Em estudo a respeito do ensino superior privado no Brasil, vinculado ao Banco Nacional de Desenvolvimento Econômico e Social, Sécca e Leal (2011, p.124 e 125) caracterizam as Pontifícias Universidades Católicas como instituições tradicionais que oferecem cursos de "reconhecida qualidade". Além disso, o perfil de seu alunado é identificado como pertencente às classes sociais mais privilegiadas, uma vez que a mensalidade de seus cursos possuem um valor significativamente elevado. Ao mesmo tempo, são estudantes cuja faixa etária corresponde a um percurso formativo sem interrupções, enquanto o ensino médio foi cursado prioritariamente em instituições particulares de ensino. Por fim, são alunos que tiveram a oportunidade de dedicar-se totalmente aos estudos, desenvolvendo atividades que comprometem sua dedicação integral ao curso somente quando dão início aos estágios.

Enquanto entre as décadas de 1960 e 1970 a expansão do setor privado laico ocorreu sobretudo por meio de estabelecimentos isolados, a partir da década de 1980 houve um movimento de transformação dos mesmos em universidades, favorecido pelo Conselho Federal de Educação que autorizou tais conversões. De acordo com Martins (2009, p. 23), entre os anos de 1985 e 1996 o número de universidades privadas "mais do que triplicou", entretanto, essas instituições priorizavam as atividades de profissionalização, em detrimento da tríade ensino, pesquisa e extensão. $\mathrm{O}$ autor ressalta, ainda, que a posição política assumida durante o mandato do Presidente Fernando Henrique Cardoso (1995-2003) retraiu os gastos com o ensino superior público, favorecendo mais uma vez o crescimento do setor privado. Nesse mesmo período, o Decreto n. 2207/1997 diferenciou as instituições comunitárias dos estabelecimentos privados com fins lucrativos, dando-se a regulação do que o autor denominou como capitalismo acadêmico.

Nas palavras de Oliveira (2009, p. 740), o capitalismo acadêmico consiste na "transformação da educação em objeto de interesse do grande capital, ocasionando uma crescente comercialização do setor." Essa comercialização foi ampliada ainda mais pelo processo de participação do capital financeiro na educação, seguida pela internacionalização de sua oferta, tal como ocorreu no processo de aquisição da Anhanguera Educacional por um fundo de investimentos gerido pelo Banco Pátria, cujas ações foram lançadas na Bolsa de Valores de São Paulo em 2007, sendo as mesmas adquiridas em grande parte por estrangeiros.

Após a abertura do capital da Anhanguera Educacional no mercado de ações deu-se um processo acentuado de aquisições, por parte da mesma, de novos estabelecimentos de ensino, estando entre eles a Universidade Bandeirante de São Paulo, adquirida no ano de 2011. Oliveira (2009) ressalta o crescimento considerável das instituições privadas com fins 
lucrativos que contaram com sua inserção em negociações na bolsa de valores. No caso da Anhanguera Educacional, até o final de 2012 a instituição já contava com 70 campi e mais de 500 polos de educação a distância, momento no qual a instituição se denominava como "uma das maiores instituições de ensino do mundo em número de alunos"10.

No site da instituição UNIBAN-Anhanguera é possível identificar que a mesma possui como público-alvo adultos das classes média e baixa, os quais trabalham durante o dia e estudam no período noturno. Trata-se, portanto, de uma instituição de massa que oferece cursos em instalações multicampi, por meio da cobrança de mensalidades de baixo custo. Tais mensalidades são possíveis graças a um processo de racionalização administrativa que termina por afetar diretamente a organização do trabalho acadêmico, assim como indicado por Oliveira (2009, p. 744):

(...) juntam-se classes para atividades de estudo. Como o pagamento dos professores é por hora-aula, dependendo do número de classes que são agrupadas, a economia pode ser intensa. (...) Além (...) de estudos conjuntos na biblioteca, pode-se utilizar de atividades de instrução programada nos laboratórios de informática, contabilizadas como aula na grade curricular, e o engenhoso mecanismo da 'aula fictícia'. Os professores contratados por horaaula ganham adicional noturno após as 22 horas. Assim, encerram-se as atividades com os professores nesse horário, ainda que na grade curricular conste mais uma aula. Nesse caso, ou os alunos realizam estas atividades de laboratório de informática e biblioteca, ou simplesmente são dispensados.

Numa perspectiva oposta à da PUC-SP, a Universidade Bandeirante Anhanguera pertence ao segmento do ensino superior privado voltado ao atendimento das demandas do mercado, inserida num processo de mercantilização da educação superior em que a qualidade acadêmica é secundarizada ante a perspectiva da obtenção do lucro. Longe de possuir como objetivo a formação da elite intelectual do país, trata-se de um estabelecimento de ensino voltado às classes populares que deseja qualificar seus alunos para o mercado de trabalho, atendendo suas expectativas de ascensão social e profissional (SÉCCA e LEAL, 2011).

Apesar do setor privado responder atualmente pelo maior número de vagas disponíveis no âmbito do ensino superior, deve ser levado em consideração o recente processo de expansão do ensino universitário público, principalmente no contexto das instituições federais. Tal ampliação resultou de políticas governamentais com destaque para o Programa Expandir e o Programa de Apoio a Planos de Reestruturação e Expansão das Universidades Federais

${ }^{10}$ Citação retirada no site da instituição denominado "Relação com investidores - Visão Geral”. Disponível em:<http://www.mzweb.com.br/anhanguera2011/web/conteudo_pt.asp?idioma=0\&conta=28\&tipo=39356>.

Acesso em: 28 out. 2013. 
(REUNI). O primeiro programa foi instituído em 2006 e previu, por meio de dotação orçamentária, a criação de novas universidades e campi universitários em regiões diversificadas do país. O REUNI, por sua vez, consistiu na proposta do Ministério da Educação em destinar recursos financeiros às universidades federais que aderissem às diretrizes do programa e apresentassem seus planos de reestruturação. Tais planos deveriam abranger propostas objetivando a expansão das vagas (novos campi, novos cursos, ampliação das vagas no período noturno); a expansão geográfica (interiorização e ocupação das periferias metropolitanas) e a expansão do acesso (novos mecanismos de ingresso e reserva de vagas), tendo em vista a inclusão no meio universitário de grupos sociais que tradicionalmente não frequentavam esse espaço formativo (CEPÊDA e MARQUES, 2012). Por fim, o programa determinou também a adoção nas universidades de mecanismos que reduzissem as taxas de evasão e oferecessem recursos de assistência estudantil, a fim de assegurar não somente o acesso, mas também a permanência dos ingressantes nas novas instituições.

Nesse contexto de medidas expansionistas, a Universidade Federal de São Paulo ampliou seu espaço de atuação, centrado anteriormente em cursos na área da saúde. Atualmente a universidade conta com seis campi e oferece formação nas áreas de ciências humanas, exatas e biológicas. O curso de Pedagogia é oferecido no campus de Guarulhos, o qual foi inaugurado em 2007 e é totalmente dedicado à formação na área de humanidades. Situado no Bairro dos Pimentas, região periférica de Guarulhos, a localidade do campus responde aos interesses de expansão geográfica do governo, tendo em vista a inserção de instituições de formação universitária em localidades "com grande densidade populacional e baixa cobertura universitária de nível público.” (CEPÊDA e MARQUES, 2012, p. 183).

Em relação ao seu processo seletivo, obedecendo novamente às recomendações do REUNI no que se refere à diversificação das estratégias adotadas, determinados cursos da UNIFESP (com inclusão do curso de Pedagogia) aderiram ao Sistema de Seleção Unificada (Sisu), cuja atribuição das vagas ocorre exclusivamente a partir dos resultados obtidos pelos candidatos no Exame Nacional do Ensino médio (Enem). Além disso, a UNIFESP passou a reservar parte de suas vagas a candidatos que cursaram o ensino médio integralmente em escolas públicas, havendo dentre estas uma divisão de cotas sociais e raciais.

Cumprindo com as expectativas dos programas governamentais em curso, o conjunto de mecanismos de democratização do acesso e favorecimento da permanência dos estudantes na universidade terminou por contribuir com o ingresso de um perfil de aluno diferente daquele comum aos cursos na área da saúde oferecidos pela instituição. De acordo com Lugli (2014), 
os alunos do campus da UNIFESP de Guarulhos pertencem aos grupos socioeconômicos menos privilegiados, dos quais partem o maior número de solicitações em termos de auxílios sociais (moradia, transporte, alimentação) perante os demais campi. Nesta unidade, os alunos são trabalhadores e possuem faixa etária mais elevada, indicando possivelmente o adiamento da perspectiva de cursar uma formação universitária. Os estudantes também são majoritariamente egressos de escolas públicas e seus pais possuem baixa formação escolar, fatores que conferem aos mesmos a posse de um fraco capital cultural.

Apesar da democratização do acesso ao ensino superior e da mudança no perfil do alunado, as práticas formativas na UNIFESP de Guarulhos não foram modificadas, pois o campus dedica-se à formação humanista, seguindo o modelo da Universidade de São Paulo, o qual, por sua vez, sofreu forte influência da concepção universitária europeia no momento de sua fundação. O projeto acadêmico inicial do campus de Guarulhos previa a frequência obrigatória dos alunos de todos os cursos à disciplina de filosofia, além de um semestre de inglês e francês instrumental para a leitura de textos no idioma original. O projeto também propunha a obrigatoriedade dos graduandos concluírem disciplinas em cursos diferentes da sua formação de ingresso. Essa proposta acadêmica foi guiada por uma concepção tradicional de universidade e teve por objetivo: "garantir o rigor do pensamento, uma sólida cultura geral e uma vivência ampla da riqueza cultural da universidade, ou seja, a explícita valorização dos elementos mais desvinculados da função instrumental do ensino superior, relativa à formação profissional." (LUGLI, 2014, p. 302). Entretanto, a distância entre o perfil dos estudantes do campus de Guarulhos e a concepção de universidade detalhada em seu projeto acadêmico e partilhada por seus professores, resultou em um certo desencontro entre as expectativas docentes em relação ao rendimento esperado de seus alunos e o que estes poderiam de fato realizar em termos acadêmicos, considerando-se sua origem social. Por parte dos alunos, Lugli (2014) relata a percepção de um sentimento de fracasso e inadequação ao meio universitário, situação que exige a busca por um novo formato de ensino superior, que mantenha a qualidade formativa e ao mesmo tempo atenda ao perfil desse novo alunado.

A influência do modelo da Universidade de São Paulo na elaboração do projeto acadêmico inicial do campus de Guarulhos da UNIFESP, tal como foi apontado por Lugli (2014), remete ao momento de criação da USP, na década de 1930. De acordo com a concepção de seus idealizadores o objetivo existente em torno da fundação da Universidade de São Paulo consistia na perspectiva dessa instituição se consolidar como um espaço de formação dos quadros dirigentes, munidos por conhecimentos elevados no âmbito da cultura, ciência, 
literatura e artes. Perseguia-se um ideal de cultura livre e desinteressada, isento de qualquer interesse formativo voltado simplesmente para a formação profissionalizante e técnica, o qual seria conquistado por meio da frequência dos alunos à Faculdade de Filosofia, Ciências e Letras (FFCL) (CATANI e HEY, 2006).

A Faculdade de Filosofia, Ciências e Letras (FFCL) foi idealizada como o núcleo da Universidade de São Paulo oferecendo para todos os estudantes da instituição, independentemente de sua graduação de origem, cursos de formação geral e estudos desinteressados. Em 1926, Fernando de Azevedo (um dos idealizadores da USP) já identificava a formação universitária especializada e dirigida à profissionalização como insuficiente e defendia o preparo da intelectualidade por meio do estudo de conteúdos gerais e não pragmáticos (PAULA, 2002).

A concepção de universidade como espaço destinado à formação das elites dirigentes tendo como centro a Faculdade de Filosofia, Ciências e Letras, se assemelha ao modelo universitário alemão, instituído a partir da fundação da Universidade de Berlim no início do século XIX. De acordo com Paula (2002), é possível identificar uma série de proximidades entre a proposta de criação da USP e a concepção universitária alemã, tais como:

(...) preocupação fundamental com a pesquisa e com a unidade entre ensino e investigação científica; ênfase na formação geral e humanista, ao invés da formação meramente profissional; autonomia relativa da universidade diante do Estado e dos poderes políticos; concepção idealista e não-pragmática de universidade, em detrimento da concepção de universidade como prestadora de serviços ao mercado e à sociedade; fraco vínculo entre intelectuais e poder político (...); concepção liberal e elitista de universidade; estreita ligação entre a formação das elites dirigentes e a questão da nacionalidade. (Paula, 2002, p. 151)

Assim, tal como emerge no modelo alemão, a USP estabeleceu entre as suas finalidades a ênfase na indissociabilidade entre ensino, pesquisa e formação, ao mesmo tempo que enfatizou a formação geral, de caráter científico e humanista, seguindo-se daí a importância da Faculdade de Filosofia, Ciências e Letras. Contudo, além da influência do modelo alemão, deve-se destacar a participação de professores vindos de universidades francesas os quais inspiraram significativamente o processo de consolidação dos estudos em ciências humanas da USP, por meio da implantação de temas de investigação desconhecidos no Brasil, assim como pela colaboração no processo formativo de especialistas e intelectuais de alto nível no interior da universidade (CATANI e HEY, 2006; PAULA, 2002). 
Catani e Hey (2006) destacam, porém, que a centralidade da Faculdade de Filosofia, Ciências e Letras, tal como se planejou no momento da criação da universidade, não foi realmente efetivada, sendo a unidade desmembrada posteriormente em diferentes institutos e faculdades. Além disso, apesar de ter sido imaginada como o espaço formativo das elites, estas não se dirigiam para os seus cursos, mantendo as mesmas o interesse pelas graduações tradicionais tais como direito, medicina e engenharia.

Inicialmente orientada por uma concepção liberal e elitista, contexto em que se defendia a igualdade de oportunidades e a seleção dos mais capazes, a Universidade de São Paulo se afastou do modelo adotado originalmente, sobretudo a partir dos anos de 1970, momento no qual se deu a ampliação da oferta de vagas e a abertura de novos cursos (CATANI e HEY, 2006, p. 240). De acordo com Carlotto (2014), a partir da década de 1970 a universidade se expandiu principalmente por meio da criação de novas unidades e cursos de caráter técnico ou profissionalizante, no interior do estado de São Paulo. Por outro lado, a autora identificou que as "unidades mais tradicionais", situadas na capital e responsáveis pelos cursos de Direito, Medicina e Engenharia, praticamente não ampliaram suas vagas, contribuindo para a manutenção do caráter elitizado e seletivo dos mesmos.

Para além da criação de novas unidades no interior do estado, no ano de 2005, deu-se a fundação da Escola de Artes, Ciências e Humanidades (EACH), situada na zona leste da cidade de São Paulo. A decisão pela implantação dessa nova unidade respondeu aos interesses da universidade em expandir suas vagas e cursos, tendo em vista a promoção do desenvolvimento social em áreas vulneráveis do município. Desse modo, a zona leste foi escolhida pelo fato de ser uma das regiões mais populosas da cidade e, ao mesmo tempo, insuficientemente estruturada em termos de condições de moradia, acesso a bens culturais e educacionais (CARLOTTO E GARCIA, 2013). A criação da EACH representa, portanto, a adoção de uma política inclusiva por parte da Universidade de São Paulo, tendo em vista a extensão de sua ação educacional a um público que costumeiramente não era por ela abrangido (CATANI e HEY, 2006).

As ações inclusivas da Universidade de São Paulo foram ampliadas no ano de 2006 por meio da adoção do Programa de Inclusão Social da USP (INCLUSP), o qual, através do sistema de pontuação acrescida, aumentou as chances de aprovação no vestibular dos alunos que cursaram o ensino básico em escolas públicas por meio da atribuição de bônus. Tais medidas foram ampliadas quando, em 2013, o Conselho Universitário da USP aprovou a instituição de um bônus de $5 \%$ na nota final do vestibular para candidatos que cursaram o ensino 
básico em escola pública e que se autodeclararam preto, pardo ou indígena. De acordo com a Pró-Reitoria de Graduação, espera-se que até 2018 cinquenta por cento de todas as matrículas, em todos cursos e turnos, sejam realizadas por alunos egressos da rede pública de ensino. Em termos raciais, o objetivo é que o número de alunos pretos, pardos e indígenas seja proporcional à porcentagem dessa população, de acordo com o último censo do Instituto Brasileiro de Geografia e Estatística (IBGE).

De qualquer modo, apesar de todas as medidas inclusivas adotadas recentemente pela instituição, ainda persiste a associação entre os cursos mais concorridos e o ingresso de alunos oriundos de famílias com melhores condições sociais e de renda, os quais concluíram sua educação básica em instituições privadas de ensino, uma vez que, tal como evidenciou Carlotto (2014, p. 357), a ampliação das vagas efetivadas pela Universidade não incluiu as carreiras tradicionais, mas sim novas profissões que terminaram por atrair grupos sociais menos privilegiados: “(...) os cursos menos concorridos da USP, além de serem ligados a novas formações profissionais, são, também, e por isso mesmo, relativamente mais abertos a novos setores sociais do que a média geral dos cursos da USP."

A caracterização das quatro universidades que tiveram seus cursos de Pedagogia investigados revela que as mesmas possuem origens distintas, não só em termos temporais havendo instituições mais jovens como a UNIFESP e a UNIBAN-Anhanguera, além de outras mais longevas e tradicionais como a PUC-SP e USP, mas também no que se refere aos objetivos institucionais e formativos. Enquanto a UNIBAN-Anhanguera possui uma clara orientação mercadológica, visando ao lucro e à formação profissional das classes populares, a PUC-SP, como instituição comunitária e sem fins lucrativos, tem interesse em contribuir com a formação qualificada de seus estudantes e, ao mesmo tempo, cooperar com o desenvolvimento social por meio de suas atividades de ensino, pesquisa e extensão. Trata-se, ainda, de uma instituição que requer o pagamento de mensalidades elevadas e, por consequência, termina por deter entre o seu alunado aqueles que pertencem a grupos sociais mais seletos. A UNIFESP de Guarulhos, por sua vez, desponta como um campi fruto de um projeto federal de expansão e democratização do acesso ao ensino superior, voltado justamente para o atendimento de grupos sociais que comumente não eram abrangidos pela formação universitária, ao mesmo tempo que nutre um planejamento acadêmico orientado por princípios de uma educação de excelência, intelectualizada, não pragmática e marcada pela associação entre ensino e pesquisa. Por fim, a Universidade de São Paulo, uma das instituições públicas mais tradicionais no contexto do ensino superior brasileiro, cujo desempenho também é reconhecido em rankings 
internacionais ${ }^{11}$ e se destaca pela qualidade dos trabalhos desenvolvidos no âmbito do ensino, pesquisa, cultura e extensão. Criada a partir de um projeto político que visava à formação de uma elite intelectual e a seleção dos mais capazes, atualmente assumiu uma perspectiva mais democrática em relação aos alunos que usufruirão de suas atividades formativas sem, contudo, abandonar a dimensão do mérito acadêmico a ser demonstrado por seus candidatos no momento da realização do exame vestibular.

Tendo em vista o conhecimento mais aprofundado da proposta formativa das universidades em estudo, foi realizado um trabalho de leitura dos projetos políticos pedagógicos, além do levantamento do sistema de ingresso implementado em cada instituição. Com a posse dessas informações, foi possível organizar um quadro (Quadro 1.1) que sintetiza as principais características das universidades em estudo, com destaque para a categoria administrativa da instituição; habilitações oferecidas; duração mínima do curso; estágio obrigatório; atividades formativas; existência de disciplina a distância, exigência de trabalho de conclusão de curso, sistema de ingresso, turnos e vagas disponíveis, apresentado a seguir ${ }^{12}$ :

\section{Quadro 1.1 - Características gerais das universidades em estudo}

\begin{tabular}{|c|c|c|c|c|}
\hline & FEUSP & UNIFESP & PUC-SP & UNIBAN-Anhanguera Educacional \\
\hline Fundação & 1970 & 2007 & 1946 & 2005 \\
\hline Categoria administrativa & Pública Estadual & Pública Federal & Privada sem fins lucrativos & Privada com fins lucrativos \\
\hline Habilitações oferecidas & \begin{tabular}{|c|} 
Magistério das matérias \\
pedagógicas do ensino médio; \\
Magistério da Educação Infantil; \\
Magistério das séries iniciais do \\
ensino fundamental e Habilitação \\
integrada: Administração Escolar \\
da Educação Básica; Supervisão \\
Escolar da Educação Básica e \\
Orientação Educacional da \\
Educação Básica.
\end{tabular} & \begin{tabular}{|} 
Docência na Educação Infantil e \\
anos iniciais do Ensino \\
Fundamental; Coordenação \\
Pedagógica; Orientação \\
educacional; Direção escolar e \\
Supervisão e Gestão do sistema de \\
ensino no plano local e regional.
\end{tabular} & \begin{tabular}{|} 
Docência na Educação Infantil e \\
anos iniciais do Ensino \\
Fundamental; Coordenação \\
Pedagógica; Direção escolar; \\
Coordenação de serviços de apoio \\
escolar em escolas e em \\
instituições educacionais não \\
escolares e Gestão de processos \\
educativos na educação escolar e \\
não escolar.
\end{tabular} & \begin{tabular}{|} 
Docência na Educação Infantil, nos \\
anos iniciais do Ensino \\
Fundamental e no Ensino Médio \\
na modalidade normal de \\
Educação Profissional; Gestão, \\
Orientação e Coordenação \\
educacional e Supervisão Escolar.
\end{tabular} \\
\hline Duração mínima do curso & 4 anos e meio ( 3.270 horas) & 4 anos ( 3.555 horas) & 4 anos ( 3.200 horas) & 3 anos ( 3.410 horas) \\
\hline Estágio obrigatório & 450 horas & 300 horas & 300 horas* & 350 \\
\hline Atividades Práticas & 570 horas & incorporadas nas disciplinas & - & - \\
\hline Estudos independentes & 480 horas & - & - & - \\
\hline Atividades complementares & - & 105 horas & 100 horas* & 100 horas \\
\hline Disciplinas a distância & 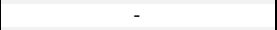 & - & 100 horas & 320 horas \\
\hline Trabalho de Conclusão do Curso (TCC) & facultativo (180 horas) & obrigatório (75 horas) & obrigatório ( 80 horas) & - \\
\hline Sistema de ingresso & $\begin{array}{c}\text { Vestibular FUVEST (Com } \\
\text { aproveitamento da nota do ENEM) }\end{array}$ & SISU-ENEM & $\begin{array}{l}\text { Vestibular. Aproveitamento do } \\
\text { ENEM somente para estudantes } \\
\text { bolsistas do PROUNI. }\end{array}$ & Vestibular ou ENEM \\
\hline Período & vespertino e noturno & vespertino e noturno & matutino e noturno & noturno \\
\hline Vagas & $180(60 V+120 N)$ & $120(60 \mathrm{~V}+60 \mathrm{~N})$ & $\begin{array}{c}80 \text { vagas por turno }+40 \text { vagas } \\
\text { complementares (vestibular de } \\
\text { inverno) }\end{array}$ & 90 por turno \\
\hline
\end{tabular}

Observações: *Contabilizadas fora da matriz horária

\footnotetext{
${ }^{11}$ Considerando seus resultados mais recentes, a USP está entre as dez primeiras classificadas na terceira edição do ranking elaborado pelo Quacquarelli Symonds (instituto britânico especializado em educação superior) a respeito das 200 melhores universidades dos países do Brics. A Universidade assumiu ainda o primeiro lugar entre as melhores instituições da América Latina no ranking Webometrics e ocupa a $132^{\circ}$ posição no $Q S$ World University, que avalia mais de três mil universidades do mundo. Disponível em: $<$ http://www5.usp.br/94800/uspe-a-nona-melhor-universidade-entre-os-paises-do-brics/>. Acesso em: 10 jul. 2015.

${ }^{12}$ No Apêndice desta tese é apresentado de modo pormenorizado o histórico de origem das universidades, o estudo acerca do Projeto Político Pedagógico das mesmas, bem como o detalhamento dos processos seletivos adotados por cada uma delas.
} 
De modo geral as instituições investigadas possuem características que as diferenciam significativamente, ao mesmo tempo em que há algumas peculiaridades que as aproximam. Em termos de proposta pedagógica observou-se que as instituições procuraram renovar a estrutura geral de seus cursos, oferecendo aos alunos uma formação com caráter interdisciplinar (PUCSP), esforçando-se pela aproximação entre formação teórica e prática pedagógica (USP, UNIFESP, PUC-SP). O estágio, nos casos da UNIFESP e PUC-SP, é acompanhado de forma mais sistemática, havendo professores designados especialmente para discutir com os alunos suas experiências.

A indissociabilidade entre ensino e pesquisa é alegada pelas quatro instituições, entretanto, na UNIBAN-Anhanguera, a iniciação científica não é usual e seus raros projetos são continuamente interrompidos. Nesta instituição os alunos são dispensados da realização do TCC e a prática de estágio não é supervisionada, nem discutida por algum profissional indicado pela universidade. No caso da FEUSP destacam-se a prática da iniciação científica e a elaboração do trabalho de conclusão do curso (TCC), mesmo que não obrigatório. Na UNIFESP a iniciação do aluno à pesquisa ocorre por meio das Práticas Pedagógicas Programadas, que envolvem pesquisa de campo e intervenção comunitária, sob a supervisão do professor preceptor; a prática do estágio supervisionado, ou como denominam, residência pedagógica; a participação em projetos de iniciação científica, além da elaboração do TCC ao término do curso. Tal como na UNIFESP, o trabalho de conclusão do curso na PUC-SP é obrigatório, e esta instituição entende que o preparo do aluno para a elaboração do TCC deve ocorrer ao longo de toda a graduação, por meio da prática do estágio e participação em pesquisas de iniciação científica.

A partir do estudo das propostas pedagógicas nota-se que há um certo alinhamento entre USP, UNIFESP e PUC-SP, seja em termos de flexibilidade curricular, articulação teoria e prática e indissociabilidade entre ensino e pesquisa. Nestes quesitos, a instituição que mais se diferencia é a UNIBAN-Anhanguera. Por outro lado, o processo seletivo empregado, a disponibilidade de vagas, a localização da universidade, o valor da mensalidade e o perfil do corpo docente terminam por atuarem como elementos de distinção das instituições investigadas, capazes de atrair para si alunos com perfis diferenciados.

Assim, a seleção proposital de universidades dotadas de características distintas, acompanhada do esforço em retratar o alunado do curso de Pedagogia das mesmas, permitiu a identificação de variações em relação à origem social dos estudantes, bem como em suas práticas culturais, as quais se diversificaram de acordo com a instituição de origem dos 
estudantes. Do mesmo modo, foi possível observar proximidades e distanciamentos nas justificativas acerca da escolha profissional, representações sobre a profissão docente e perspectivas profissionais e formativas, sendo este o conteúdo a ser abordado nos capítulos seguintes desta tese. 


\section{2 “Eu Quero ser professora!” A adesão ho curso de Pedagogia e AO TRABALHO DOCENTE - O CASO UNIBAN-ANHANGUERA}

\subsection{AS CLASSES POPULARES EM UMA INSTITUIÇÃO POPULAR}

Nesta universidade contamos com a participação de vinte respondentes, sendo todo o grupo composto exclusivamente por mulheres, cuja faixa etária supera os trinta anos e, em termos raciais, dividem-se equilibradamente entre as que se autodenominam como brancas e negras ${ }^{1}$. Quanto ao estado civil, nota-se um ligeiro predomínio das solteiras, enquanto metade do grupo já possui filhos, conforme evidencia a Tabela 2.1 .

Tabela 2.1 - Distribuição dos respondentes da Uniban/Anhanguera segundo as variáveis sexo, idade, raça e estado civil.

\begin{tabular}{lll}
\hline Variáveis & Categorias & $\mathbf{n}$ \\
\hline Sexo & Feminino & 20 \\
Total & & 20 \\
Faixa etária & 20 a 25 & 4 \\
& 26 a 30 & 5 \\
Total & 31 ou mais & 11 \\
& & 20 \\
Raça & Branco & 9 \\
& Pardo & 8 \\
& Preto & 1 \\
& Indígena & 1 \\
Total & Amarelo & 1 \\
& & 20 \\
Estado conjugal & Casada & 8 \\
& Solteira & 11 \\
Total & Divorciada & 1 \\
& & 20 \\
Filhos & Sim & 10 \\
Total & Não & 10 \\
\hline
\end{tabular}

Egressas da rede pública de ensino, estas respondentes cursaram o ensino fundamental e médio essencialmente nas escolas públicas paulistas ${ }^{2}$, havendo poucas alunas que concluíram o ensino médio em outros estados. Nestes casos, tratam-se de estudantes que frequentaram

\footnotetext{
${ }^{1}$ De acordo com o IBGE a categoria negro inclui a somatória da população preta e parda.

${ }^{2}$ Somente duas alunas frequentaram em algum momento da sua formação escolar básica instituições de caráter privado, ainda assim, por períodos bastante breves.
} 
instituições localizadas prioritariamente no nordeste brasileiro, em estados como Bahia, Pernambuco e Rio Grande do Norte (Tabela 3.2).

A modalidade de ensino médio predominante cursada foi o regular, ao mesmo tempo que se observa uma pequena presença de alunas que frequentaram a educação de jovens e adultos e o curso normal/magistério. Deve ser destacado o fato do ensino médio ter sido cursado no período noturno por grande parte deste grupo, momento em que a experiência do trabalho, ainda nesta etapa de formação escolar, fez parte da realidade de mais da metade do grupo investigado, havendo um leve predomínio das atividades desenvolvidas em jornadas integrais (Tabela 2.2).

No período entre a finalização do ensino médio e ingresso no ensino superior, poucas estudantes frequentaram cursinhos preparatórios para o vestibular e o intervalo entre a conclusão do ensino médio e ingresso no curso de graduação em Pedagogia, para 11 das 20 alunas participantes, foi marcado por uma espera de cinco anos ou mais (Tabela 2.2). 
Tabela 2.2 - Distribuição dos respondentes da Uniban/Anhanguera segundo a trajetória escolar, trabalho e intervalo entre o encerramento do ensino médio e ingresso no ensino superior.

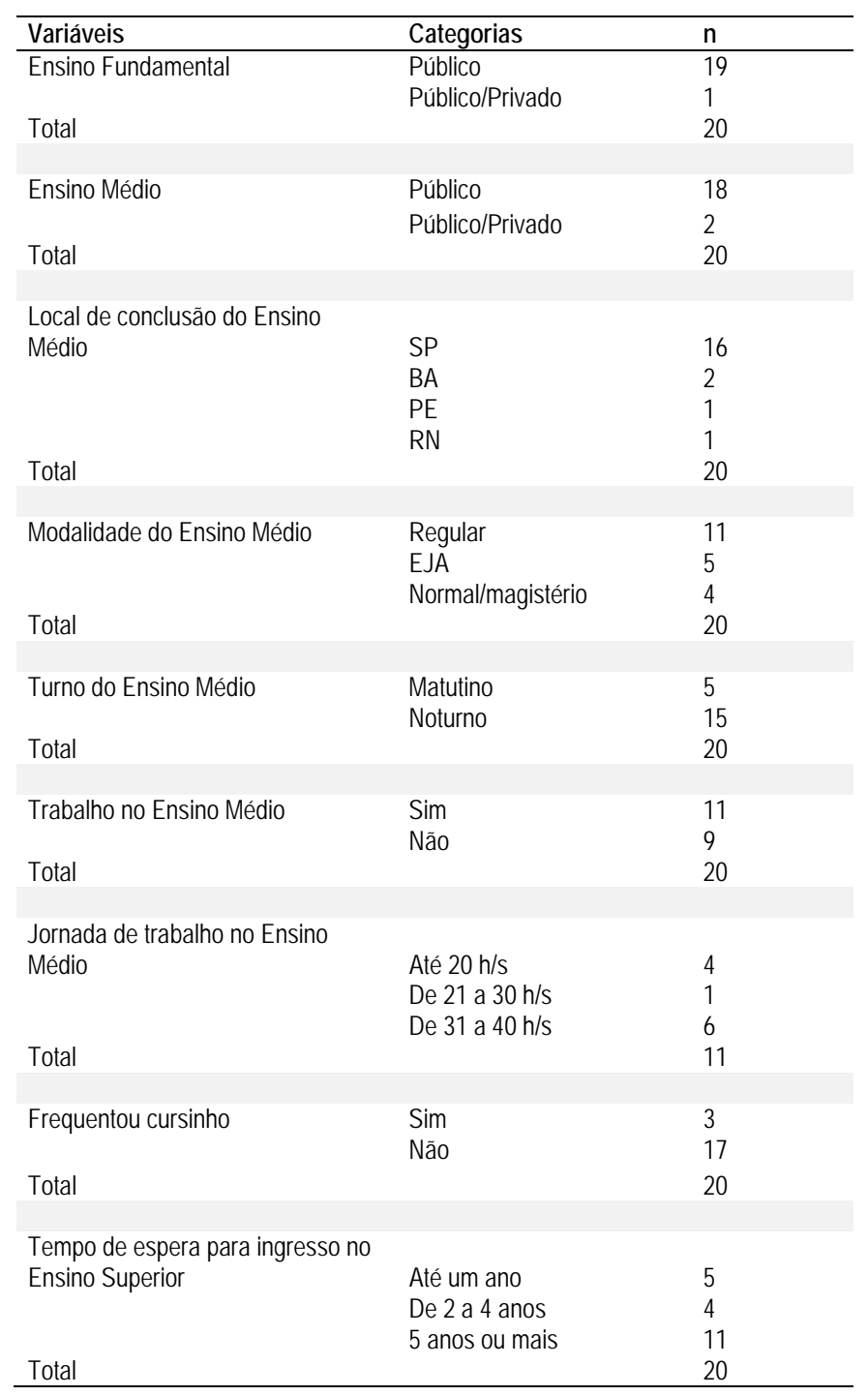

Considerando-se o nível de escolaridade paterno e materno das respondentes, apresentado na Tabela 2.3, destaca-se que grande parte possui até o ensino fundamental completo, sendo raros os casos em que algum dos pais concluiu o ensino médio ou superior. Acompanhando o nível de formação escolar, as atividades ocupacionais desenvolvidas pelos pais destas alunas concentram-se no desenvolvimento de trabalhos manuais, de baixa remuneração e pouco reconhecimento social. No caso dos homens, as atividades mais comumente mencionadas foram operário, pedreiro, mecânico e motorista, enquanto dentre as mulheres as ocupações mais frequentes vincularam-se às atividades domésticas e funções como as de cozinheira, auxiliar de limpeza, servente, entre outras com características similares. 
Tabela 2.3 - Distribuição dos respondentes da Uniban/Anhanguera segundo o nível de instrução paterno e materno e ocupação desenvolvida pelos mesmos.

\begin{tabular}{|c|c|c|}
\hline Variáveis & Categorias & $\mathrm{n}$ \\
\hline Instrução pai & $\begin{array}{l}\text { Até Ensino Fundamental } \\
\text { Ensino Médio }\end{array}$ & $\begin{array}{l}14 \\
1\end{array}$ \\
\hline Total & $\begin{array}{l}\text { Superior ou Pós-graduação } \\
\text { Não sei }\end{array}$ & $\begin{array}{l}1 \\
4 \\
20\end{array}$ \\
\hline Instrução mãe & $\begin{array}{l}\text { Até Ensino Fundamental } \\
\text { Ensino Médio } \\
\text { Superior ou Pós-graduação } \\
\text { Não sei }\end{array}$ & $\begin{array}{l}14 \\
3 \\
2 \\
1 \\
20\end{array}$ \\
\hline Ocupação pai & $\begin{array}{l}\text { Profissional liberal ou atividade } \\
\text { profissional com exigência formativa } \\
\text { elevada. } \\
\text { Serviços administrativos, comércio, } \\
\text { serviços técnicos e demais ocupações } \\
\text { que exigem formação escolar mediana. } \\
\text { Trabalho manual, produção de bens e } \\
\text { serviços industriais e atividades } \\
\text { profissionais que exigem baixa } \\
\text { exigência formativa. } \\
\text { Outros }^{3}\end{array}$ & $\begin{array}{l}15 \\
5 \\
20\end{array}$ \\
\hline Ocupação mãe & $\begin{array}{l}\text { Profissional liberal ou atividade } \\
\text { profissional com exigência formativa } \\
\text { elevada. } \\
\text { Serviços administrativos, comércio, } \\
\text { serviços técnicos e demais ocupações } \\
\text { que exigem formação escolar mediana. } \\
\text { Trabalho manual, produção de bens e } \\
\text { serviços industriais e atividades } \\
\text { profissionais que exigem baixa } \\
\text { exigência formativa. } \\
\text { Outros }\end{array}$ & $\begin{array}{l}15 \\
1\end{array}$ \\
\hline Total & & 20 \\
\hline
\end{tabular}

No que se refere à renda familiar mensal, nota-se uma maior distribuição das famílias entre as faixas que variam de um a até cinco salários mínimos ${ }^{4}$. Estes valores, quando divididos pelo número de pessoas que compõe cada grupo familiar tendo em vista o cálculo da renda per capita, indicam o mesmo perfil econômico, uma vez que níveis mais elevados de rendimento das famílias correspondiam a um número maior de integrantes. Assim, a relação entre renda mensal familiar e seus membros, caracteriza a prevalência de uma renda per capita familiar de até um salário mínimo. As análises são visualizadas na Tabela 2.4.

\footnotetext{
${ }^{3}$ A categoria outros foi aplicada nos casos em que o registro realizado pelo aluno não informou a ocupação desempenhada e nas situações cuja informação era inconsistente.

${ }^{4}$ Para fins de cálculo da renda familiar, deve-se considerar o valor padrão do salário mínimo referente ao ano de 2013, momento em que o levantamento de dados foi realizado, definido em $\mathrm{R} \$ 678,00$.
} 
Tabela 2.4 - Distribuição dos respondentes Uniban/Anhanguera quanto à renda familiar mensal em salários mínimos, número de pessoas sustentadas e renda familiar per capita.

\begin{tabular}{lll}
\hline Variáveis & Categorias & $\mathbf{n}$ \\
\hline Renda familiar mensal & Até 1 s.m. & 1 \\
& 1 até 2 s.m. & 8 \\
& 2 até 3 s.m. & 5 \\
& 3 até 5 s.m. & 4 \\
& 5 até 7 s.m. & 1 \\
& 7 até 10 s.m. & 0 \\
& 10 até 14 s.m. & 1 \\
Total & & 20 \\
& & \\
Pessoas sustentadas pela renda declarada & Uma & 3 \\
& Duas & 4 \\
& Três & 3 \\
& Quatro & 5 \\
Total & Cinco & 3 \\
& Seis & 0 \\
Renda familiar per capita & Sete & 1 \\
& Oito ou mais & 1 \\
& & 20 \\
& & 13 \\
& Até 1 s.m. & 13 \\
& 1 até 2 s.m. & 0 \\
& 2 até 4 s.m. & 0 \\
& 4 ou mais s.m. & 1 \\
& & 20 \\
\hline
\end{tabular}

Indagadas sobre o desenvolvimento de atividade remunerada durante a graduação, do conjunto de alunas estudadas (vide Tabela 2.5), 16 responderam afirmativamente à questão, havendo equilíbrio na divisão entre os regimes de dedicação parcial e integral. Deste grupo, 13 já trabalhavam na área da educação principalmente como estagiárias e docentes. Considerando a renda individual declarada pelas estudantes, pode-se afirmar que a faixa salarial predominante é a que varia entre um e dois salários mínimos, independente da ocupação desempenhada. $\mathrm{O}$ cruzamento dos rendimentos individuais com as atividades desenvolvidas pelas estudantes indica que o salário pago às alunas que já atuam como docentes varia de um a três salários mínimos, valor este que não se distancia significativamente do que é pago para as alunas na condição de estagiárias. 
Tabela 2.5 - Distribuição dos respondentes Uniban/Anhanguera quanto a atividade ocupacional, rendimentos e regime de trabalho durante a graduação.

\begin{tabular}{|c|c|c|}
\hline Variáveis & Categorias & $\mathrm{n}$ \\
\hline Ocupação & $\begin{array}{l}\text { Atividades não educacionais: analista de } \\
\text { condomínios, assistente fiscal, auxiliar de limpeza } \\
\text { Docência } \\
\text { Estágio } \\
\text { Trabalho administrativo em escola }\end{array}$ & $\begin{array}{l}3 \\
5 \\
7 \\
1 \\
16\end{array}$ \\
\hline Rendimentos & $\begin{array}{l}\text { Não tenho rendimentos } \\
\text { Até } 1 \mathrm{~s} . \mathrm{m} . \\
\text { Entre } 1 \text { e } 2 \mathrm{~s} . \mathrm{m} . \\
\text { Entre } 2 \text { e } 3 \mathrm{~s} . \mathrm{m} . \\
\text { Entre } 3 \text { e } 5 \mathrm{~s} . \mathrm{m} .\end{array}$ & $\begin{array}{l}1 \\
2 \\
8 \\
4 \\
1 \\
16\end{array}$ \\
\hline $\begin{array}{l}\text { Rendimentos professoras } \\
\text { Total }\end{array}$ & $\begin{array}{l}\text { Não declarou } \\
\text { Entre } 1 \text { e } 2 \text { s.m. } \\
\text { Entre } 2 \text { e } 3 \text { s.m. }\end{array}$ & $\begin{array}{l}1 \\
2 \\
2 \\
5\end{array}$ \\
\hline $\begin{array}{l}\text { Rendimentos estagiárias } \\
\text { Total }\end{array}$ & $\begin{array}{l}\text { Até } 1 \text { s.m. } \\
\text { Entre } 1 \text { e } 2 \text { s.m. } \\
\text { Entre } 2 \text { e } 3 \text { s.m. }\end{array}$ & $\begin{array}{l}2 \\
4 \\
1 \\
7\end{array}$ \\
\hline $\begin{array}{l}\text { Regime de trabalho } \\
\text { Total }\end{array}$ & $\begin{array}{l}\text { Parcial } \\
\text { Integral }\end{array}$ & $\begin{array}{l}7 \\
9 \\
16\end{array}$ \\
\hline
\end{tabular}

Dentre os diferentes recursos utilizados por estas estudantes para o custeio de sua formação universitária, destaca-se pela maior recorrência, o Fundo de Financiamento Estudantil (FIES) (Tabela 2.6). O FIES ${ }^{5}$ é um programa do Ministério da Educação que financia os custos do curso de graduação de estudantes matriculados em instituições privadas, avaliadas positivamente pelo MEC no Sistema Nacional de Avaliação da Educação Superior (SINAES). Desde 2010, o agente operador do programa é o Fundo Nacional de Desenvolvimento da Educação (FNDE), que estabeleceu a taxa efetiva de juros em 3,4\% ao ano para todos os cursos. A proposta do Programa é que durante o curso o aluno pague, a cada três meses, o valor máximo de R \$ 50,00. Esse mesmo valor e prazo serão mantidos após a conclusão do curso, pelo período de um ano e meio. Depois deste período, o saldo devedor será parcelado em até três vezes o período financiado do curso, acrescido de doze meses. Em 2001, a Lei $n^{\circ} 10.260$ estabeleceu que o FIES poderá abater $1 \%$ do saldo devedor consolidado dos estudantes matriculados em cursos de Licenciatura, Normal Superior ou Pedagogia que sejam também professores em efetivo exercício na rede pública de educação básica, com jornada mínima de vinte horas

5 As informações sobre o FIES foram consultadas no portal do MEC no seguinte endereço $<$ http://sisfiesportal.mec.gov.br/>. Acesso em: 22 set. 2013. 
semanais. Apesar deste estímulo, nenhuma das estudantes investigadas que participam deste programa está enquadrada nesta condição, já que as duas alunas-docentes são funcionárias de instituições de caráter privado.

Tabela 2.6 - Distribuição de bolsa de estudos ou financiamento estudantil entre os respondentes da Uniban/Anhanguera.

\begin{tabular}{lll}
\hline Variáveis & Categorias & $\mathbf{n}$ \\
\hline Bolsa de estudos ou financiamento estudantil & PROUNI & 2 \\
& FIES & 8 \\
& Bolsa institucional - integral ou & \\
Total & parcial & 2 \\
\hline
\end{tabular}

Além do FIES, há dois casos de estudantes beneficiárias do Programa Universidade Para Todos (PROUNI). Institucionalizado pelo Governo Federal em 2005, o programa do Ministério da Educação tem por finalidade conceder bolsas de estudo integrais ou parciais em cursos de graduação e também nos cursos sequenciais de formação específica, em instituições de ensino superior privadas. Dirigido aos estudantes que cursaram o ensino médio na rede pública ou na rede particular (neste caso, na condição de bolsistas integrais), que tenham renda familiar per capita máxima de três salários mínimos, a seleção dos candidatos se dá pelas notas obtidas no Exame Nacional do Ensino Médio (ENEM). Para os estudantes que obtiveram a bolsa parcial, sugere-se a possibilidade de articular o PROUNI com o Fundo de Financiamento ao Estudante do Ensino Superior (FIES), o qual permite o financiamento de até $100 \%$ do valor da mensalidade não coberta pelo programa. No grupo de alunas investigado, uma contou com a bolsa PROUNI na modalidade integral, enquanto a beneficiária da bolsa parcial não procurou o financiamento estudantil para o pagamento do valor descoberto pelo programa.

Tanto o FIES quanto o PROUNI caracterizam-se como programas do governo federal que objetivam ampliar as oportunidades de acesso ao ensino superior das classes populares, as quais não reúnem condições financeiras para o custear sua formação universitária. $O$ fato de mais da metade das alunas investigadas utilizarem algum tipo de recurso para seu ingresso e manutenção no ensino superior, em uma instituição cuja mensalidade era reconhecida por seus valores populares, contribui para reforçar a sua identificação com as camadas populares. Assim, os dados relativos ao custeio da formação universitária dessas alunas estão associados aos apresentados anteriormente sobre a trajetória escolar das mesmas, em que as marcas de uma condição desfavorecida fizeram-se presentes. Com uma trajetória escolar marcada pela frequência a instituições públicas de ensino, as desvantagens sociais e escolares experimentadas 
na história de vida destas alunas envolveu a formação no período noturno, aliada ao trabalho em jornada integral já durante o ensino médio, além de situações de afastamento da escola, cuja consequente distorção idade-série foi solucionada por meio da frequência a cursos mais aligeirados na modalidade Educação de Jovens e Adultos.

Para essas alunas, o acesso ao ensino superior não foi uma consequência natural dada após a finalização do ensino médio. Essa constatação dá-se sobretudo pela faixa etária mais elevada que as representa e pelo longo intervalo existente entre o encerramento do ensino médio e o ingresso na graduação em Pedagogia. Enquanto nos cursos mais disputados nos vestibulares de universidades públicas, suas vagas são costumeiramente ocupadas por candidatos mais jovens (PEREIRA, 2006), entre essas estudantes a idade elevada indica o distanciamento dos privilégios sociais experimentados pelos primeiros. De acordo com Bourdieu (2013), o reconhecimento do êxito escolar manifesto pela pouca idade dos alunos ingressantes nas instituições de elevado valor social é justificado ideologicamente pela posse de virtudes pessoais por parte destes, tais como inteligência, talento e dom. Esta forma de compreensão da excelência escolar termina por naturalizar as vantagens sociais vividas por esses alunos, decorrentes de sua inserção em ambientes mais favorecidos do ponto de vista econômico e cultural, legitimando as hierarquias escolares, sem considerar as hierarquias sociais que as produziram.

A privação econômica e cultural de origem destas alunas expressa pela renda per capita familiar mensal de até um salário mínimo, ao mesmo tempo que seus pais possuem baixo nível de escolaridade, repercutiu significativamente na trajetória formativa dessas estudantes. Enquanto o modesto capital econômico da família reduziu as possibilidades de investimentos voltados para a ampliação da formação cultural, do mesmo modo que aumentou as dificuldades de vida que as restrições financeiras produzem, a limitada formação cultural familiar empobreceu o volume de conhecimentos, informações, competência linguística e atitudes assimilados via transmissão doméstica do capital cultural, os quais interferiram no rendimento destas alunas ao ingressarem no espaço escolar. Esta condição social originária das respondentes agiu como mecanismo de eliminação durante todo seu percurso formativo, dificultando uma formação escolar de longa duração, que se completaria no acesso ao ensino superior (BOURDIEU, 2013).

Em estudo realizado com universitários de origem popular, Zago (2006) destaca o reconhecimento por parte dos mesmos de que o ingresso nas instituições de ensino mais disputadas requer uma formação escolar anterior qualificada. Em alguns casos, diante da 
admissão de lacunas em seu processo formativo, muitos jovens desistem de certas universidades, sem ao menos prestar o vestibular. Outros procuram os cursinhos prévestibulares com o intuito de ampliar seu nível de formação e, consequentemente, suas condições de acesso, estratégia comum no Brasil desde a década de 1970 (BORGES; CARNIELLI, 2005). Entretanto, no caso das alunas investigadas, a frequência ao cursinho foi mínima. Uma das hipóteses para esta constatação pode ser a de que essas jovens não aspiravam acessar o ensino superior, ou mais especificamente, o ensino superior público. A ausência desse interesse pode ser explicada pela falta de informações sobre o vestibular e sobre a formação universitária $^{6}$, ou ainda, pelo fato das condições de vida experimentadas por essas alunas terem produzido ambições tão realistas acerca do acesso ao ensino superior, que excluíram delas o desejo de concretizar aquilo que entendiam como impossível (BOURDIEU, 2013).

Por outro lado, a posterior identificação da oportunidade de ingresso no ensino superior deu-se para estas alunas quando as mesmas destinaram-se a uma instituição que se adequava às suas condições objetivas de existência, por um conjunto de aspectos específicos. Inicialmente destaca-se a facilidade existente no ingresso para o início do curso, uma vez que o processo seletivo empregado pela universidade não realizava uma triagem real dos candidatos. Nesse sentido, a ausência de uma formação qualificada prévia deixou de se constituir como um obstáculo concreto para a continuidade de seus estudos. Outro aspecto que merece ser mencionado diz respeito ao valor da mensalidade, bastante baixo em relação às demais instituições privadas existentes, comprometendo menos o já diminuto rendimento familiar da estudante. Por fim, a possibilidade de concluir o curso superior dentro de um período de três anos apenas reduziu o volume de investimento financeiro ao mesmo tempo que abreviou a espera pelos supostos ganhos, materiais ou simbólicos, envolvido na posse do diploma universitário.

Considerando-se a hierarquia social vinculada aos estabelecimentos de ensino, a UNIBAN-Anhanguera distancia-se dos espaços de formação universitária preservados, destinados a estudantes oriundos de famílias com elevado capital econômico e cultural, cujas vagas são conquistadas após a aprovação dos candidatos em processos seletivos bastante concorridos. Contrariamente, a universidade em questão representa a típica entidade de ensino superior privado que se multiplicou precipitadamente nos bairros de diferentes cidades,

\footnotetext{
${ }^{6}$ Ao longo dos anos em que dediquei-me à docência nesta instituição, inúmeras vezes os alunos perguntaram o nome da universidade onde eu havia concluído meu curso de Pedagogia. Ao ouvirem "USP" como resposta, poucos reconheciam a instituição e ficavam surpreendidos ao descobrirem a existência de cursos de Pedagogia gratuitos.
} 
admitindo como alunos representantes das classes populares, portadores de uma empobrecida bagagem cultural, tal como será demonstrado ainda neste capítulo.

O decurso histórico da expansão do setor privado na educação superior ${ }^{7}$, cujo crescimento continuamente superou aquele experimentado pelos estabelecimentos públicos, aliado às recentes políticas federais voltadas para o financiamento estudantil e concessão de bolsas de estudo, permitiu o ingresso no meio universitário das categorias sociais que, em termos históricos, estavam quase totalmente excluídas desse espaço de formação. O lucro destas instituições privadas residiria justamente aí, na promoção do atendimento de uma população adulta, trabalhadora, vinculada às classes populares, cujo acesso à educação superior, há muito represado, seria possibilitado por meio do pagamento de mensalidades de baixo custo.

$\mathrm{O}$ rápido crescimento da UNIBAN-Anhanguera, em particular, deveu-se ao movimento de entrada do capital financeiro na educação. No início da primeira década dos anos 2000, a identificação da expansão acelerada do ensino superior atraiu investidores interessados na obtenção de lucros, a partir da aquisição de cotas em fundos de investimento especializados no setor educacional. Em 2007, a Anhanguera Educacional abriu seu capital na bolsa de valores, fator que favoreceu significativamente seu processo de ampliação ${ }^{8}$. Entretanto, neste movimento de mercantilização da educação, tal como anunciado por Oliveira (2009), a finalidade maior de ampliação dos lucros termina por afetar a qualidade do trabalho pedagógico desenvolvido. Estratégias de racionalização da gestão levam à substituição de aulas ministradas pelos docentes, contabilizadas na grade curricular, por atividades a distância, estudos na biblioteca ou laboratório de informática, sem a presença dos mesmos. Essa prática, associada a formação de classes com diferentes turmas agrupadas, enquanto a jornada de trabalho docente no período noturno é encerrada às 22 horas, a fim de evitar o pagamento do adicional noturno, reduz significativamente o número de professores contratados, as despesas com a folha de pagamento e, consequentemente, as oportunidades de interlocuções formativas entre professores e alunos.

Tanto a popularização do acesso, quanto as condições formativas proporcionadas pela UNIBAN-Anhanguera, repercutem no valor simbólico do diploma que seus alunos terminam por adquirir. Trata-se de uma instituição popular para estudantes das classes populares, cuja aparente democratização formativa anunciada constitui, na realidade, apenas um processo de

\footnotetext{
${ }^{7} \mathrm{O}$ processo de expansão do ensino superior brasileiro foi discutido no capítulo "Formação de professores das séries iniciais e o curso de Pedagogia no Brasil", desta pesquisa.

8 Informações acerca do processo de expansão da UNIBAN-Anhanguera são apresentadas no capítulo "Procedimentos metodológicos e as instituições investigadas", desta tese.
} 
reprodução da estrutura social, no interior da estrutura educacional. Desse modo, estudantes originários de diferentes classes sociais ocupam instituições de ensino superior desiguais e, no interior das mesmas, frequentam cursos de graduação distintos, de acordo com o nível de raridade e valor social do diploma.

\subsection{REALIDADE E UTILITARISMO - O POSSÍVEL COMO ORIENTADOR DAS PRÁTICAS CULTURAIS}

Para uma compreensão das práticas culturais das alunas aqui investigadas, é fundamental considerar sua condição social de origem. Retomando os dados anteriormente apresentados acerca do perfil socioeconômico do grupo de respondentes oriundas da UNIBANAnhanguera, é possível caracterizá-las como estudantes cuja faixa etária é mais elevada e que vivenciaram uma trajetória escolar pouco privilegiada. Egressas da rede pública de ensino, frequentaram o ensino médio noturno, enquanto dedicavam-se ao trabalho em jornadas de tempo integral. Seus pais possuem baixo nível de instrução, atingindo no máximo o ensino fundamental completo e desempenham ocupações marcadas pelo trabalho manual. Em termos de renda, estas alunas pertencem a famílias de baixo poder aquisitivo, com rendimento per capita mensal de até um salário mínimo. Por fim, o ingresso no ensino superior foi tardio e dependeu, para mais da metade das alunas, da obtenção de algum tipo de auxílio para o custeio das mensalidades. Todos esses indicadores reunidos, tanto de ordem econômica quanto os de formação familiar e escolar, terminaram por afetar suas disposições em relação à cultura.

De acordo com Bourdieu (2007), o consumo dos bens culturais pelos agentes tem relação significativa com seu nível de instrução. Assim, as práticas culturais e as preferências em termos de música, literatura, dentre outras manifestações, são afetadas pelo processo formativo vivenciados tanto no meio familiar quanto no espaço escolar. Entretanto, a capacidade de relacionar-se legitimamente com a cultura - nobreza cultural - resulta de uma formação cultural precoce, dada no ambiente doméstico.

Ao questionar a ideologia envolvida na crença da existência de uma sensibilidade inata para a apreciação artística, o autor destaca o processo de formação cultural exercido espontaneamente pelo meio familiar, em que este tipo de conhecimento se faz originalmente presente. Para tanto, o nível cultural dos pais e até da família extensa deve ser considerado em seus efeitos sobre a formação de seus descendentes: quanto mais elevado o nível cultural 
familiar, maiores os ganhos nos resultados escolares; nas práticas e conhecimentos culturais, seja em matéria de teatro, literatura ou qualquer outro tipo de manifestação.

O convívio precoce com a cultura, por meio da socialização primária, favorece uma aprendizagem involuntária que leva à posse de uma competência cultural desenvolta e genuína, sendo esta a expressão do capital cultural em seu estado incorporado. São saberes absorvidos integral e dissimuladamente, produtores de um certo modo de ser e de um conjunto de esquemas de percepção (habitus culto), os quais favorecem a apreciação simbólica dos bens materiais objetivados.

O domínio da cultura socialmente entendida como legítima pelas classes dominantes não só conduz ao êxito escolar, uma vez que a escola pressupõe em seus alunos a posse desse tipo de saber, mas também torna possível ao agente a capacidade de fruir livremente das produções culturais, a partir de seus interesses, considerando-se sua própria classificação entre o que merece e não merece ser visto. Cabe ressaltar que os interesses culturais têm relação com a posição de classe ocupada pelo agente no interior da estrutura social. Assim, deve-se entender que as preferências culturais - longe de expressarem uma manifestação pura e simples do gosto pessoal - são significativamente impactadas pela posse do capital econômico e cultural por parte dos agentes.

Há, portanto, vantagens e desvantagens culturais experimentadas pelas diferentes classes sociais. Quanto menor o capital cultural familiar, menor a proximidade do agente com os bens culturais objetivados, reduzindo assim sua capacidade de fruição das manifestações de cultura socialmente legitimadas. Além disso, o capital econômico também influencia no acesso aos bens culturais e nas práticas que o seu consumo envolve. O baixo capital econômico reduz as possibilidades do contato precoce com o capital cultural no seu estado objetivado, ou seja, a apropriação material de bens culturais, do mesmo modo que afeta as possibilidades de consumo cultural em situações futuras. Paralelamente, as condições econômicas dos agentes terminam por influenciar sua trajetória formativa escolar, seja pelo tipo de escola frequentada, seja pela posse de tempo disponível para uma dedicação mais intensa aos estudos, como também afeta o tempo de permanência do indivíduo no espaço escolar, sendo menor entre as classes populares a duração de seu percurso formativo institucionalizado. Daí, segue-se a importância de conhecer a condição socioeconômica e cultural dos agentes, responsáveis por alocá-los em uma determinada posição no espaço social e que terminam por afetar suas práticas, seu estilo de vida, suas percepções sobre o mundo, ou tal como conceitua Bourdieu, seu habitus. 
Com o intuito de traçar o perfil das formandas pesquisadas nesta instituição, para além de sua origem socioeconômica, foram investigadas as atividades mais frequentemente desenvolvidas por estas alunas, tendo em vista identificar o tipo e a ocorrência de suas práticas culturais. A observação dos resultados obtidos indica que as atividades realizadas com maior recorrência em meio ao grupo investigado são: ouvir música; dedicar-se aos cuidados com a casa, assistir televisão, ir ao shopping e à igreja, além de utilizar parte de seu tempo para o descanso.

Restrições de ordem financeira justificam em parte tal comportamento, que terminam também por limitar o tempo livre disponível para ser dedicado às atividades de lazer. Quando não estão trabalhando ou estudando, o tempo passa a ser utilizado para a realização de tarefas cotidianas que envolvem, por exemplo, o cuidado com a casa. De acordo com Bourdieu (2007, p.350), as restrições econômicas e sociais "impõe um gosto de necessidade" que implica uma forma de adaptação às condições objetivas de vida, delimitando as práticas populares a gostos marcados pela simplicidade e ações circunscritas pelo pragmático e funcional. O que justifica neste grupo o fato de, na ocorrência horas excedentes livres, estas serem utilizadas para o descanso ou para a realização de atividades praticadas no ambiente doméstico, tais como ouvir música e assistir televisão. As frequência de desenvolvimento das práticas culturais são apresentadas na Tabela 2.7. 
Tabela 2.7 - Atividades mais frequentemente realizadas no tempo livre pelas respondentes da Uniban/Anhanguera.

\begin{tabular}{|c|c|c|}
\hline Variáveis & Categorias & $\mathrm{n}$ \\
\hline \multirow[t]{4}{*}{ Ouvir música } & Frequentemente & 16 \\
\hline & Ocasionalmente & 3 \\
\hline & Raramente & 1 \\
\hline & Nunca & 0 \\
\hline Total & & 20 \\
\hline \multirow[t]{4}{*}{ Cuidados com a casa } & Frequentemente & 16 \\
\hline & Ocasionalmente & 1 \\
\hline & Raramente & 3 \\
\hline & Nunca & 0 \\
\hline Total & & 20 \\
\hline \multirow[t]{4}{*}{ Leitura } & Frequentemente & 15 \\
\hline & Ocasionalmente & 2 \\
\hline & Raramente & 2 \\
\hline & Não resposta & 1 \\
\hline Total & & 20 \\
\hline \multirow[t]{5}{*}{ Televisão } & Frequentemente & 12 \\
\hline & Ocasionalmente & 4 \\
\hline & Raramente & 2 \\
\hline & Nunca & 0 \\
\hline & Não resposta & 2 \\
\hline Total & & 20 \\
\hline \multirow[t]{5}{*}{ Shopping } & Frequentemente & 11 \\
\hline & Ocasionalmente & 7 \\
\hline & Raramente & 1 \\
\hline & Nunca & 0 \\
\hline & Não resposta & 1 \\
\hline Total & & 20 \\
\hline \multirow[t]{5}{*}{ Igreja } & Frequentemente & 11 \\
\hline & Ocasionalmente & 2 \\
\hline & Raramente & 6 \\
\hline & Nunca & 0 \\
\hline & Não resposta & 1 \\
\hline Total & & 20 \\
\hline \multirow[t]{4}{*}{ Descansar } & Frequentemente & 11 \\
\hline & Ocasionalmente & 2 \\
\hline & Raramente & 6 \\
\hline & Nunca & 1 \\
\hline Total & & 20 \\
\hline
\end{tabular}

A única modalidade de lazer cultural indicada como frequentemente realizada pela maior parte do grupo investigado foi a prática da leitura. Em termos de consumo de informação, há uma divisão muito equilibrada entre as alunas que leem revistas muito e regularmente $(8 / 20)$ e as que leem pouco $(9 / 20)^{9}$. Dentre os títulos dos periódicos mais mencionados temos a revista Veja e a Nova Escola, cada uma delas com sete indicações. A menção à revista Veja pode ser justificada, em parte, pela ampla circulação com que ela conta no cenário editorial brasileiro, sendo ela a revista mais lida no país de acordo com o Instituto Verificador de Circulação (IVC). No caso da revista Nova Escola, destaca-se novamente o "gosto de necessidade" que impõe às

\footnotetext{
${ }^{9}$ Somente três alunas afirmaram não ler nenhum tipo de revista.
} 
alunas uma relação prática com a cultura, buscando em revistas especializadas a apropriação de informações úteis ao seu cotidiano profissional.

Em relação aos jornais, as alunas demonstraram um grande desinteresse, já que dezessete afirmaram ler pouco ou não ler esse tipo de fonte de informação, enquanto apenas duas alunas declararam lê-los com regularidade. No que se refere à leitura de jornais, Bourdieu (2007) aponta que o interesse por esta fonte de informação aumenta de acordo com o capital cultural incorporado. Assim, os leitores de jornais de grande circulação são geralmente detentores do diploma universitário, aproximando-se, ao mesmo tempo, das hierarquias sociais mais elevadas. Contrariamente, a leitura de jornais regionais ou tal como Bourdieu denomina, “jornal para todos”, é mais presente entre as classes populares, proprietárias de um capital cultural e econômico menos expressivo. Este fenômeno, observado por Bourdieu na sociedade francesa, também se fez presente entre as alunas aqui investigadas, já que uma dentre as únicas duas alunas que afirmaram realizar essa prática com certa regularidade, indicou como objeto de leitura os jornais "do trem e do metro", enquanto a segunda apontou o nome da revista Veja como seu "jornal” mais lido. No caso desta última, seu equívoco pode ser interpretado como a expressão de sua pouca familiaridade com este tipo de fonte de informação, engrossando assim o número de formandas que não estão habituadas a esta prática cultural.

A respeito da leitura de livros, dez alunas afirmaram pouco dedicar do seu tempo a esse hábito, enquanto a outra metade da turma indicou ler muito e regularmente. Frente ao pedido de informarem o título do último livro lido, três alunas admitiram não recordar, enquanto outras três registraram títulos que não foram identificados, consequência da imprecisão de seus apontamentos. Respostas ambíguas também foram utilizadas como recurso para substituir o título do último livro lido, tal como exemplifica o registro a seguir: "Livros do curso, literatura, didática...”. A somatória destes casos totalizou oito alunas que não conseguiram evocar o nome do último livro lido. Por outro lado, dentre os títulos lembrados e corretamente mencionados é possível identificar maior recorrência de obras estrangeiras que ocuparam a lista dos mais vendidos. Dentre as publicações nacionais, somente dois clássicos da literatura foram mencionados. 
Tabela 2.8 - Listagem dos livros lidos recentemente pelas respondentes da Uniban/Anhanguera.

\begin{tabular}{lll}
\hline Variáveis & Categorias & $\mathbf{n}$ \\
\hline Livros estrangeiros & A cabana (William P. Young) & 1 \\
& Cinquenta tons de cinza (Erika L. James) & 2 \\
& O caçador de pipas (Khaled Hosseini) & 1 \\
& Quando ela se foi (Harlan Coben) & 1 \\
Livros nacionais & O seminarista (Bernardo Guimarães) & 1 \\
& O Zahir (Paulo Coelho) & 1 \\
& Vidas Secas (Graciliano Ramos) & 1 \\
Educação & O relatório de avaliação na educação infantil (Cristina A. Colasanto) & 1 \\
& Letramento e alfabetização: as muitas facetas (Magda Soares) & 1 \\
& Que raio de professora sou eu (Fanny Abramovich) & 1 \\
Religioso & Esmeralda (Zibia Gasparetto) & 1 \\
Total & & 12 \\
\hline
\end{tabular}

Do mesmo modo que a leitura de jornais, os livros de literatura apontados pelas estudantes como objeto de atenção mais recente (Tabela 2.8) passam por uma classificação de "leitura para todos", ou seja, o texto das obras possui como característica uma estrutura simples e acessível, que demanda uma leitura descomplicada e ligeira. Trata-se de obras de grande difusão, sucesso de vendagem, cuja divulgação foi favorecida pela mídia, tornando-os conhecidos do grande público, fato que pode ter facilitado a rememoração de seus títulos. De acordo com Bourdieu (2007), o interesse atribuído aos diferentes tipos de leitura - "leitura para todos" ou "leituras legítimas" - varia de acordo com a posse do capital cultural. Assim, quanto maior a legitimidade cultural da obra tomada como objeto de interesse do agente, maior será o volume do capital cultural por ele detido.

Os hábitos de leitura demonstrados pelas alunas reforçam mais uma vez a constatação de que as mesmas possuem um baixo capital cultural incorporado, condição esta que termina por empobrecer suas práticas culturais. Daí decorre o fato das atividades realizadas com menor frequência no tempo livre serem justamente as que exigem do receptor uma capacidade de apreensão cultural mais elevada, tais como o acesso ao teatro, concertos e museus, assim como demonstra a Tabela 2.9: 
Tabela 2.9 - Atividades culturais e de lazer realizadas com pouca frequência pelos respondentes da Uniban/Anhanguera.

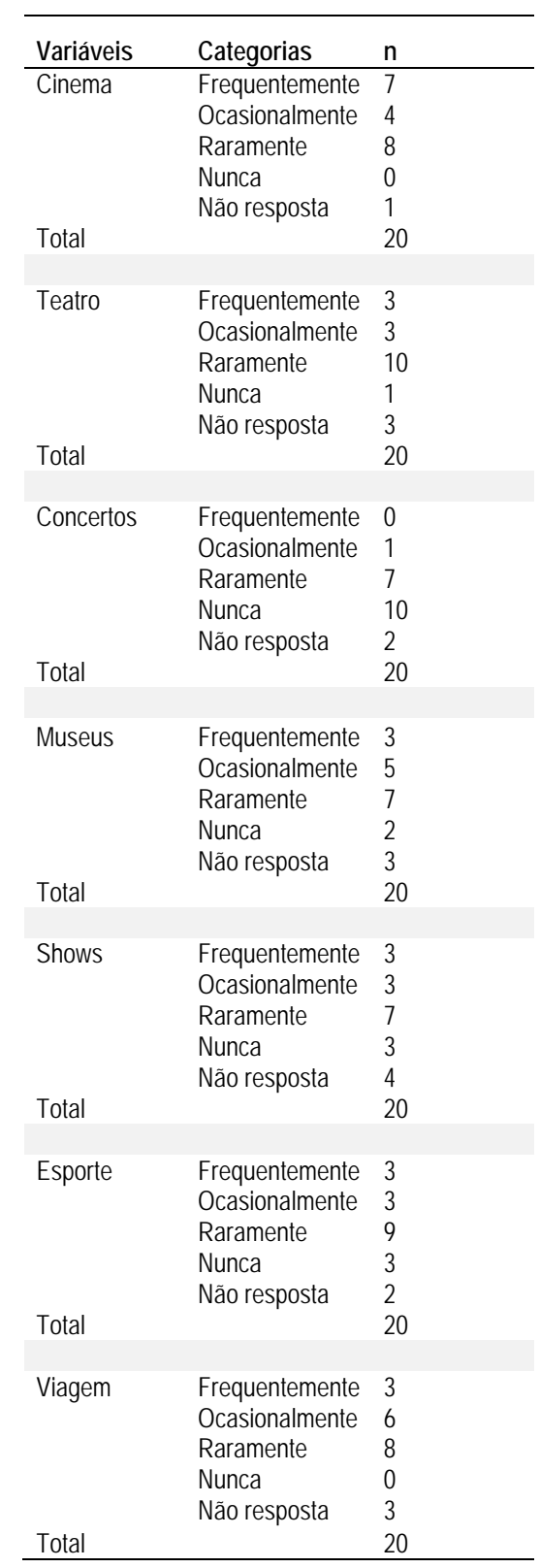

Ainda que o cinema não se constitua como uma arte da cultura erudita, é relevante o fato de doze estudantes não conseguirem informar o nome do último filme por elas assistido. As poucas alunas participantes da pesquisa que o fizeram tenderam a apontar títulos fora de cartaz há alguns anos (Tabela 2.10), tais como "O caçador de pipas" (2007) e "Avatar" (2009), ou filmagens do ano anterior à pesquisa, dentre as quais podemos indicar: "A era do gelo 4" (2012) e "Os penetras" (2012). Somente três alunas conseguiram indicar títulos do ano de 2013 ("O grande Gatsby"; "Os Croods" e "Velozes e Furiosos 6"), dado que contradiz a informação prestada pelas sete alunas que afirmaram ser esta uma prática frequente em suas vidas. Por fim, 
o filme citado "A bela adormecida", cuja produção cinematográfica do conto ocorreu em 1959, exemplifica a tentativa de dissimular o fato desta prática cultural não fazer parte do cotidiano destas alunas.

Tabela 2.10 - Listagem do último filme visto no cinema pelos respondentes da Uniban/Anhanguera.

\begin{tabular}{|c|c|c|}
\hline & Títulos mencionados & $\begin{array}{l}\text { Não souberam } \\
\text { informar }\end{array}$ \\
\hline Filme & $\begin{array}{c}\text { A bela adormecida; A era do gelo } 4 \text { (2012); Avatar (2009); O caçador } \\
\text { de pipas (2008); O grande Gatsby (2013); Os Croods (2013); Os } \\
\text { penetras (2012); Velozes e Furiosos } 6 \text { (2013). }\end{array}$ & 12 alunas \\
\hline
\end{tabular}

Quanto ao teatro, é significativo o número de estudantes que raramente ou nunca o frequentam. A observação dos nomes da última apresentação acompanhada pelos alunos indica a ocorrência de peças infantis (“A menina feliz”, “Cocoricó”); um musical (“O Rei Leão”); uma comédia de improviso ("Labutaria") e um drama ("Pandora"). A preferência pelas temáticas leves exemplificadas pelas comédias, musicais, peças infantis, assim como ocorreu na seleção dos filmes e livros - demonstra que as atividades culturais destas alunas voltam-se para aquelas que pouco exigem em termos de investimento cultural, requerendo apenas uma participação "passiva e ausente", tal como Bourdieu (2007) se refere ao consumo dos produtos culturais de grande difusão, ou seja, produzidos para divertir e atingirem um grande sucesso comercial.

Bourdieu (2007, 2013) destaca também a existência de condições objetivas que produzem o desinteresse manifesto das classes populares pela cultura legítima. Entre eles, podemos indicar os custos envolvidos nas práticas culturais. Assim, as modalidades de consumo cultural variam de acordo com os custos econômicos implicados na sua prática: "a frequência do teatro depende não só do nível de instrução, mas igualmente da remuneração" (BOURDIEU, 2007, p. 111). Ao mesmo tempo, o autor entende haver relação entre a localização da moradia e as atividades culturais realizadas, considerando-se as vantagens associadas a residências que se situam nas proximidades de regiões que contam com uma oferta cultural mais numerosa.

O campus em estudo da UNIBAN-Anhanguera localiza-se no bairro do Morumbi e foi possível notar que seu público mora prioritariamente na mesma região da universidade: a zona sul de São Paulo (18/20). Dentre os bairros ocupados foram mencionados Campo Limpo, Capão Redondo, Cidade Ademar, Cidade Dutra, Grajaú, Jabaquara e Jardim Ângela. Com exceção do bairro do Jabaquara e Campo Limpo, é importante destacar que nessas localidades inexistem equipamentos culturais como cinemas, teatros e museus, sendo mais comum nesses bairros a 
presença de bibliotecas e casas de cultura. A ausência desses equipamentos culturais nas imediações da residência dos alunos pode ser tomada como parte da explicação que justificaria o fato das práticas de ir ao cinema, teatro e museu serem ocasionais ou raras em meio a este grupo. Porém, Bourdieu não toma as limitações objetivas de ordem econômica e as condições de moradia dos agentes como justificativas isoladas para as suas práticas culturais. Estas duas condições são tomadas como desvantagens que, associadas ao capital cultural, colaboram na constituição de suas disposições em relação à cultura.

No que se refere aos museus, apesar da frequência ter sido indicada pelas alunas como prática incomum, nota-se que ainda assim uma pequena parcela foi capaz de indicar o nome dos seus locais preferidos, destacando-se o Museu da Língua Portuguesa, com quatro menções e o Museu Paulista com duas referências. O esforço por não deixar a resposta da pergunta em branco evidenciou novamente a falta de familiaridade das alunas com este espaço cultural, uma vez que respostas vagas, confusas e equivocadas foram utilizadas com a intenção de informar o museu que mais gostaram de visitar, tais como "foi a casa do Dom Pedro", quando certamente a aluna desejou mencionar o "Museu imperial"; "MAN", no lugar de MAM - o Museu de Arte Moderna e "Grande família", sendo neste último caso impossível identificar a real intenção da estudante.

Do mesmo modo como ocorre nas demais práticas culturais legitimadas, a frequência a museus aumenta consideravelmente à medida que o nível de instrução é mais elevado (Bourdieu, 2007a). Assim, por mais que os museus estejam disponíveis ao público em geral, o proveito do conteúdo que lá se faz presente depende de aprendizagens anteriores assimiladas pelos agentes. Estas aprendizagens são consideradas como mais legítimas quando ocorrem precocemente no universo familiar. Ainda assim, a escola também é capaz de proporcionar aos que a frequentam uma relativa familiaridade com o mundo da arte, sendo seus resultados mais efetivos quando sua ação se dá sobre indivíduos dotados de conhecimentos prévios a respeito de seus conteúdos.

Entretanto, nem todas as famílias possuem capital cultural suficiente para transmitir aos seus filhos de modo a torná-los preparados para apreenderem a cultura erudita. Ao mesmo tempo, nem todas as instituições de ensino conseguem, diante de alunos desprovidos de um capital cultural original, fornecer elementos formativos suficientes para que os mesmos mantenham relações produtivas com a cultura. Este conjunto de circunstâncias representa justamente as condições formativas das alunas aqui investigadas. 
A fragilidade do capital cultural familiar destas estudantes é comprovada pelo baixo nível de instrução atingido por seus pais. Soma-se a isso, o fato das mesmas não tocarem instrumentos musicais e não dominarem uma língua estrangeira, saberes costumeiramente desenvolvidos fora do ambiente escolar. Além disso, a escola por elas frequentada e o modo como a formação escolar foi conduzida, dividindo a dedicação ao estudo com o trabalho, bem como as interrupções no processo formativo, dão indícios de que esta instituição teve pouca oportunidade no sentido de completar ou enriquecer a formação cultural prévia destas estudantes. Consequentemente, o baixo capital cultural incorporado limitou a capacidade de recepção das informações culturais, justamente pela ausência da posse dos códigos e instrumentos necessários à sua apropriação.

Longe de culpabilizar estas alunas pelo nível de formação cultural detido pelas mesmas, faz-se necessário compreender que o gosto por determinados produtos da cultura, sejam eles consagrados ou não, resultam de sua condição de origem e da posição ocupada por elas no interior do espaço social. Esta posição afeta suas disposições culturais e, ao mesmo tempo, suas percepções, representações e escolhas acerca do mundo no qual estão inseridas, tal como será discutido a seguir.

\subsection{O AMOR FATI, OU O AMOR AO DESTINO, E A ESCOLHA PROFISSIONAL}

Procurando conhecer o nível de identificação das alunas com o curso de Pedagogia, a pesquisa teve sua atenção dirigida à escolha profissional realizada por elas para o ingresso no ensino superior. A intenção era verificar se a frequência a esta graduação era de fato desejada, por meio da observância da eleição do curso como primeira opção de formação profissional. Além disso, as expectativas ocupacionais e de formação continuada também foram investigadas, tendo em vista perceber se o exercício do magistério primário pairava entre suas aspirações e se os estudos posteriores demonstravam o interesse de permanência na profissão com o aprofundamento de seus conhecimentos teóricos.

Indagadas a respeito do curso de Pedagogia ter sido a primeira opção de formação profissional, grande parte das alunas investigadas (16/20) responderam à pergunta positivamente. Ao mesmo tempo, praticamente a totalidade do grupo (19/20) contou com o apoio familiar frente à decisão tomada. A adesão destas alunas ao curso escolhido é novamente reafirmada quando as mesmas apresentam suas expectativas profissionais após a conclusão da 
graduação, visto que dezoito delas querem atuar como professoras na educação infantil ou no ensino fundamental, preferencialmente em instituições públicas.

Considerando o grupo de respondentes, somente duas alunas não manifestaram o desejo de exercer o magistério, apesar de terem apontado o curso de Pedagogia como sua primeira opção formativa. No caso da primeira, foi revelada a vontade de atuar na área de administração escolar, seja como coordenadora pedagógica ou diretora de escola, enquanto a segunda não expressou nenhuma expectativa profissional, talvez por já ter indicado em questão anterior sua ocupação como professora de educação infantil. No caso desta última, porém, houve a menção do propósito de cursar uma nova graduação em História, bem como frequentar um curso de especialização em educação. O desejo de continuidade dos estudos também foi declarado pela aluna com pretensão de atuar na área de gestão escolar. Nestes dois casos, apesar de não se fazer presente a intenção do exercício do magistério, a área educacional não foi totalmente rejeitada, destacando-se principalmente o projeto das duas alunas de frequentarem cursos de especialização.

A propósito do tema formação continuada, a perspectiva de aprofundamento dos conhecimentos por meio da frequência a cursos de especialização foi citada por catorze respondentes, dado que reforça a percepção da existência do interesse pela área e da vontade de permanecerem no ramo profissional escolhido, mesmo após a conclusão do curso. Apenas cinco alunas manifestaram disposição para cursar uma nova graduação. Em meio a estas últimas, duas mencionaram os cursos pretendidos, dentre os quais constam a formação em História e Geografia, sem que a modalidade dos mesmos - bacharelado ou licenciatura - fosse informada. Entre todas as interessadas pelo curso de novas graduações, a Pedagogia foi indicada como primeira opção de formação profissional, ao mesmo tempo que aludiram a intenção de atuar como docentes após o encerramento desta formação. Desse modo, o plano de frequentar uma nova graduação não permite que se afirme a ausência do interesse por parte das mesmas pelo curso de Pedagogia e pela profissão docente.

Para essas alunas, as experiências de estágio não foram compreendidas como vivências negativas ou desestimulantes, tal como muitos alunos de cursos de licenciatura relatam. Pelo contrário, de acordo com as declarações obtidas, além do estágio não ter alterado seus planos profissionais, o mesmo fez com que a vontade de atuar na área educacional se fizesse ainda mais presente, tal como ilustra o registro a seguir: "Criou ainda mais interesse em trabalhar com as crianças". Ao mesmo tempo, o estágio serviu para muitas formandas como uma oportunidade de reiterar a convicção de que fizeram a escolha certa em termos profissionais: 
"O estágio trouxe a certeza da minha escolha profissional”;

“Percebi que é isso mesmo que quero. Contribuir com a educação do nosso país.”;

“O estágio me deu a certeza de que realmente quero ser uma educadora”.

Vale ressaltar que a experiência do estágio foi interpretada de forma positiva por todas as alunas do grupo. Até mesmo as estudantes que indicaram o desejo de frequentar outra graduação após o encerramento do curso se referiram a sua prática de estágio com grande entusiasmo, sendo delas a autoria destes dois últimos depoimentos.

Questionadas a respeito das razões que as levaram a frequentar o curso de Pedagogia ${ }^{10}$, o conjunto de respostas oferecidas possibilitou a identificação de duas grandes motivações. $\mathrm{O}$ primeiro grupo de justificativas centrou-se nos relatos que declaravam uma manifesta identificação pessoal das alunas com o trabalho docente e com o público atendido nas escolas de educação infantil e ensino fundamental (11/20). Para elas a dedicação ao magistério consiste na realização de uma ambição há muito tempo aguardada:

"Eu sempre gostei da ideia de ser professora”;

“A realização de um sonho. Sempre quis ser pedagoga”.

Ao mesmo tempo o desempenho desta ocupação é significativamente valorizado:

“Acho uma dádiva ajudar a formar um ser humano. É uma profissão linda”.

Mesmo quando a afinidade pelo trabalho com crianças foi apresentada como justificativa principal da escolha profissional, outros argumentos complementares que expressavam o interesse pela profissão, pelo tema educacional e pelo curso eram simultaneamente manifestos, oferecendo um sentido mais fundamentado à decisão tomada:

"Por gostar de crianças e pela profissão";

“A paixão que eu tenho por crianças e pelo curso em si”;

"Gosto de lidar com pessoas, principalmente com crianças, sou paciente, me interesso pelas teorias que abordam a temática educacional”.

O segundo grupo de justificativas para a escolha do curso de Pedagogia reúne as explicações que destacam os interesses de ordem profissional (7/20). Parte das alunas trabalhava na área da educação antes do início do curso e a permanência delas na função que

\footnotetext{
${ }^{10}$ Somente duas alunas indicaram motivos outros que não foram passíveis de serem enquadrados na categorização realizada. Nestes casos as justificativas relacionaram-se com o desejo de transformar a sociedade e a influência de familiares que atuam na área.
} 
estavam desempenhando ou até mesmo a ascensão para a execução de outras atribuições, dependia da formação em Pedagogia: “Já trabalhava na área e precisava ser formada para continuar". A ampliação de oportunidades profissionais, vislumbrada com a conclusão do curso, também foi apontada diante da possibilidade de abrirem uma escola ou ainda obterem um emprego no âmbito do serviço público. Além disso, a busca pelo aperfeiçoamento profissional foi igualmente indicada como argumento para a frequência desta graduação: "Primeiramente porque já tenho o magistério. Desde cedo já havia exercido a profissão de professora, mas senti a necessidade de melhorar profissionalmente, pois o magistério ofereceu muita prática, porém pouca teoria”.

Considerando a pergunta “O que é ser professor?", as respostas oferecidas indicaram uma multiplicidade significativa de representações, entretanto a maior concentração de respostas identificou o professor ao trabalho pedagógico por ele desempenhado, junto aos alunos das séries iniciais (9/20). Neste caso, foram ressaltados os aspectos didáticos da ação docente envolvendo as dimensões do ensino, do conhecimento e da relação com os alunos: "Ser um Professor é mediar e levar o aluno a buscar o seu próprio conhecimento, compreendendo as dificuldades e o tempo de cada aluno". A representação de que o professor é aquele que realiza a mediação do conhecimento na sua relação com os estudantes foi frequentemente citada, sendo perceptível a rejeição da perspectiva que centraliza o professor no processo pedagógico. O aluno, quando não emerge como elemento principal, ocupa ao lado do professor o mesmo nível de importância: "É fazer uma viagem pelo saber de mãos dadas com o aluno". Além do professor ser identificado como um orientador da aprendizagem autônoma dos alunos, sem nunca perdê-los de vista, ele também foi reconhecido como responsável pela instrumentalização dos mesmos na aquisição da capacidade de leitura e escrita "Se dedicar ao máximo não só na questão de alfabetizar, mas também letrar o aluno”, residindo aí sua importância: "Tudo. Porque sem eles nós não aprendemos a enfrentar o mundo da escrita e da leitura".

O enaltecimento do trabalho docente e da própria figura do professor foi declarado por uma pequena parte das alunas (3/20) quando responderam à pergunta “O que é ser professor?". Dentre os retornos registrados nesse sentido surgiram declarações como as apresentadas a seguir:

“Uma pessoa sábia.”;

“Muito bom." 
e "Ser professor é ser uma pessoa com muita sorte."

Por outro lado, os discursos que se mostraram mais conscientes das dificuldades que envolvem a profissão (4/20) apresentaram o professor como alguém que se dedica a um trabalho que requer elevado investimento pessoal, dedicação e esforço, diante da ausência do reconhecimento salarial, social e das adversidades que envolvem o trabalho nas escolas. Assim, emergem nas manifestações das alunas a percepção de que, para ser professor, é preciso "gostar", tal como ilustra o relato a seguir: "Ensinar aquilo que aprendeu de forma que gostaria de ter aprendido. É saber que por mais que seu trabalho não seja valorizado, você faz isso porque gosta, porque tem o dom de ensinar. É ter noção de quanto importante e bonita a profissão é”. A visão sacerdotal do trabalho que transforma o exercício da profissão docente no cumprimento de uma missão é apresentada como justificativa para o desempenho de uma ocupação cercada por problemas e dificuldades: "É buscar constantemente formas de ensinar, de se fazer entender, de refletir sua prática. Ter amor ao próximo, acreditar no futuro, não desistir apesar das dificuldades encontradas seja na escola, com os alunos, no salário. É acreditar que você está plantando sementinhas que podem dar muito frutos a médio prazo". É possível observar nestas duas declarações que parte das respondentes reconhecem a importância do conhecimento profissional, resultado da aquisição de uma formação específica para a docência, entretanto, esse conhecimento não é compreendido como suficiente, já que valores missionários e vocacionais apresentam-se como necessários, uma vez que para elas ser professor está "Além da profissão".

Tomando os resultados acima apresentados, de modo geral, é possível constatar um significativo engajamento das alunas em relação ao curso de Pedagogia e ao trabalho docente. Este interesse pôde ser observado pelo elevado número de estudantes que escolheram o curso como primeira opção de formação profissional, sendo esta decisão consolidada pela prática do estágio. As respondentes também expressaram o interesse em exercer a profissão docente, além de pretenderem aperfeiçoar seus conhecimentos por meio de cursos de especialização na área. Paradoxalmente, quando essas alunas foram indagadas a respeito da profissão que desejavam para os seus filhos, as respostas registradas $(11 / 20)$ apontaram a preferência pelas profissões tradicionalmente mais valorizadas: Direito, Engenharia e Medicina (8/11), enquanto somente duas alunas manifestaram a intenção de seus filhos seguirem seus passos e atuarem como professores.

Cabe destacar que a escolha profissional não é aqui compreendida como resultado de uma decisão racionalizada com análise prévia, por parte daquele que decide, das compensações 
gerais que serão obtidas posteriormente, tal como sugerem os estudos no âmbito da economia do trabalho e da teoria da escolha racional (LEME, 2012; NOGUEIRA, 2004). Nestas perspectivas, familiares e alunos realizam uma avaliação consciente e planejada de suas aspirações formativas envolvendo a análise dos custos e benefícios contidos nesta decisão. Longe destas concepções, o conceito aqui empregado para compreender o processo de escolha do curso envolve a noção de habitus, tal como foi elaborada por Pierre Bourdieu.

O conceito de habitus, em Bourdieu (2003a), procura teorizar a ação dos agentes a partir do esforço de superação das contradições existentes entre as perspectivas objetivistas e subjetivistas do conhecimento. Enquanto a primeira toma as práticas como resultado de uma "reação mecânica" às regularidades que ordenam o espaço social, o subjetivismo concede aos sujeitos autonomia e consciência excessivas no desempenho de suas ações. Transpondo tal contradição, Bourdieu elabora o conceito de habitus explicando que as práticas sociais são estruturadas e apresentam, por conta disso, características típicas da posição social ocupada pelo agente. Ao mesmo tempo, tal estruturação resulta da remanência dos condicionamentos primários da situação social de origem, no interior dos sujeitos, os quais emergem sob a forma de disposições para a ação. O habitus é, portanto, história assimilada pela vivência de experiências que permitiram a incorporação de padrões sociais, os quais atuam como fontes geradoras de percepções e apreciações, orientadoras das práticas futuras. Essas práticas, ao seu turno, serão tão mais diferenciadas entre os sujeitos, quanto mais distantes os mesmos estiverem em suas posições ocupadas no interior da estrutura social. Como decorrência, as ações dos agentes passam a representar uma determinada classe, visto que seus atos reproduzem justamente os modos do seu grupo social de origem.

A compreensão a respeito da maneira como o habitus atua sobre os agentes sociais permite que a decisão por um determinado curso de formação profissional não seja admitida como resultado de uma escolha deliberada. Ao contrário, as escolhas resultam de uma condição de pensamento e ação que corresponde aos condicionamentos primários, os quais delimitam a “opção" profissional ao cumprimento daquilo que parece possível e viável, sem que haja por parte do indivíduo, uma avaliação consciente das suas chances de realização frente à decisão tomada. Esse modo de ação "inconsciente" resulta da posse de um habitus que projeta, a partir das experiências passadas de pessoas pertencentes ao mesmo grupo social, as probabilidades atuais de êxito: "Assim, o habitus representa a inércia do grupo, depositada em cada organismo sob a forma de esquemas de percepção, apreciação e ação que tendem, com mais firmeza do que todas as normas explícitas (...), a assegurar a conformidade das práticas para além das 
gerações" (BOURDIEU, 2013, p. 125). Pelo fato das práticas produzidas pelo habitus serem orientadas pelas condições de origem, as ações tomadas no momento presente serão guiadas por antecipações dos resultados prováveis, fundadas na experiência anterior, acerca de uma realidade imaginada, presumida, sendo este o princípio da causalidade do provável. Este movimento termina por gerar a impressão ilusória de que as decisões tomadas pelos agentes resultam da delimitação de metas racionalizadas, verdadeiras escolhas. Entretanto, Bourdieu justifica a adequação das práticas como o resultado da correspondência entre as condições objetivas atuais e o habitus constituinte do agente.

Relembrando a posição das respondentes aqui investigadas no interior do espaço social, considerando-se o volume do seu capital global, podemos compreender que a escolha profissional das mesmas foi cerceada por uma série de limites impostos às suas condições objetivas. O baixo capital cultural e econômico conduziram a determinação de um objetivo formativo mais próximo das suas condições de realização: a escolha de um curso de curta duração; em período parcial de dedicação; no interior de uma instituição de ensino que requereu baixos investimentos financeiros e uma modesta bagagem cultural para ser iniciado e, também, concluído. Para o perfil dessas alunas, um conjunto de profissões situam-se no campo do improvável. Cursos que exigem uma grande dedicação, impedindo o exercício de algum ofício enquanto o mesmo é frequentado e que requisitam uma razoável formação escolar prévia e elevados investimentos financeiros, estariam fora das possibilidades de realização destas estudantes.

A escolha do curso de Pedagogia, decisão entendida por uma parte significativa das respondentes como a manifestação de seu interesse e pendor pessoal, encobre para as mesmas o direcionamento profissional ao qual foram submetidas. O habitus destas alunas, marcado pelos condicionamentos primários referentes à sua origem de classe, afetou suas decisões e expectativas profissionais, engendrando práticas viáveis no interior dos limites de suas condições de vida. O "amor" à profissão, constantemente declarado ao longo da pesquisa, a certeza da escolha profissional realizada e o desejo manifesto pelo exercício da docência associado à ideia de realização pessoal, apesar das dificuldades que envolvem o trabalho docente, demonstram um modo de agir marcado pela aceitação virtuosa e serena do destino ocupacional que lhes coube cumprir, sendo este, porém, entendido pelas mesmas como a manifestação da sua própria vocação profissional. Esse destino, porém, não é o mesmo sonhado para seus filhos. 
A decisão pelo curso de Pedagogia e pelo exercício do magistério, resultante de uma escolha guiada pelo sentido de realidade, é o que fez com que estas alunas não tomassem o sonho da profíssão dos filhos para si próprias. As respostas obtidas frente ao questionamento “Que tipo de profissão você gostaria que seu filho tivesse?”, derivou do modo como a pergunta foi elaborada, criando a possibilidade de escolha por profissões, livre de qualquer tipo de restrição objetiva. Entretanto, a revelação do interesse de ascensão futura, a ser realizado por intermédio dos filhos, também foi algo conquistado por essas estudantes. Filhas de progenitores com baixa formação escolar, o ingresso no ensino superior e o acesso a uma profissão que escapa do trabalho de caráter manual, representou uma estratégia de ascensão social que as fez superar em muito a condição de vida experimentada pelos próprios pais. Daí decorre a clara concordância da família em relação à decisão profissional tomada.

O interesse manifesto pelas respondentes em trabalhar como professoras da rede pública de ensino corresponde, por sua vez, a uma estratégia de reprodução que objetiva melhorar ou, ao menos, manter suas posições no interior da estrutura social. Para elas, o trabalho em instituições privadas não traria a segurança financeira que a condição de funcionário público é capaz de proporcionar. Preocupação justificada pela ausência da posse de um capital econômico capaz de resistir às incertezas da manutenção do emprego, ao mesmo tempo que as experiências vivenciadas pelas mesmas em seus trabalhos como docentes ou estagiárias, em pequenas instituições particulares de ensino, demonstraram o baixo retorno financeiro passível de ser obtido ${ }^{11}$. Nestas condições, a docência em escolas públicas surge como uma opção de encaminhamento profissional bastante desejável.

Retomando o segundo grupo de razões para a escolha do curso de Pedagogia, os interesses profissionais de parte destas formandas ilustram mais uma vez a ação dos condicionamentos primários referentes à sua origem de classe. A decisão, fruto de um gosto da necessidade, manifesta o modo como as condições materiais de existência afetam fortemente as "escolhas" de vida nas classes sociais menos privilegiadas. Neste caso, o gosto pessoal pela profissão, está ao mesmo tempo associado à necessária conservação do trabalho e a possibilidade de melhoria das condições atuais de vida. Este movimento, compreendido como uma estratégia de reprodução, é renovado pelo interesse das alunas em investir na continuidade de seus estudos por meio da frequência a cursos de especialização em educação, tentativa de

\footnotetext{
${ }^{11}$ Tal como foi apresentado no primeiro subitem deste capítulo, o salário pago às respondentes que já trabalhavam como professoras, antes de iniciarem o curso, pouco se diferencia daquele atribuído às alunas que atuam como estagiárias.
} 
valorizar a formação universitária conquistada e evitar uma possível desclassificação, tão comum aos agentes sociais que partilham desta mesma posição no interior da estrutura social.

O capítulo aqui apresentado se dedicou ao estudo do perfil socioeconômico e cultural dos respondentes que cursavam o último ano da sua graduação em Pedagogia na Universidade Bandeirante de São Paulo - Anhanguera. Após o delineamento da origem social dos formandos, foi realizado um movimento de associação da mesma com suas práticas culturais e com os modos como se deu a escolha profissional. As expectativas ocupacionais dos respondentes, bem com seus planos formativos a serem implementados após a conclusão do curso, foram identificados, da mesma maneira que suas representações acerca da profissão docente. Todo esse procedimento de construção do capítulo permitiu identificar a origem popular desses estudantes, cujas práticas culturais - caracterizadas pela massificação do gosto - revelaram mais uma vez a posição pouco privilegiada desses agentes na estrutura social. Por conta do baixo volume de capitais detidos, a escolha profissional foi circunscrita por condições objetivas que delimitaram não só o curso a ser frequentado, como também a universidade onde a graduação poderia ser cursada. Esse mesmo modo de estudo foi implementado na investigação dos respondentes da UNIFESP, cujos dados serão apresentados no capítulo a seguir. 


\section{Cursar Pedagogia na UNIFESP de Guarulhos: as expectativas DE GANHOS SIMBÓLICOS E CONCRETOS ENVOLVIDAS NESTA DECISÃO}

\subsection{RELAÇÕES ENTRE O TODO E A PARTE - O CAMPUS DE GUARULHOS E O CURSO DE PEDAGOGIA DA UNIFESP}

O estudo do perfil dos formandos da UNIFESP envolvidos nesta investigação ${ }^{1}$ identificou um conjunto predominantemente composto por mulheres, solteiras, sem filhos, enquanto a faixa etária de destaque é aquela situada entre os vinte e vinte e cinco anos de idade. No quesito cor de pele, mesmo com o maior número de brancos, a presença das demais categorias raciais revela a existência de uma certa diversidade em meio a estes alunos. Tal aspecto pode, em parte, ser relacionado ao fato da instituição ter reservado em seu processo seletivo $10 \%$ das vagas de ingresso, em cada um de seus cursos, para candidatos autodeclarados pretos, pardos ou indígenas. Essas vagas, vinculadas ao sistema de cotas, seriam destinadas somente aos candidatos que tivessem cursado todo o ensino médio em escolas públicas. No caso específico dos cursistas de Pedagogia incluídos neste estudo, sete alunos estão enquadrados neste perfil: são alunos negros, egressos de escolas públicas e que afirmaram terem concorrido às vagas vinculadas ao sistema de cotas raciais oferecidas no vestibular. Porém, o número de negros e indígenas presentes no grupo (24/56) é superior ao dos beneficiados pelo sistema de cotas (7/56), sendo esta uma peculiaridade do grupo investigado. Os dados estão apresentados na Tabela 3.1.

\footnotetext{
${ }^{1} \mathrm{O}$ número inicial de respondentes obtidos na UNIFESP foi de 56 alunos.
} 
Tabela 3.1 - Distribuição dos respondentes da UNIFESP segundo as variáveis sexo, idade, raça, estado civil e número de filhos.

\begin{tabular}{|c|c|c|}
\hline Variáveis & Categorias & $\mathrm{n}$ \\
\hline \multirow[t]{2}{*}{ Sexo } & Feminino & 46 \\
\hline & Masculino & 10 \\
\hline Total & & 56 \\
\hline \multirow[t]{3}{*}{ Faixa etária } & 20 a 25 & 34 \\
\hline & 26 a 30 & 7 \\
\hline & 31 ou mais & 15 \\
\hline Total & & 56 \\
\hline \multirow[t]{5}{*}{ Raça } & Branco & 31 \\
\hline & Pardo & 18 \\
\hline & Preto & 5 \\
\hline & Amarelo & 1 \\
\hline & Indígena & 1 \\
\hline Total & & 56 \\
\hline \multirow[t]{3}{*}{ Estado conjugal } & Casado & 15 \\
\hline & Solteiro & 39 \\
\hline & Separado & 2 \\
\hline Total & & 56 \\
\hline \multirow[t]{2}{*}{ Filhos } & Sim & 13 \\
\hline & Não & 43 \\
\hline Total & & 56 \\
\hline
\end{tabular}

Em relatório elaborado pela Pró-reitoria de Assuntos Estudantis da UNIFESP respeito do perfil socioeconômico e cultural dos alunos ingressantes do ano $2011^{2}$, foi identificada a predominância dos alunos brancos em todos os campi da instituição (Tabela 3.2). O campus de Guarulhos, porém, se distinguiu dos demais por possuir a maior parcela de alunos negros, estando os mesmos presentes de modo acentuado no curso de Pedagogia noturno. Convém mencionar que em outros campi alguns cursos se destacaram por apresentarem uma quantidade mais elevada de pretos ou pardos. Na Baixada Santista, por exemplo, o curso de bacharelado em serviço social vespertino reuniu o maior número de pardos do campus, tal como ocorreu em Diadema no curso de licenciatura em ciências noturno. A partir dessas informações, é possível notar que os alunos negros ingressam na UNIFESP principalmente nos cursos de ciências humanas e licenciaturas, constatação que vai ao encontro do perfil racial identificado entre os respondentes participantes desta pesquisa.

\footnotetext{
${ }^{2} \mathrm{O}$ relatório em questão consiste em um estudo inicial do perfil dos ingressantes da UNIFESP, realizado com base em dados dos ingressantes de 2011. Os autores destacaram as medidas do governo federal voltadas para a expansão do ensino superior e os impactos sofridos pela universidade, que compreendeu a necessidade de conhecer quem são seus novos alunos, tendo em vista a promoção de ações institucionais adequadas ao seu público. Os itens avaliados pelo relatório abrangeram aspectos como faixa etária; cor da pele; situação conjugal; localização da moradia; situação de trabalho; renda; escolaridade dos pais e proveniência escolar dos estudantes.
} 
Tabela 3.2 - Distribuição por campus da cor da pele dos ingressantes da UNIFESP (2011).

\begin{tabular}{llllllll}
\hline Variável & Categorias & Baixada & Diadema & Guarulhos & Osasco & São J. Campos & São Paulo \\
\hline Cor da pele & Amarela & 5,36 & 9,55 & 3,63 & 7,99 & 6,52 & 12,77 \\
& Branca & 72,5 & 69,01 & 62,7 & 72,92 & 76,09 & 69,78 \\
& Indígena & 0 & 0,39 & 0,17 & 0 & 0 & 0 \\
& Parda & 20,35 & 17,54 & 26,4 & 16,31 & 16,3 & 15,26 \\
& Preta & 1,79 & 3,51 & 7,1 & 2,78 & 1,09 & 2,19 \\
\hline
\end{tabular}

Fonte: Pró-reitoria de Assuntos Estudantis - UNIFESP

Tabela 3.3 - Cor da pele ingressantes Guarulhos x curso (2011).

\begin{tabular}{lllllll}
\hline Variável & Cursos & Amarela & Branca & Indígena & Parda & Preta \\
\hline Cor da pele Guarulhos & Filosofia vespertino & 5,26 & 54,39 & 0 & 29,82 & 10,53 \\
& História vespertino & 2,17 & 82,61 & 0 & 10,87 & 4,35 \\
& História da Arte noturno & 4,76 & 54,14 & 0 & 35,71 & 2,38 \\
& Letras (Port./Ing.) vespertino & 8,7 & 82,61 & 0 & 8,7 & 0 \\
& Letras (Port./Fr.) vespertino & 4,55 & 59,09 & 0 & 13,64 & 22,73 \\
& Letras (Port./Esp.) noturno & 0 & 60 & 0 & 20 & 20 \\
& Letras (Port.) vespertino & 4,76 & 61,9 & 0 & 33,33 & 0 \\
& Pedagogia vespertino & 6 & 62 & 2 & 24 & 6 \\
& Pedagogia noturno & 5,66 & 43,4 & 0 & 39,62 & 11,32 \\
\hline
\end{tabular}

Fonte: Pró-reitoria de Assuntos Estudantis - UNIFESP

Retomando os dados dos respondentes do último ano do curso de Pedagogia a respeito de seu percurso formativo (Tabela 3.4), pode-se afirmar que parte significativa concluiu sua formação em estabelecimentos públicos, enquanto o ensino médio foi cursado predominantemente no período diurno e na modalidade regular, em escolas situadas no Estado de São Paulo. Quanto ao trabalho durante o ensino médio, o mesmo se deu para pouco menos da metade do grupo de respondentes (26/55). Para eles, a jornada integral de trabalho foi a mais comum, principalmente entre os alunos que cursaram o ensino médio no período noturno (11/16). As justificativas apresentadas para o trabalho durante o ensino médio abrangeram a necessidade de prescindir da família para a manutenção dos custos pessoais e colaborar no pagamento das despesas domésticas. 
Tabela 3.4 - Distribuição dos respondentes da UNIFESP segundo a trajetória escolar e trabalho no ensino médio.

\begin{tabular}{|c|c|c|}
\hline Variáveis & Categorias & $\mathbf{n}$ \\
\hline \multirow{3}{*}{ Ensino Fundamental } & Privado & 17 \\
\hline & Público & 30 \\
\hline & Público/Privado & 8 \\
\hline Total & & $55^{3}$ \\
\hline \multirow[t]{3}{*}{ Ensino Médio } & Privado & 18 \\
\hline & Público & 34 \\
\hline & Público/Privado & 3 \\
\hline Total & & 55 \\
\hline \multirow[t]{4}{*}{ Local de conclusão do Ensino Médio } & $\mathrm{SP}$ & 52 \\
\hline & AM & 1 \\
\hline & $\mathrm{BA}$ & 1 \\
\hline & MG & 1 \\
\hline Total & & 55 \\
\hline \multirow[t]{4}{*}{ Modalidade do Ensino Médio } & Regular & 43 \\
\hline & Normal/magistério & 2 \\
\hline & EJA & 3 \\
\hline & Técnico profissionalizante & 7 \\
\hline Total & & 55 \\
\hline \multirow[t]{2}{*}{ Turno do Ensino Médio } & Diurno & 39 \\
\hline & Noturno & 16 \\
\hline Total & & 55 \\
\hline \multirow[t]{2}{*}{ Trabalho no Ensino Médio } & Sim & 26 \\
\hline & Não & 29 \\
\hline Total & & 55 \\
\hline \multirow[t]{3}{*}{ Jornada de trabalho no Ensino Médio } & Até $20 \mathrm{~h} / \mathrm{s}$ & 7 \\
\hline & De 21 a $30 \mathrm{~h} / \mathrm{s}$ & 7 \\
\hline & De 31 a 40 h/s & 12 \\
\hline Total & & 26 \\
\hline
\end{tabular}

Continuando as observações a respeito da trajetória formativa destes respondentes (Tabela 3.5), foi possível notar que vinte e quatro deles já haviam começado outro curso superior, antes de ingressarem na graduação em Pedagogia. Destes, somente nove alunos concluíram a formação iniciada nas áreas de Ciências Biológicas; licenciatura em História (2 alunos) e em Letras; Jornalismo; Tecnólogo em Gestão Ambiental; Relações Públicas; Teologia e Processamento de dados ${ }^{4}$.

Tabela 3.5 - Distribuição dos respondentes da UNIFESP segundo o início de curso de graduação anterior à pedagogia.

\begin{tabular}{lll}
\hline Variáveis & Categorias & $\mathbf{n}$ \\
\hline Iniciou outra graduação & Sim & 24 \\
& Não & 31 \\
Total & & 55 \\
& & \\
Concluiu o curso iniciado & Sim & 9 \\
& Não & 15 \\
Total & & 24 \\
\hline
\end{tabular}

\footnotetext{
${ }^{3} \mathrm{O}$ número de respondentes a partir desta questão caiu de 56 para 55, após um dos respondentes abandonar o questionário antes da finalização do mesmo.

${ }^{4}$ A discussão a respeito do interesse destes alunos em cursar a segunda graduação em pedagogia será feita no terceiro item deste capítulo.
} 
No caso dos alunos que tomaram o curso de pedagogia como a primeira formação superior (31 estudantes), foi possível perceber uma diferença não muito significativa entre os que decidiram (18/31) ou não (13/31) pela formação complementar em cursinhos preparatórios (Tabela 3.6). Destes respondentes, mais da metade ingressou na universidade até doze meses após o encerramento do ensino médio (16/31), dentre os quais nove alunos frequentaram cursinhos por até um ano. Entre os estudantes que aguardaram mais de dois anos para o início do curso (15/31), verificou-se novamente pouca diferença entre os que frequentaram cursinho (9) e os que ingressaram sem recorrer aos mesmos (6). Ao mesmo tempo, os estudantes que experimentaram os maiores intervalos entre a finalização da educação básica e o ingresso no ensino superior foram justamente aqueles que frequentaram o ensino médio noturno e que trabalharam durante jornadas integrais, tendo em vista o sustento próprio e o familiar. Por outro lado, desconsiderando o intervalo entre a finalização do ensino médio e o ingresso no ensino superior, de todos os alunos que não frequentaram cursos preparatórios (13 alunos), somente quatro finalizaram o ensino médio em escolas particulares, contra nove alunos oriundos de escolas públicas.

Tabela 3.6 - Distribuição dos respondentes da UNIFESP não graduados anteriormente, em relação ao tempo de permanência no cursinho e intervalo entre a finalização do ensino médio e ingresso no curso de pedagogia.

\begin{tabular}{lccccccc}
\hline $\begin{array}{l}\text { Tempo de ingresso no curso de } \\
\text { pedagogia como primeira } \\
\text { graduação, após o ensino médio }\end{array}$ & \multicolumn{7}{c}{ Permanência cursinho } \\
\hline & Não & Até 1 & 1 sem a & 1 a 1,5 & 1,5 a 2 & Acima de \\
& frequentou & sem & 1 ano & ano & anos & 2 anos & Total \\
Menos de um ano & 7 & 3 & 2 & 0 & 0 & 0 & 12 \\
Um ano & 0 & 0 & 4 & 0 & 0 & 0 & 4 \\
Entre 2 e 3 anos & 1 & 0 & 2 & 1 & 1 & 1 & 6 \\
Cinco anos ou mais & 5 & 1 & 1 & 1 & 0 & 1 & 9 \\
Total & 13 & 4 & 9 & 2 & 1 & 2 & 31 \\
\hline
\end{tabular}

As informações acima mostram que, entre os respondentes, o ingresso no curso de Pedagogia da UNIFESP não se constituiu como privilégio de alunos formados em escolas particulares, havendo uma presença notória de ex-alunos das escolas públicas, mesmo quando estes prescindiram de preparo complementar nos cursinhos ${ }^{5}$. Este preparo, por sua vez, não se mostrou como elemento decisivo para o ingresso no curso, havendo equilíbrio entre o número de respondentes que estudaram ou não nestes estabelecimentos, mesmo entre aqueles que estiveram mais de dois anos afastados dos bancos escolares. Ainda a respeito da formação complementar em cursinhos, o confronto entre o número dos respondentes não graduados anteriormente e a decisão pelo curso de Pedagogia como primeira ou segunda opção formativa

\footnotetext{
${ }^{5}$ Dentre os 55 respondentes, 18 cursaram o ensino médio em escolas particulares, enquanto 34 frequentaram escolas públicas. Por fim, três alunos cursaram o ensino médio parcialmente em instituições públicas e particulares.
} 
indica pouca diferença entre os que tinham essa formação profissional como prioritária (17/30) e a frequência ou não aos cursinhos. Entretanto, a procura por esses estabelecimentos foi ligeiramente superior quando a Pedagogia não se constituiu como a primeira opção do candidato $^{6}$, tal como ilustra a Tabela 3.7.

Tabela 3.7 - Distribuição dos respondentes da UNIFESP não graduados anteriormente, quanto à frequência a cursinhos e a escolha do curso de pedagogia como primeira ou segunda opção formativa.

\begin{tabular}{lll}
\hline Variáveis & Categorias & $\mathbf{n}$ \\
\hline Pedagogia primeira opção & Sim & 17 \\
& Não & 13 \\
Total & & 30 \\
& & \\
Cursinho entre os que tinham a pedagogia primeira opção & Sim & 9 \\
Total & Não & 8 \\
& & 17 \\
Cursinho entre os que tinham a pedagogia como segunda opção & Sim & 9 \\
Total & Não & 4 \\
\hline
\end{tabular}

O relatório elaborado pela Pró-reitoria de Assuntos Estudantis da UNIFESP não investigou a frequência a cursinhos entre os ingressantes do ano de 2011, entretanto, nota-se a partir de seus dados que os cursos da área de saúde e ciências exatas aprovaram majoritariamente candidatos formados em instituições particulares. Contrariamente, o campus de Guarulhos, assim como o curso de licenciatura em Ciências (Diadema) e bacharelado em Serviço Social (Baixada Santista), terminaram por abranger, de forma mais representativa, ingressantes oriundos das escolas públicas. A Tabela 3.8 apresenta os dados.

Tabela 3.8 - Origem escolar dos ingressantes da UNIFESP por campus (2011).

\begin{tabular}{llllllll}
\hline Variável & Categorias & Baixada & Diadema & Guarulhos & Osasco & São J. Campos & São Paulo \\
\hline \multirow{2}{*}{ Origem escolar } & Escola pública & 35 & 35,48 & 65,84 & 28,47 & 30,98 & 25,23 \\
& Escola particular & 65 & 64,33 & 33,99 & 71,53 & 69,02 & 74,77 \\
\hline
\end{tabular}

Fonte: Pró-reitoria de Assuntos Estudantis - UNIFESP

Essa especificidade em torno da origem formativa dos alunos aprovados nos cursos de licenciatura em Ciências (Diadema) e bacharelado em Serviço Social (Baixada Santista) pode ser explicada pelos mesmos possuírem a menor relação candidato/vaga e nota de corte de seus campus $^{7}$, caracterizando-se, portanto, como cursos menos seletivos. No caso de Guarulhos, é possível associar o maior volume de alunos egressos das escolas públicas entre seus aprovados,

\footnotetext{
${ }^{6}$ Os cursos inicialmente pretendidos por estes candidatos foram arquitetura, administração de empresas, psicologia, direito (2), letras (2) e gastronomia.

${ }^{7}$ As notas de corte utilizadas no sistema unificado de seleção do ano de 2011 foram consultas no próprio site da UNIFESP: < http://www.unifesp.br/reitoria/vestibular/vestibulares-anteriores>. Acesso em: 11 abr. 2015.
} 
ao fato dos cursos de licenciatura tradicionalmente possuírem notas de corte mais baixas nas universidades públicas. Esta afirmação, porém, é parcialmente verdadeira em meio a alguns cursos oferecidos neste campus. A observação das notas de corte implementadas no Sistema de Seleção Unificada ${ }^{8}$ de 2011 do campus de Guarulhos indicou a existência de cursos, cujos estudantes teriam a possibilidade de ingressar em outras carreiras, então ocupadas prioritariamente por estudantes egressos de instituições privadas. Por exemplo, os alunos dos cursos de licenciatura e bacharelado em História e Ciências Sociais poderiam ser aprovados nos cursos de Ciências Contábeis (Osasco); Ciência e Tecnologia (São José dos Campos), Matemática Computacional (São José dos Campos) e Tecnologia em Informática e Saúde (São Paulo). Entretanto, os estudantes dos cursos de Pedagogia e Filosofia vespertino, cujos cursos apresentam notas de corte mais baixas, não disporiam das mesmas possibilidades ${ }^{9}$.

Na Tabela 3.9 são apresentadas as notas de corte do campus de Guarulhos implementadas no Sistema de Seleção Unificada do ano de 2011. A partir desses dados, é possível identificar que a menor nota de corte do campus foi a utilizada para selecionar os aprovados do curso de Pedagogia vespertino e, confirmando os dados do levantamento realizado nesta investigação, mais uma vez o perfil dos aprovados é marcado pela formação predominante nas instituições públicas de ensino.

Tabela 3.9 - Nota de corte dos cursos do campus de Guarulhos (SISU) vestibular 2011 x origem escolar dos alunos aprovados.

\begin{tabular}{lllll}
\hline Curso & Turno & Nota de corte & Escola pública & Escola particular \\
\hline Pedagogia (licenciatura) & Vespertino & 673.97 & 60 & 40 \\
Filosofia (bacharelado/licenciatura) & Vespertino & 676.25 & 66,67 & 31,58 \\
Pedagogia (licenciatura) & Noturno & 678.16 & 81,13 & 18,87 \\
Filosofia (bacharelado/licenciatura) & Noturno & 682.22 & 74,47 & 25,53 \\
História (bacharelado/licenciatura) & Noturno & 703.19 & 57,45 & 42,55 \\
Ciências sociais (bacharelado/licenciatura) & Noturno & 708.35 & 81,82 & 18,18 \\
Ciências sociais (bacharelado/licenciatura) & Vespertino & 708.84 & 62 & 38 \\
História (bacharelado/licenciatura) & Vespertino & 709.36 & 52,17 & 47,83 \\
História da arte (bacharelado) & Noturno & 714.51 & 54,76 & 45,24 \\
\hline
\end{tabular}

Fonte: Pró-reitoria de Assuntos Estudantis - UNIFESP

\footnotetext{
${ }^{8}$ A seleção dos candidatos da UNIFESP ocorre a partir de dois sistemas: o sistema de seleção misto e o sistema de seleção unificada. Nessas duas modalidades a realização do Exame Nacional do Ensino Médio se constituiu como etapa obrigatória, variando apenas a forma de aproveitamento das notas obtidas. No caso do sistema misto, além do ENEM, alguns cursos aplicam uma prova complementar, assim a nota final resulta da composição do aproveitamento do aluno nos dois exames. No caso do sistema unificado, apenas a nota do ENEM é utilizada como meio de ingresso nos cursos, sendo o procedimento de seleção administrado pelo Instituto Nacional de Estudos e Pesquisas Educacionais Anísio Teixeira (INEP).

${ }^{9}$ Os alunos de Pedagogia vespertino só teriam chances de aprovação nos cursos de licenciatura plena em Ciências (vespertino e noturno) e bacharelado em Serviço Social (vespertino e noturno).
} 
Quanto ao nível de escolaridade familiar dos formandos de Pedagogia envolvidos nesta investigação, é possível verificar entre os pais um número levemente superior dos que possuem até o ensino fundamental, em relação aos que concluíram o ensino médio (Tabela 3.10). Este último nível de formação, por sua vez, foi o mais comum entre as mães, as quais se destacaram pelo desempenho de ocupações que envolviam o trabalho manual realizado principalmente no ambiente doméstico. Nas situações em que estas trabalharam fora de casa, as atividades mais comumente desenvolvidas foram as de costureira, doméstica e operária. Do mesmo modo, o trabalho manual foi o mais exercido pelos pais dos estudantes, cujas atividades mencionadas de modo recorrente foram mecânico, motorista, pedreiro e operário.

\section{Tabela 3.10 - Distribuição dos respondentes da UNIFESP segundo o nível de instrução paterno e materno e ocupação desenvolvida pelos mesmos.}

\begin{tabular}{|c|c|c|}
\hline Variáveis & Categorias & $\mathrm{n}$ \\
\hline Instrução pai & $\begin{array}{l}\text { Até Ensino Fundamental } \\
\text { Ensino Médio } \\
\text { Superior ou Pós-graduação } \\
\text { Não sei }\end{array}$ & $\begin{array}{l}22 \\
18 \\
12 \\
3 \\
55\end{array}$ \\
\hline Instrução mãe & $\begin{array}{l}\text { Até Ensino Fundamental } \\
\text { Ensino Médio } \\
\text { Superior ou Pós-graduação } \\
\text { Não frequentou escola }\end{array}$ & $\begin{array}{l}17 \\
26 \\
11 \\
1 \\
55\end{array}$ \\
\hline Ocupação pai & $\begin{array}{l}\text { Profissional liberal ou atividade profissional com exigência } \\
\text { formativa elevada. } \\
\text { Serviços administrativos, comércio, serviços técnicos e demais } \\
\text { ocupações que exigem formação escolar mediana. } \\
\text { Trabalho manual, produção de bens e serviços industriais e } \\
\text { atividades profissionais que exigem baixa exigência formativa. } \\
\text { Outros }^{10}\end{array}$ & $\begin{array}{l}9 \\
55\end{array}$ \\
\hline Ocupação mãe & $\begin{array}{l}\text { Profissional liberal ou atividade profissional com exigência } \\
\text { formativa elevada. } \\
\text { Serviços administrativos, comércio, serviços técnicos e demais } \\
\text { ocupações que exigem formação escolar mediana. } \\
\text { Trabalho manual, produção de bens e serviços industriais e } \\
\text { atividades profissionais que exigem baixa exigência formativa. } \\
\text { Outros }\end{array}$ & $\begin{array}{l}13 \\
26 \\
5 \\
55\end{array}$ \\
\hline
\end{tabular}

Tomando mais uma vez os dados do relatório da UNIFESP a respeito do nível de formação familiar dos ingressantes de 2011 (Tabela 3.11), observa-se que o campus de Guarulhos se destaca pelos pais possuírem de modo mais frequente o menor nível de escolaridade. Contrariamente, os campi de São Paulo e Osasco chamam a atenção por possuírem mais da metade dos pais com formação universitária. Uma forma de explicar essas diferenças se relaciona com as especificidades destas duas unidades da UNIFESP.

${ }^{10} \mathrm{O}$ item "Outros" foi aqui utilizado para designar os registros imprecisos realizados pelos respondentes, que impediram a clara identificação da ocupação desempenhada. 
O campus de São Paulo oferece cursos nas áreas de Ciências Biológicas (modalidade Medicina); Enfermagem; Fonoaudiologia; Medicina; Tecnologia em Informática em Saúde; TECNOLOGIA em Radiologia e Tecnologia Oftálmica. Osasco, por sua vez, disponibiliza cursos nas áreas de Administração; Ciências Atuariais; Ciências Contábeis; Ciências Econômicas e Relações Internacionais. De modo geral, nestes dois campi os cursos são mais disputados no processo seletivo, apresentando notas de corte elevadas, além do fato de parte dos mesmos ser oferecido na modalidade integral ${ }^{11}$. Estas duas características terminam por exigir competências formativas e condições econômicas diferenciadas por parte dos estudantes, distinguindo-os dos demais em relação à sua condição social de origem.

Tabela 3.11 - Escolaridade dos pais dos ingressantes da UNIFESP por campus (2011).

\begin{tabular}{llllllll}
\hline Variável & Categorias & Baixada & Diadema & Guarulhos & Osasco & São J. Campos & São Paulo \\
\hline Escolaridade pai & Até Ens. Fund. & 24,29 & 22,21 & 44,22 & 21,18 & 25,53 & 17,76 \\
& Até Ens. Médio & 35,71 & 38,21 & 28,88 & 25 & 40,22 & 27,72 \\
& Superior & 36,06 & 35,85 & 20,8 & 51,38 & 30,97 & 52,96 \\
& Não sei & 3,94 & 3,73 & 6,1 & 2,44 & 3,28 & 1,56 \\
& & & & & & & \\
Escolaridade mãe & Até Ens. Fund. & 22,87 & 24,37 & 39,77 & 17,7 & 24,99 & 14,64 \\
& Até Ens. Médio & 33,93 & 33,93 & 34 & 31,25 & 35,33 & 33,65 \\
& Superior & 42,86 & 40,74 & 25,25 & 50,7 & 39,68 & 51,4 \\
& Não sei & 0,34 & 0,96 & 0,98 & 0,35 & 0 & 0,31 \\
\hline
\end{tabular}

Fonte: Pró-reitoria de Assuntos Estudantis - UNIFESP

Retornando aos respondentes do curso de Pedagogia em seus aspectos profissionais, pode-se afirmar que o trabalho, no último ano do curso, foi menos comum no período diurno, uma vez que entre os dezenove alunos que não estavam trabalhando no momento da pesquisa, dezesseis pertenciam a esse turno, composto por um total de trinta estudantes. Por outro lado, o desenvolvimento de atividades profissionais foi prática usual entre os alunos do período noturno (22/25), com destaque para o regime integral de dedicação. Entre os alunos trabalhadores, de ambos os turnos, notou-se um movimento de iniciação à profissão, visto que grande parte já estava inserida na área educativa, atuando principalmente como estagiários. Merece atenção os locais escolhidos por estes estudantes para a realização do estágio, destacando-se o caráter público dos mesmos, não só das escolas como também dos demais espaços, tais como o Centro de Referência da Assistência Social (CRAS); Diretoria de Ensino; Arquivo Público do Estado de São Paulo, além de atividades desenvolvidas dentro da própria UNIFESP. As escolas particulares foram citadas como local de estágio por apenas quatro

${ }^{11}$ Em São Paulo os cursos que exigem dedicação integral são: Ciências Biológicas (modalidade Medicina); Enfermagem; Fonoaudiologia e Medicina. Em Osasco todos os cursos oferecidos contam com os turnos integral e noturno. 
alunos, enquanto três deles atuaram em instituições elitizadas como o Colégio Dante Alighieri e a escola Recanto Infantil do Club Athletico Paulistano.

Outro grupo ocupacional de destaque entre os respondentes abrange os alunos que já atuavam como professores, mesmo antes da conclusão do curso (11/36). Dois deles eram docentes de língua inglesa e trabalhavam ministrando aulas particulares. Os demais dividiramse entre os que atuavam em escolas particulares (4/11) e os que lecionavam em instituições públicas de ensino (5/11). Entre estes profissionais a faixa salarial variou de um a cinco salários mínimos (Tabela 3.12). Entretanto, os funcionários públicos representam os que detinham um retorno salarial mais estável e elevado, quando comparados ao restante do grupo de professores, estando a renda dos mesmos situada entre os limites de três a cinco salários mínimos.

Tabela 3.12 - Distribuição dos respondentes UNIFESP quanto à atividade ocupacional, rendimentos e regime de trabalho durante a graduação.

\begin{tabular}{|c|c|c|}
\hline Variáveis & Categorias & $n$ \\
\hline Trabalho no último ano do curso & $\begin{array}{l}\text { Sim } \\
\text { Não }\end{array}$ & $\begin{array}{l}36 \\
19\end{array}$ \\
\hline $\begin{array}{l}\text { Trabalho no último ano do curso } \\
\text { Total }\end{array}$ & $\begin{array}{l}\text { Diurno } \\
\text { Noturno }\end{array}$ & $\begin{array}{l}14 \\
22 \\
36\end{array}$ \\
\hline Ocupação & $\begin{array}{l}\text { Atividades não educacionais } \\
\text { Docência } \\
\text { Estágio } \\
\text { Iniciação científica } \\
\text { Trabalho administrativo em escola }\end{array}$ & $\begin{array}{l}7 \\
11 \\
14 \\
1 \\
3 \\
36\end{array}$ \\
\hline Rendimentos & $\begin{array}{l}\text { Até } 1 \text { s.m. } \\
\text { Entre } 1 \text { e } 2 \text { s.m. } \\
\text { Entre } 2 \text { e } 3 \text { s.m. } \\
\text { Entre } 3 \text { e } 5 \text { s.m. } \\
\text { Entre } 7 \text { a } 10 \text { s.m. }\end{array}$ & $\begin{array}{l}9 \\
13 \\
7 \\
6 \\
1 \\
36\end{array}$ \\
\hline Rendimentos professoras & $\begin{array}{l}\text { Entre } 1 \text { e } 2 \text { s.m. } \\
\text { Entre } 2 \text { e } 3 \text { s.m. } \\
\text { Entre } 3 \text { e } 5 \text { s.m. }\end{array}$ & $\begin{array}{l}5 \\
2 \\
4 \\
11\end{array}$ \\
\hline $\begin{array}{l}\text { Rendimentos estagiárias } \\
\text { Total }\end{array}$ & $\begin{array}{l}\text { Até } 1 \text { s.m. } \\
\text { Entre } 1 \text { e } 2 \text { s.m. }\end{array}$ & $\begin{array}{l}8 \\
6 \\
14\end{array}$ \\
\hline $\begin{array}{l}\text { Regime de trabalho } \\
\text { Total }\end{array}$ & $\begin{array}{l}\text { Parcial } \\
\text { Integral }\end{array}$ & $\begin{array}{l}9 \\
27 \\
36\end{array}$ \\
\hline
\end{tabular}

Os dados envolvendo a condição econômica individual e familiar dos respondentes evidenciam que as faixas de renda mais comuns estão situadas entre menos de um a até dois salários mínimos per capita mensais (Tabela 3.13). O número elevado de alunos enquadrados neste mesmo nível de renda (44/55) indica ser esta uma característica comum ao grupo, sem variações, mesmo levando em consideração a divisão entre os turnos (Tabela 3.14). 
Tabela 3.13 - Distribuição dos respondentes UNIFESP quanto à renda familiar mensal e renda familiar mensal per capita.

\begin{tabular}{lll}
\hline Variáveis & Categorias & $\mathbf{n}$ \\
\hline Renda familiar mensal & 1 até 2 s.m. & 5 \\
& 2 até 3 s.m. & 13 \\
3 até 5 s.m. & 12 \\
5 até 7 s.m. & 9 \\
7 até 10 s.m. & 8 \\
& 10 até 14 s.m. & 3 \\
& 14 até 20 s.m. & 2 \\
& 20 s.m. ou mais & 3 \\
Total & & 55 \\
Renda familiar per capita & Até 1 s.m. & 21 \\
& 1 até 2 s.m. & 23 \\
& 2 até 4 s.m. & 6 \\
Total & 4 ou mais s.m. & 5 \\
\hline
\end{tabular}

Tabela 3.14 - Distribuição por turno da renda familiar per capita dos respondentes da UNIFESP.

\begin{tabular}{llll}
\hline Variáveis & Categorias & Diurno & Noturno \\
\hline Renda familiar per capita & Até 1 s.m. & 11 & 10 \\
& 1 até 2 s.m. & 13 & 10 \\
& 2 até 4 s.m. & 3 & 3 \\
Total & 4 ou mais s.m. & 3 & 2 \\
\hline
\end{tabular}

O valor da renda observado é compatível com os dados presentes no relatório da UNIFESP que apresenta o campus de Guarulhos como aquele que reúne a maior parte dos alunos com renda familiar de até cinco salários mínimos (Tabela 3.15). No interior desse campus (Tabela 3.16), o curso de Letras (Português vespertino e Português/Espanhol noturno) se destaca pela quantidade de alunos que recebem menos de cinco salários mínimos, seguido pelos cursos de Filosofia, Ciências Sociais e, por fim, Pedagogia.

Tabela 3.15 - Renda familiar dos ingressantes da UNIFESP por campus (2011).

\begin{tabular}{llllllll}
\hline Variável & Categorias & Baixada & Diadema & Guarulhos & Osasco & São J. Campos & São Paulo \\
\hline Renda UNIFESP & Nenhuma renda & 0 & 0 & 0,5 & 0,3 & 0,5 & 0 \\
& Até 5 s.m. & 50 & 49,3 & 64,2 & 33,7 & 46,2 & 32,4 \\
& $>5$ s.m. & 50 & 50,7 & 35,3 & 66 & 53,3 & 67,6 \\
\hline
\end{tabular}

Fonte: Pró-reitoria de Assuntos Estudantis - UNIFESP 
Tabela 3.16 - Cursos com a menor faixa de renda familiar dos ingressantes da UNIFESP de Guarulhos (2011).

\begin{tabular}{llll}
\hline Variáveis & Categorias & Até $\mathbf{5}$ s.m. & > 5 s.m. \\
\hline Renda Guarulhos & Ciências sociais noturno & 68,18 & 31,82 \\
& Ciências sociais vespertino & 68 & 32 \\
& Filosofia noturno & 74,47 & 25,53 \\
& Filosofia vespertino & 71,93 & 28,07 \\
& Letras (Por.) noturno & 73,91 & 26,09 \\
& Letras (Port.) vespertino & 85,72 & 14,28 \\
& Letras (Port./Esp.) noturno & 85 & 15 \\
& Pedagogia noturno & 66,03 & 33,97 \\
& Pedagogia vespertino & 54 & 46 \\
\hline
\end{tabular}

Fonte: Pró-reitoria de Assuntos Estudantis - UNIFESP

Quanto ao percurso formativo dos alunos da UNIFESP (considerando-se todos os campi), notou-se que a maior parcela dos candidatos aprovados foram formados em escolas particulares. Porém, mais uma vez o campus de Guarulhos se destaca ao ter entre seus ingressantes uma participação maior de alunos egressos de instituições de ensino médio públicas. Inserido neste quadro, o perfil dos respondentes do curso de Pedagogia também é marcado pelo predomínio da formação em estabelecimentos públicos, tal como ocorreu nos cursos de Serviço Social e licenciatura em Ciências. Chama a atenção, portanto, o fato dos cursos que recebem mais alunos negros serem os mesmos que aprovam também mais alunos formados em instituições públicas de ensino, estando incluso neste grupo o curso de Pedagogia.

Em termos de origem familiar, Guarulhos termina por reunir pais com menor nível de escolaridade e famílias com faixas de renda mais baixas. Do mesmo modo, os alunos de Pedagogia investigados possuem como rendimento mensal per capita mais comum valores que variam de menos um a até dois salários mínimos, enquanto a formação escolar do pai atinge até o ensino fundamental. As mães, por sua vez, superam a expectativa comum ao campus, possuindo de modo mais recorrente a formação escolar que se estende até o ensino médio.

Além das aproximações entre o campus de Guarulhos e os respondentes do curso de Pedagogia aqui investigados, o contato com os dados do relatório da UNIFESP permitiu a observação de algumas variações envolvendo os turnos em que o curso de Pedagogia é ministrado (Tabela 3.17). Notou-se, por exemplo, que há mais alunos negros estudando no período noturno, estando neste horário também o maior número de egressos da escola pública, apesar deste turno contar com uma nota de corte levemente superior. Outra característica distintiva deste turno diz respeito à faixa de renda mensal, menor que a das famílias dos estudantes do período vespertino. 
Tabela 3.17 - Diferença entre os turnos do curso de pedagogia ingressantes (2011).

\begin{tabular}{lllllll}
\hline Variável & Nota de corte & Negros & Escola pública & Escola particular & Renda $<5$ s.m. & Renda $>5$ s.m. \\
\hline Pedagogia vespertino & 673,97 & 30 & 60 & 40 & 54 & 46 \\
Pedagogia noturno & 678,16 & 50,94 & 81,13 & 18,87 & 66,03 & 33,97 \\
\hline
\end{tabular}

Fonte: Pró-reitoria de Assuntos Estudantis - UNIFESP

A percepção das diferenças entre os períodos acima descritas indicou a necessidade de verificar se as mesmas ocorreriam entre os respondentes participantes desta investigação. Como resultado, foram identificadas pequenas variações entre os mesmos (Tabela 3.18). Inicialmente, considerando as características gerais, foi verificado que a faixa etária do período diurno é mais baixa, enquanto no período noturno os jovens e os alunos com mais de trinta e um anos de idade distribuem-se de modo equilibrado. Outra característica do período noturno é que nele estuda a maior parte dos respondentes negros vinculados ao curso.

Tabela 3.18 - Distribuição do gênero, raça e posse de filhos entre os turnos da UNIFESP.

\begin{tabular}{lllll}
\hline Variáveis & Categorias & Diurno & Noturno & Total \\
\hline Sexo & Feminino & 26 & 19 & 45 \\
Total & Masculino & 4 & 6 & 10 \\
Faixa etária & & 30 & 25 & 55 \\
& 20 a 25 & 22 & 11 & 33 \\
Total & 26 a 30 & 3 & 4 & 7 \\
& 31 ou mais & 5 & 10 & 15 \\
Raça & & 30 & 25 & 55 \\
& Branco & 20 & 10 & 30 \\
& Pardo & 5 & 13 & 18 \\
& Preto & 3 & 2 & 5 \\
Total & Amarelo & 1 & 0 & 1 \\
& Indígena & 1 & 0 & 1 \\
Estado conjugal & & 30 & 25 & 55 \\
& Casado & 8 & 7 & 15 \\
Total & Solteiro & 21 & 17 & 38 \\
\multirow{2}{*}{ Filhos } & Separado & 1 & 1 & 2 \\
& & 30 & 25 & 55 \\
Total & Sim & 7 & 6 & 13 \\
\hline
\end{tabular}

Em termos de trajetória escolar (Tabela 4.19), nota-se uma significativa homogeneidade entre os turnos no que se refere às categorias dos estabelecimentos de ensino frequentados (público/privado) e quanto ao trabalho durante o ensino médio. Os alunos do período noturno tenderam a frequentar menos os cursinhos preparatórios para o vestibular, enquanto estão entre eles o maior número de alunos que concluíram cursos técnicos profissionalizantes durante o ensino médio. 
Tabela 3.19 - Distribuição por turno da trajetória escolar dos respondentes da UNIFESP.

\begin{tabular}{lllll}
\hline Variáveis & Categorias & Diurno & Noturno & Total ${ }^{12}$ \\
\hline Ensino fundamental & Público & 13 & 17 & 30 \\
& Privado & 10 & 7 & 17 \\
Ensino médio & Público & 17 & 17 & 34 \\
& Privado & 11 & 7 & 18 \\
Turno no ensino médio & Diurno & & & \\
& Noturno & 22 & 17 & 39 \\
Trabalho no ensino médio & & 8 & 8 & 16 \\
& & 14 & 12 & 26 \\
Frequentou cursinho & & & & \\
Modalidade do ensino médio & Regular & 13 & 5 & 18 \\
& Normal/magistério & 1 & 18 & 43 \\
& EJA & 2 & 1 & 2 \\
& Técnico profissionalizante & 2 & 5 & 7 \\
\hline
\end{tabular}

A respeito do nível de instrução familiar e ocupações desempenhadas (Tabela 3.20), foi possível verificar que, no período noturno, há maior destaque para os pais com formação até o ensino fundamental, enquanto no período diurno nota-se uma significativa heterogeneidade nesse sentido, havendo, porém, mais pais com formação universitária neste horário. As mães, por sua vez, contam nos dois turnos com maioria formada até o ensino médio. Para os demais níveis formativos, o mesmo quadro observado entre os pais se repete: há mais mães com ensino fundamental no período noturno, enquanto a formação superior se faz mais presente entre os alunos do período diurno. Quanto às ocupações elas seguem a mesma distribuição observada em relação ao nível formativo dos familiares destes respondentes, ou seja, é comum aos dois turnos os trabalhos braçais, entretanto, no período matutino há mais pais que dedicam seu tempo às ocupações que exigem formação universitária.

\footnotetext{
12 Os dados utilizados nesta tabela não incluem os alunos cuja formação foi assinalada como mista, ou seja, com passagem tanto pela escola pública quanto pela escola privada.
} 
Tabela 3.20 - Distribuição por turno do nível de instrução familiar e ocupações dos respondentes da UNIFESP.

\begin{tabular}{|c|c|c|c|c|}
\hline Variáveis & Categorias & Diurno & Noturno & Total \\
\hline \multirow[t]{4}{*}{ Instrução pai } & Até Ensino Fundamental & 8 & 14 & 22 \\
\hline & Ensino Médio & 10 & 8 & 18 \\
\hline & Superior ou Pós-graduação & 10 & 2 & 12 \\
\hline & Não sei & 2 & 1 & 3 \\
\hline Total & & 30 & 25 & 55 \\
\hline \multirow[t]{5}{*}{ Instrução mãe } & Até Ensino Fundamental & 8 & 9 & 17 \\
\hline & Ensino Médio & 13 & 13 & 26 \\
\hline & Superior ou Pós-graduação & 8 & 3 & 11 \\
\hline & Não frequentou escola & 1 & 0 & 1 \\
\hline & & 30 & 25 & 55 \\
\hline \multirow[t]{4}{*}{ Ocupação pai } & $\begin{array}{l}\text { Profissional liberal ou atividade profissional } \\
\text { com exigência formativa elevada. }\end{array}$ & 8 & 2 & 10 \\
\hline & $\begin{array}{l}\text { Serviços administrativos, comércio, serviços } \\
\text { técnicos e demais ocupações que exigem } \\
\text { formação escolar mediana. }\end{array}$ & 7 & 6 & 13 \\
\hline & $\begin{array}{l}\text { Trabalho manual, produção de bens e serviços } \\
\text { industriais e atividades profissionais que } \\
\text { exigem baixa exigência formativa. }\end{array}$ & 10 & 13 & 23 \\
\hline & Outros & 5 & 4 & 9 \\
\hline \multirow[t]{2}{*}{ Total } & & 30 & 25 & 55 \\
\hline & $\begin{array}{l}\text { Profissional liberal ou atividade profissional } \\
\text { com exigência formativa elevada. }\end{array}$ & 8 & 3 & 11 \\
\hline \multirow{3}{*}{ Ocupação mãe } & $\begin{array}{l}\text { Serviços administrativos, comércio, serviços } \\
\text { técnicos e demais ocupações que exigem } \\
\text { formação escolar mediana. }\end{array}$ & 4 & 9 & 13 \\
\hline & $\begin{array}{l}\text { Trabalho manual, produção de bens e serviços } \\
\text { industriais e atividades profissionais que } \\
\text { exigem baixa exigência formativa. }\end{array}$ & 16 & 10 & 26 \\
\hline & Outros & 2 & 3 & 5 \\
\hline Total & & 30 & 25 & 55 \\
\hline
\end{tabular}

As ações do governo federal voltadas para a expansão do ensino superior terminaram por aproximar da universidade um novo perfil discente, que costumeiramente não fazia parte desse espaço formativo. Fruto deste processo de expansão, o campus de Guarulhos da UNIFESP foi o que acolheu um perfil de alunado mais diferenciado e compatível com as intenções das políticas federais voltadas para a democratização do ensino superior. Entretanto, a associação do propósito do campus de oferecer formação na área de humanidades, ao perfil de seu alunado, indica a permanência na UNIFESP de uma ação seletiva vinculada à hierarquia existente entre os cursos oferecidos por esta universidade, uma vez que os alunos portadores de condições socioeconômicas mais privilegiadas destinam-se aos cursos das áreas de biológicas e ciências exatas, considerados de maior prestígio social. Essa mesma constatação foi feita por Zago (2006, p. 235) em seu estudo a respeito do percurso de estudantes universitários oriundos das camadas populares. Frente à percepção da diferença de status social dos alunos ingressantes, variável de acordo com a área de conhecimento, a autora denominou como "democratização segregativa" a seletividade social vivenciada pelos candidatos no momento de escolha da carreira. 
A distribuição não igualitária dos candidatos pelos diferentes cursos superiores demonstra o modo como a hierarquização das carreiras está fortemente associada à própria hierarquização dos diferentes grupos no interior da estrutura social, havendo uma representação desigual das classes sociais nos diferentes cursos de graduação. Trata-se, portanto, de um plano de democratização universitária, com realidade de reprodução, em que estudantes oriundos de famílias desprovidas econômica e culturalmente são encaminhados principalmente para cursos de menor valor social (BOURDIEU, 2013; 2014).

Esta hierarquização, como se viu, segue no interior do próprio campus, entre os cursos de humanidades, merecendo destacar o fato do curso de Pedagogia vespertino contar com a menor nota de corte do campus em 2011. Internamente ao curso de Pedagogia, os destaques ficam no âmbito do período noturno que recebeu o maior número de alunos negros, egressos de escolas públicas, cuja faixa de renda é mais baixa em relação às famílias dos alunos do vespertino. Ainda no período noturno a idade dos alunos é mais elevada, havendo entre eles o maior número de estudantes que trabalham enquanto se dedicam à sua formação universitária. Por fim, seus pais são menos escolarizados, uma vez que familiares detentores do diploma de ensino superior são mais comuns entre os alunos do período vespertino.

\subsection{AS PRÁTICAS CULTURAIS E O CONHECIMENTO DO SENTIDO DO JOGO}

O estudo do modo como os respondentes da UNIFESP ocupam seu tempo livre (Tabela 3.21) indicou que as atividades frequentemente praticadas, por mais da metade dos alunos, foram ouvir música, ler e cuidar da casa. O descanso e o acompanhamento de emissões televisivas também foram registradas como frequentes, porém, o volume de praticantes nestes casos já não abrange um número expressivo dentre os licenciandos investigados. 
Tabela 3.21 - Atividades mais frequentemente realizadas no tempo livre pelos respondentes da UNIFESP.

\begin{tabular}{|c|c|c|}
\hline Variáveis & Categorias & $\mathbf{n}$ \\
\hline \multirow[t]{4}{*}{ Ouvir música } & Frequentemente & 41 \\
\hline & Ocasionalmente & 6 \\
\hline & Raramente & 3 \\
\hline & Não resposta & 1 \\
\hline Total & & 51 \\
\hline \multirow[t]{3}{*}{ Leituras } & Frequentemente & 39 \\
\hline & Ocasionalmente & 10 \\
\hline & Raramente & 2 \\
\hline Total & & 51 \\
\hline \multirow[t]{5}{*}{ Cuidados com a casa } & Frequentemente & 25 \\
\hline & Ocasionalmente & 14 \\
\hline & Raramente & 7 \\
\hline & Nunca & 3 \\
\hline & Não resposta & 2 \\
\hline Total & & 51 \\
\hline \multirow[t]{4}{*}{ Descansar } & Frequentemente & 22 \\
\hline & Ocasionalmente & 12 \\
\hline & Raramente & 16 \\
\hline & Nunca & 1 \\
\hline Total & & 51 \\
\hline \multirow[t]{5}{*}{ Televisão } & Frequentemente & 21 \\
\hline & Ocasionalmente & 19 \\
\hline & Raramente & 7 \\
\hline & Nunca & 2 \\
\hline & Não resposta & 2 \\
\hline Total & & 51 \\
\hline \multirow[t]{3}{*}{ Cinema } & Frequentemente & 19 \\
\hline & Ocasionalmente & 22 \\
\hline & Raramente & 10 \\
\hline Total & & 51 \\
\hline
\end{tabular}

A tabela acima apresentada demonstra que o hábito de ouvir música foi relatado por um número representativo de alunos, uma vez que cerca de 4 em cada 5 respondentes o faz durante seu tempo livre. Reconhecendo a improbabilidade de alguém não ouvir música em algum momento do seu dia, mesmo que de forma indireta, convém mencionar que a demanda apresentada aos alunos no momento da pesquisa foi a de assinalarem as práticas realizadas em seu cotidiano, para as quais destinavam um momento específico do seu dia. Desse modo, para este grupo, há um valor significativo destinado a esta atividade. Com relação ao gosto musical dos respondentes, os gêneros mencionados por cerca de metade dos alunos foram aqueles relacionados à música brasileira (26/51): forró (1 menção), pagode (1 menção), samba (2 menções), sertanejo (4 menções) e MPB. A música popular brasileira (MPB), por sua vez, foi o gênero preferido pelo grupo, contando com dezoito menções considerando-se o conjunto da amostra de cinquenta e um respondentes. Outros gêneros musicais também foram indicados, tal como ilustra a Tabela 4.22: 
Tabela 3.22 - Distribuição dos gêneros musicais apreciados pelos respondentes da UNIFESP.

\begin{tabular}{ll}
\hline Gêneros musicais & $\mathbf{n}$ \\
\hline Blues & 1 \\
Eletrônica & 1 \\
Forró & 1 \\
Gospel & 3 \\
Jazz & 3 \\
MPB & 18 \\
Pagode & 1 \\
Pop & 6 \\
Rap & 1 \\
Rock & 9 \\
Samba & 2 \\
Sertanejo & 4 \\
\hline
\end{tabular}

No que se refere à prática da leitura, segunda atividade mais frequentemente desenvolvida, observou-se que os alunos preferem os livros aos jornais e revistas. A leitura de livros foi informada como prática muito frequente (24/51) ou regular (19/51) pela grande maioria dos respondentes. Contrariamente, apenas oito alunos afirmaram ler pouco, enquanto seis estudantes foram incapazes de citar o nome do último livro lido.

A partir da observação do gênero literário (Quadro 3.1), num total de quarenta e uma indicações ${ }^{13}$ de títulos de livros, foi possível identificar que aproximadamente metade dos alunos lê por prazer, ou seja, dedicam-se a esta atividade sem obrigação profissional ou escolar (21/41). Essa afirmação deve-se ao fato das obras mais citadas pertencerem ao âmbito da literatura, com clara preferência dos respondentes pelos romances estrangeiros. Em meio às obras mencionadas (Quadro 3.1) é possível identificar a recorrência de best sellers como $A$ menina que roubava livros (Markus Zusak), A dança dos dragões - As crônicas de gelo e fogo (George R. R. Martin) e Inferno (Dan Brown), e, em menor número, clássicos da literatura como O pequeno príncipe (Antoine de Saint-Exupéry), O velho e o mar (Ernest Hemingway); Os trabalhadores do mar (Victor Hugo) e 1984 (George Orwell). Muito menos expressiva entre as preferências dos alunos, a literatura nacional foi mencionada somente por quatro vezes. Dentre os autores nacionais, constam Aluísio de Azevedo (O Cortiço), Darcy Ribeiro (Confissões), Lobão (Manifesto do nada na terra do nunca) e Martha Medeiros (Doidas e Santas).

13 É importante mencionar que houve quarenta e cinco títulos citados, entretanto quatro deles não foram identificados, possivelmente por uma falha de registro por parte dos respondentes. 
Quadro 3.1 - Listagem dos livros lidos recentemente pelos respondentes da UNIFESP.

\begin{tabular}{|c|c|}
\hline Variáveis & Categorias \\
\hline Livros estrangeiros & $\begin{array}{l}1984 \text { (George Orwell) } \\
1 \text { Q84 (Haruki Murakami) } \\
\text { A casa das orquídeas (Lucinda Riley) } \\
\text { A caverna (José Saramago) } \\
\text { A dança dos dragões - As crônicas de gelo e fogo (George R. R. Martin) } \\
\text { A menina que roubava livros (Markus Zusak) } \\
\text { Férias (Marian Keyes) } \\
\text { Inferno (Dan Brown) } \\
\text { Infiel - A história de uma mulher que desafiou o Islã (Ayaan Hirsi Ali) } \\
\text { Kilaim - Águas Turvas (Daniel Mastral) } \\
\text { O caminho (Richard Paul Evans) } \\
\text { O jogo do anjo (Carlos Ruiz Zafón) } \\
\text { O mundo de Sofia (Jostein Gaarder) } \\
\text { O nome do vento (Patrick Rothfuss) } \\
\text { O pequeno príncipe (Antoine de Saint-Exupéry) (2) } \\
\text { O velho e o mar (Ernest Hemingway) } \\
\text { Os trabalhadores do mar (Victor Hugo) }\end{array}$ \\
\hline Livros nacionais & $\begin{array}{l}\text { Confissões (Darcy Ribeiro) } \\
\text { Doidas e Santas (Martha Medeiros) } \\
\text { Manifesto do nada na terra do nunca (Lobão) } \\
\text { O cortiço (Aluísio de Azevedo) }\end{array}$ \\
\hline Educação & $\begin{array}{l}\text { A produção do fracasso escolar (Maria H. Souza Patto) } \\
\text { Como brincam as crianças surdas (Daniele Nunes H. Silva) } \\
\text { Do silêncio do lar ao silêncio escolar: racismo, preconceito e discriminação na educação } \\
\text { infantil (Eliane dos Santos Cavalleiro) } \\
\text { Educar meninas e meninos: relações de gênero na escola (Daniela Auad) } \\
\text { Foucault, Deleuze \& Educação (Sônia M. Clareto e Anderson Ferrari) } \\
\text { Língua estrangeira para crianças: ensino-aprendizagem e formação docente (Claudia H. } \\
\text { Rocha; Kleber A. Silva e Juliana R. A. Tonelli) } \\
\text { O espaço do desenho: a educação do educador (Ana A. Albano) (2) } \\
\text { Os sentidos da alfabetização (Maria do Rosário L. Mortatti) }\end{array}$ \\
\hline Religioso & $\begin{array}{l}\text { A anatomia de uma dor - um luto em observação (Clive S. Lewis) } \\
\text { Ágape (Marcelo Rossi) } \\
\text { Janelas da alma (Ken Gire) } \\
\text { Paulo, um homem de coragem e graça (Charles R. Swindoll) }\end{array}$ \\
\hline $\begin{array}{l}\text { História; Linguagem; } \\
\text { Psicologia e Sociologia }\end{array}$ & $\begin{array}{l}\text { Cultura de massa e cultura popular: leituras operárias (Ecléa Bosi) } \\
\text { Decifrar pessoas (Jo-ellan Dimitrius; Wendy P. Mazzarella) } \\
\text { Eichmann em Jerusalém (Hannah Arendt) } \\
\text { Não violência: a história de uma ideia perigosa (Mark Kurlansky) } \\
\text { O segundo sexo (Simone de Beauvoir) }\end{array}$ \\
\hline
\end{tabular}

Contrapondo-se à leitura de fruição, a segunda classificação de livros mais mencionados foram aqueles relacionados à educação, num total de oito citações (8/41). Entre os títulos é possível notar a presença de obras relativas às práticas escolares, filosofia, psicologia, educação especial e relações raciais e de gênero. Ainda no campo da literatura de informação, obras das áreas da sociologia, filosofia, história, linguagem e psicologia foram referidas (4/41) destacando-se autores como Ecléa Bosi, Hannah Arendt e Simone de Beauvoir.

Indagados a respeito do costume da realização de leituras de revistas e jornais, notouse que estas fontes de informação são pouco utilizadas por estes respondentes (Tabela 3.23). Nos dois casos, os alunos concentraram suas respostas em "leio pouco" e "não leio". Entre os supostos leitores de revistas, dos seis alunos que afirmaram ler muito, dois não conseguiram 
indicar o nome de nenhuma revista específica, havendo um elevado grau de imprecisão em suas respostas: "Decoração/festas" e "Todas”. O mesmo ocorreu com um aluno que se identificou como leitor regular, afirmando que as revistas por ele lidas são "As que distribuem gratuitamente no mercado". Tais declarações demonstram a existência, entre os leitores de revistas que se autodenominaram assíduos, de uma clara ausência de familiaridade com esse tipo de publicação, além da incapacidade de ao menos reconhecerem a legitimidade e não legitimidade de determinadas fontes de informação.

\section{Tabela 3.23 - Frequência da leitura de revistas e jornais entre os respondentes da} UNIFESP.

\begin{tabular}{lll}
\hline Variáveis & Categorias & $\mathbf{n}$ \\
\hline Revistas & Leio muito & 6 \\
& Leio regularmente & 5 \\
& Leio pouco & 28 \\
\multirow{4}{*}{ Total } & Não leio & 12 \\
& & 51 \\
Jornais & Leio muito & 6 \\
& Leio regularmente & 7 \\
& Leio pouco & 24 \\
Total & Não leio & 14 \\
& & 51 \\
\hline
\end{tabular}

Considerando-se as categorias das publicações, é possível notar o interesse dos respondentes por revistas que tratam de atualidades, curiosidades culturais e científicas, educação e outras, especificamente voltadas para temas da política, economia, cultura e sociedade. Com menor incidência, revistas femininas também foram mencionadas, do mesmo modo que publicações especializadas em esporte, música, religião, informática e pesquisa científica. É importante observar que, no caso das revistas, não foi expresso de modo significativo o "gosto de necessidade" por parte destes estudantes, uma vez que apesar da existência dos que se interessam pelas publicações educacionais, seu número de leitores é reduzido frente à diversidade temática dos demais periódicos.

A observação detida dos títulos das publicações indicadas pelos respondentes (Quadro 3.2) permite afirmar que parte das que possuem maior recorrência (Veja, Isto É, Época, Superinteressante e Nova Escola) estão entre as dez mais vendidas na região sudeste do país, de acordo com o Instituto Verificador de Comunicação (IVC) ${ }^{14}$. Com similaridade temática e de conteúdos, as revistas Veja, Época e Isto É publicam artigos de assuntos gerais, tais como economia, política, saúde, entretenimento, esporte, educação, ciência e tecnologia, meio ambiente e comportamento, além da divulgação de notícias sobre acontecimentos do

\footnotetext{
${ }^{14}$ Segundo dados recolhidos no primeiro semestre de 2014.
} 
Brasil e do mundo. A revista Superinteressante, por sua vez, publica textos de curiosidades nas áreas de ciências exatas, humanas, biológicas e religião, ao passo que a Nova Escola trata especificamente da temática educacional.

\section{Quadro 3.2 - Listagem das revistas lidas pelos respondentes da UNIFESP.}

\begin{tabular}{|ll|}
\hline Categorias & Títulos \\
\hline Atualidades & Época (4); IstoÉ (4) e Veja (5) \\
\hline Curiosidades culturais e científicas & $\begin{array}{l}\text { Globo Ciência; Mundo Estranho (2) e } \\
\text { Superinteressante (4) }\end{array}$ \\
\hline Educação & $\begin{array}{l}\text { Carta na Escola; Nova Escola (5); Revista Educação; } \\
\text { Revista Educação \& Sociedade }\end{array}$ \\
\hline Política, economia, cultura e sociedade & Caros Amigos (3) e Carta Capital (4) \\
\hline Revistas especializadas & Bikemagazine; Cristianismo hoje; Fapesp; Guitar \\
\hline Revistas femininas & AnaMaria; Elle e Máxima \\
\hline
\end{tabular}

Enquanto publicações como Veja, IstoÉ e Época se destacam pela circulação em meio ao grande público, seja pela variedade das informações que divulgam, como pelo estilo simples e direto de seus textos, é importante ressaltar a ocorrência de menções, entre os respondentes da UNIFESP, de revistas como Caros Amigos e Carta Capital, as quais possuem como característica um jornalismo de conteúdo mais denso, crítico e reflexivo e, por este motivo, detentor de uma circulação mais restrita e elitizada no mercado editorial.

Do mesmo modo que as revistas, a leitura de jornais não se apresenta como prática frequente, uma vez que um número significativo de respondentes (38/51) declarou não ter o hábito de leitura desse tipo de periódico. Tal como ocorreu na indicação dos títulos das revistas, um pequeno número de alunos, na tentativa de apontar o nome de algum jornal por eles acompanhado, apresentaram registros imprecisos ("notícias"; “todos”) e confusos (indicação da revista Carta Capital como o "jornal" mais lido) que, longe de dissimular seu desconhecimento, terminaram por evidenciar a ausência da familiaridade dos mesmos com esse tipo de fonte de informação.

Dentre os jornais mais referidos pelos respondentes constam Estado de S. Paulo, com 17 citações, e Folha de S. Paulo, com 18 citações, dado esperado diante do fato destes jornais serem os de maior circulação no estado de São Paulo. Jornais populares, regionais e de distribuição gratuita também foram apresentados como objeto de leitura dos respondentes, tais como Diário do Grande ABC (1 citação); Folha Metropolitana (2 citações), Diário de S. Paulo (2 citações), Metrô News (1 citação) e “jornal do bairro” (1 citação). Por outro lado, uma pequena parcela de respondentes $(3 / 51)$ indicou o hábito da leitura de jornais pouco conhecidos 
entre o grande público, tal como o semanário de circulação nacional Brasil de Fato. Lançado no Fórum Social Mundial de Porto Alegre, em 2003, o jornal Brasil de Fato foi criado por movimentos sociais como o Movimento dos Trabalhadores Rurais Sem Terra (MST), a Via Campesina, a Consulta Popular e as pastorais sociais, tendo em vista participar de debates políticos a respeito da necessidade de promoção de mudanças sociais no Brasil. Nesta mesma modalidade de publicação, restrita ao grande público, voltada para temáticas sociais e portadora de um ideário político esquerdista, foram citados os seguintes jornais: Adital; Carta Maior; Outras palavras e Pragmatismo Político, sendo os mesmos de divulgação exclusivamente digital. Por fim, dois respondentes indicaram o hábito de lerem o jornal Le Monde Diplomatique Brasil, publicação mensal que trata prioritariamente de temas relacionados à economia, cultura, política e relações internacionais, também portador de uma perspectiva ideológica esquerdista.

As declarações dos respondentes da UNIFESP a respeito do seu gosto musical e de suas práticas de leitura permitiram identificar duas variações de práticas culturais. Uma primeira, mais próxima do gosto popular, e outra que se aproxima do gosto legítimo. Iniciando pelos hábitos musicais, enquanto parte dos alunos manifestou interesse pelos gêneros sertanejo, pagode, forró e música religiosa, consumidos pelos grupos sociais menos privilegiados, outra parte dos respondentes manifestou interesse por MPB, jazz, blues e rock, cuja preferência está associada a maiores níveis de formação escolar e renda (BOTELHO; FIORE, 2005). À mesma conclusão chegou o IBOPE Media, em pesquisa desenvolvida no ano de 2013, a respeito dos ritmos musicais preferidos pelos brasileiros ${ }^{15}$. Neste trabalho notou-se que os ouvintes de MPB, jazz, blues, música clássica e rock pertencem às classes sociais mais favorecidas economicamente, além destes gêneros contarem com a adesão de um maior número de portadores do diploma universitário.

Quanto ao hábito da leitura, deve-se destacar a relevância da prática por prazer entre os respondentes da UNIFESP, sendo esta atividade por si mesma distintiva se considerarmos a fruição cultural como símbolo de status, ao se distanciar das leituras funcionais, comuns às classes populares. Enquanto o desinteresse caracteriza a contemplação estética dos agentes que ocupam as posições mais privilegiadas no interior da estrutura social, em meio às classes populares procura-se nas obras alguma utilidade, sem a qual as mesmas são compreendidas como supérfluas ou desnecessárias (BOURDIEU, 2007).

\footnotetext{
${ }^{15}$ Pesquisa realizada pelo IBOPE Media no ano de 2013 disponibilizada em: < http://www.ibope.com.br/ptbr/conhecimento/Infograficos/Paginas/Tribos-Musicais.aspx>. Acesso em: 03 mai 2015.
} 
Apesar da presença dos best sellers na listagem dos livros lidos recentemente, a observação detida das obras referidas sugere a existência de um perfil mais intelectualizado, por parte de alguns alunos, expresso pela indicação de leitura de obras clássicas da literatura, bem como de autores contemporâneos reconhecidos pela crítica literária como José Saramago e Haruki Murakami. No campo das produções acadêmicas, é impossível deixar de notar o interesse diversificado de alguns alunos por temas que ultrapassam as questões educacionais, voltando-se para as áreas de sociologia, história, filosofia entre outras, com a presença de autores cuja obra é reconhecida por sua densidade e relevância.

O mesmo ocorreu quando os alunos informaram seus hábitos de leitura de jornais e revistas. Ao lado da menção a periódicos extremamente populares, portadores de conteúdo simplório e de fácil assimilação, como as revistas AnaMaria e Máxima, e os jornais Diário de S. Paulo, Diário do Grande ABC e Metrô News, foram identificadas menções a fontes de informação periódicas portadoras de conteúdos mais densos e reflexivos, não destinadas ao mercado comercial e ao atendimento do grande público.

Segundo Bourdieu (2007), as práticas culturais possuem relação com a diversidade de posições ocupadas pelos agentes no interior do espaço social, variáveis de acordo com o volume detido dos capitais econômico, social e cultural. De modo geral, as relações legítimas com a cultura estão associadas ao pertencimento do agente a famílias detentoras de uma elevada bagagem cultural e que, de acordo com seu poderio econômico, são capazes de proporcionar experiências formativas diversificadas, internas ou externas ao ambiente doméstico. Dependente, portanto, de condições específicas de socialização, a formação cultural distintiva resulta da aquisição de uma competência estética original, adquirida mediante uma aprendizagem espontânea e difusa, consequência da simples inserção do agente em um dado grupo familiar.

No caso dos alunos aqui investigados, o estudo acerca de sua origem social indicou o pertencimento dos mesmos às camadas sociais de menor poder aquisitivo, uma vez que o rendimento familiar mensal per capita comum ao grupo variou de menos um a até dois salários mínimos mensais. Quanto ao perfil formativo de seus pais, foi identificado que as mulheres geralmente alcançaram a formação escolar de nível médio, enquanto os homens atingiram em maior número o ensino fundamental. Em termos profissionais, independentemente do sexo, os pais destes alunos dedicam-se a ocupações pouco qualificadas, caracterizadas pelo trabalho manual. 
Diante deste quadro, as práticas culturais esperadas em meio a este grupo de respondentes seriam certamente vinculadas aos hábitos característicos das classes populares. Previsão confirmada ao observarmos que o tempo livre dos alunos é muito pouco dedicado ao exercício do lazer cultural. Este, quando realizado, destinou-se predominantemente à escuta de músicas e às atividades de leitura, tal como apresentado anteriormente. Para além destas duas atividades, os respondentes da UNIFESP declararam utilizar seu tempo livre também para o cuidado da casa, para o descanso, assistência à TV e idas ao cinema. Nota-se, portanto, que prevalecem as atividades desenvolvidas no ambiente doméstico, próximas do cumprimento das obrigações pessoais e da necessidade de reposição da força de trabalho. Deve-se destacar os números que indicam a falta de tempo para o descanso, sendo esta uma prática rara e ocasional para uma parcela significativa deste grupo (29/51), informação que reforça, para além da origem social dos alunos, o comportamento de baixo consumo cultural dos mesmos.

A frequência ao cinema, comportamento mais eventual e raro (32/51), do que frequente $(19 / 51)$, representa a prática de lazer realizada em ambiente externo ${ }^{16}$ de maior recorrência em meio ao grupo investigado. No que se refere à indicação dos nomes dos filmes, foi contabilizada a ocorrência do registro de trinta e nove títulos, dos quais dois não foram identificados, enquanto doze alunos não responderam a questão. A observação do gênero das produções indica a preferência pelos filmes de ação, animação, aventura e comédias (Quadro 3.3). Os títulos mencionados indicam a recorrência de produções norte-americanas, de grande sucesso comercial, tais como "Guerra Mundial Z", "Homem de Ferro 3", "Meu Malvado Favorito 2" e "Velozes e furiosos 6". Essa seleção cinematográfica repete-se em meio às produções nacionais, caracterizadas por um elenco conhecido dos canais de televisão e envoltas em grande divulgação publicitária, que experimentaram relativo sucesso de público nas salas de exibição brasileiras.

\footnotetext{
${ }^{16}$ Neste caso optamos por diferenciar as práticas culturais domiciliares (assistir tv, ouvir música, ler...), das práticas culturais externas (ir ao teatro, cinema, museu...), ou seja, realizadas fora de casa.
} 
Quadro 3.3 - Listagem do último filme visto no cinema - UNIFESP.

\begin{tabular}{|l|l|}
\hline Cinema americano & $\begin{array}{l}\text { Amor pleno (2013); As Aventuras de Pi (2012); Avatar (2009); Depois da Terra } \\
\text { (2013); Guerra Mundial Z (3) (2013); Homem de Aço (2013); Homem de Ferro } 3 \\
\text { O Cavaleiro Solitário (2) (2013); Oz: Mágico e Poderoso (2) (2013); Truque de } \\
\text { mestre (2013); Turbo (2013); Um homem de sorte (2012); Universidade Monstros } \\
\text { (3) (2013) e Velozes e furiosos 6 (2013) }\end{array}$ \\
\hline Cinema europeu & Hannah Arendt (2013); O artista (2012) e Os amantes passageiros (2013) \\
\hline Cinema nacional & $\begin{array}{l}\text { Besouro (2009); Faroeste Caboclo (2013); Gonzaga - De pai para filho (2012); } \\
\text { Minha mãe é uma peça (2) (2013); O concurso (2013); Pedra da Memória (2011) } \\
\text { e Somos tão jovens (2013) }\end{array}$ \\
\hline
\end{tabular}

As demais práticas culturais não domiciliares (Tabela 3.24) contaram com uma baixa adesão entre os respondentes, uma vez que a frequência a concertos, teatros, shows e museus foi muito pouco expressiva. Também se apresentaram como pouco comuns, as iniciativas que envolvem as práticas esportivas, viagens e visitações a parques, tal como demonstra a Tabela 3.24: 
Tabela 3.24 - Atividades culturais e de lazer realizadas com pouca frequência pelos respondentes da UNIFESP.

\begin{tabular}{|c|c|c|}
\hline Variáveis & Categorias & $\mathrm{n}$ \\
\hline Teatro & $\begin{array}{l}\text { Frequentemente } \\
\text { Ocasionalmente } \\
\text { Raramente } \\
\text { Nunca }\end{array}$ & $\begin{array}{l}3 \\
17 \\
28 \\
3\end{array}$ \\
\hline Total & & 51 \\
\hline Concertos & $\begin{array}{l}\text { Frequentemente } \\
\text { Ocasionalmente } \\
\text { Raramente } \\
\text { Nunca }\end{array}$ & $\begin{array}{l}4 \\
11 \\
19 \\
17 \\
51\end{array}$ \\
\hline Viagem & $\begin{array}{l}\text { Frequentemente } \\
\text { Ocasionalmente } \\
\text { Raramente } \\
\text { Nunca } \\
\text { Não resposta }\end{array}$ & $\begin{array}{l}5 \\
26 \\
16 \\
3 \\
1 \\
51\end{array}$ \\
\hline Shows & $\begin{array}{l}\text { Frequentemente } \\
\text { Ocasionalmente } \\
\text { Raramente } \\
\text { Nunca } \\
\text { Não resposta }\end{array}$ & $\begin{array}{l}6 \\
18 \\
19 \\
7 \\
1 \\
51\end{array}$ \\
\hline Museus & $\begin{array}{l}\text { Frequentemente } \\
\text { Ocasionalmente } \\
\text { Raramente } \\
\text { Não resposta }\end{array}$ & $\begin{array}{l}8 \\
21 \\
21 \\
1 \\
51\end{array}$ \\
\hline Esporte & $\begin{array}{l}\text { Frequentemente } \\
\text { Ocasionalmente } \\
\text { Raramente } \\
\text { Nunca } \\
\text { Não resposta }\end{array}$ & $\begin{array}{l}8 \\
9 \\
19 \\
14 \\
1 \\
51\end{array}$ \\
\hline Parques & $\begin{array}{l}\text { Frequentemente } \\
\text { Ocasionalmente } \\
\text { Raramente } \\
\text { Nunca }\end{array}$ & $\begin{array}{l}9 \\
29 \\
11 \\
2 \\
51\end{array}$ \\
\hline
\end{tabular}

Os dados de pesquisa aqui obtidos estão muito próximos dos resultados da investigação conduzida pelo Centro de Estudos da Metrópole a respeito das práticas culturais na região metropolitana de São Paulo. De acordo com Botelho e Fiore (2005), o acompanhamento de peças de teatro e concertos, além das visitas a museus são fracamente disseminados considerando-se as faixas mais amplas da população. Por outro lado, assim como Bourdieu (2007) já havia identificado, tais práticas se tornam mais comuns em meio aos grupos portadores de níveis elevados de escolaridade e renda.

Apesar das idas ao teatro e museus terem sido identificadas como práticas pouco expressivas, convém apresentar os títulos da última peça de teatro assistida e os nomes de seus museus preferidos, tendo em vista ampliar o conhecimento a respeito do consumo cultural destes respondentes. Iniciando pelo teatro, trinta e quatro alunos não souberam informar o nome 
da última apresentação assistida. Ao todo, foram registrados dezessete títulos de peças teatrais, assim divididos por gênero: 6 musicais; 5 comédias; 4 dramas e 2 autos. Como observado no Quadro 3.4, destaca-se uma certa predileção pelos espetáculos divulgados na mídia ("Rei Leão, o musical", "Rock in Rio, o musical") e referências a peças de teatro vinculadas a obras literárias conhecidas do grande público ("Vidas secas"; "Ilíada", "O auto da barca do inferno"). Assim como ocorreu na seleção dos filmes e boa parte dos livros, nota-se nas escolhas dos espetáculos teatrais a preferência pelas temáticas leves, exemplificadas pelas comédias e musicais, demonstrando que as atividades culturais dos respondentes estão voltadas para o entretenimento, exigindo pouco de seu público em termos de formação cultural. De acordo com Bourdieu (2007), o interesse atribuído aos diferentes tipos de produções culturais varia de acordo com a posse do capital cultural. Assim, quanto maior a legitimidade cultural da obra tomada como objeto de interesse do agente, maior será seu volume de capital cultural, adquirido nos meios familiar ou escolar.

\section{Quadro 3.4 - Lista da última peça de teatro assistida - UNIFESP.}

\begin{tabular}{|c|c|c|}
\hline & Títulos mencionados & Não souberam informar \\
\hline Teatro & $\begin{array}{l}\text { A barca do inferno; A farsa da justiça burguesa; A } \\
\text { princesinha, o musical; Agreste; Blefes Excêntricos; } \\
\text { Cabaré do avesso; Como se tornar uma super mãe } \\
\text { em } 10 \text { lições; Ilíada; Improvável; O auto da barca do } \\
\text { inferno; O fino no samba; Rei Leão, o musical (3); } \\
\text { Rock in Rio, o musical (2) e Vidas secas. }\end{array}$ & 34 alunos \\
\hline
\end{tabular}

Considerando-se as visitas aos museus, prática ocasional e rara para um número expressivo de alunos (42/51), foi possível identificar quarenta e oito menções aos locais de visitação preferidos pelos estudantes. Os museus que tiveram seus nomes registrados mais de uma vez foram: Pinacoteca do Estado de São Paulo (9 menções); Museu Lasar Segall (8 menções); Museu Paulista (6 menções); Museu da Língua Portuguesa (5 menções) e Museu de Arte Sacra (2 menções), indicando que o interesse por estes espaços variou dos museus de arte, aos museus históricos. Por fim, vale ressaltar a ocorrência da indicação de dois museus internacionais em meio aos relatos dos alunos: trata-se do Museu do Louvre, localizado em Paris, e o Museu Nacional Centro de Arte Reina Sofia, situado em Madri.

O estudo das práticas culturais dos respondentes da UNIFESP permitiu identificar um perfil significativamente homogêneo. Trata-se de alunos que ocupam seu tempo livre dedicando-se prioritariamente à escuta musical, à leitura e aos cuidados com a casa. O descanso e o acompanhamento de emissões televisivas também foram registrados, porém de forma menos 
frequente. Há que se considerar a influência das limitações financeiras como contribuintes desse comportamento: a necessidade de conciliar trabalho e estudo faz com que sobre pouco tempo livre para os alunos se dedicarem às atividades de lazer cultural. Outra repercussão do baixo capital econômico também pode observada na predileção por atividades culturais realizadas no meio doméstico, que não exigem investimento financeiro extra para serem empreendidas. Notase, portanto, a manifestação de um "gosto de necessidade" que termina por restringir as práticas culturais às condições objetivas de vida (BOURDIEU, 2007), fazendo com que o consumo por práticas culturais externas seja baixo entre estes respondentes. Não só a frequência a concertos, teatros, shows e museus foi muito pouco expressiva, como também a assistência de filmes no cinema, embora esta seja considerada a atividade externa mais disseminada entre as classes populares (BOTELHO; FIORE, 2005).

As inclinações culturais identificadas entre os agentes constituem-se como a manifestação dos condicionamentos primários aos quais os mesmos foram submetidos ao longo de suas vivências sociais. Neste processo, a família e a escola possuem papeis decisivos como instituições que exercem uma influência estruturante sobre os agentes, fornecendo-lhes disposições específicas que afetam seus modos de pensamento e ação. Tendo em vista a caracterização econômica e cultural de origem destes alunos, associada às camadas sociais menos privilegiadas, pode-se notar uma clara correspondência entre a condição social de origem dos respondentes e a relação simplificada com os bens culturais mantida pelos mesmos.

Para além do capital cultural e dos condicionamentos financeiros como fatores decisivos para a adoção de determinadas condutas frente à cultura, deve-se considerar também a localização da residência dos alunos e a disponibilidade de acesso aos equipamentos culturais existentes nas imediações de suas casas. De acordo com Bourdieu (2007), é inegável a relação existente entre os agentes que acumulam uma grande diversidade de práticas culturais e a localização de sua moradia em regiões que disponibilizam uma variedade significativa de espaços voltados à cultura. No caso dos estudantes de Pedagogia da UNIFESP aqui investigados identificou-se, conforme a Tabela 3.25, que grande parte vive nos municípios de São Paulo (32/55) e Guarulhos (11/55). Os demais distribuíram-se em cidades variadas da Região Metropolitana de São Paulo: Arujá (1); Barueri (1); Carapicuíba (1); Jandira (1); Mauá (1); Osasco (1); Santo André (1); São Bernardo do Campo (2) e Taboão da Serra (1). Por fim, somente um aluno indicou morar no interior de São Paulo, no município de Cerquilho, localizado na Região Metropolitana de Sorocaba. Observando os bairros do município de São 
Paulo, constatou-se uma leve predominância de alunos moradores da zona leste (11/32), região mais próxima do município de Guarulhos, local onde a universidade está instalada.

\section{Tabela 3.25 - Bairros ocupados pelos respondentes da UNIFESP no município de São} Paulo.

\begin{tabular}{lll}
\hline Regiões de SP & Bairros & n \\
\hline Centro & Barra Funda e República & 2 \\
Zona Leste & Cangaíba, Itaim Paulista, Mooca, São Mateus, São & 11 \\
Zona Norte & Miguel, Tatuapé e Vila Curuçá & Casa Verde, Jaçanã, Santana, Tremembé e Vila Maria \\
Zona Oeste & Butantã, Cachoeirinha, Perdizes e Pinheiros & 6 \\
Zona Sul & $\begin{array}{l}\text { Capão Redondo, Cursino, Grajaú, Ipiranga, Itaim Bibi, } \\
\text { Pedreira e Saúde }\end{array}$ & 8 \\
\hline
\end{tabular}

No município de São Paulo os equipamentos culturais são distribuídos de maneira desigual, havendo uma grande concentração dos mesmos na região central e bairros ocupados por uma população com maior faixa de renda. Essa divisão decorreu de uma organização do espaço urbano, iniciada no século XX, em que as áreas dedicadas ao lazer, às artes e manifestações musicais foram estabelecidas nas regiões de convivência e sociabilidade das elites paulistanas. Como consequência, a cidade assumiu feições desiguais quando se considera o centro e as regiões periféricas. Aquele primeiro, voltado às elites, passou a abranger cinemas, teatros e museus, enquanto na periferia tais equipamentos eram praticamente inexistentes, com exceção do cinema cujas primeiras salas foram instaladas nos bairros operários de São Paulo (BÓGUS; PASTERNAK, 2011).

Esse modo de divisão dos equipamentos de cultura terminou prevalecendo até os dias de hoje, tal como comprova a pesquisa de Nakagawa (2011), que investigou a atual distribuição dos equipamentos de cultura e lazer no município de São Paulo. De acordo com seu trabalho, equipamentos culturais como museus, teatros e salas de cinemas encontram-se localizados prioritariamente na área do centro expandido. Assumindo a mesma divisão administrativa utilizada pela Companhia de Engenharia de Tráfego, verificou-se, portanto, que os bairros mais privilegiados nesse sentido são: Sé, República, Bom Retiro, Santa Cecília, Liberdade, Cambuci, Consolação, Bela Vista, Brás, Belém, Mooca, Ipiranga, Vila Mariana, Moema, parte do distrito Saúde, Jardim Paulistano, parte do distrito do Itaim Bibi, Pinheiros, Alto de Pinheiros, Vila Leopoldina, Lapa, Perdizes e Barra Funda.

Procedendo ao confronto dos bairros ocupados pelos respondentes da UNIFESP com aqueles que concentram os equipamentos culturais, nota-se que os alunos estão localizados justamente nos bairros de São Paulo menos privilegiados nesse sentido. A zona leste, em especial, possui como característica a baixa cobertura de sua região por equipamentos públicos 
que favoreçam as práticas culturais. Além de bibliotecas, nestas localidades, os espaços de cultura disponibilizados para a população estão praticamente reduzidos aos Centros Educacionais Unificados (CEU's), afora duas unidades do Serviço Social do Comércio (SESC). Quanto ao cinema, convém destacar que nas regiões periféricas os mesmos encontram-se situados no interior dos shoppings, nem sempre próximos dos bairros mais desprovidos.

Considerando-se os bairros de Guarulhos ocupados pelos respondentes, apesar do município não possuir uma rede diversificada de espaços culturais, foi possível notar a existência de salas de teatro em três bairros ocupados pelos estudantes, sendo, entretanto, mais comum no município a disponibilização de bibliotecas públicas. As salas de cinema estão restritas aos shoppings da cidade, os quais possuem como característica a exibição de filmes que experimentam maior sucesso comercial. Quanto aos museus, o município conta com a existência de dois: o Museu Histórico Municipal e o Museu de Ciências Naturais.

A partir do confronto entre a distribuição dos equipamentos de cultura nos municípios de São Paulo e Guarulhos (os mais amplamente povoados pelos alunos em questão) e as práticas culturais dos respondentes, é possível considerar que o modesto envolvimento dos mesmos com estas atividades tem a ver com a localização de suas residências e as possibilidades limitadas de acesso a salas de concerto, teatros, museus e cinemas. Tomando especificamente a prática de consumo cinematográfico, a identificação dos alunos com filmes norte-americanos de grande sucesso comercial ou produções nacionais de caráter popular, pode resultar do fato das salas de cinema acessíveis a este grupo serem aquelas existentes nas áreas de lazer de shoppings centers, as quais, com raras exceções, exibem produções justamente com essas características. Este caso seria, portanto, um exemplo do modo como as limitações geográficas atuariam como fator de diferenciação das práticas culturais dos agentes.

Pesquisas que tratam da distribuição dos equipamentos culturais pelas diversas regiões da cidade apontam constantemente a existência de uma condição desequilibrada na difusão dos mesmos. Considerando-se as dificuldades envolvidas nos deslocamentos físicos no interior das cidades, o acesso aos espaços de cultura termina por constituir como algo facilitado às classes sociais de maior poder aquisitivo e que vivem nas regiões mais bem estruturadas dos municípios. Porém, a existência de equipamentos culturais nas proximidades das residências não se constitui como fator decisivo que impele o público vizinho a fazer uso dos mesmos. Por um longo período, existiu a crença de que o contato do público com a obra seria suficiente para promover o gosto pelas práticas culturais, contudo, a experiência mostrou que públicos diferentes reagem de modos distintos diante da mesma oferta de equipamentos culturais. Assim, 
uma análise ampla das práticas culturais deve levar em consideração um conjunto de fatores: além da facilidade de acesso a museus, teatros e cinemas, a utilização desses espaços depende da diversidade dos padrões culturais, que resulta da condição de classe dos agentes: sua origem econômica, social, bagagem cultural familiar e trajetória escolar (BOTELHO, 2004).

Embora a caracterização geral das práticas culturais dos respondentes da UNIFESP indique o baixo consumo de quase todos os itens investigados, em certos momentos da pesquisa foram identificados registros que demonstraram, por parte de alguns alunos, a posse de um comportamento cultural distintivo. As práticas diferenciadas foram notadas no gosto musical, na escolha das leituras e de algumas produções cinematográficas.

Considerando as observações de Bourdieu (2007) acerca das variações das práticas culturais decorrentes da constituição de uma competência dada inicialmente pela origem social, seguida pela formação escolar experimentada pelos indivíduos, foi percebida a necessidade de verificar se a diferenciação constatada se relacionava com a existência de um perfil socioeconômico e cultural específico de alguns alunos em relação aos demais.

O trabalho de investigação foi iniciado com a identificação dos alunos que ofereceram respostas distintivas, seguida por uma análise detalhada do nível de escolaridade e ocupação de seus pais; renda familiar per capita mensal e trajetória escolar dos respondentes. Como resultado, notou-se que em termos de origem social, poucos pertencem a famílias que ultrapassaram a faixa média de até dois salários mínimos per capita, enquanto o nível de instrução familiar também não se distinguiu do resultado geral verificado no grande grupo de respondentes da instituição. Quanto à trajetória escolar destes alunos, observou-se o predomínio da formação em escolas públicas, de ensino médio regular, cursado no período matutino, repetindo o perfil formativo observado em meio à totalidade dos respondentes da UNIFESP.

Há, portanto, uma condição bastante particular em meio aos respondentes que, apesar de possuírem uma origem social significativamente homogênea, se distinguem em termos de práticas culturais. De acordo com Bourdieu (2007), as práticas culturais não se relacionam com o gosto ou com os interesses individuais, mas estão grandemente subordinadas aos determinismos sociais. Tais determinismos atuam como disposições responsáveis pela constituição do habitus, o qual termina por engendrar determinados modos de ação e pensamento característicos da condição de classe originária deste agente. Nas palavras de Bourdieu (2013, p. 125), o habitus: "representa a inércia do grupo, depositada em cada organismo sob a forma de esquemas de percepção, apreciação e ação que tendem, com mais firmeza do que todas as normas explícitas (...) a assegurar a conformidade das práticas para 
além das gerações". A partir do conceito de habitus, Bourdieu elaborou uma teoria da ação que permite identificar um conjunto de disposições similares, segundo as condições de origem social dos agentes (habitus de classe). Como explicar, porém, práticas culturais distintivas em meio a um grupo de agentes que possuem trajetórias de socialização familiar e escolares parecidas?

A intelectualização das práticas de alguns alunos pode expressar a existência de um projeto formativo pessoal, que se manifesta na adoção de atitudes simbolicamente associadas à figura do estudante comprometido com seu processo formativo. $\mathrm{O}$ engajamento intelectual, fruto da tentativa de distinguirem-se no meio acadêmico, os levariam a selecionar determinadas práticas e objetos culturais capazes de indicar sua adesão a um universo cultural legitimado:

aspirantes intelectuais, eles esforçam-se para viver essa relação segundo os modelos da classe intelectual, reinterpretados pela lógica de sua condição. Afirmando-se, (...) como sujeito de um livre arbítrio cultural, o estudante frequenta o cineclube, compra discos e toca-discos, decora seu quarto com reproduções, descobre a vanguarda literária ou cinematográfica. (BOURDIEU, 2014, p.60)

A inserção no meio universitário e o contato com os conteúdos científicos e professores especializados podem ter contribuído com a formação dos alunos de modo a tornálos mais inclinados a aquisição de uma cultura diferenciada. Para Bourdieu (2014, p.62), a eficácia da ação escolar reside justamente na capacidade dos professores em fomentar nos discentes determinadas aspirações intelectuais e necessidades de consumo culto. A influência docente, seja por meio "das alusões laudatórias ou dos silenciamentos depreciativos", torna-se ainda mais eficaz na sugestão de práticas dos estudantes, quando estes enxergam na figura do professor o exemplo da intelectualidade que aspiram para si.

O reconhecimento do valor da universidade e de seus saberes ilustra a adesão dos alunos a um universo cultural distintivo, revelador da sua "boa vontade cultural". Tal comportamento se faz presente entre as camadas sociais que não são portadoras de um elevado capital global (econômico, social e cultural) e que avistam no acesso à cultura uma forma de sustentar seu projeto de ascensão no interior da estrutura social. Os portadores da boa vontade cultural reconhecem a cultura legítima e demonstram esforço por tomá-la para si, por meio do investimento em bens e práticas culturais de caráter instrutivo.

Para além de compreender os registros distintivos dos alunos da UNIFESP como resultado da influência do meio acadêmico e da posse da boa vontade cultural por parte dos mesmos, é importante não deixar de considerar que as respostas indicadas também podem ser entendidas como a manifestação dos efeitos da situação de pesquisa. O respondente, na 
condição de investigado, pode oferecer retornos que dissimulam suas práticas reais, na tentativa de legitimar suas ações. Portanto, as respostas distintivas podem simplesmente revelar a capacidade de identificação dos respondentes das obras e práticas reconhecidas, mas que na realidade não pertencem ao seu universo de conhecimento (BOURDIEU, 2007) ${ }^{17}$.

O esforço por dissimular suas práticas efetivas, associado à falta de um conhecimento mais amplo a respeito das práticas culturais legitimadas, fez com que alguns alunos fossem incapazes de demonstrar uma certa coerência na descrição de suas preferências culturais declaradas ao longo da investigação. Assim, foram identificados paradoxos como um ouvinte de MPB que se identificou como leitor da revista AnaMaria; o leitor do jornal Le Monde Diplomatique que indicou o forró como seu estilo musical preferido e o aluno que tem o Louvre como seu museu favorito, mas que não se recorda do nome do último filme visto no cinema. De acordo com Bourdieu (2003b), tais disparates exemplificam a posse de uma formação cultural lacunar e descontínua, adquirida de modo fortuito, além de representar um agente que não possui o conhecimento prático dos sistemas de classificação que definem as condutas distintivas.

Contudo, nem todos os respondentes foram incoerentes em seus registros. A partir da observação detalhada das respostas, foi possível visualizar práticas regularmente diferenciadas, que demonstraram maior familiaridade de alguns com uma vivência cultural socialmente valorizada. Porém, o esforço de distinção entre alunos, cuja origem social remete às camadas sociais menos privilegiadas, pode ser entendido como a realização de escolhas tendencialmente opostas a dos grupos que lhes são mais próximos no espaço social. Entendido por Bourdieu (2007) como um campo de lutas, o espaço social abriga disputas entre grupos que implementam ações voltadas para a manutenção ou progressão de suas posições na estrutura social. Há um esforço constante pelo alcance de localidades mais vantajosas em relação às outras classes que, simultaneamente, disputam pelo mesmo objetivo. Trata-se de uma disputa cujo intuito é justamente a manutenção das distâncias entre os diferentes grupos sociais, uma vez que a posição ocupada pelos agentes possui um caráter relacional em frente aos demais.

Para Bourdieu (2007), o conflito entre as classes sociais é velado e envolve a participação do agente em um jogo social do qual o mesmo não possui consciência de estar envolvido. Porém, sua capacidade de disputa resulta da posse de um senso prático, historicamente definido e adquirido durante seu processo de socialização. Trata-se do habitus

\footnotetext{
${ }^{17}$ Um exemplo desta situação ocorreu quando um respondente, acreditando ter indicado o nome do seu jornal mais lido, registrou o nome da revista Carta Capital em seu lugar.
} 
como sentido de jogo, cuja estrutura objetiva do espaço social foi incorporada como estrutura mental, levando o agente a conhecer suas regras e a disputá-lo sem que se veja na condição de um competidor.

Entre os respondentes da UNIFESP, a partir da observação de suas práticas culturais, é possível identificar grupos distintos de jogadores: uns dotados de maior senso prático e outros com menor sentido de jogo. Tais variações decorrem da multiplicidade do habitus, uma vez que as disposições adquiridas variam de acordo com o volume de capitais detidos pelo agente e que lhes oferece uma maior ou menor capacidade de conhecimento das regras do jogo e, consequentemente, de adaptação às suas demandas.

\subsection{A FORÇA DOS CONDICIONAMENTOS SOCIAIS: O ABANDONO DO DESEJADO E A ADEQUAÇÃO AO QUE É POSSÍVEL}

A investigação a respeito do processo de escolha profissional vivenciado pelos respondentes da UNIFESP indicou que houve praticamente uma condição de equilíbrio entre os que tinham o curso de Pedagogia como primeira opção formativa (27/52) e aqueles que desejavam inicialmente frequentar outra graduação (25/52). Entre estes últimos os cursos desejados eram: Administração (2 indicações), Arquitetura, Ciências Sociais (2 indicações), Direito (2 indicações), Enfermagem (2 indicações), Engenharia Mecânica, Gastronomia, História (2 indicações), Letras (3 indicações), Licenciatura em Artes Visuais (2 indicações), Licenciatura em Ciências, Medicina, Psicologia e Terapia Ocupacional ${ }^{18}$.

As justificativas utilizadas pelos estudantes para explicar a mudança de orientação profissional ocorrida foram fundamentadas sob três grandes argumentos: a) condição financeira; b) reprovação no vestibular para a profissão desejada e c) maior identificação com o curso de Pedagogia ${ }^{19}$. Os dois primeiros argumentos são indicativos do modo como os condicionamentos econômicos e culturais terminaram por encaminhar estes alunos ao curso de Pedagogia. Entre os que destacaram as limitações financeiras $(9 / 25)$, foi possível observar que para muitos os cursos inicialmente desejados só poderiam ser frequentados se os alunos fossem aprovados em alguma universidade pública, visto os mesmos não teriam condições de pagar o

\footnotetext{
${ }^{18}$ Três respondentes deixaram de indicar os nomes dos cursos inicialmente pretendidos.

${ }^{19}$ Os três agrupamentos de justificativas para a mudança da decisão profissional abrangeram vinte dos vinte e cinco respondentes que não tinham o curso de pedagogia como primeira opção formativa. Dos cinco alunos restantes, três não apresentaram nenhuma explicação para a mudança ocorrida, enquanto outros dois alegaram influência familiar, mas sem detalhar como esta ação se deu.
} 
valor das mensalidades cobrado pelas instituições privadas, tal como ilustra o relato a seguir: "Apenas o fato de ingressar em uma universidade pública, por não ter condições de bancar uma particular de Medicina e não ter conseguido ingressar em uma pública [sic].”. Alguns alunos, porém, chegaram a iniciar os cursos pretendidos, mas a possibilidade de frequentar uma universidade gratuita os levou a decidir pela mudança de rumo profissional: "Comecei a cursar Administração em uma faculdade particular, quando fui chamada pelo SISU para cursar Pedagogia, me matriculei”. A partir da leitura dos relatos, foi possível constatar que para os alunos premidos por suas condições financeiras, o fato de ingressar em uma universidade pública termina por servir como a principal justificativa para a mudança dos rumos de sua formação profissional, sendo este argumento utilizado de modo recorrente pelos estudantes investigados. Ao mesmo tempo, cursos que exigem do candidato dedicação exclusiva foram descartados por aqueles que precisam dividir seu tempo entre trabalho e estudo: "O curso que desejava (terapia ocupacional) era em período integral, sendo que preciso trabalhar para me manter, seria impossível [sic]”. A condição financeira também guiou a escolha da formação profissional dos respondentes, ao ponderarem no momento da sua decisão por um curso que, na opinião deles, traria maiores oportunidades profissionais, tal como exemplifica o relato deste aluno que trocou o curso de Letras por Pedagogia devido à "Amplitude do mercado de trabalho".

Para estes alunos, porém, o ingresso nas universidades públicas não seria possível em cursos que compreendem uma seletividade mais acirrada. Assim, as dificuldades para conquistar a aprovação no curso desejado pertencem ao segundo grupo de explicações para a mudança do rumo profissional experimentada por estes estudantes (5/25). A justificativa envolvendo a classificação insuficiente no vestibular abarcou os alunos que desejaram cursos com maior nota de corte no sistema de seleção unificado para as vagas da UNIFESP, disponíveis no campus de Guarulhos, principalmente nos cursos de história e letras ${ }^{20}$ :

“Eu sempre quis ser professora. Como minha nota não daria para passar na primeira chamada no curso de História, mudei a opção para a Pedagogia, pois sabia da importância do curso para aqueles que pretendem lecionar.”;

“Ao prestar o vestibular da Unifesp em 2009, por apenas 2 vagas não consegui entrar no curso de letras, embora fosse possível transferir a partir do $2^{\circ}$ semestre preferi continuar em pedagogia, pois me identifiquei com o curso e ainda estava dentro da área de atuação pretendida que é a docência”.

\footnotetext{
${ }^{20}$ Entre os cinco estudantes que explicaram seu ingresso no curso de pedagogia pelo fato de não terem obtido nota superior no ENEM, somente um tentou um curso de graduação inexistente no campus de Guarulhos da UNIFESP, sendo seu principal objetivo o ingresso no curso de jornalismo.
} 
Estes depoimentos permitiram perceber que, apesar do curso de Pedagogia se constituir como uma segunda opção, os alunos realizaram para esta escolha um movimento de busca por uma formação que tivesse algum tipo de proximidade com o curso inicialmente desejado, nos casos aqui exemplificados, a possibilidade de adquirir o título de licenciado.

A tentativa de identificar uma certa vizinhança entre a escolha inicial e o curso de Pedagogia também levou os respondentes a estabelecerem relações entre o curso e algumas de suas características pessoais, sendo este o terceiro conjunto de justificativas verificado (6/25), tal como exemplifica o relato deste aluno que tinha o curso de ciências sociais como sua primeira opção: "Desde meus 18 atuei como voluntário em movimentos sociais, um deles voltado à não-violência e ativismo comunitário, outro para cursinhos populares e outro ainda de luta por moradia. Desde então passei a ser um ativista da área de educação, sempre com preocupações epistemológicas.” A formação precedente relacionada com a área e o fato de já trabalhar no âmbito da educação também foram apresentados como argumentos para o interesse pelo curso de Pedagogia, reforçando a ideia da existência de uma identidade pregressa do aluno com o curso: "Já estar na área da educação e ter a oportunidade de estudar em uma universidade pública". Por fim, as demais justificativas para a mudança de formação profissional assinalaram a percepção por parte do aluno de possuir uma afinidade maior em relação à sua segunda opção formativa:

“Ao cursar Enfermagem percebi que não queria seguir a profissão...”;

“Honestamente, estava confusa. Minha primeira opção foi Direito por ter realizado o curso técnico em Administração e neste, minhas preferências eram relacionadas à área jurídica. Mas não estava certa do que queria, além de não combinar com meu perfil." $e$

"Senti que poderia ajudar mais as pessoas fazendo pedagogia"21.

Após o esforço de conhecer os motivos que levaram parte dos alunos a trocar o curso inicialmente desejado pela graduação em Pedagogia, interessou investigar as razões que incentivaram os respondentes a frequentarem esta graduação, independentemente do fato do curso ser a primeira ou segunda opção formativa. Dentre as respostas obtidas foi possível estabelecer três categorizações: a) identidade pessoal com a profissão; b) valorização da função social do pedagogo e c) condicionamentos da realidade objetiva ${ }^{22}$.

\footnotetext{
${ }^{21}$ Neste caso, a primeira opção do respondente era o curso de licenciatura em artes visuais.

22 Dos 51 respondentes, um não respondeu à pergunta, enquanto outro não teve sua resposta enquadrada em nenhuma das três categorias criadas. No caso deste último, a escolha da Pedagogia se deu de modo ocasional, sem haver uma justificativa clara para esta decisão: "A princípio caí de para-quedas, mas hoje gosto muito do curso, ele é abrangente quanto a educação, além da formação pessoal que também é enriquecedora [sic]”.
} 
$\mathrm{Na}$ categoria mais recorrente de razões para a frequência ao curso de Pedagogia, destacaram-se as manifestações que expressavam o interesse pessoal dos respondentes pela profissão (30/51). Este interesse foi demonstrado por meio de respostas que declaravam a identificação com a área, a afinidade pelo trabalho com crianças e a expectativa pelo exercício da docência: "Me identifico com a profissão, gosto de crianças”; “(...) sempre tive bons professores no ensino fundamental, isso me fez desejar ensinar”, sendo a frequência ao curso de pedagogia apresentada como a realização de um grande ideal: "Posso dizer que foi a vontade de realizar um sonho da juventude”. As vivências anteriores ao início do curso, seja por meio de experiências profissionais ou durante a formação em outra licenciatura, também foram apontadas como produtoras de interesse pessoal dos respondentes pela graduação em pedagogia:

"Minha relação com a escola pública na qual estudei (gostaria de entender o porquê de alunos com tanto potencial sequer terminarem a educação básica e como reverter ou amenizar isso) e alguns trabalhos voluntários que fiz que me instigaram a cursar[sic].”;

"Ao desistir do curso de Enfermagem, comecei a trabalhar, voluntariamente, em uma escola conveniada a prefeitura da SBC, para conseguir experiência para realizar um intercâmbio cultural denominado Au Pair. Gostei muito do ambiente escolar e da educação infantil. Desisti do intercâmbio e optei por iniciar o curso de pedagogia [sic].”e

“Meu interesse aumentou durante o curso anterior."23

Além do interesse e da afinidade pessoal dos alunos pelo curso, outros respondentes fundamentaram sua escolha por identificarem no meio educativo um instrumento de transformação social (12/51): "Crença na educação como mecanismo de mudança social e cultural." Neste sentido, os respondentes justificam sua escolha profissional pelo valor e reconhecimento que atribuem ao trabalho docente:

“Por enxergar a importância de um educador na sociedade." $e$

"Sempre admirei o papel da pedagoga assim como acredito ser esta uma profissão de tamanha importância social.”

Entre os alunos que destacaram a função social da profissão, existe aqueles que representam o educador como alguém que intercede pelo próximo, desempenhando um trabalho de desenvolvimento e cooperação social, que termina por aproximar em muito a ação docente do trabalho religioso e altruísta, sendo esta uma das motivações para a escolha do curso:

\footnotetext{
${ }^{23}$ Esta aluna concluiu o curso de Letras antes de iniciar a formação em Pedagogia.
} 
“Projeto no terceiro setor - cristão.”;

"A necessidade de ajudar as pessoas. Então, entendendo a educação como a solução para muitos problemas achei que o curso de pedagogia seria uma caminho eficiente para intervir em problemas da sociedade.” $e$

"Sempre trabalhei com crianças e amo a obra social, então achei que era uma ferramenta importante."

A crença nas possibilidades reais de promoção da mudança é tamanha que a escolha da Pedagogia foi, para alguns, realmente motivada pelo desejo de transformar, principalmente, a realidade da escola pública:

"Por ter vindo de escola pública e ter conseguido sair dela com vontade de voltar e trabalhar para contribuir em transformá-la." $e$

“A possibilidade de ajudar a mudar a realidade de pelo menos uma escola pública.”.

Por fim, outros alunos manifestaram simplesmente seu desejo de aprofundar seus conhecimentos no âmbito dos temas educacionais:

“Entender ou compreender o que acontece com a educação.” $e$

"Poder entender a Educação de uma maneira mais ampla."

O terceiro agrupamento de respostas que justifica a escolha do curso de Pedagogia abrange os alunos que destacaram as limitações de ordem objetiva como responsáveis pelo encaminhamento dos mesmos à profissão (7/51). A impossibilidade de frequentar a formação inicialmente desejada fez com que estes alunos vislumbrassem na Pedagogia alguma semelhança com seu objetivo formativo inicial: “Aproximação com minha área de interesse.”; “Por ser 'próximo' ao curso que era minha primeira opção.” As restrições financeiras também conduziram alguns alunos ao curso, estando na sua frequência a possibilidade de inserção no ensino superior gratuito:

“A possibilidade de não ter que pagar por ele";

“Oportunidade de estudar em uma universidade pública.”;

“Ter ficado 3 anos sem cursar nenhuma graduação, no quarto ano pós formação de ensino médio, ingressar em uma faculdade particular com bolsa para cursar Biomedicina e de repente me deparar com a oportunidade de estudar em uma universidade federal."

Uma última justificativa de ordem objetiva para a escolha do curso diz respeito ao receio dos respondentes frente ao seu futuro profissional, levando alguns alunos a optarem pela Pedagogia por reconhecerem nela uma formação produtora de maiores chances de atuação 
profissional: "Oportunidade de aprendizado e novas oportunidades no mercado de trabalho." e “Facilidade para conseguir emprego.", lembrando que esta preocupação também se fez presente entre os alunos que trocaram sua primeira opção profissional por esta graduação.

Diante da pergunta: “O que é ser professor?”, foi possível observar que boa parte dos respondentes (27/51) definiu este profissional a partir dos aspectos pedagógicos contidos em seu trabalho. Para este grupo, ser professor envolve os atos de ensinar, mediar, aprender, educar e formar o aluno. A concepção de ensino, por sua vez, oscilou entre as noções de transmissão (“É poder transmitir aquilo que você já sabe."), partilha ("Exercer um ofício; partilhar conhecimento; mediar relações.") e construção do conhecimento ("Ser professor foi uma escolha e como todas que decidimos seguir vem acompanhada de uma grande responsabilidade, já que ela vai muito mais além da compreensão de transmitir conhecimentos, mas sim de construí-los juntamente com outras pessoas.”).

A representação do professor que ensina, divide seu conhecimento e o elabora com seus alunos concorreu neste grupo, com a imagem do professor mediador:

“É ser um mediador do conhecimento que leva a transformações positivas.”;

"Professor é o mediador, aquele que facilita a construção de um saber acumulado pela escola, além de atuar na formação pessoal do indivíduo.” $e$

"Ser mediador de experiências diferenciadas."

Este professor mediador é, ao mesmo tempo, acompanhado da imagem de um aluno que deve aprender de modo ativo e autônomo, cabendo ao docente tomá-lo como o centro do seu trabalho e de suas preocupações:

"Ser professor é contribuir com a educação de qualidade, refletindo sobre suas práticas e colocando o aluno no centro de suas ações, é viver em um mundo de conflitos, em uma escola complexa, é acreditar que os sujeitos são ativos e por isso merecem autonomia e tem o direito de aprenderem [sic].”

A definição de professor entre os investigados que destacaram os aspectos pedagógicos da profissão, também envolveu a compreensão de que seus alunos possuem o direito de aprender: "É proporcionar a todo indivíduo direito a educação [sic]." Para tanto, uma das responsabilidades docentes é justamente voltar-se para o preparo destes estudantes: “Participar ativamente na formação de um indivíduo.”, considerando seus conhecimentos prévios e sua origem social: "Ser professor é refletir sobre suas ações perante os alunos todos os dias, entender o contexto social que o aluno está inserido e partir da bagagem do aluno para desenvolver um trabalho que signifique para você e para ele." Por fim, nas representações 
dos respondentes, emergiu também a concepção de que ser professor envolve a disposição para não só ensinar, mas também aprender com seus alunos e durante o exercício de sua profissão:

“É saber ensinar e aprender" $e$

"É a figura de alguém que ensina e aprende. Que considera seu aluno um sujeito de direitos e também produto e produtor de determinada cultura."

Do mesmo modo que a escolha do curso de Pedagogia foi justificada por alguns discentes em função do papel social identificado nesta profissão, um segundo conjunto de respondentes (14/51) definiu o que é ser professor a partir desta mesma perspectiva. Para este grupo de alunos, ser professor envolve acreditar na educação como instrumento de mudança e assumir a responsabilidade pela sociedade, tendo em vista transformá-la a partir da formação de cidadãos:

"Alguém que acredita na mudança do mundo, apesar de trabalhar para instituições que buscam a manutenção do mundo.”;

“Ser responsável pela sociedade - crianças hoje e adultos amanhã.”;

"Ser professor é ser agente de uma transformação social, é educar e cuidar com caráter indissociável, é educar para transformar.”;

"Contribuir com uma sociedade melhor.";

“Alguém capaz de mudar a realidade que está inserido.” $e$

"É trabalhar com a proposta de ajudar os alunos a se tornarem cidadãos críticos e formadores de conceitos."

Uma pequena parcela de alunos (9/51) explicou a docência, fundamentados na descrição do comportamento docente, sendo este o terceiro e último grupo de respostas. Frente à profissão, as condutas esperadas foram comprometimento, engajamento, responsabilidade e dedicação:

“Uma tarefa muito difícil que exige dedicação e profissionalismo.” e

“Ter compromisso.”

Outros alunos definiram o que é ser professor a partir da relação deste com seus alunos. Nestes casos, os adjetivos empregados foram companheiro, solidário, atencioso e cuidadoso. Por fim, somente dois alunos relacionaram a docência com uma concepção missionária do magistério, definindo-a como sacerdócio e abnegação:

“Um sacerdócio.” e 
"É contribuir para o crescimento do indivíduo nos aspectos: moral, social e cultural. Fazer de sua profissão um ideal de vida, não importando quanto custe da sua própria vida para alcançar seus objetivos.”

Para alguns alunos, esse modo de ser tem relação com o fato do professor "gostar" do seu trabalho, o que o faz até mesmo esquecer das dificuldades que envolvem a profissão: “Um profissional que em meio a tantas diversidades gosta do que faz e por isto tem compromisso com os seus discentes [sic].”

Considerando as perspectivas profissionais dos respondentes após a conclusão do curso, foi possível notar que todos os alunos deram indicativos do desejo de permanência na profissão. A maior parcela (26/51) espera atuar como professor de educação infantil ou ensino fundamental, preferencialmente em escolas públicas. Por outro lado, catorze alunos manifestaram interesse em atuar em outras esferas da área educacional, com exclusão da sala de aula, envolvendo o trabalho em hospitais, organizações não governamentais, empresas privadas, museus ou na área de administração escolar, seja como coordenadores ou diretores, ou ainda na condição de proprietários de suas próprias escolas. Os onze alunos restantes desejam seguir na profissão, seja na condição de professores ou atuando em áreas diversificadas, sem preferência por nenhum dos tipos de atuação.

A prática do estágio, muitas vezes apontada como desencadeadora do desinteresse pelo exercício da profissão, não afetou negativamente as expectativas profissionais destes alunos. Dos cinquenta e um respondentes, todos declararam o desejo de permanecer na área educacional. Somente uma aluna afirmou que a experiência do estágio teve um impacto negativo sobre suas impressões a respeito da profissão: “(...) fiquei desanimada com as condições de trabalho e salário.”, ainda assim, depois de formada sua opção de atuar como docente nas séries iniciais foi mantida.

Entre os alunos que tinham o curso de Pedagogia como sua primeira opção formativa (27/51), a experiência do estágio foi relatada como positiva e incentivadora da permanência na profissão:

“Serviu para que eu tivesse certeza da área em que eu quero trabalhar.”;

"Percebi que há realmente a possibilidade de dar aulas. Me senti muito mais motivada." $e$

"Possibilitou compreender melhor como a educação pública se estrutura, reforçando minha militância por uma educação pública de qualidade.” 
Mesmo entre os alunos que inicialmente não desejavam cursar Pedagogia, o estágio também os levou a compreender a profissão de modo mais entusiasta, gerando até o interesse em atuar na área educacional:

"Trabalhei durante um ano em um Centro de incentivo à leitura, oferecendo oficinas de leitura e artes para as crianças do município de Guarulhos. Com essa experiência pude perceber o quanto as crianças podem aprender por meio de atividades lúdicas que infelizmente, muitas vezes, não acontecem na escola. Por isso, acredito que essa experiência despertou em mim maior interesse em trabalhar com crianças e com educação.";

“Não pretendia continuar o curso até realizar o estágio.” $e$

"Como uma grande parte dos estudantes, eu queria ficar muito na pesquisa. Com os estágios, percebi a necessidade que as redes (estadual e municipal) precisam de professores comprometidos, e sendo assim, acabei mudando o foco e pretendo ficar na sala de aula também (entretanto, não desisti de fazer o mestrado).”

O relato desta última estudante acerca da pesquisa acadêmica revela que grande parte dos alunos possuía o desejo de se dedicarem à pós-graduação. Essa informação foi de fato confirmada quando os alunos foram indagados a respeito da continuidade de seus estudos após a conclusão do curso de Pedagogia. Como resposta, obteve-se que mais da metade dos alunos (27/51) manifestou seu interesse pelos programas de mestrado, enquanto outros catorze alunos desejam cursar a pós-graduação na modalidade lato sensu. Ou seja, um número bastante expressivo de alunos demonstra disposição em permanecer na área, aprofundando seus saberes profissionais, enquanto somente sete alunos desejam frequentar novos cursos de graduação, sendo alguns deles na modalidade licenciatura ${ }^{24}$.

O contato com os dados dos respondentes da UNIFESP, a respeito do processo de escolha profissional e as expectativas de trabalho e estudos após a conclusão do curso, indicam que apesar de inicialmente metade dos alunos não desejarem frequentar a graduação em Pedagogia, no ano de encerramento da formação todos os respondentes manifestavam seu interesse em trabalhar na área educacional, do mesmo modo que um número significativo de alunos relatava a perspectiva de frequentar cursos de pós-graduação em educação.

Em meio aos respondentes que tinham outros cursos em seus horizontes formativos, as justificativas de mudança na definição profissional sugerem a vivência de restrições financeiras e culturais, comuns entre as camadas desfavorecidas. Como consequência das limitações financeiras, destacou-se um processo de escolha guiado pela inviabilidade de

\footnotetext{
${ }^{24}$ Os cursos de graduação que os estudantes querem cursar são: Artes Plásticas, Letras, licenciatura em Artes Visuais e Medicina.
} 
frequentar cursos superiores em universidades particulares e ministrados em turnos integrais, além destes alunos guiarem suas buscas profissionais perseguindo formações que proporcionassem maiores possibilidades de inserção no mercado de trabalho. No âmbito das limitações formativas, a ausência de um capital cultural familiar elevado, bem como a experiência de uma formação escolar pouco distintiva, terminou por levar estes alunos para os cursos menos disputados das universidades públicas. Nestes casos, a decisão final pelo curso de Pedagogia ilustra o modo como o ingresso em uma dada profissão resulta do posicionamento do agente no interior da estrutura social, cuja localização é definida a partir do volume de diferentes capitais (cultural, econômico e social). A posse dos mesmos termina por indicar aos candidatos suas chances objetivas de ingresso na universidade, ainda que de modo inconsciente, fazendo-os entrever certos estudos superiores como tangíveis ou não, definindo assim suas vocações profissionais (BOURDIEU, 2013; 2014).

Quando não totalmente eliminados do acesso ao ensino superior, as classes baixas e médias sofrem as consequências de sua origem social no momento do ingresso na universidade. A escolha compelida por determinados cursos manifesta a desvantagem de posição a qual tais agentes estão submetidos, promovendo uma distribuição desproporcional das classes sociais no interior do ensino superior, tal como foi constatado nos diversos campi da UNIFESP. De acordo com Bourdieu (2014), a hierarquização dos cursos e de seus candidatos ilustra as desigualdades existentes no contexto do sistema universitário, que termina por relegar às classes populares cursos socialmente desvalorizados, dentre os quais incluem-se aqueles voltados para a formação dos profissionais do magistério.

Entre os alunos que substituíram sua primeira opção profisssional pelo curso de Pedagogia, houve aqueles que não expuseram as limitações objetivas como o principal pretexto da mudança, relatando simplesmente a percepção de uma maior identidade pessoal com a graduação em Pedagogia. Esta mesma identificação com a área foi amplamente utilizada como argumento para responder à pergunta sobre as motivações que os levaram à escolha do curso. Para estes alunos, o reconhecimento em si do gosto pela formação escolhida expressa o modo como os condicionamentos primários afetaram suas expectativas profissionais, alimentando aspirações efetivas, ou seja, aquelas que possuem condições de serem realizadas, pelo fato de estarem ajustadas às condições sociais concretas do agente. Assim, membros das classes populares e médias tomam o que é palpável como propósito, enquanto sua vocação profissional evidencia a introjeção de um vir a ser objetivamente determinado que atinge todos aqueles que partilham do pertencimento a uma mesma categoria social (BOURDIEU, 2013). 
A percepção da escolha profissional como decisão vocacionalizada explica o engajamento dos alunos frente às perspectivas de trabalho e formação continuada após o encerramento do curso. Em termos profissionais, boa parte dos alunos não rejeita a possibilidade do exercício do magistério (37/51), enquanto outros alunos (14/51), mesmo sem desejarem a atuação em sala de aula, pretendem permanecer na educação, desempenhando tarefas em instituições educacionais diversificadas tais como hospitais, organizações não governamentais e museus. A revelação do desejo de atuar na docência veio acompanhada do interesse prioritário pelo trabalho em escolas públicas, podendo esta decisão ser compreendida a partir de duas perspectivas. Um primeiro aspecto se relaciona com o perfil econômico destes estudantes, cujo ingresso no quadro do funcionalismo público traria a segurança financeira que os mesmos, dada sua origem e trajetória social, não usufruem. Para estes alunos, apesar das queixas comuns acerca dos baixos salários pagos aos professores, a obtenção do título de licenciado representa um avanço no que se refere à sua condição socioeconômica original. $\mathrm{O}$ segundo aspecto pode ter relação com o comprometimento social demonstrado por parte dos respondentes ao longo da pesquisa. Entre estes alunos, a escolha do curso de Pedagogia e suas representações a respeito do que é ser professor envolvem a compreensão da educação como instrumento de transformação da sociedade, sendo a escola pública idealizada pelos mesmos como um espaço privilegiado para a implementação destas mudanças.

Valle (2006), ao pesquisar os determinantes da escolha pela carreira docente entre professores das séries iniciais, identificou o mesmo tipo de preocupação entre seus investigados e sugeriu que o encaminhamento para o magistério reside, para alguns, no reconhecimento da função social vislumbrada neste trabalho. Para estas pessoas, o magistério é compreendido como promotor do bem comum, enquanto o professor é tomado como alguém que se responsabiliza pela formação para a cidadania e, consequentemente, para a promoção da mudança social. Nas palavras da autora, "o mito do progresso coletivo confunde-se com o projeto e as ambições individuais" (p.185), ao mesmo tempo que atribui a quem escolheu a profissão uma recompensa simbólica, que a remuneração financeira não proporciona aos seus trabalhadores. A autora emprega a designação "ator social”, formulada por Tardif, para definir o professor cuja identidade profissional reside principalmente na crença de sua atuação como um agente de mudança. Discurso evocado no Brasil desde os anos de 1980, tendo em vista a democratização da educação, Tardif (1998 apud VALLE, 2006) afirma que a concepção do professor como agente de transformação social torna-se comum entre os povos marcados por desigualdades econômicas e culturais, tal como exemplifica a publicação do Projeto Regional 
de Educação para a América Latina e o Caribe, vinculada ao escritório da UNESCO (Organização das Nações Unidas para a Educação, a Ciência e a Cultura), que defende o protagonismo docente na mudança educacional e, consequentemente, social nestas localidades:

\begin{abstract}
A ideia do docente individual, fechado na classe, à margem da responsabilidade social da educação e da escola diante das famílias e das comunidades, está em crise, como também está a clássica divisão entre os que pensam e os que agem, entre os que planejam e os que executam.

(...)

A primeira força associa-se à busca de um sentido renovado da profissão docente, que assegure que os professores tenham capacidades para o exercício profissional, no quadro de uma participação social democrática, com plenas competências para intervir na tomada de decisões, na definição de políticas educacionais, com visão para vincular seu trabalho com o desenvolvimento local e comunitário, sem perder de vista o contexto social mais geral. (CAMPOS, 2005, p. 10 e 22)
\end{abstract}

A função social do professor, destacada entre os respondentes tanto para explicar a mudança de sua opção formativa inicial para a Pedagogia, quanto para justificar a escolha do curso, também pode ter relação com a prática do estágio realizada na UNIFESP. Denominada residência pedagógica, a proposta de estágio implementada envolve uma parceria entre a faculdade e a Secretaria Municipal de Educação de Guarulhos. Assim, a residência pedagógica é prioritariamente realizada no interior de escolas públicas, o que termina por sensibilizar os alunos para a realidade destas instituições. Posteriormente, as vivências do estágio são aproveitadas pelos alunos para a elaboração do trabalho de conclusão do curso (TCC).

De caráter obrigatório, o TCC tem por objetivo aproximar os alunos da prática de pesquisa, desenvolvendo a capacidade de refletir teoricamente a realidade educacional e produzir novos conhecimentos de cunho acadêmico, tal como explica o projeto político pedagógico do curso. O ingresso, durante a graduação, na prática da pesquisa pode ser responsável pelo fato de parte significativa dos respondentes declarar a expectativa de continuidade dos estudos por meio da frequência a cursos de pós-graduação, com destaque para a formação stricto sensu. Por outro lado, o desejo de seguir a carreira acadêmica pode ser interpretado como a manifestação da "boa vontade cultural", tal como Bourdieu (2014) identificou entre os estudantes dos meios sociais desfavorecidos, que buscam nos processos de aperfeiçoamento formativo a compensação das desvantagens decorrentes de sua origem social. Entre os indivíduos originários das camadas menos favorecidas, as instituições educativas apresentam-se como as principais vias de acesso à cultura, satisfazendo o desejo de ascensão pela escola nas classes inferiores e médias. Essa ascensão presumida pela possibilidade da docência no ensino superior elevaria as chances de promoção social destes alunos, dada à estratificação do sistema educacional em níveis de ensino caracterizados por diferenças de prestígio, salário e condições de trabalho (VALLE, 2006). Do mesmo modo que os alunos 
evitaram profissões de inserção profissional e ganhos financeiros entendidos como incertos, além de vislumbrarem na docência em escolas públicas seu objetivo profissional, a procura por cursos de pós-graduação pode ser interpretada como uma estratégia de investimento escolar, tendo em vista a melhora da posição ocupada pelos mesmos no interior do espaço social (BOURDIEU, 2013) $)^{25}$.

Em termos da investigação a respeito do sentido atribuído à docência, diferente do resultado obtido por Almeida (1986, p. 143) em estudo realizado a partir da análise das redações elaboradas durante concurso para professores de $2^{\circ}$ grau em Minas Gerais, cujos candidatos omitiram a tarefa de ensinar dos atributos docentes, para a maior parte dos respondentes da UNIFESP (27/51) ser professor envolve as dimensões pedagógicas de ensinar, educar, formar, mediar e aprender. Esse dado pode ser interpretado de forma bastante otimista, pois, longe dos professores mineiros que defendiam a tese: "ninguém ensina nada a ninguém”, os licenciandos em estudo defendem o ensino como atividade central do trabalho docente. Seja por meio da transmissão, construção ou mediação, o professor é representado como alguém que lida com o conhecimento e tem por meta a promoção da formação cultural de seus alunos, possuindo estes últimos o direito de aprendizagem autônoma e ativa, além de seus saberes prévios serem tomados como ponto de partida do processo formativo. O professor também não é tomado como um profissional pronto, mas como alguém em constante processo de formação e aprendizagem, fruto de sua prática profissional cotidiana e da convivência com seus alunos. Essa concepção da docência, porém, não é compartilhada por todos os alunos investigados.

Enquanto um segundo grupo de respostas definiu o que é ser professor associando a ação educativa ao processo de mudança social (14/51), tal como discutido anteriormente, uma pequena parcela de alunos (9/51) explicou a docência fundamentada na descrição do comportamento docente. Frente à profissão, as condutas esperadas foram comprometimento, engajamento, responsabilidade e dedicação. Auad e Novaes (2008, p. 167), a partir de estudo sobre o perfil dos alunos da primeira turma de pedagogia da UNIFESP, indicaram que a avaliação dos mesmos em relação ao sistema educacional brasileiro não foi positiva, uma vez que a caracterização empregada pelos mesmos foi "péssima, seguida de ruim e precária". Foram citados, entre os problemas apontados pelos alunos como responsáveis pela situação da

\footnotetext{
${ }^{25}$ Livia Lara da Cruz, em sua tese de doutorado defendida em 2013 e intitulada Ascensão pelo estudo ou estagnação qualificada? Os sentidos da experiência do projeto Bolsa Mestrado para os professores da rede estadual de São Paulo (2004-2009), discute o processo decisório de professores da rede pública em cursar o mestrado, tendo em vista a ampliação de suas recompensas materiais e simbólicas, por meio da continuidade de seus estudos. Entre as suas conclusões a pesquisadora identificou que o encerramento do mestrado ofereceu aos professores a obtenção de capital simbólico, além de ganhos econômicos e de capital cultural.
} 
educação, a baixa qualidade em primeiro lugar, seguido pelo desinteresse e desmotivação dos docentes. Essa percepção dos alunos a respeito da responsabilidade dos professores sobre a qualidade da educação pode ter relação, de certa forma, com o modo como parte dos respondentes aqui investigados definiram a docência. Mesmo havendo a ocorrência da definição da profissão a partir da perspectiva do cuidado, da abnegação e do sacerdócio, esse ideário só se fez presente entre três alunos, sendo importante destacar que para praticamente a totalidade dos participantes da pesquisa a profissão docente é entendida mais como uma atividade de ensino que requer responsabilidade profissional, do que um trabalho compreendido a partir de uma visão romântica e missionária.

O estudo acerca do perfil dos respondentes da UNIFESP permitiu identificar que neste grupo há uma significativa diversidade racial. Essa constatação deve-se, em parte, ao fato da instituição reservar em seu processo seletivo $10 \%$ das vagas de ingresso, em cada um de seus cursos, para candidatos autodeclarados pretos, pardos ou indígenas. Porém, o número de negros e indígenas presentes em meio aos estudantes investigados é superior à soma dos beneficiados pelo sistema de cotas, sendo esta uma particularidade do grupo em questão.

Importa destacar também que o campus de Guarulhos, onde o curso de Pedagogia da UNIFESP está sediado, recebeu um perfil de alunado diferenciado em relação aos demais campi dessa universidade. Trata-se do ingresso de alunos socialmente menos privilegiados que os alunos de ciências exatas e biológicas, sendo os mesmos formados em escolas públicas, além de pertencerem a famílias com níveis de renda mais baixos, sendo, ainda, a composição racial do campus mais diversificada, possuindo estas mesmas características o alunado do curso de Pedagogia aqui investigado. Não deve ser desprezado o fato desse campus ter como propósito a formação na área de humanidades e, principalmente, oferecer cursos de licenciatura, os quais terminaram por atrair principalmente um alunado portador de uma condição social menos favorecida em termos econômicos e formativos.

No que se refere às práticas culturais observou-se, de modo geral, o empobrecimento das mesmas, seja pela frequência de realização; pelo tipo de atividade desempenhada e por seus conteúdos. No caso desses respondentes, além da origem social marcada por famílias portadoras de baixo capital cultural e econômico, ao mesmo tempo que seus percursos escolares foram concluídos principalmente em escolas públicas, há ainda que se considerar o fato da localização 
de moradia dos mesmos ser pouco favorecida em termos da disponibilidade de equipamentos culturais. Não se deve desconsiderar, porém, a demonstração por parte de alguns alunos de um comportamento cultural distintivo, o qual emergiu entre os respondentes que cursaram o ensino médio no período matutino, sem que tenham passado pela necessidade de conciliar trabalho e estudo. Conjuntamente, foi ponderado o efeito da universidade sobre a formação dos mesmos, tal como atestaram Setton (1989) e Cruz (2008), aliado à posse da boa vontade cultural, que se manifestou pelo reconhecimento e valorização da cultura dominante presentes entre os alunos investigados.

Em termos de escolha profissional notou-se que metade do grupo de respondentes ingressou no curso de Pedagogia motivados por restrições financeiras e culturais, esta última vinculada à reprovação no vestibular para o curso desejado. Entre as razões para a frequência ao curso de pedagogia novamente os condicionamentos da realidade objetiva foram mencionados, bem como a existência da identidade pessoal dos mesmos com a profissão, além da valorização da função social do pedagogo. Este último aspecto foi novamente retomado pelos respondentes ao apresentarem suas representações acerca da imagem docente, ao lado do destaque dado pelos mesmos aos aspectos instrucionais da profissão.

Quanto aos planos formativos e profissionais verificou-se, mesmo entre os que tinham no curso sua segunda opção formativa, uma significativa adesão ao curso já que os mesmos desejavam atuar na área, principalmente como docentes, além de nutrirem a expectativa de continuidade dos estudos no âmbito da pós-graduação. 


\section{A DIVERSIDADE NO INTERIOR DE UM GRUPO: VARIAÇÕES SOCIOECONÔMICAS, CULTURAIS E DE REPRESENTAÇÃo - O CASO DA PUC/SP}

\subsection{UMA INSTITUIÇÃO, DOIS PERFIS DE ALUNADO}

Conforme observado na Tabela 4.1, a caracterização geral dos respondentes ${ }^{1}$ vinculados à Pontifícia Universidade Católica de São Paulo (PUC/SP) permite identificá-los como um grupo composto predominantemente por mulheres, brancas, solteiras e sem filhos. A faixa etária mais representativa variou dos vinte aos vinte e cinco anos de idade e, considerando a duração mínima do curso a ser concluído em quatro anos, pode-se supor que os mesmos ingressaram na universidade com uma idade inicial de dezessete a vinte e dois anos.

Tabela 4.1 - Distribuição dos respondentes da PUC/SP segundo as variáveis sexo, idade, raça, estado civil e número de filhos.

\begin{tabular}{lll}
\hline Variáveis & Categorias & $\mathbf{n}$ \\
\hline Sexo & Feminino & 24 \\
Total & Masculino & 3 \\
& & 27 \\
Faixa etária & 20 a 25 & 20 \\
& 26 a 30 & 3 \\
Total & 31 ou mais & 4 \\
& & 27 \\
Raça & Branco & 20 \\
& Pardo & 2 \\
& Preto & 4 \\
Total & Amarelo & 1 \\
& & 27 \\
Estado conjugal & Casada & 3 \\
& Solteira & 22 \\
& Separado & 2 \\
Total & & 27 \\
Filhos & Sim & 4 \\
Total & Não & 23 \\
& & 27 \\
\hline
\end{tabular}

\footnotetext{
${ }^{1}$ Nesta instituição contamos inicialmente com a participação de 27 respondentes. Porém, a contribuição total foi de 25 participantes, visto que dois estudantes deixaram de responder o questionário antes de finalizar o mesmo.
} 
Os dados a respeito da trajetória escolar (Tabela 4.2) indicam que estes alunos frequentaram principalmente as instituições de ensino particulares paulistas, tanto no ensino fundamental quanto no ensino médio. Este último foi cursado majoritariamente na modalidade regular e no período diurno, informação compatível com o fato do trabalho no ensino médio não ter se constituído como uma prática comum para parte significativa deste grupo.

\section{Tabela 4.2 - Distribuição dos respondentes da PUC/SP segundo a trajetória escolar e trabalho no ensino médio.}

\begin{tabular}{|c|c|c|}
\hline Variáveis & Categorias & $\mathbf{n}$ \\
\hline Ensino Fundamental & $\begin{array}{l}\text { Privado } \\
\text { Público } \\
\text { Público/Privado }\end{array}$ & $\begin{array}{l}20 \\
5 \\
2 \\
27\end{array}$ \\
\hline Ensino Médio & $\begin{array}{l}\text { Privado } \\
\text { Público } \\
\text { Público/Privado }\end{array}$ & $\begin{array}{l}18 \\
5 \\
4 \\
27\end{array}$ \\
\hline $\begin{array}{l}\text { Local de conclusão do Ensino Médio } \\
\text { Total }\end{array}$ & $\mathrm{SP}$ & $\begin{array}{l}27 \\
27\end{array}$ \\
\hline Modalidade do Ensino Médio & $\begin{array}{l}\text { Regular } \\
\text { Normal/magistério } \\
\text { EJA } \\
\text { Técnico profissionalizante }\end{array}$ & $\begin{array}{l}19 \\
4 \\
2 \\
2 \\
27\end{array}$ \\
\hline $\begin{array}{l}\text { Turno do Ensino Médio } \\
\text { Total }\end{array}$ & $\begin{array}{l}\text { Diurno } \\
\text { Noturno }\end{array}$ & $\begin{array}{l}22 \\
5 \\
27\end{array}$ \\
\hline Trabalho no Ensino Médio & $\begin{array}{l}\text { Sim } \\
\text { Não }\end{array}$ & $\begin{array}{l}6 \\
21 \\
27\end{array}$ \\
\hline Jornada de trabalho no Ensino Médio & $\begin{array}{l}\text { Até } 20 \mathrm{~h} / \mathrm{s} \\
\text { De } 21 \text { a } 30 \mathrm{~h} / \mathrm{s} \\
\text { De } 31 \text { a } 40 \mathrm{~h} / \mathrm{s}\end{array}$ & $\begin{array}{l}3 \\
1 \\
2 \\
6\end{array}$ \\
\hline
\end{tabular}

Como visto na Tabela 4.3, dos vinte e sete respondentes, onze passaram por outras graduações antes de seguirem para a formação em Pedagogia. Destes, cinco concluíram os cursos nas áreas de Filosofia (licenciatura e bacharelado), Publicidade e Propaganda, Licenciatura em Música, Odontologia e Teologia. Entre aqueles cuja primeira graduação foi mesmo o curso de Pedagogia (16/27), catorze ingressaram até um ano após a finalização do ensino médio e entre eles, cinco passaram por cursinhos preparatórios para o vestibular pelos períodos de um semestre a um ano (Tabela 4.4). 
Tabela 4.3 - Distribuição dos respondentes da PUC/SP segundo o início de curso de graduação anterior à pedagogia.

\begin{tabular}{lll}
\hline Variáveis & Categorias & $\mathbf{n}$ \\
\hline Iniciou outra graduação & Sim & 11 \\
& Não & 16 \\
Total & & 27 \\
& & \\
Concluiu o curso iniciado & Sim & 5 \\
Total & Não & 6 \\
\hline
\end{tabular}

Tabela 4.4 - Distribuição dos respondentes da PUC/SP em relação ao tempo de permanência no cursinho e intervalo entre a finalização do ensino médio e ingresso no curso de pedagogia como primeira graduação.

\begin{tabular}{lcccc}
\hline $\begin{array}{l}\text { Tempo de ingresso no curso de pedagogia } \\
\text { como primeira graduação, após o ensino } \\
\text { médio }\end{array}$ & \multicolumn{5}{c}{ Permanência cursinho } \\
\hline & Não frequentou & Até 1 sem & 1 sem a 1 ano & 1 a 1,5 ano \\
\hline Menos de um ano & 7 & 3 & 1 & 0 \\
Um ano & 2 & 0 & 1 & 0 \\
Acima de 3 anos & 1 & 0 & 0 & 1 \\
Total & 10 & 3 & 2 & 1 \\
\hline
\end{tabular}

Em termos de formação escolar materna e paterna (Tabela 4.5), identificou-se o nível universitário como o grau de escolaridade mais alto alcançado pelos pais de pouco mais da metade deste grupo de alunos, havendo casos em que os mesmos contam com o título de pósgraduados (5/14, tanto entre os pais como entre as mães). Dentre as ocupações desempenhadas pelos pais, observou-se a predominância das atividades implementadas nas áreas da Arquitetura, Direito, Engenharia, Medicina, entre outras com valor social similar. Em meio às mães, foram citadas profissões como as de professora, socióloga, contadora, enfermeira, além de outros trabalhos que requerem formação universitária. 
Tabela 4.5 - Distribuição dos respondentes da PUC/SP segundo o nível de instrução paterno e materno e ocupação desenvolvida pelos mesmos. ${ }^{2}$

\begin{tabular}{|c|c|c|}
\hline Variáveis & Categorias & $\mathrm{n}$ \\
\hline Instrução pai & $\begin{array}{l}\text { Até Ensino Fundamental } \\
\text { Ensino Médio } \\
\text { Superior ou Pós-graduação }\end{array}$ & $\begin{array}{l}5 \\
7 \\
14 \\
26\end{array}$ \\
\hline Instrução mãe & $\begin{array}{l}\text { Até Ensino Fundamental } \\
\text { Ensino Médio } \\
\text { Superior ou Pós-graduação } \\
\text { Não sei }\end{array}$ & $\begin{array}{l}3 \\
8 \\
14 \\
1 \\
26\end{array}$ \\
\hline Ocupação pai & $\begin{array}{l}\text { Profissional liberal ou atividade profissional com } \\
\text { exigência formativa elevada. } \\
\text { Serviços administrativos, comércio, serviços } \\
\text { técnicos e demais ocupações que exigem } \\
\text { formação escolar mediana. } \\
\text { Trabalho manual, produção de bens e serviços } \\
\text { industriais e atividades profissionais que exigem } \\
\text { baixa exigência formativa. } \\
\text { Outros }^{3}\end{array}$ & $\begin{array}{l}3 \\
2 \\
26\end{array}$ \\
\hline Ocupação mãe & $\begin{array}{l}\text { Profissional liberal ou atividade profissional com } \\
\text { exigência formativa elevada. } \\
\text { Serviços administrativos, comércio, serviços } \\
\text { técnicos e demais ocupações que exigem } \\
\text { formação escolar mediana. } \\
\text { Trabalho manual, produção de bens e serviços } \\
\text { industriais e atividades profissionais que exigem } \\
\text { baixa exigência formativa. } \\
\text { Não sei }\end{array}$ & $\begin{array}{l}7 \\
1 \\
26\end{array}$ \\
\hline
\end{tabular}

Tomando a condição ocupacional dos respondentes (Tabela 4.6), foi identificado um número significativo de alunos que trabalhavam no último ano do curso de graduação (23/26), prevalecendo aqueles que atuavam na área educacional (20/23), em regime parcial de dedicação. Dentre as atividades desenvolvidas, foi possível localizar aqueles que se dedicavam à docência; ao trabalho na administração escolar e ao desenvolvimento de pesquisas no âmbito da iniciação científica. Porém, à época da aplicação do questionário, a maior parcela dos formandos atuava como estagiários, estando parte deles (6/12) inseridos em escolas particulares reconhecidas e elitizadas, tais como o Colégio Dante Alighieri, Colégio São Luís, Colégio Nossa Senhora de Sion, St. Francis College e Chapel School - Escola Maria Imaculada, sendo estas duas últimas, instituições de ensino internacionais. Cabe destacar que as remunerações mais elevadas entre os estagiários foram pagas justamente aos alunos que atuavam nestas instituições; entretanto, para parte deles, o salário recebido não se distanciou dos valores comumente atribuídos aos alunos que desempenhavam este tipo de atividade em instituições

\footnotetext{
${ }^{2}$ Nesta tabela contamos com a participação total de 26 respondentes, após a desistência de um dos investigados.

${ }^{3} \mathrm{O}$ item "Outros" foi aqui utilizado para designar os registros imprecisos realizados pelos respondentes, que impediram a clara identificação da ocupação desempenhada.
} 
não renomadas, estando seus rendimentos situados entre as faixas de um e dois salários mínimos.

Tabela 4.6 - Distribuição dos respondentes PUC/SP quanto à atividade ocupacional, rendimentos e regime de trabalho durante a graduação.

\begin{tabular}{|c|c|c|}
\hline Variáveis & Categorias & $\mathrm{n}$ \\
\hline Ocupação & $\begin{array}{l}\text { Atividades não educacionais: } \\
\text { produtor, bancária e secretária } \\
\text { Docência } \\
\text { Estágio } \\
\text { Iniciação científica } \\
\text { Trabalho administrativo em escola }\end{array}$ & $\begin{array}{l}3 \\
5 \\
12 \\
1 \\
2 \\
23\end{array}$ \\
\hline Rendimentos & $\begin{array}{l}\text { Não tenho rendimentos } \\
\text { Até } 1 \mathrm{~s} . \mathrm{m} . \\
\text { Entre } 1 \text { e } 2 \mathrm{s.m} . \\
\text { Entre } 2 \text { e } 3 \mathrm{s.m} . \\
\text { Entre } 3 \text { e } 5 \mathrm{~s} . \mathrm{m} . \\
\text { Entre } 5 \text { e } 7 \mathrm{s.m} . \\
\text { Entre } 7 \text { a } 10 \mathrm{~s} . \mathrm{m} .\end{array}$ & $\begin{array}{l}1 \\
3 \\
9 \\
4 \\
3 \\
1 \\
2 \\
23\end{array}$ \\
\hline Rendimentos professoras & $\begin{array}{l}\text { Entre } 2 \text { e } 3 \text { s.m. } \\
\text { Entre } 3 \text { e } 5 \text { s.m. } \\
\text { Entre } 5 \text { e } 7 \text { s.m. } \\
\text { Entre } 7 \text { a } 10 \text { s.m. }\end{array}$ & $\begin{array}{l}1 \\
2 \\
1 \\
1 \\
5\end{array}$ \\
\hline Rendimentos estagiárias & $\begin{array}{l}\text { Até } 1 \text { s.m. } \\
\text { Entre } 1 \text { e } 2 \text { s.m. } \\
\text { Entre } 2 \text { e } 3 \text { s.m. } \\
\text { Entre } 7 \text { a } 10 \text { s.m. }\end{array}$ & $\begin{array}{l}1 \\
9 \\
1 \\
1 \\
12\end{array}$ \\
\hline $\begin{array}{l}\text { Regime de trabalho } \\
\text { Total }\end{array}$ & $\begin{array}{l}\text { Parcial } \\
\text { Integral }\end{array}$ & $\begin{array}{l}14 \\
9 \\
23\end{array}$ \\
\hline
\end{tabular}

O exame do rendimento per capita mensal familiar, de modo geral, demonstra que os ganhos predominantes estão situados nas parcelas que variam entre dois e quatro salários mínimos, conforme verificado na Tabela 4.7. Ao mesmo tempo, constatou-se a existência de diferentes níveis de renda, os quais evidenciaram a coexistência de dois subgrupos de alunos detentores de condições financeiras diferenciadas: os que ganham até dois salários mínimos mensais por pessoa e os que estão acima dessa faixa de rendimentos. Desta forma, o corpo de alunos aqui investigado possui características distintas no que se refere ao perfil econômico, extensivas às condições sociais e ao turno de curso da faculdade, conforme será detalhado a seguir. 
Tabela 4.7 - Distribuição dos respondentes PUC/SP quanto à renda familiar mensal per capita.

\begin{tabular}{lll}
\hline Variáveis & Categorias & $\mathbf{n}$ \\
\hline Renda familiar per capita & Até 1 s.m. & 4 \\
& 1 até 2 s.m. & 5 \\
& 2 até 4 s.m. & 12 \\
Total & 4 ou mais s.m. & 5 \\
& & 26 \\
\hline
\end{tabular}

Enquanto os dados de caracterização geral dos respondentes da PUC/SP indicam a composição de um agrupamento de alunos marcado por uma origem social e escolar mais privilegiada, notadamente pela observação da renda familiar per capita, do nível de escolaridade e ocupação dos pais, bem como pela trajetória de formação escolar dos alunos, há, contrariamente, um grupo menor que se distancia significativamente deste primeiro.

A fim de verificar a existência de perfis que se distinguem considerando-se os dois turnos em que o curso é ministrado - matutino e noturno - foi possível constatar, a partir da Tabela 4.8, algumas características que particularizam, principalmente, os alunos do período da noite. Inicialmente, o exame das variáveis sexo, idade, raça, estado civil e número de filhos, indicou haver distinções nos quesitos gênero, raça e filhos. Assim, no período noturno, encontram-se os únicos três homens presentes no grupo de respondentes investigados, bem como a maior parte dos negros e as alunas que já são mães. Os aspectos idade e estado civil não sofreram alterações quando observados a partir da perspectiva do turno, havendo uma distribuição equitativa entre os mesmos.

Tabela 4.8 - Distribuição do gênero, raça e posse de filhos entre os turnos da PUC/SP.

\begin{tabular}{lll}
\hline Variáveis & Categorias & $\mathbf{n}$ \\
\hline Sexo masculino & Diurno & 0 \\
& Noturno & 3 \\
Raça negra & Diurno & 1 \\
& Noturno & 5 \\
Tem filhos & Diurno & 1 \\
& Noturno & 3 \\
\hline
\end{tabular}

Quanto ao quesito trajetória escolar (Tabela 4.9), nota-se mais uma vez que parte dos alunos do período noturno distingue-se dos demais. Entre eles encontram-se todos os alunos do grupo que vivenciaram uma trajetória escolar menos privilegiada, marcada pela frequência a instituições públicas, trabalho concomitante ao período de formação escolar, preparo em cursinhos e uma interrupção maior entre a finalização do ensino médio e início do ensino 
superior, não obstante estejam no período noturno dois alunos dos quatro que cursaram o ensino médio na modalidade normal/magistério, e os dois únicos que concluíram suas formações em escolas técnico profissionais.

Tabela 4.9 - Distribuição da trajetória escolar entre os turnos da PUC/SP.

\begin{tabular}{lll}
\hline Variáveis & Categorias & $\mathbf{n}$ \\
\hline Frequentou ensino fundamental público & Diurno & 0 \\
& Noturno & 5 \\
& & \\
Frequentou ensino médio público & Diurno & 0 \\
& Noturno & 5 \\
Trabalhou no Ensino Médio & Diurno & 0 \\
& Noturno & 6 \\
Frequentou cursinho4 & Diurno & 3 \\
& Noturno & 7 \\
Ocorrência de intervalo entre a finalização do & & \\
ensino médio e início do ensino superior & Diurno & 3 \\
& Noturno & 8 \\
\hline
\end{tabular}

No que se refere ao nível de instrução paterno e materno e as ocupações desempenhadas pelo mesmos (Tabela 4.10), notou-se o predomínio da formação universitária entre as mães de ambos os turnos, frente aos demais níveis de escolaridade; porém, proporcionalmente, há mais mães universitárias no período matutino. Quanto aos pais, novamente verifica-se a predominância da formação universitária (com relação aos níveis médio e fundamental) nos dois períodos, havendo equilíbrio significativo da posse desse nível de instrução considerando-se a divisão entre os turnos. Associadas ao nível de formação, as ocupações desempenhadas pelos progenitores seguem a mesma lógica de distribuição observada nos graus de instrução.

\footnotetext{
${ }^{4}$ A partir das respostas registradas identificou-se que 11 alunos frequentaram cursinhos preparatórios para o vestibular, entretanto, um desses respondentes abandonou o questionário sem que o mesmo fosse concluído. Por este motivo a distribuição da frequência ao cursinho, em relação aos turnos, apresenta agora uma somatória total de apenas 10 participantes.
} 
Tabela 4.10 - Distribuição do nível de instrução e ocupação paterno e materno entre os turnos da PUC/SP.

\begin{tabular}{|c|c|c|c|}
\hline Variáveis & Categorias & Diurno & Noturno \\
\hline \multirow[t]{3}{*}{ Grau de instrução paterno } & Ensino Fundamental & 2 & 3 \\
\hline & Ensino Médio & 2 & 5 \\
\hline & Ensino Superior & 5 & 9 \\
\hline Total & & 9 & 17 \\
\hline \multirow[t]{6}{*}{ Ocupação paterna } & $\begin{array}{l}\text { Profissional liberal ou atividade profissional com } \\
\text { exigência formativa elevada. }\end{array}$ & 5 & 9 \\
\hline & $\begin{array}{l}\text { Serviços administrativos, comércio, serviços } \\
\text { técnicos e demais ocupações que exigem }\end{array}$ & & \\
\hline & formação escolar mediana. & 3 & 4 \\
\hline & $\begin{array}{l}\text { Trabalho manual, produção de bens e serviços } \\
\text { industriais e atividades profissionais que exigem }\end{array}$ & & \\
\hline & baixa exigência formativa. & 1 & 2 \\
\hline & Outros 5 & & 2 \\
\hline Total & & 9 & 17 \\
\hline \multirow[t]{4}{*}{ Grau de instrução materno } & Ensino Fundamental & 1 & 2 \\
\hline & Ensino Médio & 2 & 6 \\
\hline & Ensino Superior & 6 & 8 \\
\hline & Não sei & & 1 \\
\hline Total & & 9 & 17 \\
\hline \multirow[t]{6}{*}{ Ocupação materna } & $\begin{array}{l}\text { Profissional liberal ou atividade profissional com } \\
\text { exigência formativa elevada. }\end{array}$ & 5 & 8 \\
\hline & $\begin{array}{l}\text { Serviços administrativos, comércio, serviços } \\
\text { técnicos e demais ocupações que exigem }\end{array}$ & & \\
\hline & formação escolar mediana. & 2 & 3 \\
\hline & $\begin{array}{l}\text { Trabalho manual, produção de bens e serviços } \\
\text { industriais e atividades profissionais que exigem }\end{array}$ & & \\
\hline & baixa exigência formativa. & 2 & 5 \\
\hline & Não sei & & 1 \\
\hline Total & & 9 & 17 \\
\hline
\end{tabular}

Observando a distribuição da renda familiar mensal per capita entre os turnos (Tabela 4.11), nota-se que no período diurno há maior concentração de rendimentos entre as faixas que estão acima de dois salários mínimos mensais per capita (7/9). No período noturno, a predominância da faixa acima de dois salários mínimos se mantém (10/17), porém há um número significativo de alunos cujas famílias localizam-se nas faixas inferiores de rendimento (abaixo de dois salários mínimos per capita mensal).

Tabela 4.11 - Distribuição da renda familiar per capita entre os respondentes da PUC/SP.

\begin{tabular}{llll}
\hline Variáveis & Categorias & Diurno & Noturno \\
\hline Renda familiar per capita & Até 1 s.m. & 0 & 4 \\
& 1 até 2 s.m. & 2 & 3 \\
& 2 até 4 s.m. & 5 & 7 \\
& 4 ou mais s.m. & 2 & 3 \\
\hline
\end{tabular}

\footnotetext{
${ }^{5} \mathrm{O}$ item "Outros" foi aqui utilizado para designar os registros imprecisos realizados pelos respondentes, que impediram a clara identificação da ocupação desempenhada.
} 
O Gráfico 4.1 ilustra as diferenças existentes entre os rendimentos familiares per capita, considerando-se ambos os turnos. Por meio desta representação, nota-se que, no período noturno, encontram-se todas as famílias, cujos rendimentos estão abaixo de um salário mínimo, enquanto no período diurno, contrariamente, localiza-se a maior parcela das famílias que reúnem as melhores condições financeiras.

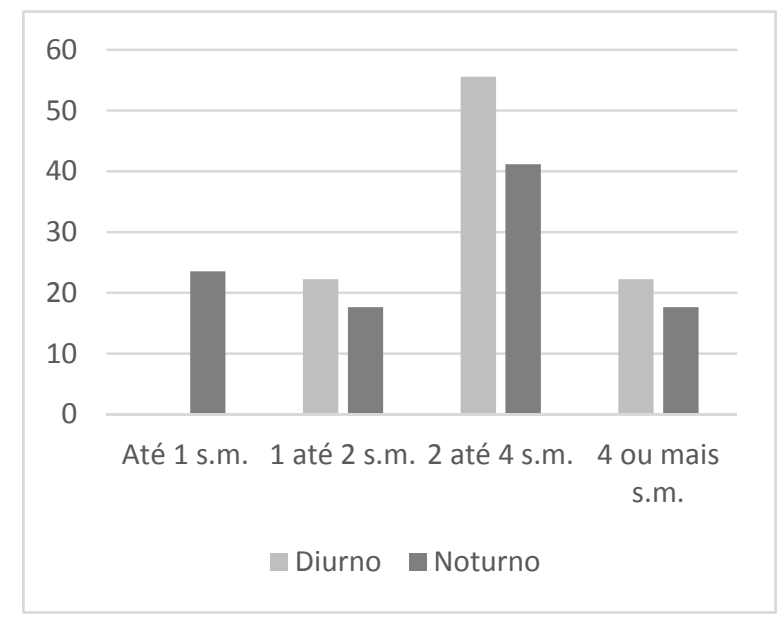

\section{Gráfico 4.1 - Apresentação gráfica da distribuição da renda familiar per capita mensal entre os turnos da PUC/SP.}

A observação da distribuição diferenciada dos rendimentos nos diferentes períodos (Tabela 4.12) é ratificada ao observarmos a repartição entre os turnos dos alunos bolsistas ou que fazem uso dos programas de financiamento estudantil para o custeio de sua formação universitária, tendo lugar justamente no período noturno os seus beneficiários.

Tabela 4.12 - Distribuição de bolsas de estudo ou financiamento estudantil entre os turnos da PUC/SP.

\begin{tabular}{lll}
\hline Variáveis & Categorias & $\mathrm{n}$ \\
\hline Bolsa de estudos ou financiamento estudantil & Diurno & 0 \\
& Noturno & 8 \\
\hline
\end{tabular}

Pode ser verificado na Tabela 5.13 que, entre os bolsistas, aqueles favorecidos pelo PROUNI contaram com auxílios integrais, enquanto outra parte dos estudantes subsidiou sua formação junto ao programa de financiamento do Ministério da Educação (FIES). Houve, ainda, aqueles que foram auxiliados com bolsas institucionais concedidas pela mantenedora da PUC/SP - a Fundação São Paulo - dirigidas aos alunos que comprovaram renda per capita máxima de até três salários mínimos. Para estes alunos, a renda familiar per capita reduzida 
não agiu como impedimento ao ingresso em uma instituição cuja mensalidade estaria fora do seu alcance ${ }^{6}$, visto que a posse de bolsas de estudo oportunizou o ingresso e a permanência dos mesmos nesta universidade.

\section{Tabela 4.13 - Distribuição de bolsa de estudos ou financiamento estudantil entre os respondentes da PUC/SP.

\begin{tabular}{lll}
\hline Variáveis & Categorias & $\mathbf{n}$ \\
\hline \multirow{2}{*}{ Bolsa de estudos ou financiamento estudantil } & PROUNI & 3 \\
& FIES & 2 \\
& Bolsa institucional - & \\
& integral ou parcial & 3 \\
Total & & 8 \\
\hline
\end{tabular}

A partir dos dados apresentados, pode-se afirmar a existência de dois subgrupos com características diversas entre os respondentes aqui investigados. De um lado, temos um grupo mais amplo, composto pelos alunos portadores de uma condição social vantajosa, estando entre eles as famílias portadoras das faixas de renda mais elevadas; com predomínio de pais com formação escolar universitária e dedicados a ocupações profissionais de maior reconhecimento social. A trajetória escolar destes alunos também foi privilegiada, uma vez que frequentaram instituições privadas de ensino, sem a necessidade de conciliar o trabalho ao estudo. Este perfil de estudante termina por se fazer mais presente no período diurno desta instituição. Por outro lado, no período noturno, encontra-se parte dos alunos que usufruem de condições sociais menos favoráveis. Entre eles estão os alunos negros, oriundos de escolas públicas, que trabalharam durante o ensino médio e cujo preparo para o ingresso no ensino superior envolveu a passagem por cursinhos. A renda familiar mensal per capita mais baixa também se faz presente entre algumas famílias de estudantes do período noturno, estando entre eles os cursistas que dependeram de bolsas de estudo ou financiamento estudantil para a sua manutenção no ensino superior. Cabe destacar, porém, que nem todos os alunos do período noturno partilham das mesmas condições sociais desprivilegiadas, havendo, neste mesmo turno, outros estudantes que usufruem de condições sociais semelhantes às observadas entre os respondentes do período matutino.

\footnotetext{
${ }^{6} \mathrm{O}$ valor aproximado da mensalidade do curso, informado pela instituição, é de $\mathrm{R} \$ 1.200,00$.
} 


\subsection{AS PRÁTICAS CULTURAIS E A EXPRESSÃO DO HABITUS DE CLASSE}

A pesquisa em torno do modo como os respondentes da PUC/SP utilizam seu tempo livre (Tabela 4.14) indicou que as atividades frequentemente desenvolvidas por mais da metade dos alunos são: acessar a internet, ouvir música, ler, ver televisão e frequentar parques. Assistir filmes no cinema e viajar, por sua vez, não foram atividades realizadas com frequência por mais da metade dos alunos (11/25), porém, ao se incluir aqueles que as praticaram ocasionalmente, tem-se um contingente de quase quatro em cada cinco alunos que tendem ir ao cinema ou viajar nas suas horas de lazer.

Tabela 4.14 - Atividades mais frequentemente realizadas no tempo livre pelos respondentes da PUC/SP.

\begin{tabular}{|c|c|c|c|c|}
\hline Variáveis & Categorias & $\begin{array}{l}\text { Período } \\
\text { diurno }\end{array}$ & $\begin{array}{l}\text { Período } \\
\text { noturno }\end{array}$ & Total \\
\hline Internet & Frequentemente & 8 & 17 & 25 \\
\hline \multirow[t]{4}{*}{ Ouvir música } & Frequentemente & 5 & 12 & 17 \\
\hline & Ocasionalmente & 2 & 3 & 5 \\
\hline & Raramente & 0 & 2 & 2 \\
\hline & Nunca & 1 & 0 & 1 \\
\hline Total & & 8 & 17 & 25 \\
\hline \multirow[t]{4}{*}{ Leituras } & Frequentemente & 5 & 11 & 16 \\
\hline & Ocasionalmente & 1 & 6 & 7 \\
\hline & Raramente & 2 & 0 & 2 \\
\hline & Nunca & 0 & 0 & 0 \\
\hline Total & & 8 & 17 & 25 \\
\hline \multirow[t]{4}{*}{ Televisão } & Frequentemente & 6 & 9 & 15 \\
\hline & Ocasionalmente & 0 & 3 & 3 \\
\hline & Raramente & 1 & 5 & 6 \\
\hline & Nunca & 1 & 0 & 1 \\
\hline Total & & 8 & 17 & 25 \\
\hline \multirow[t]{5}{*}{ Parques } & Frequentemente & 5 & 8 & 13 \\
\hline & Ocasionalmente & 0 & 7 & 7 \\
\hline & Raramente & 1 & 1 & 2 \\
\hline & Nunca & 1 & 1 & 2 \\
\hline & Não resposta & 1 & & 1 \\
\hline Total & & 8 & 17 & 25 \\
\hline \multirow[t]{4}{*}{ Cinema } & Frequentemente & 4 & 7 & 11 \\
\hline & Ocasionalmente & 2 & 6 & 8 \\
\hline & Raramente & 2 & 4 & 6 \\
\hline & Nunca & 0 & 0 & 0 \\
\hline Total & & 8 & 17 & 25 \\
\hline \multirow[t]{4}{*}{ Viagem } & Frequentemente & 5 & 6 & 11 \\
\hline & Ocasionalmente & 2 & 5 & 7 \\
\hline & Raramente & 1 & 6 & 7 \\
\hline & Nunca & 0 & 0 & 0 \\
\hline Total & & 8 & 17 & 25 \\
\hline
\end{tabular}

A atividade de maior destaque entre os alunos possui relação com o acesso à internet. Todos os participantes da pesquisa, sem exceção, afirmaram utilizá-la frequentemente. A maioria dos acessos (16/25) ocorreu por meio de aparelhos eletrônicos móveis, seguido por 
consultas realizadas nas casas dos estudantes (7/25) e, de forma menos recorrente, a partir do local de trabalho (2/25). Entre estes alunos o uso da internet se dá principalmente para fins de lazer $(9 / 25)$, trocas de email $(7 / 25)$, uso de redes sociais $(5 / 25)$, leitura de notícias $(3 / 25)$ e para objetivos profissionais $(1 / 25)$.

Posteriormente ao uso da internet, a segunda atividade mais desenvolvida pelos alunos durante seu tempo livre envolveu a escuta musical, sendo esta prática igualmente desenvolvida entre os respondentes dos dois turnos (aproximadamente 9/10 escutam frequentemente ou ocasionalmente em ambos os períodos). Entre os gêneros mencionados ${ }^{7}$ foi possível observar, na Tabela 4.15, maior recorrência da música popular brasileira (MPB), com cinco referências, seguida pelo sertanejo que contou com quatro menções. Com duas indicações foram citados: o pagode, o pop, o rock, o samba e o rap. Outros gêneros contaram com apenas uma menção e apontaram a música religiosa (gospel) e estilos musicais associados ao público jovem, tais como o reggae e a música eletrônica.

Tabela 4.15 - Distribuição dos gêneros musicais apreciados pelos respondentes da PUC/SP.

\begin{tabular}{ll}
\hline Gêneros musicais & $\mathbf{n}$ \\
\hline Blues & 1 \\
Eletrônica & 1 \\
Gospel & 1 \\
Hip Hop & 1 \\
Indefinido & 2 \\
MPB & 5 \\
Pagode & 2 \\
Pop & 2 \\
Rap & 1 \\
Reggae & 1 \\
Rock & 2 \\
Samba & 2 \\
Sertanejo & 4 \\
Total & 25 \\
\hline
\end{tabular}

Pesquisas desenvolvidas na área das práticas culturais (BOTELHO; FIORE, 2005; FORJAZ, 1988; JLeiva Cultura \& Esporte, 2014; IBOPE Média, 2013) identificaram que, além da faixa etária dos ouvintes afetar seu gosto musical, os níveis de escolaridade e renda também incidem nas preferências por determinados gêneros. Enquanto os apreciadores da MPB, do samba, do rock e blues revelam possuir maiores níveis de renda e formação escolar, contrariamente, o sertanejo, o pagode e o gospel possuem, como público, ouvintes portadores de menor nível de escolaridade e rendimentos.

No caso dos respondentes da PUC/SP, essa divisão entre os gostos musicais também se fez presente. Utilizando o recorte renda e considerando as faixas situadas acima de quatro

\footnotetext{
${ }^{7}$ Dois respondentes não definiram suas preferências musicais.
} 
salários mínimos per capita, observa-se que os alunos citaram a escuta da MPB, do samba, do blues, do reggae e do rap como seus gêneros musicais preferidos. Estes alunos são majoritariamente oriundos de escolas particulares e são filhos de pais com formação universitária. Por outro lado, nas faixas de renda iguais ou inferiores a um salário mínimo per capita, nota-se novamente a indicação da MPB, além da indicação dos gêneros: pagode, sertanejo, rap e gospel. Neste caso, o nível de instrução familiar predominante é o fundamental e médio, além desses alunos terem cursado sua formação básica em escolas públicas. Assim, os dados indicam que, apesar da MPB contar com citações entre as duas faixas de renda, os demais gêneros obedecem exatamente à divisão de preferência que envolve os diferentes grupos sociais, tal como as pesquisas a respeito das práticas culturais haviam identificado. A correspondência entre a origem social dos alunos e o gosto musical, tal como identificado entre os respondentes da PUC/SP, representa aquilo que Bourdieu (2007) denominou como habitus de classe. De acordo com o autor, o habitus de classe caracteriza um conjunto de agentes situados em condições homogêneas de existência, que os leva a partilhar determinados modos de pensamento e ação. Assim, entre grupos proprietários de um mesmo volume de capital global (social, econômico e cultural), o gosto termina por revelar simbolicamente a posição de classe dos agentes.

No que se refere à prática de leitura (Tabela 4.16), atividade significativamente frequente em ambos os turnos, foi observada a predileção pelos livros, enquanto os alunos manifestaram baixo interesse por periódicos. A leitura de jornais foi a que se mostrou menos frequente, já que doze alunos afirmaram não utilizar essa fonte de informação, enquanto outros nove estudantes declararam pouco recorrer aos mesmos, considerando-se os respondentes de ambos os turnos. Quanto às revistas, estas são utilizadas pelos alunos, porém, de modo muito pouco rotineiro. 
Tabela 4.16 - Frequência da leitura de livros, revistas e jornais entre os respondentes da PUC/SP.

\begin{tabular}{lll}
\hline Variáveis & Categorias & $\mathbf{n}$ \\
\hline Livros & Leio muito & 10 \\
& Leio regularmente & 9 \\
Total & Leio pouco & 6 \\
Revistas & & 25 \\
& Leio muito & 3 \\
& Leio regularmente & 6 \\
& Leio pouco & 13 \\
Total & Não leio & 3 \\
& & 25 \\
Jornais & Leio muito & 2 \\
& Leio regularmente & 2 \\
& Leio pouco & 9 \\
Total & Não leio & 12 \\
\hline
\end{tabular}

Gatti e Barreto (2009), em estudo a respeito das práticas culturais de estudantes universitários dos cursos de licenciatura, identificaram que o público jovem possui uma tendência atual de utilizar predominantemente como fonte de informação a televisão e a internet. No caso dos respondentes da PUC/SP, a assistência à televisão é realmente elevada, constituindo-se como a terceira atividade mais praticada durante o tempo livre. Porém, os programas preferidos dos alunos não são aqueles capazes de mantê-los atualizados sobre os acontecimentos da atualidade, já que o estilo de programação televisiva que mais os atraem são: filmes (9 citações) e novelas (7 citações), enquanto o jornalismo televisivo foi mencionado apenas uma única vez. Em relação à internet, tal como apresentado anteriormente, somente três alunos alegaram utilizá-la para a leitura de noticiários.

Apesar da pouca procura entre estes estudantes pelo consumo de informação jornalística, convém conhecer quais são os periódicos tomados por eles como objeto de leitura. Iniciando pelos jornais, os mais citados foram justamente os que possuem maior índice de vendas no estado de São Paulo: Folha de S. Paulo (6 citações) e Estado de S. Paulo (5 citações). Observou-se, também, a ocorrência da indicação de leitura de duas publicações internacionais de divulgação digital: ABC Color (jornal paraguaio) e o Le monde (jornal francês), com apenas uma citação cada. Por fim, novamente com apenas uma única menção, deu-se a referência ao jornal Metro, publicação diária de distribuição gratuita. Aludindo também os jornais de distribuição gratuita, um dos alunos registrou no local destinado à descrição do nome do periódico lido a informação "Os que ganho", enquanto treze alunos não registraram o título de nenhum jornal. 
No que diz respeito à leitura de revistas (Quadro 4.1), verificou-se a preferência dos respondentes pelas publicações semanais que abordam temas variados do cotidiano, reunindo reportagens sobre política, economia e cultura, tais como Veja e Época. É importante lembrar que ambas ocupam o primeiro e segundo lugar, respectivamente, no índice de vendas da região sudeste do país e atingem como público leitor principalmente as camadas médias. Também publicada semanalmente, porém com uma inserção muito menor no mercado das publicações periódicas $^{8}$, Carta Capital obteve entre os respondentes o mesmo número de citações da revista Época. Voltada para um público distinto, caracterizado pela própria publicação em seu mídia kit $^{9}$ como pertencente às classes de elevado nível intelectual e financeiro, seus textos apresentam um caráter mais denso e intelectualizado. Outras publicações com o mesmo perfil de Carta Capital também foram citadas, tais como Piauí, Brasileiros e Caros Amigos. Publicadas mensalmente, Piauí e Brasileiros possuem um estilo jornalístico denominado literário e suas reportagens tratam de temáticas variadas nas áreas da política, economia, esporte, arte e cultura. Caros Amigos, por sua vez, aborda temáticas afins e se apresenta como publicação politicamente situada à esquerda, nomeando-se como uma "publicação contrahegemônica, alternativa e de reflexão crítica do pensamento neoliberal"10.

Revistas especializadas também foram mencionadas pelos respondentes. No âmbito dos periódicos educacionais a que contou com maior recorrência foi a revista Nova Escola, sendo a segunda mais lida considerando-se todas as revistas indicadas. As demais publicações demonstraram um leque amplo de interesses por parte dos alunos, havendo revistas que tratam de turismo, prática esportiva, Psicologia, História, Artes, além de curiosidades culturais e científicas. A abrangência de interesses dos alunos se manifestou não só por meio da diversidade temática dos periódicos, como também foi notável o fato de oito estudantes indicarem mais de uma revista como fonte de leitura.

Quadro 4.1 - Listagem das revistas lidas pelos respondentes da PUC/SP.

\begin{tabular}{ll}
\hline Categorização & Títulos \\
\hline Atualidades & Veja (9); Época (4) \\
Curiosidades culturais e científicas & Superinteressante (2) \\
Educação & Nova Escola (6); Revista Pátio (2); Educação (1) \\
Política, economia, cultura e sociedade & Brasileiros (1); CartaCapital (4); Caros amigos (1); Piauí (2) \\
Revistas especializadas & Cult (1); História (1); Psique (1); Runner's World (1); Viagem (1) \\
Celebridades & Caras (1) \\
\hline
\end{tabular}

\footnotetext{
${ }^{8}$ De acordo com o ranking do Instituto Verificador de Circulação (IVC), no primeiro semestre de 2014, Veja e Época ocuparam o primeiro e segundo lugar em vendas na região sudeste. Carta Capital, por sua vez, obteve o nonagésimo terceiro lugar na classificação geral.

${ }^{9} \mathrm{O}$ Mídia Kit é uma apresentação do periódico dirigida a potenciais anunciantes.

10 Citação obtida no site da revista em artigo denominado "História da Caros Amigos": Disponível em: <http://www.carosamigos.com.br/index.php/home/historia>. Acesso em: 13 mai. 2015.
} 
Procurando identificar relação entre a origem social dos estudantes e a leitura de periódicos, verificou-se que a leitura do jornal não é comum em nenhum dos dois grupos identificados na instituição, considerando-se as variações de renda familiar e capital cultural. No caso da leitura de revistas, foi possível identificar que os leitores assíduos, ou seja, aqueles que informaram ler muito ou regularmente (9/25), possuem renda familiar per capita acima de três salários mínimos (6/9). No que se refere à seleção dos jornais, a indicação de leitura da Folha de S. Paulo e do Estado de S. Paulo ocorre em todos os níveis de renda e formação familiar. Porém, o registro da leitura dos jornais Le monde e ABC Color ocorreram nas famílias, cujos pais possuem formação universitária e cuja renda familiar situa-se acima dos três salários mínimos per capita. Contrariamente, o aluno que indicou "Os que ganho" no espaço destinado ao registro do nome do jornal lido, possui menos de um salário mínimo como renda per capita familiar e seus familiares detém o ensino fundamental como nível mais elevado de formação. No caso da leitura de revistas, a referência aos periódicos mais vendidos (Veja, Época e Nova Escola) ocorreu em todos os níveis de renda e de instrução familiar, tal como se verificou com a leitura dos jornais Folha e Estado de S. Paulo. Porém, a indicação dos periódicos mais distintivos (jornalismo de conteúdo mais denso, crítico ou literário), tais como Brasileiros, Carta Capital, Caros Amigos, Piauí, entre outras revistas especializadas (Cult, Viagem, Runner's World), ocorreu principalmente entre os alunos cujas famílias possuem renda acima de três salários mínimos per capita e pais com nível escolar variando entre o ensino médio e superior.

Os livros foram apresentados como o material de leitura preferido dos participantes desta pesquisa. Aproximadamente três em cada quatro afirmaram lê-los muito ou regularmente, enquanto seis alunos comunicaram pouco utilizá-los. Dos vinte e cinco alunos participantes da pesquisa, vinte e um conseguiram informar o nome do último livro lido (Quadro 4.2), porém dois registros não foram identificados, por consequência da imprecisão dos dados. 


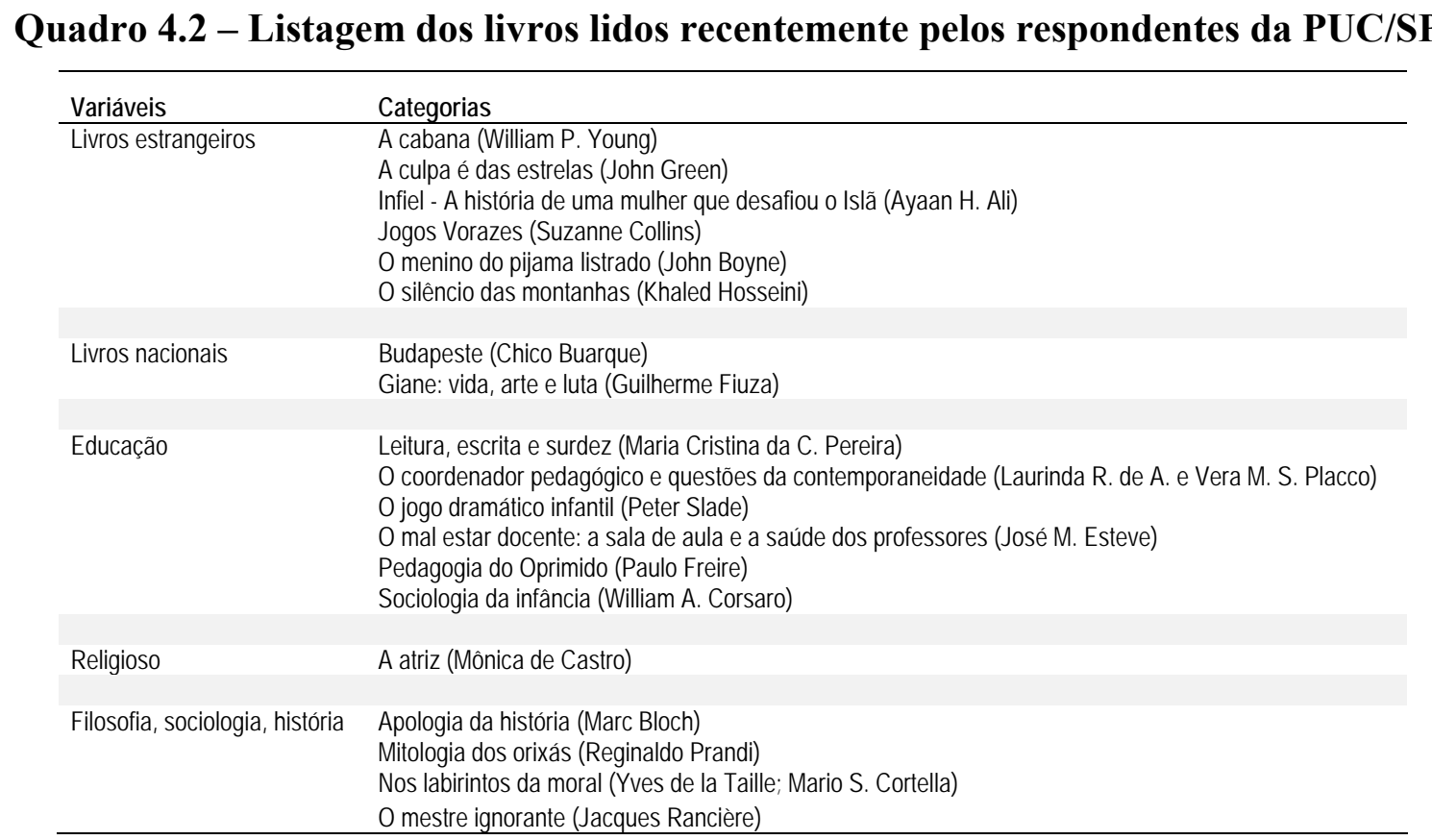

A partir dos títulos indicados, é possível notar que houve uma procura ligeiramente superior pelas obras de literatura, com destaque para a produção estrangeira. No caso desta última, observa-se uma clara preferência pelos best sellers, caracterizados por seus textos simples e voltados ao grande público, que procura o entretenimento na prática da leitura. Outro conjunto de obras que se destacou é o que se relaciona com a área de formação dos estudantes. A menção aos livros de temática educacional indica que parte dos alunos identificados como leitores ativos (leem muito ou regularmente) utilizaram seu tempo livre não em busca de lazer, mas sim como forma de complementação de sua formação universitária, por meio do acesso a informações úteis, relacionadas ao seu processo formativo profissional. Além dos livros educacionais, obras especializadas nas áreas da Filosofia, Sociologia e História também se fizeram presentes, havendo em dois casos relação da temática abordada com as questões pedagógicas, assim como se dá nas publicações de $O$ mestre ignorante (Jacques Rancière) e Nos labirintos da moral (Yves de la Taille; Mario S. Cortella).

No que se refere à leitura de livros, não foi identificada qualquer associação entre o perfil socioeconômico e cultural dos estudantes e o hábito (frequência) de leitura. Do mesmo modo, frente à indicação do nome do último livro lido, não foi constatada a existência de relação entre a preferência por um determinado gênero e os níveis renda e formação familiar. A mesma ausência de diferenciação foi notada na frequência ao cinema. Esta última prática, de modo geral, consistiu em atividade que não contou com variações significativas entre os turnos, uma vez que três em cada quatro respondentes, do período matutino e noturno, vão ao cinema de 
modo frequente ou ocasional. Esta mesma proporção (3/4) se mantém ao dividirmos os alunos de acordo com o nível de formação escolar de seus pais e nível de renda familiar.

Ao responderem a pergunta a respeito do nome do último filme visto (Quadro 4.3), dentre os vinte títulos informados ${ }^{11}$, nota-se uma clara predileção por produções de animação do cinema norte-americano ("Detona Ralph"; "Meu Malvado Favorito 2"; "Os Croods"; "Reino escondido"; "Os Smurfs 2" e "Universidade monstros"), possuindo os mesmos um enredo infantil, vinculados aos gêneros de aventura e comédia. Os filmes de comédia também orientaram as escolhas das produções nacionais ("Vendo ou alugo" e "Minha mãe é uma peça"). A observação da seleção de filmes dos respondentes revelam um padrão de consumo que tende às produções favorecidas pela divulgação midiática, voltadas ao grande público e portadoras de um conteúdo leve, que requer pouca reflexão por parte do espectador, independentemente da origem social dos alunos.

\section{Quadro 4.3 - Listagem do último filme visto no cinema pelos respondentes da PUC/SP.}

\begin{tabular}{|l|l|}
\hline Cinema americano & $\begin{array}{l}\text { As Aventuras de Pi (2012); Detona Ralph (2) (2013); Meu Malvado Favorito 2 (2) } \\
\text { (2013); Os Croods (2013); Os estagiários (2013); Reino escondido (2013); Os Smurfs 2 } \\
\text { (2013); O grande Gatsby (2013); Truque de mestre (2013); Universidade monstros (2) } \\
\text { (2013); Wolverine: imortal (2013). }\end{array}$ \\
\hline Cinema nacional & $\begin{array}{l}\text { Faroeste Caboclo (2013); Flores raras (2013); Gonzaga - De pai para filho (2012); } \\
\text { Minha mãe é uma peça (2) (2013); Vendo ou alugo (2013). }\end{array}$ \\
\hline
\end{tabular}

Outras duas atividades desenvolvidas no tempo livre dos alunos envolvem os passeios em parques e viagens. Iniciando pelos parques, trata-se de uma atividade frequente para aproximadamente metade dos respondentes $(13 / 25)$. De acordo com a pesquisa realizada no ano de 2014 pelo Instituto Datafolha e pela consultoria JLeiva Cultura \& Esporte, a respeito dos hábitos culturais dos paulistanos, foi identificado que os moradores da capital citaram os parques como o espaço cultural mais frequentado durante suas horas livres. No caso dos formandos da PUC/SP aqui investigados, constatou-se que essa prática foi frequente entre os estudantes que vivem em bairros contemplados com esse tipo de área de lazer: Ipiranga (Parque da Independência); Perdizes (Parque da Água Branca); Consolação (Parque Buenos Aires); Tucuruvi (Parque Lions Clube Tucuruvi); Tatuapé (Parque Piqueri) e Vila Mariana que faz divisa com os parques da Aclimação e do Ibirapuera. Por outro lado, entre os quatro alunos cujas respostas indicaram nunca ou raramente visitar parques, três moram em bairros que

\footnotetext{
${ }^{11}$ Cinco alunos não conseguiram lembrar o nome do último filme visto no cinema.
} 
contam com esse equipamento público: Cursino (Parque do Estado e Parque da Independência); Artur Alvim (fronteira com o Parque Linear Rio Verde) e Jardins (Parque Tenente Siqueira Campos). Contrariamente, dois moradores dos bairros Freguesia do Ó e um morador da Casa Verde que não vivem próximos de parques, mas fazem uso regular dos mesmos. Esse dado de pesquisa está de acordo com as constatações realizadas por Botelho (2004), que verificou não haver relação direta entre a disponibilidade de aparelhos culturais e seu uso. De acordo com a autora, o estudo das modalidades de práticas culturais devem levar em consideração um conjunto de fatores combinados, para além da localização da residência, tais como a origem social e econômica dos agentes.

Considerando-se a frequência aos parques, nem a origem social e econômica dos respondentes ou a localização de suas residências afetou o exercício dessa atividade, entretanto, verificou-se que o hábito de viajar possui relação direta com o nível de renda familiar, assim como a realização de práticas esportivas. De acordo com Forjaz (1988), em estudo a respeito dos hábitos de lazer e consumo cultural entre as diferentes classes sociais, é uma prerrogativa dos grupos socialmente privilegiados a utilização lúdica do próprio corpo, assim como o hábito de viajar como forma de lazer. No caso dos respondentes da PUC/SP, pouco menos da metade dos alunos afirmaram viajar frequentemente (11/25). Entre estes alunos a renda familiar per capita situa-se majoritariamente acima de dois salários mínimos. No que diz respeito à associação entre a prática esportiva e a renda familiar, verificou-se que a variação de renda não altera a disposição para a prática, mas sim a frequência e o tipo de esporte praticado. Assim, quanto mais elevadas as faixas de renda, há uma tendência da prática esportiva se tornar mais frequente, além da mesma ser praticada em academias, envolvendo modalidades como pilates, natação, hidroginástica, musculação e corrida. Por outro lado, nas faixas de renda mais baixas (abaixo de dois salários mínimos per capita) a frequência da prática esportiva tende a se tornar mais ocasional, rara ou nunca realizada.

De acordo com Bourdieu e Darbel (2007a), a renda possui relação direta com a participação dos agentes em determinadas atividades culturais. Em termos de práticas externas, deve-se considerar as despesas incluídas na compra de ingressos, bem como os custos envolvidos com o transporte. Além disso, a condição econômica do agente está diretamente associada ao seu local de residência, uma vez que populações hierarquicamente mais bem posicionadas na estrutura social tendem a morar em grandes cidades, estruturadas com uma significativa variedade de espaços culturais. Bourdieu (2007) salienta também a relação existente entre o capital econômico e a posse do tempo livre para a realização das práticas de 
cultura. Estas últimas exigem, portanto, não só o emprego de recursos econômicos, mas também o investimento de tempo para que sejam desempenhadas. Para além do aspecto econômico, há que se considerar também o grau de instrução dos agentes, uma vez que as atividades culturais exigem certo nível formativo para que as mesmas possam ser apreciadas. Nesse sentido, Bourdieu destaca que as necessidades culturais e sua apreciação estão vinculadas também à origem social dos agentes (considerando-se o volume global dos capitais econômico, social e cultural) e às experiências formativas vivenciadas pelos mesmos no âmbito escolar.

No caso brasileiro, pesquisas identificaram que grupos de menor renda possuem a propensão de serem mais ativos nas atividades culturais domésticas que envolvem a leitura, a audição musical e a assistência a filmes e programas televisivos. No âmbito das saídas culturais, são mais comuns as idas ao cinema e as participações em festas populares. Por outro lado, a frequência a museus, teatros e concertos costuma constituir práticas que requerem níveis mais elevados de renda e escolaridade (BARBOSA, 2014). De acordo com dados levantados pelo Instituto Datafolha ${ }^{12}$ (apud JLeiva Cultura \& Esporte, 2014), essas três atividades possuem a tendência de serem realizadas de modo associado, ou seja, quem possui interesse por alguma delas tende também a se interessar pelas demais, possivelmente, pela equivalência de requisitos entre os seus apreciadores. De modo correspondente, entre os alunos investigados da PUC/SP, essas três atividades foram as menos praticadas (Tabela 4.17), com destaque para os concertos de música clássica, uma vez que dez alunos afirmaram jamais tê-los frequentado. Entre estes alunos, há estudantes com perfis socioeconômicos e culturais distintos (mais ou menos privilegiados), do mesmo modo que não existe uma caracterização singular daqueles que alegaram frequentá-los de modo constante ou ocasional.

12 O levantamento realizado pelo Instituto Datafolha investigou 21 cidades do estado de São Paulo com mais de 100 mil habitantes, incluindo as 10 mais populosas, e entrevistou cerca de oito mil moradores em busca de informações sobre seus hábitos culturais no ano de 2014. 
Tabela 4.17 - Atividades culturais e de lazer realizadas com pouca frequência pelos respondentes da $\mathrm{PUC/SP}$.

\begin{tabular}{lll}
\hline Variáveis & Categorias & $\mathbf{n}$ \\
\hline Concertos & Frequentemente & 2 \\
& Ocasionalmente & 5 \\
& Raramente & 8 \\
& Nunca & 10 \\
Total & & 25 \\
Museus & Frequentemente & 3 \\
& Ocasionalmente & 12 \\
& Raramente & 6 \\
Total & Nunca & 4 \\
& & 25 \\
Teatro & Frequentemente & 4 \\
& Ocasionalmente & 8 \\
& Raramente & 12 \\
Total & Nunca & 1 \\
& & 25 \\
Total & Nunca & 12 \\
\hline
\end{tabular}

Considerando-se as visitas aos museus, trata-se de uma atividade de regularidade ocasional, que guarda pouca relação com a origem social dos respondentes, com exceção dos estudantes que mencionaram como seus museus preferidos aqueles localizados em outros países. Em meio ao grupo, esse tipo de referência ocorreu por cinco vezes, com a seguinte distribuição de menções: Museu do Louvre (2 indicações); Museu do Centro Pompidou (1 indicação); Museu de fotografia de Nova York (International Center of Photography) (1 indicação) e National Gallery (1 citação). Entre estes alunos a renda per capita familiar supera os três salários mínimos mensais e o grau de instrução familiar varia do ensino médio (em dois casos) à formação superior (em três casos). Entre os museus nacionais, contaram com maior número de referências o museu dedicado às ciências - Catavento cultural (8 indicações) e o Museu da Língua Portuguesa (6 indicações).

Com relação aos espetáculos teatrais, não foram verificadas variações de frequência relacionadas ao nível de renda. Entretanto, em meio aos praticantes frequentes e ocasionais, identificou-se uma maior recorrência de familiares portadores do diploma universitário. No que se refere aos espetáculos assistidos em data recente à realização da pesquisa (Quadro 4.4), foram citados dezenove títulos, os quais permitiram identificar a preferência pelos musicais e apresentações voltadas ao público infantil, reiterando o mesmo critério de seleção dos filmes assistido por estes alunos no cinema. 
Quadro 4.4 - Lista da última peça de teatro assistida - PUC/SP.

\begin{tabular}{lll}
\hline Títulos mencionados & Não souberam informar \\
\hline & & \\
A Bela e a Fera (musical); Aos nossos filhos (2); Cabaret & & \\
(musical); Em nome do jogo; Hamlet; Improvável (2); Inês & 6 alunos \\
Teatro & - Gil Vicente por ele mesmo; O Circo do Seu Lé; O Rei \\
& Leão (musical) (4); Priscilla, a rainha do deserto (musical); & \\
& Tudo o que eu queria te dizer; Vale encantado (musical). \\
& \\
\end{tabular}

O estudo do perfil social dos respondentes da PUC/SP permitiu a identificação de dois subgrupos com características distintas. O primeiro e mais prevalecente, caracteriza-se por alunos oriundos de famílias com renda per capita mensal acima de dois salários mínimos, sendo os mesmos filhos de pais com formação universitária e dedicados a ocupações profissionais socialmente valorizadas. A trajetória escolar destes alunos deu-se em escolas particulares, no período diurno e na modalidade regular. Por outro lado, distanciando-se dessas características mais recorrentes, foi observada a existência de um grupo menor e, ao mesmo tempo, menos privilegiado em relação ao primeiro. Neste segundo agrupamento, localizam-se aqueles alunos cuja formação escolar ocorreu em instituições públicas de ensino, enquanto o ensino médio foi cursado no período noturno, uma vez que durante o dia o tempo destes estudantes foi dedicado ao trabalho. Em meio a estes alunos a formação escolar dos pais mais frequente vincula-se ao ensino fundamental e médio e a renda per capita familiar mensal é aquela situada abaixo de dois salários mínimos, estando entre eles os cursistas que contaram com bolsas de estudo para o ingresso e permanência no ensino superior.

A partir do reconhecimento da existência destes dois grupos, deu-se o esforço de investigar a ocorrência de práticas culturais distintivas entre os mesmos. Dentre as atividades culturais identificadas como mais frequentes, apesar da ausência de diferenciações em relação à origem social dos alunos e suas práticas de leitura de livros e escolhas cinematográficas, verificou-se a existência de especificidades em relação ao gosto musical, bem como na seleção de revistas e, em menor proporção, na escolha dos jornais. Enquanto a indicação da escuta da MPB, da leitura dos jornais Folha de S. Paulo e do Estado de S. Paulo e das revistas Época e Veja, ocorreram de forma indistinta entre os diferentes grupos, a maior visibilidade do habitus de classe entre estes respondentes se deu por meio da ocorrência de indicações de escolhas diferenciadas seja na área da música, como na leitura de jornais e revistas. Assim ouvir samba, blues e reggae; ler jornais internacionais (Le monde e $A B C$ Color) e revistas especializadas (Cult, Viagem, Runner's World) e portadoras de artigos mais densos (Brasileiros, CartaCapital, 
Caros Amigos, Piauí) são práticas que se mostraram comuns entre os respondentes que pertencem a famílias com níveis mais elevados de renda e formação cultural. Por outro lado, confirmando os resultados de pesquisas na área das práticas culturais, entre os respondentes pertencentes a famílias com níveis de renda e formação cultural mais baixos, o gosto musical tendeu a gêneros como o pagode, o sertanejo e o gospel, além de se verificar a quase ausência do hábito da leitura de jornais e revistas, cujas citações abrangeram os periódicos de grande circulação.

Considerando-se as práticas culturais externas - concerto, teatro e museu - todas contaram com uma baixa adesão por parte dos respondentes, independentemente do nível de renda e escolaridade dos pais. No entanto, entre os alunos que frequentam o teatro de forma recorrente ou ocasional, foi possível verificar que os mesmos possuem pais com formação predominantemente universitária. Atentando para os efeitos da condição econômica, por outro lado, foi possível identificar que as visitas aos museus internacionais, bem como o hábito de viajar no tempo livre e a prática esportiva (frequência e modalidade), possuem relação direta com o capital econômico de suas famílias de origem.

\subsection{ESCOLHER OU ADEQUAR-SE? TRANSFORMAR OU ACEITAR? EDUCAR OU AMAR? ESTAR NA ESCOLA OU FORA DELA? AS CONTRADIÇÕES DE UM GRUPO}

O estudo do processo de escolha profissional vivenciado pelos respondentes da PUC/SP indicou que mais da metade dos alunos (16/25) desejava desde o início cursar a graduação em Pedagogia. Por outro lado, nove alunos não tinham essa formação profissional como sua primeira opção formativa. Entre estes últimos, a mudança na definição do curso a ser seguido foi motivada por restrições econômicas (5/9); pela identificação de características pessoais entendidas como mais ajustadas à pedagogia (3/9) e por interferência familiar e de amigos (1/9), frente à ausência de uma escolha pessoal claramente estabelecida: "Fui muito influenciada a prestar para o curso de Pedagogia por amigos e familiares que diziam que eu tinha o perfil para a profissão. Eu mesma não sabia o que queria fazer profissionalmente."

A influência dos condicionamentos econômicos afetou os alunos a partir de restrições relacionadas com o valor da mensalidade; período em que o curso é ministrado e também com as oportunidades de trabalho que a graduação inicialmente escolhida proporcionaria. A graduação em Psicologia na PUC/SP, formação desejada a princípio por quatro estudantes, apresentou para estes alunos dois desses obstáculos. O primeiro diz respeito ao fato do curso ser ministrado durante período integral, impossibilitando o trabalho concomitante ao curso, 
enquanto a segunda barreira tem relação com o valor da mensalidade, sendo esta mais que o dobro do custo mensal referente ao curso de Pedagogia ${ }^{13}$. O mesmo se dá em relação ao curso de Jornalismo (opção inicial de um dos respondentes) que, apesar não exigir dedicação integral, possui um valor de mensalidade bastante elevado (aproximadamente mil reais a mais) se comparado ao custo do curso de Pedagogia.

Além das restrições financeiras relativas ao início do curso, as respostas dos alunos indicaram também a realização de uma escolha profissional guiada por uma estratégia de investimento escolar que afastou de imediato as profissões de risco, assim entendidas pelo fato de não oferecerem a certeza de ganhos financeiros após o encerramento do curso e até mesmo durante a realização do mesmo: “(...) quando entrei na universidade optei pela Pedagogia por ser mais fácil de arrumar estágio”. Diante dessa preocupação, a graduação em Pedagogia mostrou-se para estes estudantes como mais promissora que as formações nas áreas de Jornalismo, Teatro e Psicologia, tal como ilustram os relatos a seguir:

"O curso era caro (Jornalismo) e encontraria dificuldades para me colocar no mercado de trabalho.";

"Ter um curso superior como Pedagogia me dava mais garantia para seguir posteriormente para o Teatro.”

A partir dessas declarações, é possível observar a vivência de um processo de readequação das escolhas profissionais, decorrente de um conhecimento prático incorporado (habitus) que promove o ajuste da conduta dos agentes ao que lhes é viável, tendo em vista sua condição social de origem. Esse movimento de adaptação, não consciente, abrange um processo de autoseleção do candidato que estima suas chances objetivas de concretização dos estudos superiores e de sucesso futuro, a partir da realidade social concreta na qual está inserido. Ao final desse processo a decisão tomada é compreendida pelo estudante como a manifestação de uma escolha orientada por sua identidade pessoal: "Na verdade eu estava em dúvida quanto ao curso (Psicologia) e acabei por optar por Pedagogia por me identificar com a área."; Tenho afinidade com crianças", que registram por parte dos alunos a crença na posse de uma inclinação pessoal para uma profissão que, na realidade, lhes foi designada socialmente.

Por outro lado, considerando todos os respondentes, independentemente da escolha do curso resultar de primeira ou segunda opção, e as razões que os levaram a optar pela graduação

\footnotetext{
${ }^{13}$ De acordo com informações oferecidas pela instituição o valor da mensalidade do curso de Psicologia é de R\$ $2.624,00 *$. O curso de Jornalismo, por sua vez, custa $\mathrm{R} \$ 2.143,00 *$, enquanto a graduação em Pedagogia cobra uma mensalidade no valor de $1.200,00 *$ reais. *Valores praticados no primeiro semestre de 2015.
} 
em Pedagogia, foi constatado um significativo interesse pelas possibilidades de atuação profissional propiciadas pelo curso (12/25). Estes estudantes destacaram, por um lado, o desejo de atuarem como docentes (9/12): "Sempre quis ser educadora”; “A vontade de participar da formação do ser humano", enquanto outra parte justificou a escolha profissional pela oportunidade de trabalhar com crianças (3/12) “Afinidade com as crianças e com a educação"; “Amor pela educação das crianças”. É importante destacar que, para este grupo de alunos, o exercício da profissão é visto como capaz de proporcionar o alcance de realização pessoal "Vontade de dar aula, fazer algo que me deixasse feliz"; "Querer fazer algo, além de trabalhar, fazer algo que fosse significativo para mim” ou, até mesmo, o cumprimento de uma missão: “A minha opção de vida como religiosa. Nossa missão é trabalhar com a educação.", revelando resquícios dos sentidos vocacionais e de sacerdócio historicamente associados ao trabalho docente, dada a origem religiosa da profissão (ROMANELLI, 2001).

Outro grupo de alunos (5/25) utilizou como argumento para sua escolha profissional a dimensão social do magistério. Em suas justificativas, foram destacadas a importância da educação e da ação docente no aprimoramento da formação dos jovens, ação esta que teria por consequência a transformação social: "Acredito que as crianças influenciem seus pais e através disso possamos modificar a realidade.” Entre estes alunos a escolha da profissão é justificada pelo enaltecimento da atividade docente e da ação educacional: "Creio na importância do educador na sociedade atual e gostaria de contribuir (...)”, ao mesmo tempo que demonstram sua credulidade na existência de uma relação direta entre a atividade pedagógica e a promoção do bem comum:

“Acreditar que a educação é uma grande arma para mudança de sociedade.”;

"A vontade de transformar o sistema educacional brasileiro e acreditar que a educação é a arma mais valiosa para mudar o mundo."

O interesse pela área educacional também foi apontado como motivo de escolha do curso (5/25). Neste caso, os respondentes expressaram a disposição em aperfeiçoar sua prática profissional, condição específica de quem já atuava na área antes mesmo de iniciar o curso, seja como professor (4/5) "O meu trabalho como docente, o interesse pela educação e o desejo de estabelecer relações entre as minhas formações iniciais e esta área de conhecimento.”; "Busca por um maior aperfeiçoamento na profissão docente. Agregar currículo” ou como voluntário (1/5) “Meus trabalhos voluntários são feitos em maior parte nas instituições infantis e eu sentia a necessidade de compreender melhor este mundo.” 
Por fim, de forma menos recorrente (3/25), os alunos apontaram a participação de familiares e professores próximos como agentes que influenciaram na definição da profissão a ser seguida: "Influência de amigos e familiares"; "Vivência com muitos professores na família" e "Influência de uma professora do ensino médio", demonstrando o modo como as relações desenvolvidas no meio familiar e escolar foram fundamentais, para estes alunos, na determinação da profisssão a ser seguida.

A partir dos depoimentos, foi possível observar, portanto, quatro tipos de motivações para a escolha da profissão entre os respondentes da PUC/SP. O primeiro e mais numeroso grupo demonstrou o interesse pelo exercício da docência; o segundo grupo foi movido pela posse de um compromisso social; o terceiro grupo desejava aprofundar seus conhecimentos na área e o último grupo foi incentivado pela ação familiar. Empregadas do mesmo modo pelos alunos que tinham ou não a Pedagogia como sua primeira opção formativa, essas justificativas também não estão associadas a uma determinada faixa de renda. Com exceção dos alunos que destacaram a influência familiar e os que buscavam o aperfeiçoamento profissional, chama a atenção a força do discurso missionário como justificativa para a decisão de cursar a graduação em Pedagogia. Nessas manifestações, faz-se presente a concepção do trabalho do pedagogo orientado pelo propósito de auxiliar o próximo e contribuir para a promoção social, ao mesmo tempo que estes alunos esperam se dedicar a uma causa e atribuem à profissão uma elevada capacidade de remediar os males sociais.

A perspectiva social do trabalho docente foi novamente destacada pelos participantes da pesquisa (9/25) ao procurarem apresentar sua concepção a respeito do significado de ser professor. Em seus argumentos são sublinhados o ideário do professor cuja atuação deve ser voltada para a formação do cidadão, por meio do preparo de alunos críticos e politizados, capazes de intervir ativamente na sociedade:

“O professor é uma peça fundamental para o desenvolvimento da sociedade.”;

“É o professor quem convida seus estudantes para passarem por um longo processo de reflexão, criticidade, elaboração de conceitos e posicionamentos políticoideológicos e mudanças efetivas em suas próprias vidas e em todo o seu contexto social, de modo que a autonomia os conduza para um exercício pleno da cidadania.”.

A docência também foi explicada por estes alunos como atividade essencialmente voltada para o conhecimento (8/25), o qual poderá ser compartilhado, construído ou mediado: "Um ser que partilha seus conhecimentos e colabora para a elaboração do conhecimento dos seus alunos.”; “Indicar o caminho para a construção do conhecimento”; “Mediador do 
conhecimento”. A partir dessas declarações, torna-se evidente a existência entre estes alunos de uma concepção pedagógica que recusa o modelo tradicional de ensino, cabendo ao professor proporcionar ao aluno uma situação de aprendizagem pautada pela autonomia e aprendizagem ativa. Por outro lado, deve-se enfatizar a existência neste pequeno grupo de uma visão que valoriza a finalidade central do trabalho docente, qual seja, a relação com o conhecimento e a promoção da aprendizagem por parte de seus alunos.

Concepções menos recorrentes definiram o "ser professor" a partir de uma percepção que ressalta as dificuldades que envolvem o trabalho docente, tais como "enfrentar desafios diários”; "É gostar da profissão, ter paciência e ser guerreiro"; "estudar muito e não ser valorizado" (4/25). Ao mesmo tempo, imbuídos de uma concepção romântica acerca da profissão, uma pequena parcela do grupo de alunos investigados $(3 / 25)$ ressaltou a dimensão afetiva da atividade docente, por meio de afirmações como: "Professor é saber acolher"; “Educar com amor”; “Cuidar”. Considerando-se esses relatos, é possível observar que os alunos demonstram uma certa clareza a respeito das dificuldades que envolvem o trabalho docente, porém o discurso crítico ( "estudar muito e não ser valorizado") se faz menos presente em relação à visão que prega a submissão às adversidades, por meio de posturas que envolvem “gostar da profissão” e ser paciente. Trata-se, portanto, de um movimento de enfrentamento das dificuldades da profissão a partir da mobilização de recursos pessoais que envolvem a emoção e o afeto, resultado de uma compreensão simplificada acerca dos problemas educativos e de sua superação, situados no âmbito do devotamento docente ante o exercício de sua atividade profissional (SILVA, 2012). Novamente retomada pelos alunos, ao descreverem a docência a partir do exercício de atitudes que envolvem o carinho, o acolhimento e o amor, a dimensão afetiva também representa a atribuição de uma importância maior às dimensões pessoais docentes, do que propriamente aos saberes profissionais.

Em termos de planos envolvendo o exercício da profissão, os alunos indicaram uma grande tendência de permanecerem na área educacional. Somente uma aluna do grupo que inicialmente não tinha o curso de Pedagogia como objetivo formativo, indicou o desejo de não atuar na área e cursar a graduação que sempre pretendeu (Teatro). O registro das atividades profissionais que esperam desenvolver após a conclusão do curso demonstra que boa parte dos alunos (15/25) pretende trabalhar como professor de educação infantil ou ensino fundamental, havendo uma leve predileção pelas instituições particulares de ensino (9/15) em relação aos estabelecimentos públicos (6/15). Os demais alunos (9/25) informaram intenções profissionais diversificadas que variam da atuação na área da administração escolar (direção ou coordenação 
pedagógica); o trabalho com formação de professores; atuação como pedagogo em contexto diversificado (hospitais, ONGs...) e ensino a distância.

Parte desses alunos identificou o desejo de não atuar em sala de aula a partir da experiência de estágio vivenciada durante o curso. Enquanto vinte estudantes afirmaram que o estágio não modificou seus planos profissionais, oferecendo para alguns a certeza da escolha profissional realizada “[o estágio] só confirmou minha vontade de trabalhar com a educação”, para um grupo pequeno de alunos $(5 / 25)$ a prática do estágio fez com que percebessem a ausência de uma identificação pessoal com os espaços de atuação associados à formação em pedagogia, seja em relação à escola ou ao ambiente da sala de aula: “Confesso que o estágio me fez observar aspectos da escola que até então desconhecia, me fazendo refletir sobre a escolha da carreira.” ; “[ o estágio] me fez ter certeza de que o sistema escolar atual não funciona e que não quero atuar em escolas.”. Como solução os mesmos passaram a vislumbrar a possibilidade de trabalho em outras atividades, ainda na área da educação:

“Quando atuei no administrativo me identifiquei mais do que em sala de aula.”;

"Pude perceber as variadas funções que um pedagogo pode assumir na escola e em outros espaços." e "Hoje me imagino muito mais na área da pesquisa e de coordenação pedagógica, por exemplo.”

Tal como ilustra o último depoimento, além da perspectiva de atuação em atividades outras, distantes da sala de aula e do ambiente escolar, é manifesta nestes cinco alunos a expectativa de continuidade dos estudos seja por meio do envolvimento em pesquisas acadêmicas; cursos de especialização ou até mesmo pela frequência de um novo curso de graduação. A tendência da continuidade dos estudos, porém, é observada em praticamente todo o grupo de respondentes, uma vez que catorze alunos pretendem frequentar cursos de especialização; seis desejam seguir na área da pesquisa acadêmica e dois querem cursar uma nova graduação.

A associação dos planos profissionais dos respondentes aos seus projetos formativos após a conclusão do curso oferecem a compreensão da existência de um alto nível de adesão dos alunos à profissão. Ao mesmo tempo, demonstra a valorização do conhecimento e a percepção da necessidade de vivenciarem um processo formativo continuado, voltado preferencialmente para os cursos de especialização, evidenciando o interesse pelo aperfeiçoamento profissional por meio da aquisição de habilidades específicas ao seu campo de atuação. Esse interesse também pode ser interpretado como uma estratégia de investimento escolar, orientadora das práticas que buscam na formação institucionalizada meios de manter 
ou elevar a posição ocupada no interior da estrutura social. Tal estratégia, por sua vez, resulta da posse de um senso prático do sentido do jogo, disputado entre os agentes sociais que estão mais próximos entre si e contra quem "a concorrência é mais direta e imediata", os quais lutam pela manutenção das distâncias, ou seja, por sua distinção (BOURDIEU, 2007, p.60). Há que se destacar, porém, que o efeito distintivo resulta da raridade dos títulos. Assim, a corrida massificada em busca dos cursos de pós-graduação, tem por consequência a anulação do efeito de diferenciação cultural. A manifestação generalizada do desejo de seguir estudando, expressa, na verdade, um modo de agir orientado pelo esforço dos agentes de manterem sua posição "onde só se pode conservar mudando", ou seja, participando das lutas de concorrência que nunca cessam de perpetuar as diferenças entre os grupos sociais (BOURDIEU, 2013, p. 195).

$*$

O estudo do perfil socioeconômico dos formandos do curso de Pedagogia da PUC-SP envolvidos nesta investigação, indicou a existência de dois grupos portadores de características distintas: uns possuem origem social relacionada a famílias mais escolarizadas e detentoras de maiores níveis de renda, outros (em menor proporção) cursaram sua educação básica em escolas públicas, trabalharam durante o ensino médio e só ingressaram nessa universidade por contarem com a posse de bolsas de estudo e financiamento estudantil.

Em termos de práticas culturais, verificou-se o predomínio daquelas desenvolvidas no ambiente doméstico, independente da origem social dos respondentes. Porém, notou-se que a elevação dos níveis de renda e formação familiar, bem como trajetórias escolares relacionadas ao ensino privado, produziram o interesse por músicas distintivas (tais como MPB, blues, samba), bem como o estabelecimento do hábito de leitura de revistas e jornais estrangeiros. Mais regulares em meio ao grupo, as idas ao cinema e a leitura de livros se relacionaram com os dois perfis sociais identificados, havendo uma preferência generalizada pelos filmes norteamericanos e livros voltados ao grande público, portadores de conteúdo leve e que pouco exigem por parte dos seu público/leitores em termos de formação cultural prévia.

A escolha profissional pelo curso de Pedagogia, para uma pequena parte dos investigados, ocorreu por limitações de ordem objetiva que envolveram o abandono de cursos com mensalidades elevadas; ministrados em turnos integrais e que ofereciam pouca possibilidade de inserção profissional. Essa mudança de rumo profissional não ocorreu somente em meio aos alunos portadores de condições econômicas mais desprivilegiadas, mas se deu 
também entre aqueles detentores de uma faixa de renda familiar que os relacionaria às camadas sociais médias. Mesmo diante dessa mudança inicial de planos profissionais, foi identificado em meio ao respondentes um grande interesse de permanência na profissão, sobretudo na condição de professores em escolas particulares. No que se refere aos planos formativos, os respondentes manifestaram uma forte expectativa de especializarem seus conhecimentos no âmbito da pós-graduação.

Por fim, suas representações sobre a profissão destacaram, em maior grau de recorrência, a função social do trabalho docente (envolvendo a perspectiva da formação do cidadão) e a ação pedagógica do professor que privilegia o ensino e a aprendizagem dos seus educandos, numa perspectiva claramente distanciada da concepção tradicional de ensino. 


\section{DA CLAREZA NA ESCOLHA À CERTEZA DO SENTIDO SOCIAL DA PROFISSÃO}

\subsection{O PERFIL SOCIAL DOS RESPONDENTES DO CURSO DE PEDAGOGIA DA USP-SP: A FRAÇÃO INTERMEDIÁRIA DAS CARREIRAS POPULARES}

Os respondentes que cursavam à época o último ano do curso de Pedagogia da USP caracterizam-se pela composição de um grupo predominantemente composto por mulheres, brancas, solteiras e sem filhos (Tabela 5.1). Quanto à idade dos estudantes, destaca-se a faixa etária que varia dos vinte aos vinte e cinco anos, havendo, porém, uma maior concentração de alunos com 21 e 22 anos de idade (22/44). Considerando o fato do curso durar idealmente nove semestres, pode-se supor que metade do grupo etário mais representativo ingressou no curso de Pedagogia com a idade entre 18 e 19 anos.

Tabela 5.1 - Distribuição dos respondentes da FEUSP segundo as variáveis sexo, idade, raça, estado civil e número de filhos.

\begin{tabular}{|c|c|c|c|c|c|}
\hline Variáveis & Categorias & $\mathrm{n}^{1}$ & Diurno & Noturno & Desistentes \\
\hline \multirow[t]{2}{*}{ Sexo } & Feminino & 65 & 20 & 41 & 4 \\
\hline & Masculino & 10 & 2 & 7 & 1 \\
\hline Total & & 75 & 22 & 48 & 5 \\
\hline \multirow[t]{3}{*}{ Faixa etária } & 20 a 25 & 44 & 17 & 23 & 4 \\
\hline & 26 a 30 & 16 & 0 & 16 & 0 \\
\hline & 31 ou mais & 15 & 5 & 9 & 1 \\
\hline Total & & 75 & 22 & 48 & 5 \\
\hline \multirow[t]{5}{*}{ Raça } & Branco & 52 & 16 & 32 & 4 \\
\hline & Pardo & 13 & 1 & 12 & 0 \\
\hline & Preto & 3 & 0 & 3 & 0 \\
\hline & Indígena & 1 & 0 & 0 & 1 \\
\hline & Amarelo & 6 & 5 & 1 & 0 \\
\hline Total & & 75 & 22 & 48 & 5 \\
\hline \multirow[t]{2}{*}{ Estado conjugal } & Casado & 18 & 4 & 13 & 1 \\
\hline & Solteiro & 57 & 18 & 35 & 4 \\
\hline Total & & 75 & 22 & 48 & 5 \\
\hline \multirow[t]{2}{*}{ Filhos } & Sim & 13 & 3 & 10 & 0 \\
\hline & Não & 62 & 19 & 38 & 5 \\
\hline Total & & 75 & 22 & 48 & 5 \\
\hline
\end{tabular}

A divisão dos respondentes entre os turnos indicou que os homens estudam preferencialmente no período noturno, horário que também compreende mais da metade dos

\footnotetext{
${ }^{1}$ Considerando o modo como o levantamento dos dados foi realizado nesta instituição, a partir de um email convite, dirigido aos formandos e disparado pela seção de alunos da faculdade, a pesquisa contou com a participação voluntária de inicialmente 75 alunos. Ao longo do questionário, porém, ocorreram algumas desistências, atingindo a investigação um número final de 53 participantes. Tais desistências ocorreram progressivamente no decorrer da pesquisa e essa condição produziu variações no número de respostas obtidas, tal como será observado no decorrer deste capítulo.
} 
alunos com idade superior aos vinte e seis anos e praticamente a totalidade dos alunos negros (dos dezesseis alunos negros participantes da pesquisa, quinze estudam no período noturno). Já no período vespertino, observou-se uma presença maior de estudantes mais jovens e uma proporção levemente superior de alunos solteiros e sem filhos.

Os dados relativos à trajetória escolar durante a formação básica (Tabela 5.2) indicam que a escolarização dos alunos do período vespertino ocorreu com maior incidência no setor privado, enquanto, entre os respondentes do noturno, observa-se que o ensino fundamental foi cursado predominantemente em escolas públicas e, no ensino médio, nota-se uma distribuição equilibrada entre os alunos que passaram pelas escolas particulares e públicas. Uma análise mais detida da formação durante o ensino médio indica que o mesmo foi concluído fundamentalmente no estado de São Paulo, na modalidade regular e no período matutino, em ambos os turnos. O índice de trabalho nesta etapa da formação escolar não foi elevado, conforme observado na Tabela 5.3; porém, maior número de alunos que tiveram de conciliar os estudos com as atividades remuneradas cursavam a graduação em Pedagogia no período noturno, estando entre eles também os alunos que se dedicaram a jornadas de trabalho mais longas (acima de 31 horas semanais).

Tabela 5.2 - Distribuição dos respondentes da FEUSP segundo a trajetória escolar no ensino médio.

\begin{tabular}{|c|c|c|c|c|c|}
\hline Variáveis & Categorias & $\mathrm{n}$ & Diurno & Noturno & Desistentes \\
\hline \multirow[t]{3}{*}{ Ensino Fundamental } & Público & 32 & 3 & 28 & 1 \\
\hline & Público/Privado & 9 & 2 & 7 & 0 \\
\hline & Privado & 32 & 17 & 13 & 2 \\
\hline Total & & 73 & 22 & 48 & 3 \\
\hline \multirow[t]{3}{*}{ Ensino Médio } & Público & 33 & 7 & 25 & 1 \\
\hline & Público/Privado & 2 & 1 & 1 & 0 \\
\hline & Privado & 38 & 14 & 22 & 2 \\
\hline Total & & 73 & 22 & 48 & 3 \\
\hline \multirow[t]{4}{*}{ Local de conclusão do Ensino Médio } & SP & 70 & 21 & 46 & 3 \\
\hline & MG & 1 & 0 & 1 & 0 \\
\hline & PR & 1 & 1 & 0 & 0 \\
\hline & RJ & 1 & 0 & 1 & 0 \\
\hline Total & & 73 & 22 & 48 & 3 \\
\hline \multirow{4}{*}{ Modalidade do Ensino Médio } & Regular & 65 & 18 & 45 & 2 \\
\hline & & 1 & 0 & 1 & 0 \\
\hline & Normal/magistério & 2 & 1 & 0 & 1 \\
\hline & Técnico/profissional & 5 & 3 & 2 & 0 \\
\hline Total & & 73 & 22 & 48 & 3 \\
\hline \multirow[t]{2}{*}{ Turno do Ensino Médio } & Matutino & 63 & 22 & 39 & 2 \\
\hline & Noturno & 10 & 0 & 9 & 1 \\
\hline Total & & 73 & 22 & 48 & 3 \\
\hline \multirow{2}{*}{ Trabalho no Ensino Médio } & Sim & 21 & 5 & 15 & 1 \\
\hline & Não & 52 & 17 & 33 & 2 \\
\hline Total & & 73 & 22 & 48 & 3 \\
\hline
\end{tabular}


Tabela 5.3 - Distribuição dos respondentes da FEUSP segundo a jornada de trabalho e cursinho no ensino médio.

\begin{tabular}{|c|c|c|c|c|c|}
\hline Variáveis & Categorias & $\mathrm{n}$ & Diurno & Noturno & Desistentes \\
\hline \multirow[t]{4}{*}{ Jornada de trabalho no Ensino Médio } & Até $20 \mathrm{~h} / \mathrm{s}$ & 10 & 4 & 6 & 0 \\
\hline & De 21 a $30 \mathrm{~h} / \mathrm{s}$ & 3 & 1 & 2 & 0 \\
\hline & De 31 a $40 \mathrm{~h} / \mathrm{s}$ & 1 & 0 & 1 & 0 \\
\hline & Mais de $40 \mathrm{~h} / \mathrm{s}$ & 7 & 0 & 6 & 1 \\
\hline Total & & 21 & 5 & 15 & 1 \\
\hline \multirow[t]{2}{*}{ Frequentou cursinho } & Sim & 43 & 14 & 28 & 1 \\
\hline & Não & 30 & 8 & 20 & 2 \\
\hline Total & & 73 & 22 & 48 & 3 \\
\hline \multirow[t]{3}{*}{ Tempo de espera para ingresso no Ensino Superior } & Até um ano & 41 & 11 & 28 & 2 \\
\hline & De 2 a 4 anos & 19 & 7 & 12 & 0 \\
\hline & 5 anos ou mais & 13 & 4 & 8 & 1 \\
\hline Total & & 73 & 22 & 48 & 3 \\
\hline
\end{tabular}

Ainda a respeito do processo formativo destes estudantes, verificou-se que trinta e cinco deles, de setenta e três respondentes, já haviam iniciado outro curso de graduação anteriormente à formação em Pedagogia (Tabela 5.4). Destes, dezenove alunos concluíram suas formações nas áreas de Ciência da Computação; Ciências Sociais; Dança; Direito; Enfermagem; Farmácia e Bioquímica; Filosofia; História (5); Letras (4); Tecnologia em Marketing e Turismo. Esses alunos, já graduados, cursaram a Pedagogia predominantemente no período noturno (17/19). Considerando, por outro lado, os estudantes que têm na formação em Pedagogia sua primeira inserção em um curso de formação superior (38/73), observou-se que pouco mais da metade (21/38) ingressou nesta graduação menos de um ano após a finalização do ensino médio. Entre esses alunos, sete recorreram ao preparo em cursinhos prévestibulares, por períodos que variaram de menos de um semestre a um ano. Os demais estudantes (14/38), de modo geral, permaneceram no cursinho pelo tempo correspondente ao intervalo entre a finalização do ensino médio e o ingresso no ensino superior. Essa relação, porém, não se aplica para os alunos que levaram quatro ou mais anos para iniciar o curso de Pedagogia, já que entre eles o tempo de preparo em cursinhos foi muito disperso.

Tabela 5.4 - Distribuição dos respondentes da FEUSP não graduados anteriormente, em relação ao tempo de permanência no cursinho e intervalo entre a finalização do ensino médio e ingresso no curso de Pedagogia.

\begin{tabular}{lccccccc}
\hline $\begin{array}{l}\text { Tempo de ingresso no curso de } \\
\text { pedagogia como primeira } \\
\text { graduação, após o ensino médio }\end{array}$ & Não & Até 1 & 1 sem a & 1 a 1,5 & 1,5 a 2 & Acima de \\
& frequentou & sem & 1 ano & ano & anos & 2 anos & Total \\
Menos de um ano & 14 & 2 & 5 & 0 & 0 & 0 & 21 \\
Um ano & 1 & 0 & 4 & 0 & 0 & 0 & 5 \\
Entre 2 e 3 anos & 1 & 0 & 1 & 0 & 4 & 2 & 8 \\
Quatro anos ou mais & 1 & 1 & 1 & 0 & 0 & 1 & 4 \\
Total & 17 & 3 & 11 & 0 & 4 & 3 & 38 \\
\hline
\end{tabular}


Independentemente da intenção formativa inicial dos alunos, considerando-se o ingresso na Pedagogia ou em outras carreiras, observa-se, na Tabela 5.5, que a procura por cursinhos preparatórios para o vestibular não sofreu grandes variações. Assim, há uma proporção ligeiramente superior de alunos que frequentaram cursinhos, seja entre os que intencionavam cursar a graduação em Pedagogia ou entre aqueles que planejavam seguir carreiras diferentes, tal como ilustra a Tabela 5.5:

Tabela 5.5 - Distribuição dos respondentes da FEUSP não graduados anteriormente, quanto à frequência a cursinhos e a escolha do curso de pedagogia como primeira ou segunda opção formativa.

\begin{tabular}{lll}
\hline Variáveis & Categorias & $\mathbf{n}$ \\
\hline Pedagogia primeira opção & Sim & 21 \\
& Não & 11 \\
Total & & 32 \\
Cursinho entre os que tinham a pedagogia primeira opção & Sim & 12 \\
Total & Não & 09 \\
& & 21 \\
Cursinho entre os que tinham a pedagogia como segunda opção & Sim & 7 \\
& Não & 4 \\
Total & & 11 \\
\hline
\end{tabular}

Assim, a partir dessas informações, pode-se afirmar que pouco mais da metade dos alunos que tinham a Pedagogia como sua primeira graduação ingressou no curso tão logo se deu a finalização do ensino médio (21/38). Entre estes alunos, mais da metade (14/21) não frequentou cursinhos. Por outro lado, grande parte dos estudantes (14/17) que levou mais de um ano após o encerramento do ensino médio para ingressar na Pedagogia, frequentou cursinhos, sem que fosse identificado um tempo de preparo maior entre os que tinham ou não a Pedagogia como sua primeira opção de formação profissional.

Considerando o grau de instrução familiar dos respondentes (Tabela 5.6), nota-se o predomínio da formação universitária em ambos os turnos. No período vespertino, entretanto, há um maior número de pais com nível de instrução superior (14/22), enquanto no período noturno a contagem de pais com formação universitária é ligeiramente menor (21/45), elevando-se, proporcionalmente, a fração daqueles formados no ensino médio (13/45) e fundamental (11/45). Quanto às mães, novamente o período vespertino reúne o grupo com maior nível de escolaridade, havendo quase uma condição de equilíbrio entre as portadoras do diploma universitário (10/22) e as que concluíram o ensino médio (9/22). No ensino noturno, porém, apesar do ensino superior prevalecer, há uma proporção menor de mães universitárias, 
enquanto há um número maior de portadoras do diploma de ensino fundamental e médio como o grau de instrução mais elevado obtido. Quanto ao tipo de ocupação profissional desempenhada, notou-se que uma parcela das mães com ensino superior (4/31) e ensino médio (11/23), de ambos os turnos, não atua em áreas correspondentes ao seu nível de formação escolar, dedicando-se as mesmas à atividades que exigem um menor nível de instrução, geralmente como donas de casa. Entre as portadoras do grau universitário e que atuam em atividades profissionais correspondentes ao nível de instrução obtido (27/31), doze são professoras (12/27), enquanto as demais trabalham como psicólogas, médicas, administradoras de empresa, arquitetas e assistentes sociais. Em relação aos pais, os que possuem nível superior dividem-se entre funcionários de empresas privadas (12/35); professores (9/35); comerciantes e autônomos (6/35); funcionários públicos (5/35) e profissionais liberais (3/35).

Tabela 5.6 - Distribuição dos respondentes da FEUSP segundo o nível de instrução paterno e materno e ocupação desenvolvida pelos mesmos.

\begin{tabular}{|c|c|c|c|c|c|}
\hline Variáveis & Categorias & $\mathbf{n}$ & Diurno & Noturno & Desistentes \\
\hline \multirow[t]{4}{*}{ Grau de instrução paterno } & Ensino Fundamental & 16 & 4 & 11 & 1 \\
\hline & Ensino Médio & 18 & 4 & 13 & 1 \\
\hline & Ensino Superior & 35 & 14 & 21 & 0 \\
\hline & Não sei & 3 & 0 & 3 & 0 \\
\hline Total & & 72 & 22 & 48 & 2 \\
\hline \multirow[t]{4}{*}{ Ocupação paterna } & $\begin{array}{l}\text { Profissional liberal ou atividade profissional com exigência } \\
\text { formativa elevada. } \\
\text { Serviços administrativos, comércio, serviços técnicos e demais }\end{array}$ & 34 & 12 & 22 & 0 \\
\hline & $\begin{array}{l}\text { ocupações que exigem formação escolar mediana. } \\
\text { Trabalho manual, produção de bens e serviços industriais e }\end{array}$ & 14 & 5 & 9 & 0 \\
\hline & atividades profissionais que exigem baixa exigência formativa. & 16 & 2 & 13 & 1 \\
\hline & 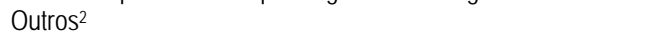 & 7 & 3 & 4 & 0 \\
\hline Total & & 71 & 22 & 48 & 1 \\
\hline \multirow[t]{3}{*}{ Grau de instrução materno } & Ensino Fundamental & 18 & 3 & 14 & 1 \\
\hline & Ensino Médio & 23 & 9 & 14 & 0 \\
\hline & Ensino Superior & 31 & 10 & 20 & 1 \\
\hline Total & & 72 & 22 & 48 & 2 \\
\hline \multirow[t]{3}{*}{ Ocupação materna } & $\begin{array}{l}\text { Profissional liberal ou atividade profissional com exigência } \\
\text { formativa elevada. }\end{array}$ & 27 & 9 & 17 & 1 \\
\hline & $\begin{array}{l}\text { Serviços administrativos, comércio, serviços técnicos e demais } \\
\text { ocupações que exigem formação escolar mediana. }\end{array}$ & 12 & 2 & 10 & 0 \\
\hline & $\begin{array}{l}\text { Trabalho manual, produção de bens e serviços industriais e } \\
\text { atividades profissionais que exigem baixa exigência formativa. }\end{array}$ & 33 & 11 & 21 & 1 \\
\hline Total & & 72 & 22 & 48 & 2 \\
\hline
\end{tabular}

Quanto aos rendimentos familiares, observa-se na Tabela 5.7 que, no período diurno, há um número levemente superior de respondentes com renda familiar per capita acima de dois

\footnotetext{
${ }^{2} \mathrm{O}$ item "Outros" foi aqui utilizado para designar os registros imprecisos realizados pelos respondentes, que impediram a clara identificação da ocupação desempenhada.
} 
salários mínimos ${ }^{3}$ (12/21) com relação aos respondentes cuja renda situa-se abaixo desse mesmo valor (9/21). Por outro lado, no período noturno, essa tendência se inverte: há mais alunos cuja renda familiar per capita é menor do que dois salários (26/48), quando comparada a rendas acima de dois salários (22/48). Se a divisão dos ganhos for ainda mais detalhada (Gráfico 5.1), percebe-se que as famílias com renda mais elevada abrangem os alunos do período diurno, uma vez que 5/21 apresentaram proventos familiares acima de 4 salários, ao passo que este número é de 6/48 no período noturno, valor proporcionalmente inferior.

\section{Tabela 5.7 - Distribuição da renda familiar per capita mensal entre os respondentes da FEUSP.}

\begin{tabular}{llllll}
\hline Variáveis & Categorias & $\mathbf{n}$ & Diurno & Noturno & Desistentes \\
\hline Renda familiar per capita & Até 1 s.m. & 21 & 6 & 11 & 4 \\
& 1 até 2 s.m. & 18 & 3 & 15 & 0 \\
& 2 até 4 s.m. & 24 & 7 & 16 & 1 \\
Total & Mais de 4 s.m. & 11 & 5 & 6 & 0 \\
& & 74 & 21 & 48 & 5 \\
\hline
\end{tabular}

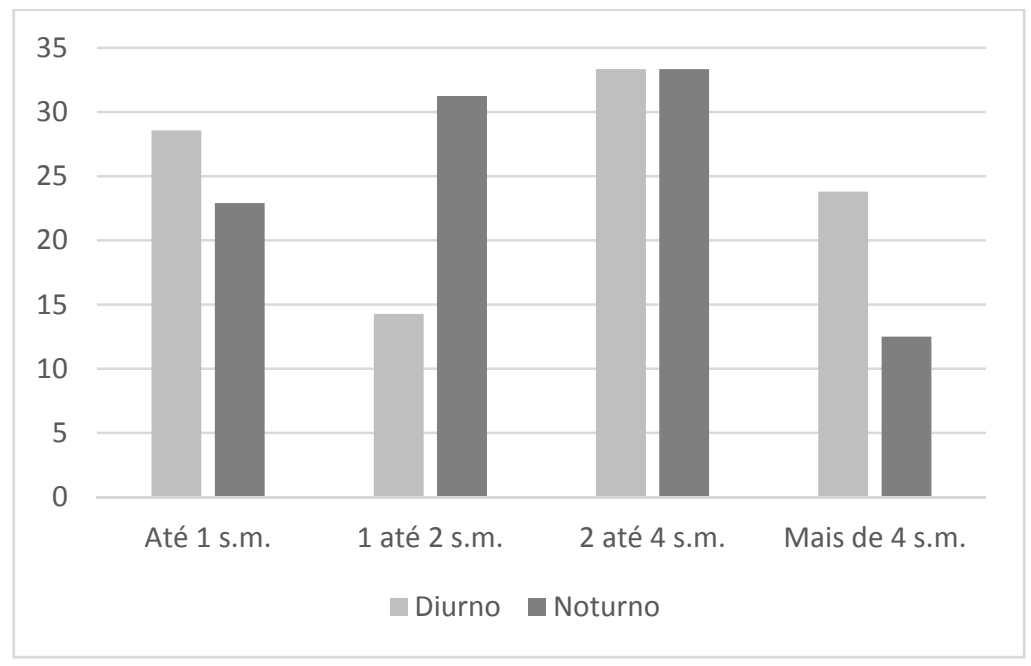

\section{Gráfico 5.1 - Apresentação gráfica da distribuição da renda familiar per capita mensal entre os turnos - FEUSP ${ }^{4}$.}

A respeito das atividades ocupacionais desenvolvidas pelos respondentes, verificou-se através da Tabela 5.8 que uma parte significativa dos alunos exercia, no último ano do curso, algum tipo de trabalho remunerado associado à área educacional. A maior parcela dos

\footnotetext{
${ }^{3}$ Para fins de cálculo da renda familiar deve-se considerar o valor padrão do salário mínimo referente ao ano de 2013 , momento em que o levantamento de dados foi realizado, definido em $\mathrm{R} \$ 678,00$.

${ }^{4}$ Valores normalizados na base 100 para permitir comparação direta.
} 
estudantes desempenhava a função de estagiário, seguido pelas atividades de docência, sendo esta última pouco mais frequente no período vespertino, ao passo que, no período noturno, também se fez presente os alunos que atuavam nas tarefas administrativas escolares. Os respondentes tenderam a realizar seus estágios não obrigatórios em instituições particulares, geralmente em escolas reconhecidas e voltadas para o atendimento de um público mais elitizado, tais como: Colégio Albert Sabin; Colégio Dante Alighieri; Colégio Equipe; Colégio Móbile; Colégio Visconde de Porto Seguro; Escola da Vila; Escola Maternal e Infantil Hebraica e Escola Pueri Domus. O tempo de dedicação ao trabalho mais recorrente no período vespertino foi o parcial, enquanto no período noturno um número equilibrado de alunos trabalhavam em jornadas parciais e integrais. Em termos de remuneração, a faixa mais comum de ganhos no período vespertino situou-se entre 1 e 2 salários mínimos, enquanto no período noturno os rendimentos tenderam a ser progressivamente mais elevados, havendo uma clara associação entre os mesmos e a jornada integral de trabalho.

Tabela 5.8 - Distribuição dos respondentes FEUSP quanto à atividade ocupacional, rendimentos e regime de trabalho durante a graduação.

\begin{tabular}{|c|c|c|c|c|c|}
\hline Variáveis & Categorias & $\mathrm{n}$ & Diurno & Noturno & Desistentes \\
\hline \multirow[t]{2}{*}{ Trabalho no último ano do curso } & Sim & 53 & 16 & 36 & 1 \\
\hline & Não & 18 & 6 & 12 & 0 \\
\hline Total & & 71 & 22 & 48 & 1 \\
\hline \multirow[t]{5}{*}{ Ocupação } & Atividades não educacionais & 10 & 4 & 6 & 0 \\
\hline & Docência & 13 & 4 & 8 & 1 \\
\hline & Estágio & 19 & 7 & 12 & 0 \\
\hline & Iniciação científica & 3 & 1 & 2 & 0 \\
\hline & Trabalho administrativo em escola & 8 & 0 & 8 & 0 \\
\hline Total & & 53 & 16 & 36 & 1 \\
\hline \multirow[t]{8}{*}{ Rendimentos } & Até 1 s.m. & 3 & 1 & 2 & 0 \\
\hline & Entre 1 e 2 s.m. & 22 & 9 & 13 & 0 \\
\hline & Entre 2 e 3 s.m. & 14 & 4 & 10 & 0 \\
\hline & Entre 3 e 5 s.m. & 9 & 2 & 6 & 1 \\
\hline & Entre 5 e 7 s.m. & 3 & 0 & 3 & 0 \\
\hline & Entre 7 a 10 s.m. & 0 & 0 & 0 & 0 \\
\hline & Entre 10 e 14 s.m. & 1 & 0 & 1 & 0 \\
\hline & Acima de 14 s.m. & 1 & 0 & 1 & 0 \\
\hline Total & & 53 & 16 & 36 & 1 \\
\hline \multirow[t]{5}{*}{ Rendimentos professoras } & Até 1 s.m. & 2 & 1 & 1 & 0 \\
\hline & Entre 1 e 2 s.m. & 0 & 0 & 0 & 0 \\
\hline & Entre 2 e 3 s.m. & 4 & 2 & 2 & 0 \\
\hline & Entre 3 e 5 s.m. & 5 & 1 & 3 & 1 \\
\hline & Entre 5 e 7 s.m. & 2 & 0 & 2 & 0 \\
\hline Total & & 13 & 4 & 8 & 1 \\
\hline \multirow[t]{4}{*}{ Rendimentos estagiárias } & Até 1 s.m. & 1 & 0 & 1 & 0 \\
\hline & Entre 1 e 2 s.m. & 13 & 6 & 7 & 0 \\
\hline & Entre 2 e 3 s.m. & 4 & 1 & 3 & 0 \\
\hline & Entre 3 e 5 s.m. & 1 & 0 & 1 & 0 \\
\hline Total & & 19 & 7 & 12 & 0 \\
\hline \multirow[t]{2}{*}{ Regime de trabalho } & Parcial & 31 & 12 & 19 & 0 \\
\hline & Integral & 21 & 4 & 17 & 0 \\
\hline Total & & 52 & 16 & 36 & 0 \\
\hline
\end{tabular}


A esse respeito, convém mencionar o estudo realizado por Ishii, Krasilchik e Leite (2014) que investigou o perfil dos ingressantes dos cursos de Engenharia, Odontologia e Pedagogia da Universidade de São Paulo, a partir do questionário de avaliação socioeconômica apresentado no manual da FUVEST nos anos de 2007, 2008 e 2009. A expectativa dos autores era verificar a existência de perfis distintos entre os alunos de cada um desses cursos, desfazendo a percepção que tende a homogeneizar os estudantes da USP, como se todos os alunos, independente do curso, fossem iguais. Como resultado os pesquisadores identificaram que os estudantes de engenharia e odontologia (modalidade integral), apresentam condições culturais e econômicas mais privilegiadas. Por outro lado, os alunos ingressantes no curso de Odontologia noturno possuem um perfil socioeconômico próximo ao dos alunos matriculados no curso de Pedagogia. Estes últimos são os que apresentaram os índices menos favoráveis no que se refere à posse de capital econômico e cultural, sendo caracterizados pela idade mais elevada ao ingressar na universidade (média de 22 anos), além de serem egressos de escolas públicas. Em termos familiares, os pais destes estudantes possuem como grau mais elevado de formação o ensino fundamental e médio, enquanto a renda mensal varia de um a cinco salários mínimos. Por fim, estes alunos se destacam pela maior necessidade em dividir seu tempo entre trabalho e estudo, principalmente os cursistas do período noturno. Os alunos de Odontologia integral e engenharia, contrariamente, ingressaram na graduação com 17 ou 18 anos; são egressos de escolas particulares e seus pais possuem o ensino superior como grau de formação mais representativo. Estes alunos não trabalham e a renda familiar atinge uma faixa de até catorze salários mínimos.

A condição desprivilegiada dos alunos da Pedagogia também foi identificada por Setton (1999) ao investigar a hierarquização existente nos cursos de Humanidades da USP. A análise sociocultural e econômica dos alunos indicou a existência de diferenças que permitiu à autora classificar os cursos a partir de três categorias: seletos, intermediários e populares. Nos cursos seletos os alunos se caracterizam pela posse elevada dos três tipos de capital (cultural, econômico e social). Essa característica termina por conduzi-los a carreiras mais concorridas no vestibular e que oferecem boas perspectivas de retorno financeiro e reconhecimento social. Neste caso encontram-se, por exemplo, os cursos de Direito, Administração e Arquitetura. Na caracterização dos cursos denominados como intermediários os alunos se diferenciam pela posse razoavelmente distintiva de capital econômico e social ou exclusivamente pela detenção de um elevado nível de capital cultural. Alguns dos cursos presentes neste grupo são Psicologia, Jornalismo e Contabilidade. Os cursos populares, por sua vez, são frequentados por alunos que 
possuem baixo volume em todas as modalidades de capital, ou seja, seus pais possuem nível de instrução reduzido, as ocupações profissionais dos mesmos são modestas, assim como a renda familiar. Estes estudantes também possuem uma trajetória escolar caracterizada pela formação em escolas públicas, além de não terem tido a oportunidade de complementar sua instrução por meio de cursos extracurriculares. Neste último agrupamento encontram-se os cursos de Biblioteconomia e os demais que oferecem a habilitação em licenciatura: Letras, Geografia, Filosofia, História, Ciências Sociais e Pedagogia.

Leme (2012), em sua dissertação de mestrado, também realizou um movimento de comparação de cursos com perfis distintos de alunado. Em seu estudo, foram caracterizados os ingressantes do ano de 2010 nos cursos de Medicina, licenciatura em Física, Matemática e Pedagogia da USP. Considerando seus resultados, identificou-se, entre os estudantes do curso de Medicina, um perfil muito próximo ao dos alunos de Odontologia integral e Engenharia, tal como foi delineado por Ishii, Krasilchik e Leite (2014). Já em meio aos cursos de licenciatura, o perfil dos alunos assumiu uma caracterização análoga à estabelecida por Setton (1999) para os cursos por ela definidos como "populares". Entretanto, Leme (2012) enfatizou em seu trabalho que o curso de Pedagogia, apesar de acolher alunos pouco privilegiados, reuniu estudantes que usufruíam de uma condição levemente superior em relação aos outros dois cursos de licenciatura investigados. Assim, o poder de compra das famílias dos alunos de Pedagogia era superior ao dos demais, havendo entre eles mais alunos que estudaram em instituições particulares de ensino. O nível de escolaridade dos pais dos ingressantes da Pedagogia também era mais elevado que o dos alunos das outras licenciaturas, enquanto os mesmos desempenhavam em menor número ocupações relacionadas ao trabalho manual.

A partir dos resultados obtidos nas pesquisas anteriormente citadas, pode-se afirmar que, de modo geral, os cursos de maior prestígio da USP são identificados como os mais concorridos no vestibular. Estes tendem a atrair para si estudantes egressos de escolas particulares, cuja formação não experimentou nenhum tipo de interrupção, favorecendo a rápida admissão no ensino superior, justificando, assim, a baixa idade de seus ingressantes. Em relação à origem social dos alunos, nota-se que suas famílias possuem rendimentos elevados, seus pais são geralmente portadores do diploma universitário e oferecem aos seus filhos o respaldo necessário para que se dediquem integralmente aos estudos. Consequentemente, é possível concluir, tal como afirmou Pereira (2006, p. 88), que "a pouca idade dos alunos, associada a outras condições sociais, econômicas e culturais, constitui fator de aprovação nos cursos mais disputados do vestibular". Por outro lado, os cursos menos prestigiosos apresentam baixa 
demanda e são menos seletivos, atraindo para si cursistas portadores de uma condição socioeconômica e cultural menos favorecida, estando nesta condição os estudantes do curso de Pedagogia (SCHWARTZMAN e CASTRO, 1992).

Com base em levantamento realizado no endereço eletrônico da Fundação Universitária para o Vestibular (FUVEST), a respeito das notas de corte implementadas no curso de Pedagogia nos últimos cinco anos, apresentadas na Tabela 5.9, constatou-se a permanência da mesma condição observada por Leme (2012) em relação aos ingressantes de 2010: a admissão nesta carreira exige baixa pontuação por parte dos candidatos, sendo ela uma das menores do campus de São Paulo, com exceção dos cursos oferecidos pela USP Leste. A tabela apresentada a seguir, organizada tendo como objetivo listar os cursos que contaram com nota de corte igual ou inferior ao curso de Pedagogia, demonstra que, de fato, esta formação figura entre as menos seletivas da universidade.

\section{Tabela 5.9 - Cursos com menor nota de corte no vestibular da FUVEST para carreiras oferecidas no campus de São Paulo. 5}

\begin{tabular}{lccccc}
\hline & $\mathbf{2 0 1 1}$ & $\mathbf{2 0 1 2}$ & $\mathbf{2 0 1 3}$ & $\mathbf{2 0 1 4}$ & $\mathbf{2 0 1 5}$ \\
\hline Pedagogia & 24 & 33 & 33 & 33 & 36 \\
Letras & 24 & - & - & - & - \\
Licenciatura em Educomunicação & - & - & - & 32 & 36 \\
Licenciatura em Geociências e Ed. ambiental & 22 & 27 & 27 & 28 & 27 \\
Licenciatura em Matemática e Física & 22 & 27 & 27 & 33 & 31 \\
Música ECA & 24 & 33 & - & 32 & - \\
Saúde Pública & - & 27 & - & 27 & - \\
\hline
\end{tabular}

Fonte: Elaborado pela autora

A relação existente entre as condições socioeconômicas e culturais, idade e o curso de graduação a ser seguido pelos candidatos se fez claramente presente entre os respondentes aqui investigados. Iniciando pelos aspectos etários, apesar da média de idade dos alunos ser elevada, indicando o ingresso tardio na graduação, pesa o fato de praticamente metade dos respondentes

\footnotetext{
${ }^{5}$ Nessa tabela foram apresentadas somente as notas de corte iguais ou inferiores à estipulada para o curso de Pedagogia.

No vestibular de 2011 e 2012 a vestibular da FUVEST contou com 89 questões. A partir do ano de 2013 a prova passou a ser composta por 90 questões.

Nesses mesmos vestibulares, os três cursos com nota de corte mais elevada na cidade de São Paulo foram Medicina (2011 - 70 pontos; 2012 - 73 pontos; 2013 - 73 pontos; 2014 - 70 pontos; 2015 - 72 pontos); Curso Superior do Audiovisual (2011 - 59 pontos; 2012 - 61 pontos; 2013 - 60 pontos; 2014 - 59 pontos; $2015-60$ pontos) e Engenharia na Escola Politécnica (2011 - 58 pontos; 2012 - 63 pontos; 2013 - 61 pontos; 2014 - 60 pontos; $2015-61$ pontos).
} 
(35/73) já terem começado outro curso antes de procurarem pela formação em Pedagogia. Dados estatísticos publicados na página da FUVEST demonstram ser esta uma tendência do curso, que não se repete na mesma proporção entre as graduações reconhecidas como mais seletivas e que se destacam pela pouca idade dos seus alunos ingressantes. No Gráfico 5.2, é possível observar que mais da metade dos alunos que cursaram Pedagogia entre 2011 e 2015 já haviam iniciado ou concluído outra graduação, característica destoante em relação aos cursos de Engenharia, Medicina e Direito, detentores de uma proporção muito menor de alunos que vivenciaram este processo (entre 10 e $27 \%$ ). A constância das porcentagens analisadas durante o passar dos anos comprova ser esta uma tendência persistente no tempo e não apenas um caso isolado. Assim, a idade dos alunos do curso de Pedagogia não pode ser analisada sem considerar o número de cursistas que possuem em sua trajetória formativa a passagem por outros cursos de graduação, sendo esta uma característica já observada por Souza e Oliveira (1998) em investigação desenvolvida na década de 1990.

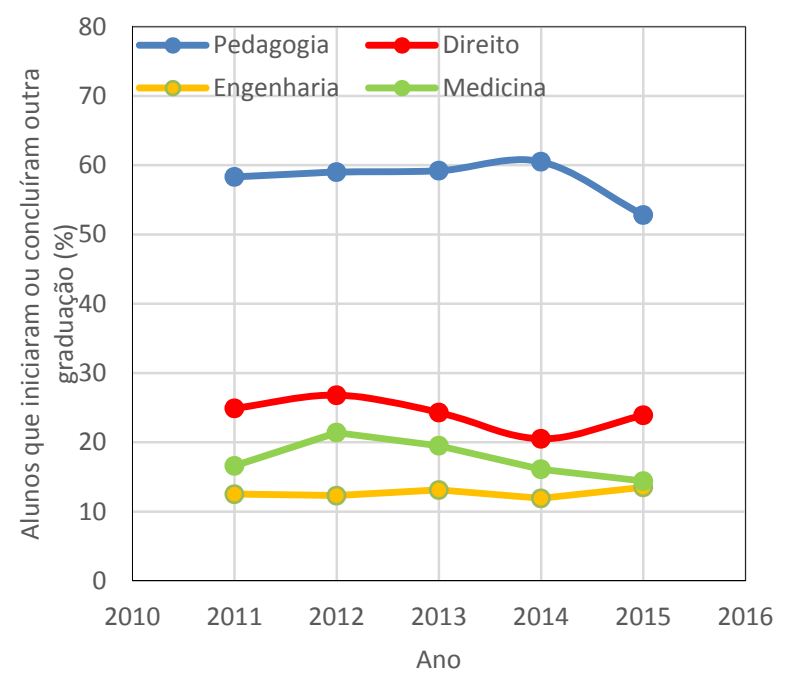

Gráfico 5.2 - Evolução do percentual de alunos que iniciaram ou concluíram outra graduação nos cursos de Pedagogia, Direito, Engenharia e Medicina (Fonte: Elaborado pela autora).

Quanto ao processo de escolarização vivenciado anteriormente ao ingresso na universidade, observou-se entre os respondentes uma divisão equilibrada no período noturno, durante o ensino médio, da formação em instituições públicas e privadas, enquanto no período vespertino prevaleceu a formação nas instituições particulares. A proporção equilibrada entre os egressos das escolas públicas e particulares em meio aos alunos da Pedagogia da USP de São Paulo já havia sido identificada por Souza e Oliveira (1998) entre os ingressantes do ano

\footnotetext{
${ }^{6}$ Os dados utilizados se referem aos alunos matriculados nos cursos oferecidos no campus de São Paulo.
} 
de 1993. Leme (2012), por sua vez, verificou, entre os ingressantes de 2010, que a proporção de alunos no curso de Pedagogia que haviam estudado em escolas particulares era levemente superior em relação aos alunos dos cursos de licenciatura em Matemática e Física, enquanto no curso de Medicina - carreira mais concorrida no vestibular da FUVEST - a formação se dava predominantemente nas instituições privadas. Tendo em vista a certificação deste padrão observado por Leme (2012), foi realizado um levantamento em meio aos dados estatísticos da FUVEST a respeito do percurso formativo dos alunos dos cursos de medicina e licenciatura em Pedagogia, Matemática e Física durante sua escolarização no ensino médio, entre os anos de 2011 a 2015. Como resultado, foi possível constatar uma tendência do curso de Pedagogia em atrair alunos cuja trajetória escolar é moderadamente distribuída pela passagem em escolas públicas e particulares, diferenciando-se do curso de licenciatura em Matemática e Física também situados entre as carreiras menos concorridas - mas que se distinguem por uma presença mais constante da formação de seus ingressantes em escolas públicas, tal como ilustram os Gráficos 5.3.a e 5.3.b:
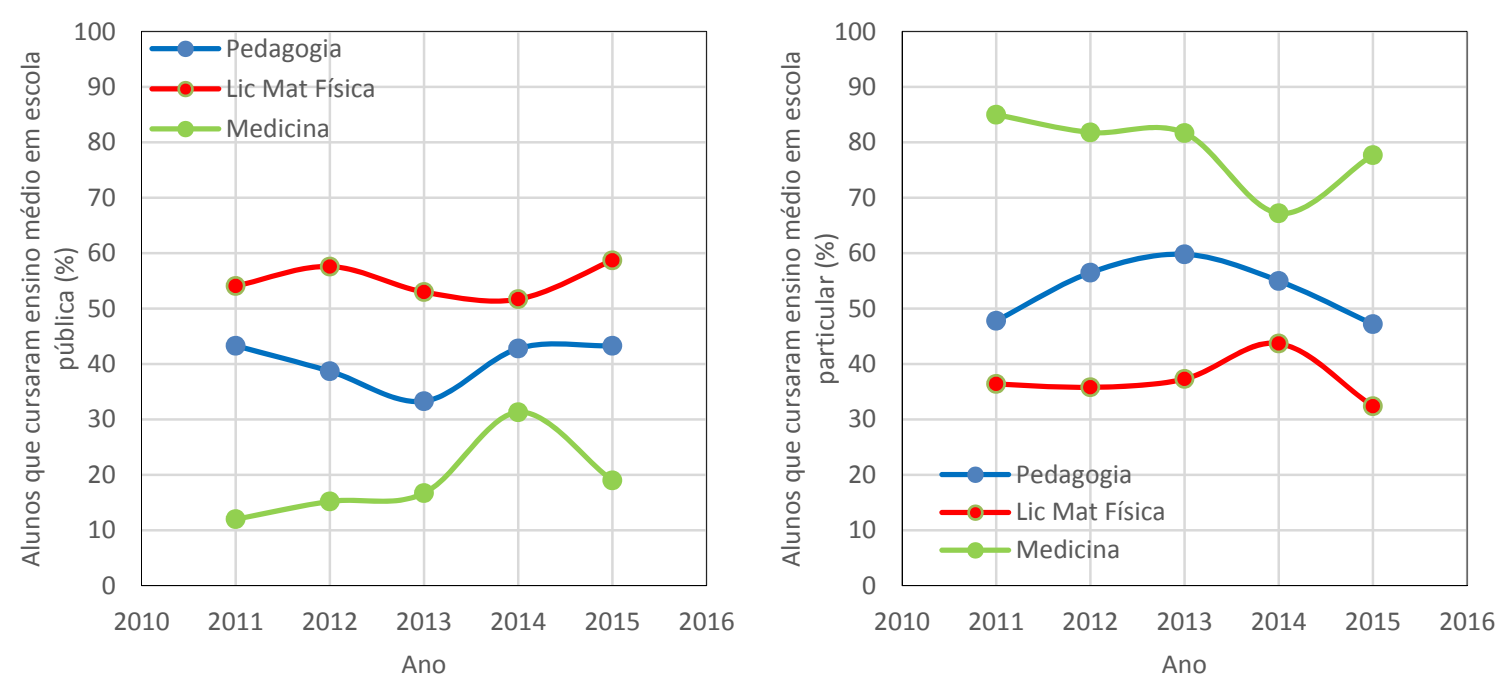

Gráfico 5.3 - Evolução do percentual de alunos ingressantes nos cursos de Medicina e licenciatura em Pedagogia, Matemática e Física de acordo com a rede de ensino em que cursaram o ensino médio (2011-2015): a) rede pública; b) rede particular (Fonte: Elaborado pela autora)

Considerando o grau de escolaridade dos pais dos respondentes desta investigação, obteve-se a informação que o nível superior foi o mais frequente nos dois turnos, porém o período vespertino se destacou pelo número mais elevado de pais universitários. Ainda assim, praticamente metade dos alunos superou o nível de escolaridade paterno (32/67), enquanto mais da metade superou o nível de formação de suas mães (40/70). O índice de escolaridade dos pais aqui obtido mostrou-se mais elevado em relação ao identificado por Souza e Oliveira (1998) 
em 1993, quando somente $17 \%$ dos pais e $8 \%$ das mães possuíam o terceiro grau concluído, ao mesmo tempo que se aproximou novamente dos índices observados por Leme $(2012$, p. 99) em 2010: "Na Pedagogia, metade do grupo superou a escolaridade dos pais ao ingressar no ensino superior." A autora ainda identificou que o nível de escolaridade familiar dos alunos da Pedagogia era superior em relação aos pais dos alunos do curso de licenciatura em Matemática e Física, característica que se manteve em novo levantamento realizado a partir dos dados da FUVEST com as turmas de ingressantes posteriores ao ano de 2010, dos cursos de Medicina e licenciatura em Pedagogia, Matemática e Física, cujos dados são apresentados nos Gráficos

\section{4 e 5.5:}
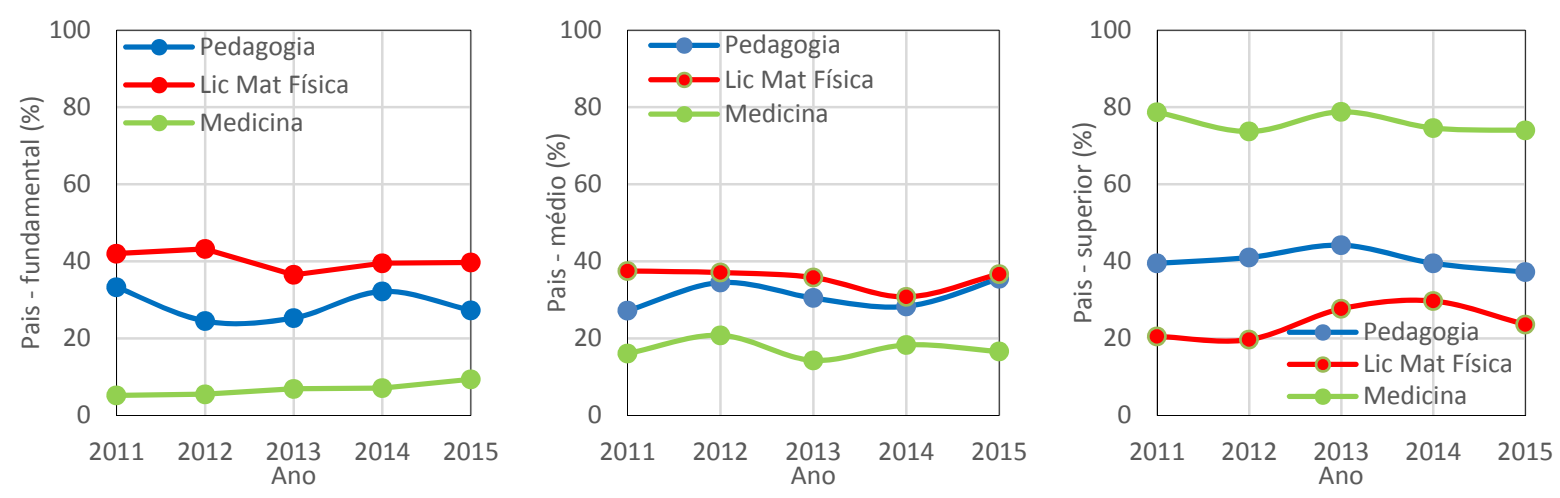

Gráfico 5.4 - Evolução percentual do grau de escolaridade dos pais dos cursistas ingressantes nas graduações de Medicina e licenciatura em Pedagogia, Matemática e Física (2011-2015): a) pais que cursaram ensino fundamental; b) pais que cursaram ensino médio; c) pais que cursaram ensino superior (Fonte: Elaborado pela autora).
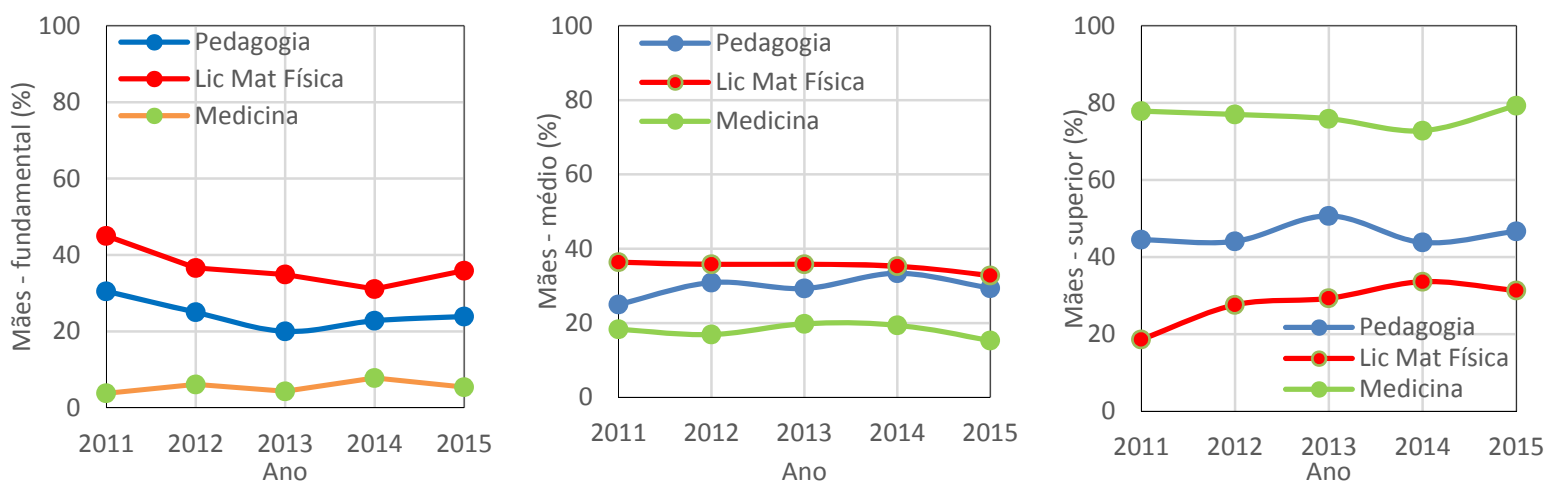

Gráfico 5.5 - Evolução percentual do grau de escolaridade das mães dos cursistas ingressantes nas graduações de Medicina e licenciatura em Pedagogia, Matemática e Física (2011-2015): a) mães que cursaram ensino fundamental; b) mães que cursaram ensino médio; c) mães que cursaram ensino superior (Fonte: Elaborado pela autora). 
A situação econômica das famílias dos estudantes, por sua vez, demonstra a permanência do distanciamento observado entre as licenciaturas em Pedagogia, Matemática e Física, além do curso de Medicina. Tal como Leme (2012) apontou, os alunos do curso de Medicina pertencem a famílias com um poder de compra significativamente elevado e distinto em relação aos cursos de licenciatura. Entre estes últimos, porém, os estudantes de Pedagogia apresentam condições socioeconômicas mais elevadas. Dados estatísticos da FUVEST a respeito da renda familiar dos últimos cinco anos (2011-2015) ilustram que a faixa de ganhos comum aos três cursos varia de 5 a 10 salários mínimos, porém, mais de cinquenta por cento dos alunos do curso de Medicina pertencem a famílias cujos ganhos superam os 10 salários mínimos. Os alunos de licenciatura em Matemática e Física, por sua vez, destacam-se pelo fato de possuírem o maior número de famílias inseridas nas faixas de renda mais baixas, enquanto os alunos da Pedagogia tendem a níveis de renda familiar superiores em relação a estes últimos, tal como ilustram os Gráficos 5.6 e 5.7:
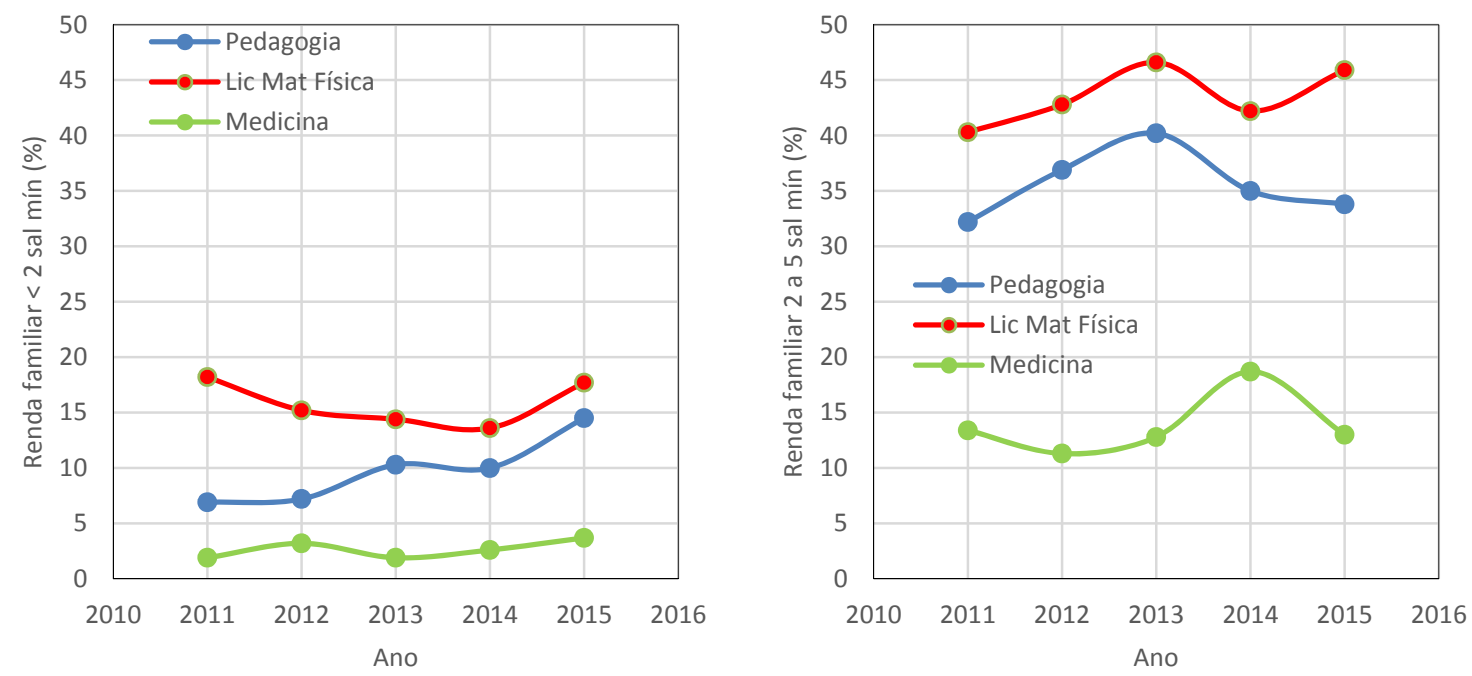

Gráfico 5.6 - Evolução percentual da renda familiar mensal dos cursistas ingressantes nas graduações de Medicina e licenciatura em Pedagogia, Matemática e Física (20112015): a) < 2 salários mínimos; b) 2 a 5 salários mínimos (Fonte: Elaborado pela autora). 

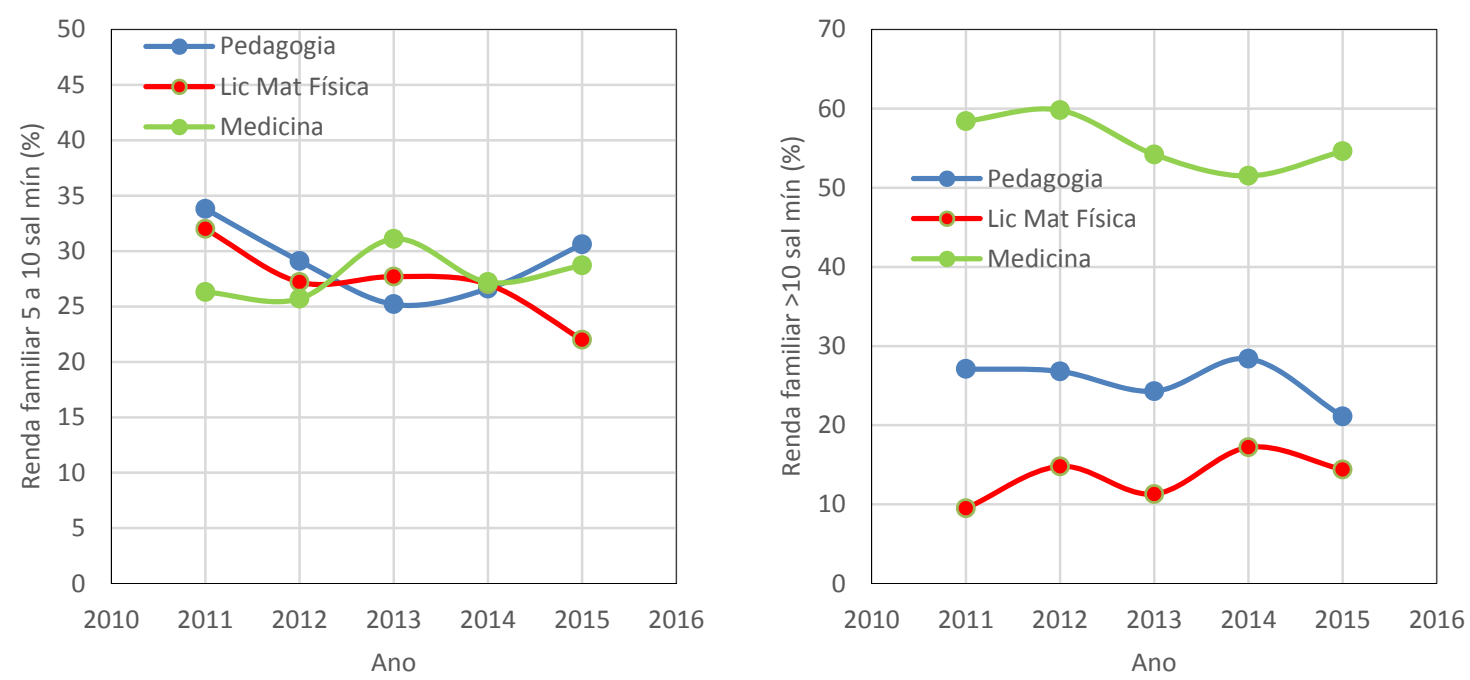

Gráfico 5.7 - Evolução percentual da renda familiar mensal dos cursistas ingressantes nas graduações de Medicina e licenciatura em Pedagogia, Matemática e Física (20112015): a) 5 a 10 salários mínimos; b) > de 10 salários mínimos (Fonte: Elaborado pela autora).

O percurso escolar dos alunos da Pedagogia, bem como o grau de escolaridade e renda familiar indicam que este grupo de estudantes não conta com os mesmos privilégios socioeconômicos e culturais partilhados pelos alunos do curso de Medicina, reconhecidos como portadores das condições sociais mais privilegiadas entre os cursistas da Universidade de São Paulo. Por outro lado, a produção de dados sucessivos e recentes, comparando os cursos de licenciatura em Pedagogia e Matemática/Física, a partir da proposta de pesquisa formulada por Leme (2012), forneceu elementos que validam a constatação da existência de variações internas no perfil estudantil dos cursos classificados como "populares". Ou seja, enquanto Ishii, Krasilchik e Leite (2014) e Setton (1999) procuravam desnaturalizar a homogeneização do suposto "aluno USP" por meio do estabelecimento de diferentes perfis estudantis relacionados aos cursos oferecidos na universidade, foi identificado que até mesmo entre cursos portadores de objetivos formativos próximos, no caso os cursos de formação de professores, há multiplicidade na distribuição do capital econômico, social e cultural que reproduz no meio universitário as diferenças de posições ocupadas pelos agentes no espaço social. $\mathrm{Na}$ hierarquização dos cursos de licenciatura (Pedagogia, Matemática e Física), compreendidos como carreiras que acolhem um perfil menos privilegiado entre o alunado da universidade, o curso de Pedagogia da USP de São Paulo ocupa uma posição mediana, que tende a se tornar mais elevada ao se considerar os respondentes do período vespertino. 


\subsection{A POBREZA DAS PRÁTICAS CULTURAIS E A POSSE ENFRAQUECIDA DAS DISPOSIÇÕES NECESSÁRIAS PARA A CONSOLIDAÇÃO DE JOGADORES RESISTENTES}

O que os estóicos chamavam de ataraxia é indiferença ou serenidade da alma, desprendimento, não desinteresse. Assim, a illusio é o oposto da ataraxia, é estar envolvido, é investir nos alvos que existem em certo jogo, por efeito da concorrência, e que apenas existem para as pessoas que, presas ao jogo, e tendo as disposições para reconhecer os alvos que aí estão em jogo, estão prontas a morrer pelos alvos que, inversamente, parecem desprovidos de interesse do ponto de vista daquele que não está preso a este jogo, e que o deixa indiferente. (BOURDIEU, 1996, p. 140)

O estudo das atividades culturais desenvolvidas pelos respondentes do curso de Pedagogia da USP de São Paulo (Tabela 5.10) identificou que as mais frequentemente praticadas são: navegar pela internet; ler; ouvir música e descansar. A assistência a TV e os cuidados com a casa também contaram com uma adesão significativa, porém, em termos de participação, envolveram pouco menos da metade dos alunos investigados.

Tabela 5.10 - Atividades mais frequentemente realizadas no tempo livre pelos respondentes da FEUSP.

\begin{tabular}{|c|c|c|c|c|}
\hline Variáveis & Categorias & $\mathrm{n}$ & Diurno & Noturno \\
\hline \multirow[t]{4}{*}{ Cuidados com a casa } & Frequentemente & 27 & 8 & 19 \\
\hline & Ocasionalmente & 19 & 3 & 16 \\
\hline & Raramente & 6 & 3 & 3 \\
\hline & Nunca & 3 & 1 & 2 \\
\hline Total & & 55 & 15 & 40 \\
\hline \multirow[t]{4}{*}{ Descansar } & Frequentemente & 28 & 9 & 19 \\
\hline & Ocasionalmente & 15 & 4 & 11 \\
\hline & Raramente & 11 & 1 & 10 \\
\hline & Nunca & 2 & 1 & 1 \\
\hline Total & & 56 & 15 & 41 \\
\hline \multirow[t]{2}{*}{ Internet } & Frequentemente & 52 & 15 & 37 \\
\hline & Raramente & 1 & 0 & 1 \\
\hline Total & & 53 & 15 & 38 \\
\hline \multirow[t]{3}{*}{ Leituras } & Frequentemente & 43 & 10 & 33 \\
\hline & Ocasionalmente & 10 & 4 & 6 \\
\hline & Raramente & 3 & 1 & 2 \\
\hline Total & & 56 & 15 & 41 \\
\hline \multirow[t]{3}{*}{ Ouvir música } & Frequentemente & 41 & 13 & 28 \\
\hline & Ocasionalmente & 11 & 1 & 10 \\
\hline & Raramente & 4 & 1 & 3 \\
\hline Total & & 56 & 15 & 41 \\
\hline \multirow[t]{4}{*}{ Televisão } & Frequentemente & 27 & 7 & 20 \\
\hline & Ocasionalmente & 12 & 3 & 9 \\
\hline & Raramente & 16 & 5 & 11 \\
\hline & Nunca & 1 & 0 & 1 \\
\hline Total & & 56 & 15 & 41 \\
\hline
\end{tabular}

Atividade de destaque, o uso frequente da internet foi assinalado por praticamente a totalidade dos respondentes. $\mathrm{O}$ acesso domiciliar consistiu no local de consulta mais comum 
entre os estudantes (34/53), seguido pelos aparelhos eletrônicos móveis (12/53), enquanto somente sete alunos afirmaram utilizar a internet com mais frequência a partir de espaços públicos como o local de trabalho (4/53) e a universidade (3/53). A finalidade do acesso à internet para mais da metade dos alunos envolveu a comunicação com outras pessoas (29/53), seja por meio da troca de e-mails ou uso das redes sociais. Uma pequena parcela de alunos, mas não desprezível, afirmou utilizar a internet para fins de estudo e trabalho (13/53), ao passo que o menor emprego desse recurso consistiu na consulta a sites de notícias (2/53).

A prática da leitura durante o tempo livre foi indicada como a segunda atividade mais realizada pelos respondentes. Entre a leitura de livros, revistas e jornais, os alunos demonstraram uma clara predileção pelos primeiros. Em meio a cinquenta e cinco respondentes, praticamente metade dos alunos afirmou ler livros com uma frequência elevada (27/55), contudo, três desses estudantes não souberam informar o nome do último livro tomado como objeto de sua atenção. Num total de quarenta e oito títulos citados (Quadro 5.1), foi possível observar uma recorrência maior dos romances estrangeiros que contaram com a indicação de vinte e cinco obras, com forte presença de best-sellers como Game of Thrones (George R. R. Martin), Jogos Vorazes (Suzanne Collins), As Crônicas de Nárnia (Clive S. Lewis), A menina que roubava livros (Markus Zusak), O Hobbit (John Ronald R. Tolkien), entre outros que, além do sucesso de vendas, possuem em comum o fato de terem sido adaptados para o cinema ou séries televisivas. Obras clássicas da literatura internacional foram citadas, porém de modo menos recorrente, tais como 1984, A revolução dos bichos (George Orwell) e As aventuras de Pinóquio (Carlo Collodi), do mesmo modo que romances elaborados por escritores proeminentes como Umberto Eco (O cemitério de Praga), William Golding (Senhor das moscas), Jane Austen (Emma), Ray Bradbury (Fahrenheit 451) e Jens P. Jacobsen (Niels Lyhne). Entre os romances nacionais foram citados nomes elementares da literatura brasileira (geralmente indicados para o vestibular) como Machado de Assis, Aluísio Azevedo e Clarice Lispector, além de autores contemporâneos que se tornaram conhecidos, seja pela elaboração de obras que contaram com grande número de vendas como Martha Medeiros, ou pelo valor literário de sua produção, caso de Milton Hatoum (Relato de um certo oriente). 
Quadro 5.1 - Listagem dos livros lidos recentemente pelos respondentes da FEUSP.

\begin{tabular}{|c|c|}
\hline Variáveis & Categorias \\
\hline Livros estrangeiros & $\begin{array}{l}1984 \text { (George Orwell) } \\
\text { A menina que roubava livros (Markus Zusak) (2) } \\
\text { A revolução dos bichos (George Orwell) } \\
\text { As aventuras de Pinóquio (Carlo Collodi) } \\
\text { As Crônicas de Nárnia (Clive S. Lewis) } \\
\text { Emma (Jane Austen) } \\
\text { Fahrenheit } 451 \text { (Ray Bradbury) } \\
\text { Game of Thrones (George R. R. Martin) (2) } \\
\text { Jogos Vorazes (Suzanne Collins) } \\
\text { Morte na mesopotâmia (Agatha Christie) } \\
\text { Niels Lyhne (Jens P. Jacobsen) } \\
\text { O beijo da mulher aranha (Manuel Puig) } \\
\text { O cemitério de Praga (Umberto Eco) } \\
\text { O Grande Gatsby (Frances S. Fitzgerald) } \\
\text { O Hobbit (J. R. R. Tolkien) } \\
\text { O livro dos abraços (Eduardo Galeano) } \\
\text { O menino do pijama listrado (John Boyne) } \\
\text { O silêncio das montanhas (Khaled Hosseini) } \\
\text { On the road (Jack Kerouac) } \\
\text { P.S. eu te amo - existem amores que duram mais que uma vida (Cecelia Ahern) } \\
\text { Pequena Abelha (Chris Cleave) } \\
\text { Senhor das moscas (William Golding) } \\
\text { The Jane Austen Book Club (Karen J. Fowler) }\end{array}$ \\
\hline Livros nacionais & $\begin{array}{l}\text { Bolinho de Chuva e outras miudezas (Paulo Netho) } \\
\text { Crocodilo Sonhador (Vanda Amorim) } \\
\text { Esaú e Jacó (Machado de Assis) } \\
\text { O cortiço (Aluísio Azevedo) } \\
\text { Relato de um certo oriente (Milton Hatoum) } \\
\text { Renato Russo - o filho da revolução (Carlos Marcelo) } \\
\text { Um lugar na janela - relatos de viagem (Martha Medeiros) } \\
\text { Uma aprendizagem ou o livro dos prazeres (Clarice Lispector) }\end{array}$ \\
\hline Educação & $\begin{array}{l}\text { A importância do ato de ler (Paulo Freire) } \\
\text { Antropolíticas da educação (Marcos F. Santos e Rogério de Almeida) } \\
\text { Didática da alfabetização (Esther P. Grossi) } \\
\text { Ei, professor (Frank Mccourt) } \\
\text { Fundamentos da Educação Infantil: enfrentando o desafio (Janet Moyles) } \\
\text { Memórias de Cibele: experiências corporais e identidade docente (Carolina Kondratiuk; Marcos } \\
\text { Neira) } \\
\text { Reflexões sobre alfabetização (Emilia Ferreiro) } \\
\text { Sucesso escolar nos meios populares (Bernard Lahire) }\end{array}$ \\
\hline Religião & $\begin{array}{l}\text { Ascese: os Salvadores de Deus (Nikos Kazantzakis) } \\
\text { Corte x namoro (Pr. Naor Pedroza) } \\
\text { Mitologia dos Orixás (Reginaldo Prandi) }\end{array}$ \\
\hline Política/Fotografia/Antropologia/Administração geral & $\begin{array}{l}\text { Por uma outra globalização (Milton Santos) } \\
\text { Fotografia e História (Boris Kossoy) } \\
\text { Cultura: um conceito antropológico (Roque de Barros Laraia) } \\
\text { O monge e o executivo: uma história sobre a essência da liderança (James C. Hunter) }\end{array}$ \\
\hline
\end{tabular}

Em menor proporção, obras especializadas também foram indicadas como objeto de leitura dos respondentes, com destaque para a recorrência das de conteúdo educacional (8/48), cujos temas mais comuns foram educação infantil e alfabetização. Livros de conteúdo político, histórico e sociológico também foram citados (4/48), assim como produções de cunho religioso (3/48), possuindo dois desses livros um discurso que aborda o tema da religião a partir das perspectivas sociológica, histórica e filosófica. 
Considerando-se a leitura de periódicos, verificou-se na Tabela 5.11 que tanto os jornais quanto as revistas são pouco consultados pelos respondentes da FEUSP, uma vez que um número elevado de alunos afirmou ler pouco ou simplesmente não utilizar esse tipo de fonte de informação.

\section{Tabela 5.11 - Frequência da leitura de revistas e jornais entre os respondentes da FEUSP.}

\begin{tabular}{lll}
\hline Variáveis & Categorias & $\mathbf{n}$ \\
\hline Revistas & Leio muito & 5 \\
& Leio regularmente & 6 \\
& Leio pouco & 33 \\
& Não leio & 10 \\
Total & & 54 \\
Jornais & Leio muito & 4 \\
& Leio regularmente & 10 \\
& Leio pouco & 28 \\
Total & Não leio & 12 \\
& & 54 \\
\hline
\end{tabular}

A respeito das revistas, dez respondentes não as leem, enquanto em meio aos alunos que afirmaram lê-las pouco ou regularmente (39), dezesseis não conseguiram indicar os títulos dos periódicos que eventualmente consultam, deixando suas respostas em branco ou oferecendo informações evasivas, tais como: "As da sala de espera"; "Científicas"; "Moda"; "Revistas de história"; “A revista do jornal de domingo". Entre os demais alunos, vinte e oito registraram os nomes das revistas que costumam ler, obtendo-se como resultado o apontamento de quarenta e cinco títulos, uma vez em que houve casos de respostas que continham mais de um registro.

A partir dos nomes das revistas e da contabilização de sua recorrência (Quadro 5.2), foi possível verificar que as mais lidas são Veja (7 citações); Nova Escola (7 citações) e Superinteressante (6 citações), publicações que ocupam os primeiros lugares em vendas na região sudeste do Brasil ${ }^{7}$. Cada uma dessas três revistas representam as principais categorias de interesse destes estudantes: em primeiro lugar se destacam as revistas que tratam de temas políticos, econômicos e culturais (15/28); em segundo lugar as publicações voltadas para a divulgação de curiosidades científicas (10/28), seguido pelas revistas especializadas em educação (9/28). Entre as revistas do primeiro grupo, há duas modalidades distintas de publicações as quais os estudantes recorrem. Por um lado, há um grupo de leitores interessados nas revistas Veja e Época, mais populares e voltadas ao grande público, enquanto outros

\footnotetext{
${ }^{7}$ De acordo com levantamento realizado pelo Instituto Verificador de Comunicação (IVC) no primeiro semestre de 2014.
} 
respondentes dirigem sua atenção para a leitura de revistas com propostas editoriais diferenciadas e que contam com menor circulação no mercado das publicações periódicas, tais como Adbusters; Caros Amigos; Carta Capital e Piauí. Caros Amigos e Carta Capital possuem em comum o caráter opinativo, associado a uma visão ideológica alinhada à esquerda, além de um conteúdo textual mais denso. Adbusters, por sua vez, é uma publicação editada por uma organização não-governamental canadense, cujo propósito é questionar o consumismo no mundo contemporâneo, dedicando-se a causas políticas e sociais. Por fim, a revista Piauí caracteriza-se pela divulgação de um jornalismo literário e ficcional, abordando um conjunto variado de temas envolvendo política, literatura, economia, artes, mídia e esportes.

Quadro 5.2 - Listagem das revistas lidas pelos respondentes da FEUSP.

\begin{tabular}{|ll|}
\hline Categorização & Títulos \\
\hline Atualidades & Época; Veja (7) \\
\hline Curiosidades culturais e científicas & Ciência Hoje; Mundo Estranho (2); Scientific American Brasil; Superinteressante (6) \\
\hline Educação & Revista Educação (2); Nova Escola (7) \\
\hline Política, economia, cultura e sociedade & Adbusters; Caros Amigos; Carta Capital (4); Piauí \\
\hline Revistas especializadas & Casa Claudia; O2 \\
\hline Revistas femininas & Gloss; Marie Claire; Tpm (2) \\
\hline Variedades & Seleções (2); Vida Simples; Ser Família, Trip \\
\hline
\end{tabular}

No que se refere aos jornais, dos quarenta e dois alunos que afirmaram realizar a leitura dos mesmos com algum tipo de frequência (muito, regular ou pouco), três não informaram o nome do jornal que costumam ler, ao mesmo tempo que quatro alunos deram respostas genéricas tais como "O jornal do trem" ou “Jornais eletrônicos”. Os demais registros efetuados, completando um número total de 49 menções, revelaram a preferência pelos jornais Folha de S. Paulo (26 citações) e O Estado de S. Paulo (12 citações), novamente identificados como os de maior circulação no estado de São Paulo. Com apenas uma única citação foram indicados dois jornais populares: Agora e o Metro, além de uma publicação especializada na divulgação de concursos públicos: a Folha Dirigida. Outros cinco alunos mencionaram publicações internacionais como os jornais espanhóis El Mundo e El País, além do The New York Times (EUA) e o La Nación ${ }^{8}$. O portal jornalístico alemão Deutsche Welle, contou com uma referência, assim como o G1, mantido pela Globo.com e dirigido pela Central Globo de Jornalismo.

\footnotetext{
${ }^{8}$ O nome do jornal La Nación possui publicações homônimas em diversos países de língua espanhola, tais como Peru, Paraguai, Chile, Argentina, entre outros. No caso da resposta oferecida pelo respondente, não é possível identificar a qual país o jornal por ele consultado se vincula.
} 
O hábito da leitura destes respondentes indicou a preferência pelos livros que proporcionam entretenimento, principalmente romances estrangeiros, com destaque para aqueles que contaram com índices elevados de vendas e grande divulgação midiática, uma vez que os mesmos foram televisionados ou adaptados para o cinema. Em termos de leitura de jornais e revistas, os resultados demonstraram que poucos alunos procuram essas fontes de informação, porém, os que costumam consultar esses materiais citaram principalmente aqueles que contam com o maior índice de vendas na região sudeste do país e são, portanto, os mais popularizados. Assim, a prática de leitura destes respondentes demonstra uma forte predisposição ao consumo de fontes massificadas, voltadas ao grande público, enquanto a indicação de livros, revistas ou jornais seletos ocorreu de forma muito reduzida. Convém observar que a leitura dos livros mais distintivos não possui associação com um determinado nível de renda e grau de instrução familiar. O mesmo, porém, não ocorre entre os leitores de revistas não comerciais e portadoras de conteúdo mais denso e jornais estrangeiros, uma vez que tais respondentes concluíram seus estudos em escolas particulares, enquanto suas famílias de origem são detentoras de elevado nível de instrução e renda.

O terceiro tipo de atividade desenvolvida pelos respondentes no seu tempo livre envolveu a escuta musical, sendo esta uma prática frequente para um número elevado de alunos (41/56). Em relação aos gêneros musicais (Tabela 5.12), mesmo diante de uma significativa dispersão das respostas, foi possível identificar a recorrência da música popular brasileira (22 citações), seguida pelo rock (10 citações) e o gospel (06 citações). Deve-se considerar também que, para além da MPB e do rock, a indicação de outros gêneros musicais distintivos (clássico, jazz, samba, tango), mesmo com baixa recorrência, superaram os estilos musicais que as pesquisas acerca das práticas culturais demonstram estarem associados às classes portadoras de menor nível de escolaridade e renda, tais como forró, gospel e sertanejo (BOTELHO e FIORE, 2005; IBOPE Media, 2013). Entretanto, o cruzamento das preferências musicais com a origem social dos respondentes indicou ausência de associação entre a posse de um gosto musical distintivo e níveis de renda e escolaridade familiar mais elevados. Por outro lado, os alunos que afirmaram sua preferência pelo gospel estão claramente associados a um percurso formativo concluído em escolas públicas, cujos pais possuem principalmente a educação básica. 
Tabela 5.12 - Distribuição dos gêneros musicais apreciados pelos respondentes da FEUSP.

\begin{tabular}{ll}
\hline Gêneros musicais & $\mathbf{n}$ \\
\hline Clássica & 1 \\
Eletrônica & 1 \\
Forró & 1 \\
Gospel & 6 \\
Jazz & 2 \\
MPB & 22 \\
Pop & 2 \\
Rap & 1 \\
Rock & 10 \\
Samba & 3 \\
Sertanejo & 1 \\
Tango & 1 \\
Total & 51 \\
\hline
\end{tabular}

Conforme foi observado na Tabela 5.10, o descanso, a assistência à televisão e os cuidados com a casa, envolvem as três próximas atividades desenvolvidas frequentemente por um número significativo de estudantes durante o tempo livre. No caso dos programas televisivos, observou-se a preferência pelas emissões de entretenimento, exemplificadas pelas séries (17 citações), filmes (14 citações) e programas de variedades (6 citações), enquanto as emissões culturais envolvendo debates, telejornais e documentários atingiram um total de 13 indicações. É importante destacar que a preferência pela programação televisiva de caráter instrutivo demonstrou estar associada a níveis de renda per capita mais baixos (abaixo de 2 salários mínimos) e formação familiar não universitária.

De modo geral, a observação das atividades desenvolvidas frequentemente pelos respondentes da FEUSP indicam o predomínio das práticas culturais domiciliares, cuja análise relacionada aos turnos permite afirmar que o uso da internet e o hábito de assistir televisão não variam significativamente entre os dois períodos. Por outro lado, os alunos do diurno indicaram possuir mais tempo livre para o descanso, ao mesmo tempo que se destaca entre eles a prática da escuta musical, ao passo que no período noturno é mais frequente a prática da leitura.

A forma de uso menos frequente do tempo livre é aquela que envolve a realização de práticas de lazer externas, dentre as quais constam idas ao cinema, concerto, teatro, museu, além da prática esportiva, visitação a parques e realização de viagens, tal como ilustra a Tabela 5.13: 
Tabela 5.13 - Frequência de atividades culturais e de lazer realizadas pelos respondentes da USP.

\begin{tabular}{|c|c|c|c|c|}
\hline Variáveis & Categorias & $\mathrm{n}$ & Diurno & Noturno \\
\hline \multirow[t]{3}{*}{ Cinema } & Frequentemente & 23 & 4 & 19 \\
\hline & Ocasionalmente & 26 & 9 & 17 \\
\hline & Raramente & 7 & 2 & 5 \\
\hline Total & & 56 & 15 & 41 \\
\hline \multirow[t]{4}{*}{ Concertos } & Frequentemente & 1 & 1 & 0 \\
\hline & Ocasionalmente & 12 & 4 & 8 \\
\hline & Raramente & 25 & 8 & 17 \\
\hline & Nunca & 16 & 2 & 14 \\
\hline Total & & 54 & 15 & 39 \\
\hline \multirow[t]{4}{*}{ Esporte } & Frequentemente & 18 & 6 & 12 \\
\hline & Ocasionalmente & 15 & 4 & 11 \\
\hline & Raramente & 13 & 5 & 8 \\
\hline & Nunca & 9 & 0 & 9 \\
\hline Total & & 55 & 15 & 40 \\
\hline \multirow[t]{3}{*}{ Museus } & Frequentemente & 7 & 2 & 5 \\
\hline & Ocasionalmente & 27 & 8 & 19 \\
\hline & Raramente & 21 & 5 & 16 \\
\hline Total & & 55 & 15 & 40 \\
\hline \multirow[t]{4}{*}{ Parques } & Frequentemente & 17 & 4 & 13 \\
\hline & Ocasionalmente & 22 & 6 & 16 \\
\hline & Raramente & 15 & 5 & 10 \\
\hline & Nunca & 1 & 0 & 1 \\
\hline Total & & 55 & 15 & 40 \\
\hline \multirow[t]{4}{*}{ Shows musicais } & Frequentemente & 5 & 2 & 3 \\
\hline & Ocasionalmente & 23 & 5 & 18 \\
\hline & Raramente & 17 & 7 & 10 \\
\hline & Nunca & 10 & 1 & 9 \\
\hline Total & & 55 & 15 & 40 \\
\hline \multirow[t]{4}{*}{ Teatro } & Frequentemente & 2 & 1 & 1 \\
\hline & Ocasionalmente & 25 & 6 & 19 \\
\hline & Raramente & 23 & 7 & 16 \\
\hline & Nunca & 4 & 1 & 3 \\
\hline Total & & 54 & 15 & 39 \\
\hline \multirow[t]{4}{*}{ Viagem } & Frequentemente & 9 & 3 & 6 \\
\hline & Ocasionalmente & 25 & 9 & 16 \\
\hline & Raramente & 20 & 3 & 17 \\
\hline & Nunca & 1 & 0 & 1 \\
\hline Total & & 55 & 15 & 40 \\
\hline
\end{tabular}

Em meio às saídas culturais a visita ao cinema foi indicada como a prática mais frequente, abrangendo, porém, menos da metade do grupo investigado (23/56). Dos cinquenta e seis respondentes, onze afirmaram não lembrar o nome do último filme visto no cinema, estando entre eles dois alunos que disseram ir às salas de exibição frequentemente, além de oito estudantes que afirmaram assistir filmes ocasionalmente. No total, foram informados quarenta e quatro títulos ${ }^{9}$ de filmes que indicaram a predileção dos alunos pelo cinema americano (31/44). Dentre os títulos mencionados (Quadro 5.3) destacaram-se pela recorrência as produções que contaram com elevado nível de popularidade, as quais alcançaram grande

\footnotetext{
${ }^{9}$ Não foi possível identificar um dos títulos, consequência do modo impreciso como a informação foi prestada pelo respondente.
} 
sucesso de bilheteria, tais como: "Meu Malvado Favorito 2"; "O Cavaleiro Solitário"; "O Homem de Aço"; "Wolverine imortal"; "Os Smurfs 2" e "Círculo de Fogo", entre outros. Escapando da produção cinematográfica norte-americana, o cinema europeu, por sua vez, teve cinco títulos mencionados por oito respondentes, enquanto o cinema nacional contou com a presença de apenas três títulos. Deve ser destacado o fato do cinema europeu concentrar entre seus respondentes aqueles que possuem uma condição socioeconômica e cultural distintiva. Trata-se, portanto, de alunos que estudaram em escolas particulares e que pertencem a famílias com alto poder aquisitivo e cultural. Por outro lado, verificou-se que os alunos que afirmaram não lembrar do nome do último filme visto no cinema não possuem um perfil social menos privilegiado.

\section{Quadro 5.3 - Listagem do último filme visto no cinema pelos respondentes da FEUSP.}

\begin{tabular}{|c|l|}
\hline \multirow{2}{*}{ Cinema americano } & $\begin{array}{l}\text { A morte do demônio (2013); A última grande lição (1999); Antes da meia-noite (2013); As aventuras de } \\
\text { Pi (2) (2012); Círculo de Fogo (2) 2013; Gente Grande 2 (2013); Guerra Mundial Z (2013); Marina } \\
\text { Abramovic - Artista Presente (2013); Meu Malvado Favorito 2 (6) (2013); O Cavaleiro Solitário (3) } \\
\text { (2013); O Homem de Aço (3) (2013); Os Estagiários (2013); Os Smurfs 2 (2) (2013); Peixe Grande e } \\
\text { Suas Histórias Maravilhosas (2003); Percy Jackson e o Mar de Monstros (2013); Red } 2 \text { (2013); Truque } \\
\text { de mestre (2) (2013) e Wolverine imortal (3) (2013) }\end{array}$ \\
\hline Cinema europeu & $\begin{array}{l}\text { A caça (3) (2013); A espuma dos dias (2013); Dans la maison (2013); Hanna Arendt (2) (2013) e Vocês } \\
\text { Ainda Não Viram Nada (2013) }\end{array}$ \\
\hline Cinema nacional & Colegas (2013); Flores Raras (2013); Minha mãe é uma peça (2013) \\
\hline
\end{tabular}

As práticas culturais consagradas como legítimas e fortemente associadas tais como a frequência a museus, assistência a concertos e peças de teatro (BOURDIEU, 2013) são muito pouco frequentes entre os respondentes da FEUSP. Entre essas três, a menos comum envolveu a ida a concertos, sendo esta atividade declarada fundamentalmente como "rara" ou jamais praticada por uma parcela expressiva de alunos (41/54). A visitação a museus, por sua vez, tendeu a ser uma prática de frequência ocasional a rara (48/55), havendo nove casos de estudantes que não conseguiram mencionar o nome do museu que mais gostou de visitar. Entre estes últimos, não foi possível observar associação significativa dos mesmos com um determinado perfil socioeconômico e cultural. Dentre os demais estudantes, obteve-se a indicação de cinquenta e um locais de visitação, havendo casos de alunos que registraram mais de um museu entre os de sua preferência. A partir dos registros, aqueles que tiveram mais de uma referência foram: Pinacoteca do Estado de São Paulo (11 indicações); Museu da Língua Portuguesa (6 indicações); Centro Cultural Banco do Brasil (5 indicações); Museu de Arte de 
São Paulo (5 indicações); Museu Afro Brasil (4 indicações); Memorial da Resistência de São Paulo (2 indicações) e Museu Catavento ( 2 indicações). Seis museus internacionais também foram citados, dentre os quais constam: British Museum (Inglaterra); Casa da Arte de Zurique (Suíça); Museu Nacional Centro de Arte Reina Sofia (Espanha); Museu Nacional de História Natural (EUA); Museu do Louvre (França) e Museu d'Orsay (França). É importante destacar que a indicação de museus estrangeiros demonstrou clara associação entre os respondentes e a formação em escolas particulares, além dos mesmos pertencerem a famílias com elevado capital econômico e cultural.

Em relação às apresentações teatrais (Quadro 5.4), vinte e dois alunos não souberam informar o nome da última peça assistida. Outros quatro estudantes indicaram respostas vagas, tais como "Uma de um amigo" ou "Quando tinha 12 anos, na igreja", além de mais cinco alunos cujos nomes registrados não permitiram a identificação da apresentação à qual estavam se referindo. Ou seja, trinta e um alunos demonstraram pouca familiaridade com essa manifestação cultural, entre cinquenta e seis respondentes. Dos vinte e cinco títulos registrados foi possível observar a preferência dos alunos por dramas, peças infantis e musicais. Verificouse também a existência de uma tendência dos respondentes pela escolha de apresentações que contam com a participação de atores com grande inserção nas programações televisivas (“Camille e Rodin"; "Ensina-me a viver"; "Mágico de Oz"; "Música para cortar os pulsos"; "Um violinista no telhado" e "Viver sem tempos mortos"), além de produções que contaram com forte divulgação publicitária (“A Família Addams - musical” e "Rei Leão - musical”). Peças escritas por autores conhecidos como Jean-Paul Sartre ("Entre quatro paredes") e William Shakespeare (“A megera domada"), clássicos da literatura (“O Pequeno Príncipe”; “A Bela e a Fera") ou reconhecidas pela crítica especializada ("Crônica da casa assassinada"), também se fizeram presentes.

Apesar de pesquisas na área das práticas culturais demonstrarem que o nível de escolaridade e a classe social atuam como variáveis decisivas para a frequência ao teatro, sendo esta prática realmente pouco comum em meio ao grupo, foi possível observar entre os respondentes que os níveis de renda mais elevados estão fortemente relacionados à assistência de peças que contaram com divulgação midiática, tal como musicais e espetáculos encenados por atores conhecidos. As demais apresentações citadas, porém, não guardam nenhum tipo de relação com níveis socioeconômicos e culturais. 
Quadro 5.4 - Lista da última peça de teatro assistida - FEUSP.

\begin{tabular}{|c|c|c|}
\hline & Títulos mencionados & Não souberam informar \\
\hline Teatro & $\begin{array}{l}\text { A Bela e a Fera; A megera domada; A nova roupa do rei; As aventuras de Bambolina; } \\
\text { Bandeiras de retalho; Café Frágil; Camille e Rodin; Crônica da casa assassinada; Donka: } \\
\text { uma carta a Tchekhov; Ensina-me a viver; Entre quatro paredes; Mágico de Oz; Meia noite } \\
\text { em São Paulo; Mônica e Cebolinha no mundo de Romeu e Julieta; Mulheres; Música para } \\
\text { cortar os pulsos; A Família Addams - musical; O girador do pequeno teatro de torneado; O } \\
\text { longo caminho que vai de zero a ene; O mistério Bufo; O pequeno príncipe; Rei Leão, o } \\
\text { musical (2); Um violinista no telhado; Viver sem tempos mortos. }\end{array}$ & 22 alunos \\
\hline
\end{tabular}

As últimas três práticas fracamente desenvolvidas pelos respondentes durante seu tempo livre envolveram a prática esportiva, passeios em parques e viagens. A vivência do esporte tendeu a ser mais presente entre os alunos que estudam no período diurno, numa clara relação entre a prática, a maior posse do tempo livre e níveis mais elevados de renda. Entre as modalidades mencionadas constam aquelas praticadas em academias como: dança, yoga, natação, hidroginástica, lutas, pilates e musculação, realizadas por quinze estudantes. Esportes que prescindem de vínculos com locais específicos para a sua prática foram os segundos a serem enumerados, dentre os quais constam: andar de bicicleta, correr e caminhar (citado por nove alunos). Por fim, foram listados os esportes coletivos como vôlei, futebol e handball, praticados por sete estudantes. Botelho e Fiore (2005) identificaram que a prática esportiva, de modo geral, é mais comum entre a população jovem, portadora de maior capital econômico e cultural. O futebol, no entanto, não se constitui como uma atividade física própria das classes privilegiadas, sendo esta prática também difundida em meio aos grupos populares. Por outro lado, o vôlei e o handball se fazem mais presentes nas classes sociais elevadas, assim como a frequência a academias (GOLDSTEIN; SILVA, 2014). O hábito de viajar também se configura como prática vinculada às camadas sociais com maior poder aquisitivo e disposição de tempo livre, sendo esta atividade rara em meio à maior parte dos estudantes do período noturno e ocasional para parcela significativa dos alunos do vespertino. Por último, apesar da frequência a parques se constituir entre os paulistanos como o local de maior visitação em relação a museus, centros culturais, cinemas e teatros (RIBEIRO, 2014), em meio aos respondentes esta prática caracterizou-se por sua eventualidade em ambos os turnos.

O estudo das atividades menos praticadas pelos respondentes da FEUSP permitiu identificar que todas, sem exceção, são externas ao ambiente doméstico e, consequentemente, demandam maior disponibilidade de tempo e dinheiro. Nesse sentido, o reduzido número de alunos que as realizam pode, em parte, ser justificado pelo fato dos mesmos usufruírem de 
pouco tempo livre, além de experimentarem algum nível de restrição financeira. Tal como foi descrito na primeira parte deste capítulo, um número significativo de alunos conciliava, no momento da pesquisa, trabalho com o último ano do curso de graduação, condição que certamente reduziu as horas que poderiam ser destinadas às práticas culturais. Porém, o cruzamento da renda familiar per capita com a frequência a concertos, museus e teatros permitiu identificar que as faixas de renda mais elevadas não estão associada a praticantes culturais assíduos. Assim como foi apontado anteriormente, entre os respondentes da FEUSP, as práticas externas mais distintivas são muito pouco desenvolvidas, independentemente da faixa de renda familiar. Considerando a frequência ao cinema, porém, foi possível verificar que a regularidade dessa prática se dá justamente entre os alunos pertencentes às famílias com rendas inferiores a dois salários mínimos. Em contrapartida, o hábito de viajar está claramente relacionado à posse de renda superior a quatro salários mínimos, do mesmo modo que a visitação assídua a parques também está associada a rendimentos familiares mais elevados.

O levantamento dos bairros ocupados pelos respondentes usuários regulares de parques (Tabela 5.14) indicou que todos são contemplados por estes espaços nas suas imediações, com destaque para os moradores da zona oeste paulista. Nesta região, os bairros indicados foram Alto de Pinheiros, Jaguaré, Perdizes, Rio Pequeno e Vila Leopoldina, cujos moradores usufruem do fácil acesso aos parques Villa-Lobos e Água Branca. Na zona sul de São Paulo os bairros habitados foram Vila Mariana, Saúde e Morumbi, contemplados pelos parques da Aclimação, Ibirapuera, do Estado, Alfredo Volpi e Parque do Povo. Na região central, os moradores da Barra Funda e Liberdade estão próximos aos parques da Água Branca e Aclimação, enquanto o aluno residente em Mandaqui (zona norte) conta com a vizinhança do Horto Florestal.

Tabela 5.14 - Bairros ocupados pelos respondentes da FEUSP no município de São Paulo.

\begin{tabular}{lll}
\hline Regiões de SP & Bairros & $\mathbf{n}$ \\
\hline Centro & Barra Funda, Bela Vista, Liberdade e Santa Cecília & 4 \\
Zona Leste & Itaquera, Sapopemba e Vila Matilde & 3 \\
Zona Norte & $\begin{array}{l}\text { Freguesia do Ó, Mandaqui (2) e Pirituba } \\
\text { Zona Oeste }\end{array}$ & $\begin{array}{l}\text { Alto de Pinheiros (3); Butantã (8); Jaguaré (1); Jaraguá } \\
\text { (2); Lapa (2); Perdizes (2); Pinheiros (2); Rio Pequeno }\end{array}$ \\
& $\begin{array}{l}\text { (5); Vila Leopoldina e Vila Sônia. } \\
\text { Zona Sul }\end{array}$ & 27 \\
& $\begin{array}{l}\text { Campo Belo; Campo Limpo; Capão Redondo; Cidade } \\
\text { Dutra; Morumbi (2); Parelheiros; Santo Amaro; Saúde } \\
\text { (2) e Vila Mariana (7) }\end{array}$ & \\
\hline
\end{tabular}


Os dados recolhidos demonstram, portanto, haver relação entre os níveis de renda e as ações culturais que envolvem a prática esportiva, viagens e a circulação em parques. No caso deste último, verificou-se também a influência da proximidade desta área de lazer em relação aos seus usuários. O cinema, por sua vez, se configurou como a atividade externa mais comum entre os respondentes (apesar de pouco frequente), abrangendo principalmente aqueles cujas famílias possuem até dois salários mínimos como faixa de renda per capita mensal. A compreensão da vulgarização desta prática exige que seja levada em consideração a maior acessibilidade das salas de exibição entre os moradores das regiões centrais e também periféricas da cidade de São Paulo, uma vez que a multiplicação das salas de cinema ocorreu na mesma proporção em que os shoppings passaram a ser instalados nas regiões mais diversificadas da cidade.

Convém lembrar, porém, tal como Botelho (2004) assinalou, que a proximidade dos equipamentos culturais não implica necessariamente na utilização dos mesmos por parte do público. Retomando os dados de pesquisa, verificou-se que a maior parte dos respondentes da FEUSP vive na região central e oeste de São Paulo (31/54). Coincidentemente, de acordo com estudo realizado por Nakagawa (2011) a respeito da distribuição dos equipamentos culturais na cidade, há uma clara concentração dos mesmos na porção centro-oeste, fato que não implicou em uma maior participação dos alunos na assistência a peças de teatro, frequência a museus e concertos. Assim, a investigação das práticas culturais deve considerar não somente o local de residência dos investigados e sua condição econômica, mas também a formação cultural do agente, bem como a bagagem cultural de sua família de origem.

De acordo com Bourdieu (2007), as práticas culturais possuem relação próxima com o capital cultural herdado no meio familiar e a transmissão cultural efetuada pela escola. A aquisição familiar da cultura envolve uma aprendizagem espontânea, dada no ambiente doméstico desde a primeira infância e que tende a ser mais ou menos enriquecedora de acordo com o volume do capital cultural, econômico e social dos responsáveis pela socialização primária do agente: "Em todos os domínios da cultura, teatro, música, pintura, jazz, cinema, os conhecimentos dos estudantes são tão mais ricos e extensos quanto mais elevada é sua origem social.” (BOURDIEU, 2013, p. 50). Partindo do processo formativo familiar, a escola delimita os elementos que compõem a cultura legítima, reforçando entre os alunos a competência de reconhecimento da mesma, cuja identificação ultrapassará os limites do espaço escolar. Assim, ao apresentar para os alunos as obras literárias validadas pela cultura formal, os estudantes terão a propensão de utilizar este referencial como ponto de partida para a seleção de novas fontes de 
leitura sobre as quais se debruçarão. Tal capacidade de diferenciação tende a ser ampliada para a análise de produções culturais que excedem os domínios escolares, generalizando-se para o reconhecimento de produções artísticas no âmbito do cinema, teatro, música, entre outras manifestações. Dito de outro modo, a ação familiar e escolar sobre os agentes, em torno de sua relação com a cultura legítima, produz disposições universais de apreciação que lhe conferem a capacidade de classificar as experiências culturais entre as que são dignas ou não de serem apreciadas.

Reconhecendo, portanto, a existência de uma relação estreita entre as práticas culturais, o capital escolar e a origem social dos agentes, importa retomar o percurso formativo dos alunos aqui investigados. Tal como foi descrito na primeira parte deste capítulo, os alunos do curso de Pedagogia da FEUSP são identificados como alunos portadores de baixo volume de capital econômico, cultural e social, quando comparados com os cursistas das graduações mais concorridas no vestibular da FUVEST (SETTON, 1999; LEME, 2012 e ISHII, KRASILCHIK, LEITE, 2014). Porém, ao comparar os cursistas da Pedagogia com as licenciaturas em Matemática e Física, foi possível identificar que os mesmos possuem um volume de capital global mais elevado, ou seja, seus pais são mais escolarizados, o nível de renda familiar se mostra superior e há mais alunos que completaram sua educação básica em escolas particulares (LEME, 2012). Essa mesma tendência foi verificada entre nossos respondentes. Quanto à trajetória escolar, identificou-se no período vespertino mais alunos oriundos de escolas particulares, enquanto no noturno houve equilíbrio entre o número de alunos egressos de escolas particulares e públicas. Em relação ao nível formativo dos pais, apesar da identificação do predomínio da formação universitária, não deve ser desconsiderado o fato de praticamente metade dos alunos, ao ingressar na universidade, ter superado o nível de escolaridade paterno e mais da metade ter ultrapassado o nível formativo de suas mães. Por fim, o nível de renda familiar apresentou uma certa dispersão, havendo um número levemente superior de famílias com renda mensal per capita entre dois e quatro salários mínimos (24/74), seguido pelos rendimentos de até um salário mínimo (21/74); entre um e dois salários mínimos per capita (18/74) e mais de quatro salários mínimos (11/74).

A partir da caracterização dos respondentes envolvidos nesta pesquisa, pode-se afirmar que os mesmos possuem uma condição social pouco distintiva, cujo processo formativo não foi capaz de produzir aspirações culturais fortemente relacionadas com o consumo de bens mais legítimos (concerto, museu e teatro), dando-se, contrariamente, a predominância de atividades culturais circunscritas ao ambiente doméstico envolvendo o uso da internet, a leitura de livros 
e a escuta musical. A prática de leitura destes alunos demonstrou a preferência pelos bestsellers, enquanto a leitura de revistas e jornais se fez praticamente inexistente. Os pouco alunos que indicaram os nomes dos periódicos lidos tenderam a registrar aqueles mais conhecidos entre o grande público, ou seja, mais facilmente resgatados pela memória. A assistência a filmes de sucesso comercial e a apresentações teatrais clássicas (Shakespeare, por exemplo), encenadas por atores globais e divulgadas fortemente pela mídia indicam a massificação do gosto, mesmo entre os poucos alunos que se dispuseram a realizá-las.

Por outro lado, os estilos musicais mencionados apresentam sinais distintivos uma vez que a preferência se deu em torno da MPB, rock, jazz, samba, tango e música clássica, sendo a escuta de tais gêneros identificada, nas pesquisas de consumo cultural brasileiras, a agentes sociais portadores de maiores níveis de formação escolar e renda. No que diz respeito aos programas televisivos, verificou-se novamente uma tendência de demonstração da posse de uma "boa vontade cultural" em que o consumo de emissões culturais (debates, telejornais, documentários) oscilou entre a preferência pelos programas massificados (séries estrangeiras, filmes e programas de variedades). A marca da distintividade também emergiu por parte de poucos alunos ao indicarem museus estrangeiros entre os seus preferidos, além do interesse pela produção cinematográfica mais restrita, exemplificada pela indicação de filmes europeus. Nestes dois casos, o nível de renda e formação cultural familiar foram decisivos para a ocorrência dessas práticas, porém o mesmo não se dá em relação ao consumo musical e à programação cultural televisiva, os quais demonstraram não possuir relação com uma origem social mais privilegiada.

A prática da leitura, por sua vez, envolveu para uma pequena parcela dos respondentes, a escolha de escritores legitimados pela cultura escolar, além de obras clássicas da literatura e autores consagrados, bem como livros de teor político, histórico e sociológico, revelando interesses por obras de conteúdo intelectualizado e reflexivo. Do mesmo modo, enquanto a parte mais representativa dos respondentes indicava sua preferência pela leitura de revistas e jornais de grande circulação, alguns poucos estudantes assinalaram sua disposição para a leitura de revistas diferenciadas e jornais internacionais. No caso da escolha dos livros, não foi possível observar a existência de um público diferenciado, porém, os leitores de revistas e jornais distintivos são claramente portadores das maiores faixas de renda e formação cultural familiar.

Assim, considerando o conjunto das respostas, é possível caracterizar parte significativa dos respondentes da FEUSP como portadores de fraco interesse cultural, cujo consumo é orientado para as produções comerciais, populares, portadoras de conteúdo que 
permitem o proveito fácil do seu público. Por outro lado, foi possível observar a existência de uma pequena parcela de alunos que apresentaram práticas culturais relativamente seletas, portadoras de certo caráter intelectual ou artístico. Nestes casos, porém, não foi observada a existência de regularidade na seleção dos objetos culturais distintivos, de modo que leitores de revistas e jornais estrangeiros ou de conteúdo intelectualizado, leem best-sellers e assistem aos blockbusters norte-americanos. Do mesmo modo, a assistência a filmes europeus ou a leitura de livros diferenciados não tem relação com a realização concomitante de outras ações culturais distintivas, tal como frequentar museus, concertos ou teatros.

A inconstância das práticas observada pode ser interpretada como o resultado de uma modesta familiaridade dos agentes com os bens culturais legítimos. Deve-se considerar, portanto, que a origem social e o capital escolar dos respondentes não favoreceram o estabelecimento de um habitus culto, estruturado precocemente por meio da convivência familiar e aprofundado pela educação escolar. Contrariamente, a capacidade demonstrada por parte destes alunos de indicar algumas práticas distintivas, em meio a outras distanciadas dessa característica, oferece indícios de um aprendizado tardio e acelerado, o qual foi incapaz de enraizar no agente a durabilidade e constância de seus efeitos (BOURDIEU, 2007).

A pobreza das práticas culturais evidenciada pelos respondentes, associada a uma quase inexistente demonstração da posse de "boa vontade cultural", revela o fraco sentido do jogo interiorizado por esses agentes, ou seja, a incapacidade de responder de modo adequado às variadas demandas existentes nas disputas sociais. Trata-se, portanto, de agentes cujo volume global dos capitais pouco ofereceu em termos do conhecimento acerca dos modos como as disputas sociais se dão no interior dos campos. Enquanto entre as classes dominantes o habitus se ajusta imediatamente às regras do jogo, em meio aos grupos sociais menos privilegiados nota-se a posse de um senso prático que encontra resistências para compreender e se adequar às exigências do jogo social. Nas palavras de Bourdieu (2004, p. 82):

O habitus como social inscrito no corpo, no indivíduo biológico, permite produzir a infinidade de atos de jogo que estão inscritos no jogo em estado de possibilidade e de exigências objetivas; as coações e as exigências do jogo, ainda que não estejam reunidas num código de regras, impõem-se àqueles e somente àqueles que, por terem o sentido do jogo, isto é, o senso da necessidade imanente do jogo, estão preparados para percebê-las e realizá-las. 


\subsection{ESCOLHA PROFISSIONAL, PERSPECTIVAS OCUPACIONAIS E FORMATIVAS: A REVELAÇÃO DE AGENTES COMPROMETIDOS}

Entre os respondentes da FEUSP envolvidos nesta investigação, verificou-se que dois em cada cinco alunos tinham o curso de Pedagogia como sua primeira opção formativa (27/65), enquanto mais da metade dos alunos informaram desejar inicialmente seguir outras carreiras (38/65). A interpretação do elevado número de alunos que afirmaram ter no curso de Pedagogia sua segunda opção formativa deve ser associada ao fato de existir nesse grupo de respondentes uma parcela significativa de cursistas já graduados ou que iniciaram outros cursos sem que os mesmos fossem concluídos.

O estudo das razões que levaram os alunos que não tinham o curso de Pedagogia como primeira opção formativa a frequentar essa graduação permitiu identificar duas grandes categorias de argumentos, notadamente ligados a interesses profissionais (20/38) e restrições objetivas (9/38). Iniciando o detalhamento a partir das respostas que manifestaram interesses profissionais, foram observadas:

$\checkmark$ expectativas de mudança da área de atuação profissional (8/20) ("Não me vejo atuando na área que atuo hoje (informática) até ficar velhinha. Por outro lado, sinto que poderia trabalhar com educação, principalmente com crianças até lá.");

a perspectiva de ampliar o campo de atividade profissional (5/20) (“A Pedagogia seria um modo de ampliar meu campo de trabalho, já que só minha formação em História, restringe o mesmo."; "Por ver que na área da minha primeira formação (Ciências Sociais) há uma dificuldade de inserção no mercado de trabalho.”);

$\checkmark$ o interesse em complementar os conhecimentos obtidos na primeira graduação tendo em vista seu aperfeiçoamento (4/20) ("Quando comecei a lecionar como professora de História resolvi que precisava estudar Pedagogia.")

$\checkmark$ e a expectativa de lecionar nas séries iniciais (3/20), demonstrando a preferência, ou a posse de uma atitude precavida, que as levou a ter em vista atuar na docência, porém, junto aos alunos mais jovens: "Gostaria de lecionar em séries iniciais." 10 ; "Minha cunhada que se formou em Geografia na FFLCH me aconselhou a ficar na educação [Faculdade de Educação] devido ao ambiente e alunos." 11

O segundo grupo de argumentos que levou os alunos ao curso de Pedagogia, sendo esta sua segunda opção formativa, abrangeu as restrições objetivas de ordem econômica (2/9), cultural (6/9) (reprovação no vestibular) e por localidade (dificuldade de acesso) (1/9) (“Localização da faculdade") ${ }^{12}$. As limitações financeiras influenciaram a decisão seja para dar

\footnotetext{
${ }^{10}$ Neste caso o curso inicialmente pretendido era licenciatura em Ciências da Natureza.

${ }^{11}$ Para essa respondente sua primeira opção era Ciências Sociais.

${ }^{12}$ Neste caso o curso desejado pelo respondente era História da Arte oferecido pela UNIFESP de Guarulhos.
} 
início ao curso ("Ao terminar o ensino médio, minha vontade era cursar rádio e tv na faculdade Cásper Líbero, entretanto, o valor das mensalidades estava muito acima do orçamento da minha família.”), como também envolveu preocupações acerca do retorno econômico que o curso realmente desejado traria após a sua conclusão ("Gostaria de cursar Filosofia. Acabei optando por Pedagogia, na época, por achar que seria um curso que abrisse mais portas de trabalho (...).”). Para além dos limites financeiros, a reprovação no vestibular foi apontada por seis estudantes, estando entre os cursos desejados as graduações em Artes Cênicas, Artes Visuais, Biologia, Design e Direito. Em algumas respostas, o fato de não ter passado no vestibular é acompanhado da explicação do curso de Pedagogia ter algum ponto em comum com o curso inicialmente pretendido: "Na verdade gostaria de ser professora de Artes, como não passei na prova específica acabei optando pela Pedagogia por ser um sonho dar aula.”; “Após diversos fracassos nas provas práticas para o curso de licenciatura em Artes Cênicas, tentei a reescolha em Pedagogia, pois possuía o desejo de ser professora da área de artes e Pedagogia era o segundo curso mais próximo do meu desejo." Houve casos, ainda, que os fatores financeiros e a concorrência no vestibular agiram de modo integrado como limitadores da escolha profissional: "Não passei na FUVEST e ao pensar em fazer uma particular ponderei melhor minha escolha e percebi que no futuro profissional talvez eu não me saísse tão bem quanto eu gostaria.”, porém, novamente a resposta do estudante indica a elaboração de um discurso resignado frente às circunstâncias que cercearam sua liberdade de escolha.

A ausência de justificativas ou a utilização de respostas esquivas e abreviadas também tiveram ocorrência (4/38), impedindo a identificação real dos motivos produtores da mudança de rumo formativo, tal como o aluno que desejava cursar Jornalismo e justificou sua nova escolha pela "Falta do inglês" ou o estudante que almejava o curso de Psicologia e que fundamentou seu ingresso na Pedagogia por "Amadurecimento". ${ }^{13}$

O número elevado de respondentes que assinalaram o curso de Pedagogia como sua segunda opção (38/65) deve ser observado considerando-se os dezenove alunos já formados, além de outros dezesseis estudantes que já haviam dado início a um curso de graduação, sem que o mesmo fosse concluído. Desse conjunto de respondentes, vinte e sete indicaram a Pedagogia como sua segunda opção. Esses respondentes dividem-se entre os licenciados e bacharéis. Os já licenciados buscaram na Pedagogia a formação continuada e o acesso a conhecimentos específicos, como aprender a alfabetizar. Entre eles, é possível notar uma certa expectativa de que o curso os auxilie no enfrentamento dos desafios que envolvem a profissão

\footnotetext{
${ }^{13}$ Cinco alunos não responderam o motivo da mudança de sua opção profissional.
} 
docente e seu cotidiano profissional. Outros indicaram a perspectiva de, com o diploma de Pedagogia, sair da sala de aula e ocupar cargos na administração escolar, ascendendo profissionalmente por meio da ampliação salarial e do valor simbólico envolvido no trabalho a ser desempenhado. Entre os bacharéis, a inserção na Pedagogia envolveu a busca por novos campos de atuação profissional, seja pela expectativa de desempenhar uma atividade mais próxima de seus atuais interesses profissionais, seja por dificuldades na obtenção de emprego na área de formação anterior.

A inserção no curso de Pedagogia da FEUSP como segunda opção de formação profissional, por motivos limitadores das possibilidades de escolha, foi comunicada por somente nove respondentes. Em relação às limitações financeiras, o curso foi eleito pela possibilidade de ingresso em uma universidade pública ("minha mãe não teria dinheiro para pagar um curso particular.”) e pelo fato do mesmo oferecer maiores chances de inserção profissional. Enge (2004), ao investigar o processo de profissionalização inicial de egressos de cursos de licenciatura da USP, observou as mesmas circunstâncias de escolha profissional aqui apontada. Por vezes, a decisão por um determinado curso envolve menos o interesse de profissionalização em uma determinada área, do que a preocupação em concluir um curso que oferecesse boas chances de colocação profissional. Ainda, a autora também identificou depoimentos de egressos que viram na gratuidade do curso a principal razão da sua "escolha", mesmo que isso tenha significado o abandono do curso que representava a opção principal.

As dificuldades com o vestibular, por sua vez, levaram os alunos a identificar aproximações entre o desejado e o possível: "Na verdade gostaria de ser professora de Artes, como não passei na prova específica acabei optando pela Pedagogia por ser um sonho dar aula."; “Pedagogia era o segundo curso mais próximo do meu desejo.” De acordo com Bourdieu (2013), a vivência de uma escolha profissional forçada por determinados cursos demonstra a desvantagem escolar experimentada pelos agentes situados nas camadas inferiores e médias, até quando os mesmos compreendem sua escolha como fruto de sua vocação. A adequação das escolhas profissionais manifestada pela procura de cursos que de algum modo se aproximam do inicialmente desejado representa a vocação efetiva, ou seja, a realização do ajustamento entre a expectativa e a realidade. Assim, entre os grupos sociais menos privilegiados a opção por um determinado curso não resulta de livre escolha, mas da seleção por determinados cursos com os quais é possível sonhar, tal como exemplifica o primeiro depoimento desse parágrafo. 
Esse processo de ajuste executado pelo agente poderia ser facilmente interpretado como o resultado de uma ação conscientemente deliberada. Entretanto, Bourdieu elucida que os modos de ação e pensamento dos agentes, inclusive nos procedimentos de escolha profissional, são mediados pelo habitus. As práticas que têm no habitus a sua origem são guiadas pela incorporação subjetiva da estrutura social, de acordo com a posição ocupada pelo agente, sendo esta definida pelo volume da posse de diferentes capitais (econômico, cultural e social). Consequentemente, as diferenças expressas nas práticas, na posse de bens, e nos modos de pensar tornam-se diferenças simbólicas, sendo o habitus de cada indivíduo o informante do seu grupo de pertencimento social (Bourdieu, 2007).

No processo de escolha profissional, portanto, os agentes das classes populares e médias possuem suas aspirações guiadas pelas condições objetivas que se relacionam com sua categoria social de pertencimento. Tendo incorporado a estrutura social e longe de qualquer cálculo racional, as práticas dos agentes são coerentes com sua condição de origem e comuns entre os membros que partilham de uma mesma posição social. Nesse sentido, os agentes selecionam objetivos tangíveis e adequados às suas condições de realização, tal como ilustra o estudante que desejava ter cursado Direito, mas terminou por ingressar no curso de Pedagogia: "Não passei na FUVEST e ao pensar em fazer uma particular ponderei melhor minha escolha e percebi que no futuro profissional talvez eu não me saísse tão bem quanto eu gostaria.” Esse exemplo bem ilustra a afirmação de Bourdieu (2013) de que o habitus harmoniza expectativas e probabilidades. Trata-se de um conhecimento prático que leva cada agente a viver em conformidade com a sua condição de origem.

Mas o que levou os formandos envolvidos nesta pesquisa, independentemente de sua inserção na Pedagogia resultar de primeira ou segunda opção, a escolherem esse curso? A partir das respostas oferecidas, foi possível identificar quatro argumentos fundamentais, ligados aos seguintes fatores: a) o interesse pela docência e ascensão na carreira do magistério (24/53); b) a importância social da profissão (12/53); c) o conteúdo formativo do curso (11/53) e d) a influência externa, social e familiar (05/53).

Os respondentes que manifestaram possuir algum nível de interesse pela profissão e pelas possibilidades de ascensão no quadro do magistério demonstraram expectativas diversas, desde a intenção de trabalhar com crianças, além do desejo pelo exercício do magistério ("Desde adolescente sinto-me atraída pela educação, pela docência, por ensinar as crianças.”). A extensão das oportunidades de trabalho trazidas pelo curso também foram mencionadas: "A diversidade de campos que um pedagogo pode atuar.", assim como foi 
apresentado como elemento de atração a possibilidade do trabalho docente ser desempenhado em meio período "A flexibilidade em atuar na profissão e formar uma família."

Especialmente entre os já graduados em cursos de licenciatura o argumento para a escolha da Pedagogia envolveu as justificativas da formação continuada ("Melhorar meu desempenho profissional”; “Continuar meus estudos.”), bem como o interesse de aprenderem a alfabetizar, uma vez que seus alunos estão ingressando no Ensino Fundamental sem o domínio da leitura e da escrita ("Quis aprender mais sobre o processo de alfabetização pra auxiliar meus alunos que chegam no $6^{\circ}$ ano sem serem alfabetizados.”). A perspectiva de ampliação das opções de atuação profissional, por sua vez, se fez presente tanto entre os já licenciados, como entre profissionais de outras áreas do conhecimento. No caso dos primeiros, prevaleceu a perspectiva de assumir novas posições de trabalho na administração escolar ("Desejo de atuação na gestão escolar.”), enquanto entre os segundos a intenção era contar com novas possibilidades de ação ( “Ter uma segunda opção de atuação no mercado de trabalho”).

A segunda categoria de respostas diz respeito à escolha do curso de Pedagogia por motivações que envolvem o comprometimento com as causas sociais. Entre estes alunos existe a crença compartilhada de que é possível por meio da ação educacional formar pessoas mais "conscientes", "críticas" e dotadas de valores, iniciando assim um processo mais amplo de mudança social:

"Pode soar uma utopia, mas acredito que sendo professora de crianças pequenas, eu posso ajudar a melhorar o mundo, auxiliando no crescimento de pessoas boas e justas.”;

“(...) a dita revolução deve iniciar na educação.”;

“Possibilidade de contribuir para um mundo melhor.";

"Acreditar na importância da educação para a construção de uma sociedade composta por indivíduos conscientes e críticos.”

Importa comentar que, entre os onze alunos que apresentaram o discurso do engajamento, sete já haviam iniciado ou concluído cursos de graduação anteriormente, não havendo entre eles, porém, nenhum licenciado.

Os conteúdos do curso também serviram como estímulo para a decisão de cursar Pedagogia. Neste grupo os respondentes possuíam interesses múltiplos que variavam do entusiasmo por temas próprios da educação tais como educação especial, dificuldade de aprendizagem ou didática, bem como o desejo por uma formação no âmbito das humanidades: 
“(...) eu tinha interesse por crianças com dificuldades de todos os tipos, eu pensava em fazer psicopedagogia.";

"A busca por uma formação clássica e humanística”;

“Gostaria de saber mais da área da educação”;

"Meu interesse inicial foi pela educação especial. Tenho dois tios com deficiência intelectual e sempre me interessei pela temática." $e$

"A curiosidade de saber como se dão os processos educativos e a vontade de aprender a ensinar alguém."

A influência externa sofrida pelos alunos no momento de decidir pelo curso de pedagogia teve participação familiar (4/5) e de antigos professores (1/5). Nos quatro casos em que se deu a influência familiar, os alunos eram filhos de docentes. Em suas respostas, os alunos destacaram o fato das questões educacionais terem feito parte de sua vida, sendo consolidada entre os mesmos uma certa familiaridade e interesse pela profissão:

"Minha principal influência foi minha mãe, pois como a mesma já é Pedagoga, fui convivendo com isto desde minha infância, por isso acabei me apaixonando pela profissão.";

"Meus pais são professores e sempre estive permeada por vivências educacionais. Acabei optando por seguir a tradição e entender melhor os problemas que ouvi a vida inteira sobre educação.”.

A respeito da influência de antigos professores, houve apenas uma única menção, registrada de modo bastante breve: "Experiência com antigos professores."

A partir dos relatos dos respondentes, foi identificado que a escolha do curso de pedagogia contou com quatro motivações fundamentais: a) interesse pela docência e pelas possibilidades de ascensão no quadro do magistério; b) importância social da profissão; c) conteúdo formativo do curso e d) influência externa social e familiar. A primeira categoria foi a que abrangeu o maior número de justificativas e o mesmo se manifestou de forma distinta de acordo com o perfil dos respondentes. Os que já eram professores buscavam a formação continuada ou a oportunidade de assumir cargos na administração escolar, enquanto os bacharéis desejavam ampliar suas chances de inserção no mercado de trabalho. Para os não formados, a amplitude do campo de atuação profissional do pedagogo foi mencionado como um atrativo da profisssão, além da expectativa pelo exercício do magistério e pela intenção de trabalhar com crianças. 
O interesse pelo exercício do magistério, bem como a expectativa de trabalhar com crianças também foi observado nas pesquisas realizadas em diversos países europeus (França, Austrália, Canadá, Eslováquia, Holanda, Reino Unido) a respeito da motivação de seus professores para o desempenho da atividade docente, sendo estas as duas principais justificativas apresentadas pelos mesmos. Notou-se, ainda, que a perspectiva de contribuir para a sociedade também se configurou como fator relevante na condução das pessoas ao exercício da docência (OCDE, 2006), sendo essa a segunda motivação mais recorrente entre os respondentes da FEUSP. Esse mesmo dado foi identificado por Leme (2012, p. 143) entre os convocados em primeira chamada para matrícula na Pedagogia da USP no ano de 2010, em suas palavras “o 'engajamento social' recebeu na Pedagogia uma das mais altas pontuações para influência na escolha do curso", sendo essa perspectiva, portanto, recorrente entre esse alunado.

Marin (2003, p.62), a partir do depoimento de professoras das séries iniciais, investigou a decisão de ingresso das mesmas em cursos de formação e suas perspectivas de atuação na docência. Em meio aos relatos, a autora identificou motivações pouco associadas ao objetivo central da ação docente, qual seja o de conduzir o processo formativo dos alunos. Entre as que não queriam atuar como professoras o ingresso no curso se deu por restrições materiais como a falta de condições financeiras ou a necessidade de "estudar para poder sobreviver", além de outras justificativas como ser o curso disponível na cidade ou convivência com familiares que atuam na profissão. Por outro lado, entre as professoras que queriam exercer o magistério, deu-se a ocorrência de depoimentos em que o ensino e a aprendizagem se fizeram presentes, porém, novamente ocorreu a manifestação de justificativas que se distanciavam da finalidade primeira do trabalho docente ou cujo argumento demonstrava uma fraca “compreensão do significado social da profissão docente." (p. 62). Ao utilizar um modo de apreciação das justificativas de escolha profissional entre os respondentes da FEUSP, próximo ao empregado por Marin (2003), pode-se afirmar a existência nesse grupo de uma escolha profissional, mesmo que por vezes objetivamente determinada, associada ao sentido fundamental do trabalho de um pedagogo: interesse pelas questões de ensino, pela função social e política do trabalho e pelos conteúdos que envolvem o domínio de conhecimentos específicos da profissão.

A clareza acerca do sentido social da profissão é novamente demonstrada pelos respondentes da FEUSP ao definirem o que é ser professor, uma vez que os mesmos tenderam 
a destacar os aspectos formativos que envolvem a profissão $(30 / 53)^{14}$. Assim, para esses alunos, a docência envolve a ação de ensinar e fazer com que os alunos aprendam ("Ser professor é estar comprometido com o ensino e levar o aluno para perto do conteúdo.”; “O papel do professor é ensinar, mas também deve auxiliar os alunos e as crianças para que aprendam.”). Ao destacarem o papel do professor como aquele que ensina, os alunos indicaram também como concebem a situação de ensino, valorizando as concepções de professor mediador ("Ser professor é mediar e democratizar o conhecimento"; "Mediar o aprendizado do aluno, motivando-o e auxiliando em suas dificuldades.”) ou de professor que se preocupa em conceder ao aluno a oportunidade de fazê-lo aprender de forma autônoma ("O professor ajuda a construir o conhecimento”; “Ensinar a aprender.”). Ao mesmo tempo, muitos respondentes destacaram que o processo de aprendizagem não envolve somente os alunos, mas também o próprio professor, o qual é apresentado como um profissional que deve conceber seu processo formativo como algo inacabado, além de ter disposição para buscar sempre a atualização dos seus conhecimentos:

“Ser professor é um constante aprendizado.”;

"É uma escolha que fiz porque ser professor não é só ensinar, mas acima de tudo é aprender com o outro, é saber que juntos podemos com crianças, adolescentes, jovens, adultos e portadores de necessidades especiais ensinar e aprender (...).”;

"É ter o desejo de ensinar, a busca por ensinar e por aprender."

Ainda no mesmo agrupamento de respostas que abordaram a definição do que é ser professor a partir dos objetivos formativos, deu-se a ocorrência de reflexões em torno do professor educador, ou seja, aquele que, além de lidar com os conteúdos disciplinares, também está preocupado com a formação dos valores de seus alunos:

“Contribuir para a formação intelectual e de caráter das pessoas pelas quais se torna responsável.”;

"Para mim, ser professor, significa ser educador!” (...) Aquele que se preocupa em informar e formar."

A segunda categoria elaborada a partir das representações dos respondentes a respeito do que é ser professor abrangeu as respostas que enfatizaram os impactos sociais desse trabalho (15/53). Nesse sentido, ser professor é fundamentalmente formar pessoas reflexivas,

\footnotetext{
${ }^{14}$ Dentre as cinquenta a três respostas registradas, três não definiram o que é ser professor.
} 
questionadoras, críticas e socialmente ativas, ou seja, capazes de compreender o meio social no qual estão inseridas, identificar seus problemas e agir tendo em vista a produção de mudanças:

"Professor é aquele que faz com que seus alunos não apenas aprendam conteúdos, mas faz com que eles se conscientizem e usem esses conteúdos para serem cidadãos conscientes e ativos dentro da sociedade em que vivem.";

"É possibilitar que os sujeitos em formação, juntamente com os colegas trabalhadores, possam refletir sobre o mundo e seus conflitos. Para que os sujeitos possam participar dele tendo mais clareza dos fatos sociais, da sua inserção e participação nele, para poder pensar também os próprios atos e escolhas.” $e$

"Ser uma pessoa que trabalha, investe seus esforços em orientar outras pessoas na sua educação. (...) investe nas relações humanas, em discutir as questões de seu tempo, em desvelar o que a mídia insiste em deixar escondido, retomar a história do passado para entender o hoje, ensinar meios de ser atuante e a lutar por direitos.”

Cabe observar que todas as respostas, cuja dimensão social do trabalho docente foi indicada como a principal caracterização acerca do que é ser professor, não atribuíram diretamente a este profissional a capacidade de transformar a sociedade. De modo contrário, é possível notar na construção dos argumentos que a ação docente consiste, sobretudo, em formar um aluno pensante e socialmente consciente, sendo este o fundamento da ação política do magistério apresentado por esses respondentes.

O modo como os respondentes da FEUSP definiram a atividade docente consistiu justamente na indicação do significado social desse trabalho que envolve a "mediação necessária entre o alunado e o conhecimento" (MARIN, 2003, p.60). Assim, é possível identificá-los como portadores de uma clara consciência acerca do sentido da profissão que, para eles, envolve mais do que a transmissão de conteúdos, mas também a necessária formação moral e crítica dos estudantes (BASSO, 1998).

As duas grandes categorias formuladas a partir das respostas dos formandos da FEUSP, a respeito do que é ser professor, terminaram por abranger quase a totalidade dos registros (45/53). Considerando que três alunos não definiram o que é ser professor (um aluno anulou sua resposta, enquanto outros dois registraram: “Ainda estou descobrindo.”; "Não consigo definir."), restaram cinco apontamentos que não foram incluídos na delimitação formulada, os quais serão comentados a seguir.

Somente por duas vezes, a definição do significado de ser professor ocorreu a partir da descrição da conduta docente. Nas respostas apresentadas emergiu a perspectiva de que o professor deve ter uma atitude modelar, caracterizada pela integridade e comprometido com 
seu trabalho: "Ser um exemplo na sociedade e para seus alunos." e "Ético, técnico, profissional e responsável por suas ações.” As outras três respostas, por sua vez, possuem em comum uma característica contestadora, um certo tom de crítica e de descontentamento em relação à profissão:

“No meu caso, apenas uma gerenciadora de conflitos.” (Professora de História);

"Ser professora é uma dádiva e um fardo, constantemente nos deparamos com situações deliciosas como um abraço inesperado ou um aprendizado significativo das crianças, entretanto, há momentos em que você se sente impotente, e cansada das cobranças da sociedade e daqueles que não valorizam seu trabalho." (Estagiária em educação) $e$

“Ser vida loca.” (Filha de professores)

$\mathrm{Na}$ primeira resposta, elaborada pela professora de História, o uso da expressão "apenas" permite notar a existência de um certo descontentamento da docente com o fato de não conseguir realizar com seu trabalho, nada mais do que disciplinar ou lidar com as desordens que ocorrem na sala de aula. No segundo caso, trata-se de uma aluna jovem, que se apresentou no início do questionário como estagiária, mas sua resposta aponta que ela já se identificava como professora no momento da pesquisa ${ }^{15}$. Seu registro acerca do que é ser professor manifesta a satisfação em promover a formação de seus alunos, mas ao mesmo tempo, critica a falta de valorização e o excesso de cobranças que recaem sobre os professores. Por fim, a última resposta foi a de uma estudante jovem, filha de professores, cujo registro deu margem a dois tipos de interpretação. Se interpretado simplesmente como "vida louca", a resposta poderia indicar que ser professor envolve um cotidiano intenso, repleto obstáculos e obrigações. Por outro lado, se a resposta for examinada sob o ponto de vista da gíria popular "vida loka", o sentido da mesma indicaria viver sem regras, em situações de aventura e perigo. De qualquer maneira, independente da resposta da formanda ter como sentido alguma das duas interpretações, há entre as três respostas a perspectiva partilhada de manifestar a concepção de que ser professor envolve certamente a vivência de algum tipo de dificuldade.

A respeito das perspectivas profissionais dos respondentes da FEUSP, quinze alunos, entre cinquenta e cinco respondentes, indicaram ter interesse exclusivamente no exercício do magistério, principalmente em estabelecimentos públicos $(8 / 15)^{16}$. Outros vinte e cinco alunos

\footnotetext{
${ }^{15}$ Como sabemos, mesmo sendo uma prática irregular, há escolas particulares que atribuem a estagiários do ensino fundamental, turmas de alunos para que os mesmos as conduzam sozinhos, na condição de "professores". Aqui, podemos ter um desses casos.

${ }^{16}$ Somente três alunos desejam atuar apenas em escolas particulares, enquanto 4 alunos se mostraram indiferentes em relação ao tipo de estabelecimento.
} 
desejavam seguir na profisssão (25/55), seja na condição de professores ou desempenhando atividades outras no âmbito da educação. Assim, aproximadamente sete em cada dez alunos previam a atuação no magistério como uma possibilidade de atividade profissional. Por outro lado, onze alunos não pretendem atuar na docência (11/55), possuindo os mesmos a perspectiva de trabalhar em cargos ou funções na administração escolar (5/11) (direção ou coordenação pedagógica); em contextos diversificados tais como hospitais, organizações não governamentais, empresas privadas e museus (3/11) ou se dirigirem para a área acadêmica (3/11). Somente um aluno afirmou o desejo de não atuar na educação (1/55), enquanto três respondentes se mostraram abertos a permanecerem na área ou desenvolverem qualquer outra atividade, mesmo não sendo no âmbito da educação.

As expectativas profissionais dos respondentes demonstraram que a pretensão de atuar na área educacional se deu mesmo entre aqueles que não tinham o curso de Pedagogia como sua primeira opção formativa. Para pelo menos quinze alunos que não tinham a Pedagogia em seus planos iniciais (15/36), identificou-se que o estágio contribuiu para produzir nos mesmos um interesse pela profissão antes não existente, além de auxiliá-los na identificação de afinidades e interesses profissionais:

"Entrei no curso pensando em seguir carreira acadêmica (pesquisa e docência no ensino superior), durante os estágios me apaixonei pelo trabalho com as crianças e pretendo trabalhar na pré-escola ou nas séries iniciais do Ensino Fundamental.”;

"Fiz estágio em educação infantil e não me identifiquei com a faixa etária. Percebi que me interessava mais por gestão escolar.";

“Permitiu-me conhecer uma área nova para mim, o ensino bilíngue.”; e

“Sim, pela experiência adquirida com alunos especiais.”

No caso dos alunos que tinham a Pedagogia como sua primeira opção, a prática do estágio também foi útil no sentido de confirmar o acerto da decisão tomada:

“Antes de fazer estágio eu não tinha certeza se eu iria dar aula. Eu sabia que fazendo pedagogia você tinha outras opções. Mas eu gostei muito de estar na sala de aula, além de entender depois que essa vivência é importante pra quem está na área de educação."; $e$

“Continuo com foco em trabalhar em escola como professora ou coordenadora.”

Somente três alunos declararam que o estágio produziu reações de desinteresse pela profissão. Em suas falas, é possível identificar um certo desapontamento em relação à distância 
de uma organização escolar idealmente organizada e a realidade das escolas onde desenvolveram a prática do estágio:

"Hoje tenho certeza de que não serei funcionária pública estadual, tampouco municipal devido às péssimas condições de trabalho.";

“Afastou-me da escola.”; $e$

"Pensei em desistir. A realidade tanto particular quanto pública é muito aquém do que aprendemos na faculdade sobre educação.”.

Indagados a respeito da continuidade de seus estudos após a conclusão do curso de pedagogia ${ }^{17}$, obteve-se a informação que quatro em cada cinco alunos desejam dar início a estudos na pós-graduação em educação nas modalidades stricto sensu (30/56) e lato sensu (16/56). Houve casos em que os respondentes demonstraram a perspectiva de continuidade dos estudos por meio da frequência a novos cursos de graduação (7/56). Tal decisão, porém, para quatro desses estudantes não tem relação com o desejo de abandonar a área educacional, uma vez que suas escolhas envolveram novos cursos de licenciatura (licenciatura em Geociências; Educomunicação; Artes ou Geografia) e bacharelado em Gestão de Políticas Públicas, tendo em vista o interesse da respondente em atuar na área de políticas públicas educacionais.

Enquanto dois alunos manifestaram o desejo de cursar novas graduações, mas sem que se desse a indicação do curso escolhido, somente um aluno expressou de fato o interesse em mudar de área, uma vez que o novo curso escolhido foi Medicina. Essa aluna teve na Pedagogia sua primeira opção formativa e afirmou que sua escolha se deu por gostar da profissão e de crianças ("Gosto muito da profissão e amo lidar com as crianças”). De qualquer modo, apesar da estudante ambicionar uma nova área formativa, ela não excluiu a possibilidade de exercer o magistério após a conclusão do curso. De maneira geral, a associação das perspectivas profissionais, as quais demonstraram o desejo de permanência na profissão, aliada à forte expectativa de continuidade dos estudos na área, indicam que os respondentes investigados, mesmo os que não tinham a Pedagogia como sua primeira opção formativa, nutriam no último ano do curso uma forte adesão ao magistério.

A intencionalidade pelo exercício da docência entre os alunos ingressantes do curso de Pedagogia da FEUSP havia sido investigada por Leme (2012) no ano de 2010. Como resultado, a autora identificou que 30\% dos alunos ingressaram no curso sem a perspectiva de exercer o magistério. Em sua análise, a própria universidade, ao oferecer a oportunidade de

\footnotetext{
${ }^{17}$ Somente três respondentes informaram que não pretendem estudar após o encerramento do curso.
} 
ingresso na área acadêmica, cria um elemento de concorrência com a docência na educação básica, principalmente entre os cursistas de licenciatura em Física e Matemática.

No caso dos formandos aqui investigados, somente um aluno concluirá o curso sem a perspectiva de permanecer na área educacional. Os demais, mesmo que recusando sua inserção em sala de aula (11/55), demonstraram a expectativa de atuação na área educacional, dado que não indica necessariamente a falta de engajamento com a profissão, mas sim o conhecimento da multiplicidade de áreas de atuação que o curso proporciona. Esse modo de análise do envolvimento dos alunos com a profissão pode ser confirmado pelos dados levantados nesta pesquisa, diante da constatação da recusa dos alunos em assinalarem respostas que ofereciam aos mesmos a chance de demonstrarem seu desapreço pelo curso e pelas atividades profissionais que dele decorrem, tais como a perspectiva de não atuar na área, procurar por um novo curso de formação profissional e evitar a formação na pós-graduação voltada para a especialização dos mesmos na área educacional. Tal como foi demonstrado, entre os respondentes da FEUSP, essas possibilidades foram indicadas por somente três alunos, frente um universo de cinquenta e cinco.

O estudo do perfil dos respondentes último anistas da FEUSP indicou alguns aspectos que os particularizam. O primeiro ponto diz respeito ao fato de parte significativa desses estudantes ingressarem no curso de Pedagogia como uma segunda opção formativa, ou seja, depois de já terem iniciado outro curso ou concluído outra graduação. O segundo aspecto tem relação com o fato da origem social desses agentes ser menos desprivilegiada que a de outros cursos de formação de professores (Matemática e Física) dessa mesma universidade. Assim, uma boa parte dos respondentes teve a oportunidade de estudar em escolas privadas, em dedicação exclusiva, além de seus pais possuírem formação universitária e rendimentos financeiros não excessivamente restritivos. Não deve ser desconsiderado, porém, o fato de praticamente metade dos alunos, ao ingressarem no ensino superior, terem superado o nível de instrução paterno, enquanto mais da metade superou o nível formativo de suas mães.

Em termos de atividades culturais, notou-se o peso da origem social dos mesmos no empobrecimento de suas práticas, que indicaram a preferência por aquelas realizadas no ambiente doméstico. Entre essas, destacou-se o hábito da leitura por sua frequência elevada, a qual se deteve principalmente na apreciação de romances estrangeiros que figuravam nas 
listagens dos mais vendidos. Os jornais e revistas, por sua vez, foram pouco consultados e, na ocorrência de leitura dos mesmos, verificou-se a preferência pelos periódicos de maior circulação e popularidade (Veja, Nova Escola, Folha de S. Paulo e Estado de S. Paulo). No que se refere às práticas de lazer não domiciliares, verificou-se que o cinema foi a mais comumente realizada e, assim como emergiu nas práticas de leitura, novamente se manifestou o favoritismo pelas produções de caráter massificado. Por fim, vale ressaltar que foram identificadas demonstrações dispersas de práticas culturais legitimadas, evidenciando a modesta familiaridade dos mesmos com a cultura portadora de maior valor social, além de uma fraca disposição no sentido de converter o capital cultural em outros que lhes favorecessem na melhora ou manutenção de suas posições na estrutura social.

Foi relevante nesse grupo de respondentes a presença de licenciados e bacharéis que procuravam no curso de Pedagogia satisfazer seus interesses profissionais. No caso dos primeiros, foi perceptível a intenção pelo aperfeiçoamento formativo e pela ampliação de suas oportunidades de trabalho no âmbito da administração escolar. Entre os bacharéis, as expectativas abrangiam o desejo de mudança de área de atuação profissional e a ampliação das suas chances de atuação no mercado de trabalho. Foi constatado também que a escolha profissional, mesmo quando objetivamente determinada, envolveu justificativas de ingresso na carreira associadas ao sentido fundamental do trabalho de um pedagogo, isto é: o interesse pelas questões de ensino; pela função social e política do trabalho; e pelos conteúdos que envolvem o domínio de conhecimentos específicos da profissão, os quais também estavam presentes nas representações acerca da função docente. 


\section{SER DIFERENTE EM MEIO AOS IGUAIS: A SEGMENTAÇÃO DOS CURSISTAS A PARTIR DO RECORTE INSTITUCIONAL}

\subsection{SENSO PRÁtICO COMO SENTIDO DO JOGO: RELAÇÕES ENTRE A INSTITUIÇÃO UNIVERSITÁRIA, OS PLANOS FORMATIVOS E O PERFIL SOCIOECONÔMICO DOS FORMANDOS INVESTIGADOS}

A origem social dos professores das séries iniciais já foi identificada e discutida em estudos diversos acerca dos agentes que terminam por se dedicar à docência. Pereira (1969), em pesquisa desenvolvida na década de 1960, com professoras do ensino fundamental, normalistas e suas formadoras observou que as mesmas provinham de famílias de classe média. Já Gouveia (1970, p. 32), em pesquisa realizada no ano de 1960 com estudantes da escola normal, constatou que o interesse pelo magistério ocorria principalmente entre a "classe trabalhadora e nos escalões inferiores das classes médias". Em estudo a respeito dos valores do magistério paulista na década de 1980, Pereira (2001, p. 46) reafirma a localização dos professores primários, situados nas "posições mais baixas do espaço social", os quais vislumbravam no trabalho docente a oportunidade de "superação do trabalho manual, o destino quase inevitável dos agentes situados nas mesmas posições.” (p. 47), enquanto os professores originários dos setores médios reivindicavam constantemente a superação dos fatores que promoviam a desvalorização da profissão. A coexistência desses dois setores sociais (camadas médias e camadas baixas) no âmbito da docência também foi notada por Pessanha (1994), que a justificou por meio da ocorrência de um processo crescente de pauperização desses profissionais. Assim, inicialmente desempenhada pelas camadas médias, diante da progressiva desvalorização social do trabalho docente, deu-se um processo de inserção das camadas mais baixas no desempenho da profissão.

Estudos contemporâneos (UNESCO, 2004; BIANCHINI, 2005; CRUZ, 2008; PENNA, 2011; KOGA, 2013) indicam a manutenção desse perfil entre os professores, os quais possuem sua origem social claramente associada às camadas populares. Do mesmo modo, pesquisas dedicadas ao estudo dos agentes sociais que procuram os cursos de licenciatura para a formação de professores das séries iniciais (PEREIRA, 2006; GATTI e BARRETO, 2009; LOUZANO et. al., 2010; LEME, 2012) identificam, tal como esperado, a perpetuação da mesma condição social de origem presente entre os que já atuam na profissão. De modo geral, 
a descrição desse alunado é elaborada de modo genérico, por meio de uma caracterização homogeneizadora do público que se dirige ao curso de Pedagogia. Contudo, o exame do perfil socioeconômico dos estudantes do curso de Pedagogia associado a diferentes instituições formativas, tal como se propõe nesta investigação, permitiu a identificação de variações entre os respondentes, as quais serão apresentadas a seguir.

Considerando o perfil popular, com interesses mercadológicos e pouco seletivo da Universidade Bandeirante Anhanguera, foi possível notar que essa instituição terminou por abranger os respondentes - dentre as quatro instituições investigadas - portadores das condições socioeconômicas menos privilegiadas. Trata-se do grupo de alunos detentor do menor volume de renda familiar per capita mensal e, apesar do valor da mensalidade da instituição ser reconhecido por seu baixo custo, as limitações econômicas vivenciadas por esses estudantes fizeram com que boa parte dos mesmos tivessem de recorrer a auxílios financeiros para o custeio de sua formação. Em termos do nível de escolaridade familiar, observa-se que os mesmos pertencem a famílias portadoras de baixo capital cultural, uma vez que seus pais atingiram como nível de formação mais elevado o ensino fundamental completo. Em decorrência dessa formação escolar, os mesmos desempenham atividades ocupacionais predominantemente identificadas ao trabalho manual. A trajetória formativa dos respondentes também carrega marcas de sua posição pouco privilegiada na estrutura social, uma vez que os mesmos são egressos de instituições públicas, enquanto o ensino médio foi cursado no período noturno por uma parte significativa dos estudantes, os quais tiveram de conciliar seus estudos com o desenvolvimento de atividades remuneradas. Por fim, a faixa etária dos alunos da UNIBAN-Anhanguera é a mais elevada dentre todos os grupos (próxima dos 31 anos ou mais), indicando uma espera significativa para o início de seus estudos superiores.

Em meio às demais instituições, os respondentes da UNIFESP são os que mais se aproximam do perfil socioeconômico dos alunos vinculados à UNIBAN-Anhanguera. A renda per capita mensal é levemente superior, associada à faixa de um a até dois salários mínimos, entretanto a ocupação profissional desenvolvida pelos pais também está mais fortemente relacionada ao trabalho manual. Em termos de formação escolar, entretanto, nota-se a presença de genitores que concluíram o ensino médio e superior, mesmo que o número de portadores do diploma do ensino fundamental ainda seja significativo. Os respondentes, por sua vez, concluíram sua formação predominantemente em instituições públicas de ensino, enquanto o ensino médio noturno associado ao desempenho de alguma ocupação remunerada, ocorreu somente para menos da metade dos alunos investigados. Em termos etários, os alunos da 
UNIFESP são mais jovens que os estudantes da UNIBAN-Anhanguera, sendo a faixa etária de destaque aquela situada entre os vinte e vinte e cinco anos de idade, havendo uma interrupção menor entre a finalização do ensino médio e o início do curso superior.

A observação dos dados socioeconômicos dos respondentes da UNIFESP, quando comparados aos formandos investigados da UNIBAN-Anhanguera, indica que os primeiros possuem condições sociais de origem levemente superiores em relação aos últimos: são alunos mais jovens, detentores de mães mais escolarizadas, que trabalharam no ensino médio em menor proporção e suas famílias atingiram níveis de renda pouco mais elevados. Entretanto, é relevante o fato da existência de uma correspondência maior entre os perfis do estudantes das duas instituições, quando se considera os formandos do curso de Pedagogia da UNIBANAnhanguera (cujo curso de Pedagogia era ministrado exclusivamente no período noturno) e os formandos do curso de Pedagogia noturno da UNIFESP. No caso dessa última instituição, trata-se de um turno formativo que conta com maior número de alunos negros, egressos de escolas públicas e portadores de uma faixa de renda mais baixa. A faixa etária dos mesmos é mais elevada e seus pais são menos escolarizados que os dos estudantes do período diurno da mesma instituição.

O perfil socioeconômico dos respondentes da UNIBAN-Anhanguera e UNIFESP demonstrou a existência de proximidades que certamente estão relacionadas aos objetivos institucionais que permeiam ambas universidades, qual seja, o de promover o atendimento das classes populares no âmbito do ensino superior. Por outro lado, os dados que oferecem informações acerca da origem social dos estudantes indicam a ocorrência de similaridades entre os respondentes da FEUSP e PUC-SP, os quais partilham condições sociais e econômicas mais favoráveis.

Os respondentes vinculados à Pontifícia Universidade Católica de São Paulo compõem o grupo que possui as melhores condições socioeconômicas dentre as quatro instituições investigadas. São alunos cujas famílias dispõem de níveis mais elevados de renda per capita e seus genitores possuem predominantemente formação universitária, desempenhando atividades profissionais correlatas ao grau de escolaridade obtido. Em termos de faixa etária, são alunos jovens, que ingressaram na universidade no período de até um ano após o encerramento do ensino médio, sendo esse concluído em escolas particulares em condição de dedicação exclusiva aos estudos. Há que se destacar o fato de existir nesse grupo, alunos que não usufruíam de condições sociais tão privilegiadas, os quais cursavam a graduação no período noturno. Trata-se de uma parcela de estudantes que estudaram em escolas públicas e 
trabalharam durante o ensino médio, ao mesmo tempo que a renda familiar tendeu a níveis mais baixos, assim como o grau de escolaridade de seus pais. Por fim, pertence a esta parcela de estudantes os detentores de bolsas de estudo ou beneficiários de programas de financiamento estudantil, tendo em vista o custeio das mensalidades do curso.

A proximidade da origem social entre os alunos investigados na FEUSP e PUC-SP ocorre, sobretudo, quando se consideram os estudantes que frequentaram o curso de Pedagogia no período vespertino. Essa observação se faz necessária pelo fato das condições econômicas e sociais dos alunos sofrerem variações de acordo com o turno no qual o estudante cursou a maior parte da sua graduação. No caso dos respondentes da FEUSP, os alunos do período vespertino reúnem condições econômicas e formativas, tanto de cunho pessoal, quanto familiar, levemente mais favorecidas em relação aos formandos do período noturno. De modo geral, a renda se mostra mais elevada no período vespertino, do mesmo modo que há mais genitores universitários nesse turno. Ainda no vespertino, se fizeram mais presentes os alunos que estudaram em escolas particulares durante o ensino médio e que não tiveram necessidade de trabalhar durante esse período formativo.

O exame do perfil socioeconômico dos formandos investigados nas quatro instituições permitiu identificar a existência de aproximações entre os respondentes da UNIBANAnhanguera e UNIFESP, enquanto os alunos da PUC-SP e FEUSP apresentam maiores semelhanças entre si. No caso das duas primeiras instituições, a proximidade dos perfis socioeconômicos podem ser justificados por uma clara intencionalidade das universidades em abranger alunos portadores de condições sociais desprivilegiadas. A FEUSP e a PUC-SP possuem em comum o seu tradicionalismo e o reconhecimento externo de sua excelência formativa. Dessa maneira, no caso da FEUSP, apesar da nota de corte no vestibular não ser elevada, ela ainda assim seleciona o seu alunado, atraindo para si um público com características socioeconômicas não tão limitadas. A PUC-SP, a seu turno, aproxima estudantes que possuem condições financeiras de custear uma formação onerosa, os quais geralmente pertencem a famílias dotadas de melhores condições sociais e econômicas. São estudantes que tentaram ingressar em universidades públicas e, diante de reprovação, justificaram sua "escolha" institucional pela "qualidade do curso" e pelo "conceito de que desfruta como universidade/faculdade"1. Entre os respondentes da PUC-SP, portanto, nota-se a existência de

\footnotetext{
${ }^{1}$ As informações sobre a tentativa de ingresso em universidade pública e as justificativas empregadas para a escolha da PUC-SP como instituição para a realização do curso de Pedagogia foram obtidas por meio do acesso
} 
uma certa preocupação com a qualidade do curso, ainda que o acesso ao mesmo exija um elevado investimento financeiro.

Enquanto Bourdieu (2013) destaca a ausência de intencionalidade deliberada na conduta dos agentes sociais, as disposições constitutivas do habitus orientam suas ações a partir das condições objetivas de vida experimentadas pelos mesmos durante seu processo de socialização. Consequentemente, dá-se um ajustamento das formas de pensar e agir desses atores às suas condições sociais de origem, engendrando práticas e decisões razoáveis no âmbito das condutas esperadas no interior dos grupos sociais que partilham da mesma condição de classe.

Nesse sentido, escolher cursar a graduação em Pedagogia seja na UNIBANAnhanguera, UNIFESP, PUC-SP ou FEUSP, depende do meio social de origem desses agentes. O volume global dos capitais detidos torna possível a participação não intencionalizada dos atores sociais, de modo mais ou menos efetivo, nos jogos em que as estratégias de escolarização favorecem a reprodução da posição ocupada pelos mesmos no interior da estrutura social (BOURDIEU, 1994). Quanto maior a importância da formação escolar no sentido de conservar ou melhorar a posição social ocupada pelos agentes, mais amplos serão os investimentos educacionais e o valor atribuído ao processo formativo institucionalizado:

As atitudes dos membros das diferentes classes sociais, pais ou crianças e, muito particularmente, as atitudes a respeito da escola, da cultura escolar e do futuro oferecido pelos estudos são, em grande parte, a expressão do sistema de valores implícitos ou explícitos que eles devem à sua posição social. (...) Compreende-se por que a pequena burguesia, classe de transição, adere mais fortemente aos valores escolares, pois a escola lhe oferece chances razoáveis de satisfazer a todas suas expectativas, confundindo os valores do êxito social com os do prestígio cultural. (BOURDIEU, 2013, p. 48)

Daí decorre a percepção da importância da qualidade do curso a ser frequentado e do prestígio institucional, os quais adquirem relevância entre os agentes mais habilidosos no reconhecimento do sistema educacional universitário e de sua hierarquização, variável de acordo com o volume global do capital econômico, cultural e social dos agentes sociais envolvidos. $\mathrm{O}$ acesso a uma instituição particular e prestigiosa como a PUC-SP, por exemplo, tende a se tornar restrito a um pequeno grupo de pessoas que possuem níveis de renda e capital cultural mais elevados. Porém, no caso dos alunos bolsistas, mesmo na ausência do capital econômico, nota-se que seus pais possuem níveis formativos mais elevados (associados ao de 2008 e 2010. Os dados foram disponibilizados pela Coordenadoria de Vestibulares e Concursos da PUC-SP. 
ensino médio e superior) que os detidos pelos genitores dos estudantes da UNIBANAnhanguera (ensino fundamental). Essa formação cultural certamente atuou como favorecedora de um processo de escolha institucional guiada pela procura daquela que fosse capaz de proporcionar um diploma portador de maior valor simbólico.

Por outro lado, os agentes pertencentes a famílias menos escolarizadas e detentoras de uma condição econômica limitada tendem a guiar suas escolhas a partir de fundamentos de ordem prática, que envolvem a proximidade da residência ou do local de trabalho; o valor da mensalidade e o tempo de dedicação ao curso tendo em vista a conclusão do mesmo, mantendo um estilo de vida marcado pelas pressões materiais. Entre os respondentes da UNIBANAnhanguera observou-se que a escolha da instituição foi justamente guiada por tais princípios, tais como o valor popular da mensalidade, além do curso de graduação ter duração máxima de três anos. Assim, a possibilidade de concluir o curso em menos tempo significou para essas alunas menor gasto financeiro, ante o objetivo de possuir um diploma universitário, além de significar uma inserção mais rápida no mercado de trabalho. Outro aspecto prático diz respeito à ausência de um vestibular seletivo, que tornou possível o ingresso no ensino superior de alunas com sérias lacunas formativas, as quais seriam suficientes para impedir o acesso das mesmas em todas as outras instituições aqui examinadas. Além disso, das vinte alunas investigadas, dezoito moram na mesma região em que o campus universitário estava localizado.

Entre os alunos da UNIFESP, porém, o perfil econômico dos mesmos está abaixo dos formandos da PUC-SP e FEUSP, ao mesmo tempo que supera a renda per capita familiar dos respondentes da UNIBAN-Anhanguera e o nível formativo familiar, colocando-os em uma posição intermediária em termos de capital econômico e cultural. Essa variação na posse desses dois capitais atuou de modo diferenciado nas suas estratégias formativas, fazendo com que os mesmos abrissem mão de critérios práticos, tal como a localização da universidade - que envolve gasto financeiro e tempo de deslocamento - em função do valor simbólico infundido no fato de frequentar uma universidade pública como a UNIFESP.

A observação dos bairros ocupados pelos estudantes da UNIFESP indicou que dos cinquenta e cinco respondentes, onze moravam em Guarulhos, ou seja, no município em que o curso de Pedagogia é ministrado. Outros onze estudantes moravam em bairros da zona leste de São Paulo, ou seja, na divisa com o município de Guarulhos, enquanto os trinta e três alunos restantes viviam em localidades significativamente distantes da instituição. De acordo com as respostas dos alunos, a dificuldade de acesso à universidade foi apresentada como uma das principais queixas em relação ao período no qual transcorreu seu processo formativo. 
Dependentes do transporte público, mesmo os estudantes que viviam no município de Guarulhos ou em bairros da zona leste relataram despender no mínimo uma hora do seu tempo para chegar na universidade e voltar para a sua residência. Nos demais casos, trinta e dois alunos relataram gastar entre duas e duas horas e meia de tempo na realização desse mesmo trajeto. Ainda assim, mesmo considerando os custos financeiros e as longas horas consumidas com o deslocamento diário, estes formandos vislumbraram ganhos na "escolha” institucional por eles efetivada. Trata-se de uma postura que demonstra a posse de uma devoção cultural e uma disposição ascética, presente nos quadros médios, originários das camadas populares, que partilham da crença na ascensão social via formação escolar (BOURDIEU, 2007).

As frações de classe são portadoras de um habitus que as representa, cujas disposições estão ajustadas a uma determinada posição na estrutura de classes. $\mathrm{O}$ volume e a estrutura dos capitais detidos agem sobre a composição do habitus que indica aos agentes suas chances de ingresso em uma dada instituição e os ganhos simbólicos envolvidos nessa ação. A parcela dos agentes sociais detentores de maior volume de capital cultural em relação ao capital econômico, por sua vez, tendem a avistar na escolarização um meio de manutenção ou de ascensão social.

O ingresso em um determinado estabelecimento universitário ocorre, portanto, a partir da retenção por parte de seus cursistas de certos recursos culturais e econômicos. A variação na posse do volume desses capitais faz com que suas escolhas sejam guiadas, em alguns casos, por limitações de ordem objetivas - promovendo uma distribuição desigual das oportunidades escolares quanto mais desfavorecidos forem os agentes. Ou ainda, por estratégias de reprodução via formação escolar, circunstância esta em que o investimento cultural na busca por um diploma passa a considerar os ganhos reais e simbólicos envolvido na posse do mesmo.

O diploma como um bem simbólico constitui um elemento de distinção no interior de um jogo em que as classes sociais procuram se distanciar dos grupos detentores de um poder concorrencial mais próximo e imediato. Trata-se de uma luta simbólica travada entre as classes que, por meio da raridade de suas práticas e posse de bens exclusivos, no caso o ingresso em uma determinada universidade e a posse futura de seu diploma, passam a ocupar posições diferenciadas no interior na estrutura social. Tais agentes partilham a crença no valor da cultura no âmbito de uma luta em que se disputa a ascensão social. Essa disputa, por sua vez, é produtora da relevância cultural e da necessidade de apropriação da mesma, fazendo dos adversários cúmplices, uma vez que aceitaram participar do jogo, ao mesmo tempo que promovem a própria dinâmica do campo social (BOURDIEU, 2007). 
O levantamento realizado na pesquisa acerca dos planos formativos dos respondentes após o término do curso de Pedagogia indicou a permanência do interesse dos mesmos na continuidade de seus estudos, sendo mais uma vez notabilizada a presença de "um ethos de ascensão social e de aspiração ao êxito na escola e pela escola" (BOURDIEU, 2013, p. 48). O caráter da formação, porém, sofreu variações de acordo com o perfil institucional ao qual os respondentes estavam vinculados. Assim, entre as universidades públicas a perspectiva de aproximadamente metade dos estudantes residiu na realização de pesquisas no âmbito do mestrado (FEUSP 30/56; UNIFESP 27/51), enquanto entre as universidades privadas o interesse se voltou para a frequência a cursos de especialização (UNIBAN-Anhanguera 14/20; PUC-SP 14/25). No caso das instituições privadas deve ser destacado o fato de nenhum respondente da UNIBAN-Anhanguera considerar o ingresso em um programa de mestrado, enquanto na PUC-SP seis estudantes projetaram essa possibilidade.

O estudo das perspectivas formativas dos respondentes investigados indica, portanto, a força da ação institucional no estabelecimento de planos futuros de seus cursistas. As universidades que se comprometem com a titulação do seu corpo docente e com a valorização da pesquisa terminam por apresentar aos alunos uma nova possibilidade de investimento formativo e de atuação profissional. Leme (2012), por exemplo, identificou entre os licenciandos de Física e Matemática da USP um forte interesse pelo universo da pesquisa, consequência de uma possibilidade de atuação vigorosamente apresentada pela instituição aos alunos. Por outro lado, entre os respondentes da UNIBAN-Anhanguera, nota-se a ausência total dessa perspectiva formativa, claramente associada ao fato da instituição não ter por característica a produção científica, mas sim o atendimento das demandas do mercado de trabalho.

O fato da instituição ter tradição no campo da pesquisa não inibiu a perspectiva de parte dos seus alunos de frequentar cursos de especialização tendo em vista o aprofundamento de sua formação profissional. Desconsiderando a modalidade da pós-graduação, se stricto ou lato sensu, a somatória dos alunos que desejam prosseguir estudando após o término do curso é extremamente alta nas quatro instituições: na FEUSP, UNIFESP e PUC-SP, oito em cada dez alunos desejavam dar continuidade aos estudos, enquanto na UNIBAN-Anhanguera, sete em cada dez respondentes possuíam essa expectativa.

O desejo pela continuidade dos estudos entre os alunos dos cursos de graduação também foi identificado por Almeida (2012), ao investigar alunos bolsistas participantes do Programa Universidade para Todos (PROUNI) de instituições privadas paulistas. De acordo 
com o autor, o diploma de graduação não era visto pelos bolsistas como suficiente, já que a competitividade do mercado de trabalho exigia uma formação diferenciada para aqueles que procuravam por uma oportunidade de atuação profissional e entre os que já atuavam e desejavam manter o emprego conquistado. Ao mesmo tempo, Almeida observa que as universidades particulares, desejosas pela ampliação dos seus lucros, oferecem aos seus alunos diversas possibilidades formativas no âmbito da pós-graduação, tendo em vista ampliar a permanência dos mesmos como alunos pagantes, por meio do convencimento acerca da importância da formação continuada.

Retomando Bourdieu (1996, p. 21), o espaço social é construído a partir da distribuição dos agentes de acordo com a estrutura do seu capital, ou seja, o peso relativo do capital cultural e econômico. Esse espaço é retraduzido em um espaço de disposições, ou seja, do habitus. Assim, "a cada classe de posições corresponde uma classe de habitus", produzidos pelos condicionamentos sociais de origem dos agentes e que organiza suas práticas e representações, portanto, as suas decisões. Quanto mais próximos os agentes estão no espaço social, mais parecidas serão as suas condutas, seus esquemas classificatórios (bom x mau; distinto x vulgar), enfim, sua forma de estar no mundo, reproduzindo propriedades do seu grupo social.

O fato de uma parcela significativa dos respondentes desejarem a continuidade dos estudos indica a proximidade dos mesmos no interior do espaço social e a partilha de modos de ação e pensamento que refletem as marcas de sua posição social. Esses jovens agem e planejam seu futuro (desejo de fazer uma pós-graduação) de acordo com um senso prático, estruturado desde a sua infância, por meio do qual se dá o reconhecimento espontâneo das estratégias mais seguras e rentáveis, sem que se dê, entretanto, qualquer tipo de cálculo consciente e racional, tendo em vista a ampliação do seu sucesso formativo e profissional e, consequentemente, sua reprodução social.

Para a promoção da ascensão ou manutenção da posição social ocupada, os dados coletados nesta pesquisa e por Almeida (2012), indicam que o curso de graduação já não é mais suficiente. De acordo com Bourdieu (2013), o valor dos títulos escolares varia em função de sua oferta: quanto mais facilitado for o acesso a um determinado curso superior ou titulação, menos valor ele terá no mercado simbólico, num processo de inflação das qualificações acadêmicas ou dos títulos escolares. Assim, com a democratização do acesso ao ensino superior, as frações de classe intensificaram suas buscas pelo capital cultural autenticado pela universidade no âmbito da pós-graduação, uma vez que nas relações entre diplomados e 
empregadores "os vendedores da força de trabalho têm uma força tanto maior quanto mais importante for seu capital escolar (...)" (BOURDIEU, 2013, p. 134).

O interesse pela pós-graduação, portanto, consiste em uma tentativa de tornar mais rara a formação adquirida no meio universitário, tendo em vista converter o capital cultural em outros que favoreçam uma melhor posição do agente no âmbito da estrutura social. Trata-se de uma luta travada entre as classes, que promove uma demanda contínua por novos cursos e formações, numa busca incessante pelos títulos escolares. Como consequência, o crescimento no número de portadores dessas novas qualificações promove a desvalorização daqueles que as possuem. Assim, quanto mais os alunos procuram pelos cursos de pós-graduação, um novo desprestígio se concretiza: “A dialética da desvalorização e recuperação (ou desclassificação e reclassificação) tende, assim, a nutrir-se a si própria." (BOURDIEU, 2013, p.171)

\subsection{AS UNIVERSIDADES E O PERFIL SOCIOCULTURAL DOS FORMANDOS INVESTIGADOS: PROXIMIDADES E DISTANCIAMENTOS}

Como parte do estudo acerca do perfil dos formandos das quatro universidades investigadas, foi realizado um levantamento das práticas culturais desenvolvidas pelos mesmos. Entre os resultados obtidos observou-se a existência de proximidades e distanciamentos entre os estudantes das quatro instituições os quais serão abordados a seguir.

De modo geral, verificou-se que as atividades culturais mais frequentes e comuns aos respondentes das quatro universidades foram: acessar a internet, assistir televisão, ler e ouvir música. $\mathrm{O}$ acesso à internet obteve índices elevados, abrangendo praticamente a totalidade dos alunos participantes da pesquisa na PUC-SP, FEUSP e UNIFESP. Na UNIBAN-Anhanguera o acesso frequente abarcou mais da metade dos alunos (14/20), porém o maior número de respondentes que declararam raramente fazer uso da rede se encontra nessa instituição $(06 / 20)$. O cruzamento da frequência de acesso com o local de utilização da internet permitiu identificar que o baixo consumo está associado aos alunos que não possuem acesso facilitado, uma vez os mesmos informaram utilizá-la a partir de centros públicos, domicílios de conhecidos, do trabalho e da universidade. Esse quadro não se repete em nenhuma outra instituição, havendo preponderância das consultas realizadas em aparelhos eletrônicos móveis (sobretudo na PUCSP) e nas residências dos formandos investigados.

A prática de leitura dos respondentes indicou de modo recorrente a preferência pelos livros, em detrimento dos periódicos. O levantamento do último livro lido apontou o interesse 
pela literatura estrangeira, com destaque para os best-sellers. Em termos de especificidades institucionais, verificou-se que os respondentes da PUC-SP, FEUSP e UNIFESP tiveram mais facilidade para indicar o nome das suas últimas leituras, além dos mesmos citarem, mesmo que em menor proporção, livros especializados em História, Filosofia, Linguagem, Antropologia, entre outros temas, demonstrando a existência nessas instituições de leitores dotados de um gosto marcado por um certo ecletismo cultural. Por fim, FEUSP e UNIFESP se destacaram pela ocorrência da citação de obras clássicas da literatura, bem como autores contemporâneos que partilham de maior reconhecimento da crítica literária.

O interesse por periódicos, por sua vez, foi extremamente baixo em todas as universidades. Diante do pedido de informarem os nomes das publicações que costumavam ler, deu-se a recorrência da indicação de revistas e jornais mais populares e que contam com um grande número de vendas (revistas Veja e Nova Escola; jornais Folha de S. Paulo e Estado de S. Paulo). Por outro lado, alguns dos respondentes da PUC-SP, FEUSP e UNIFESP mencionaram a leitura de jornais internacionais e revistas que contam com menor inserção no mercado das publicações periódicas, portadores de conteúdo mais denso, crítico, literário ou tendencialmente alinhados à esquerda (Adital, Carta Maior, Le Monde Diplomatique, Caros Amigos, CartaCapital, Brasileiros, Piauí). Revistas especializadas em cinema, esportes e turismo também tiveram uma pequena ocorrência, sobretudo entre os respondentes da PUC-SP e UNIFESP.

A assistência à televisão demonstrou uma preferência geral pela programação de entretenimento, com destaque para os filmes, séries e programas de variedades. No que se refere ao gosto musical, obteve a liderança nas menções dos respondentes das quatro universidades a Música Popular Brasileira (MPB). Esse gênero foi seguido na USP e UNIFESP pelo rock, enquanto na UNIBAN-Anhanguera e PUC-SP o segundo gênero mais mencionado foi o sertanejo.

O uso do tempo livre para descansar e cuidar da casa foi significativamente declarado pelos respondentes da UNIBAN-Anhanguera, UNIFESP e USP, enquanto na PUC-SP houve destaque das atividades de visitação a parques, idas ao cinema e realização de viagens. $\mathrm{O}$ cruzamento dos bairros de moradia dos alunos da PUC-SP com a circulação nos parques mostrou a existência de associação entre a intensificação das visitas e estudantes que moram em regiões contempladas com parques públicos.

Os dados retomados até o momento mostram que os respondentes das universidades investigadas desenvolvem de modo frequente o lazer doméstico. Essa característica deve ser 
analisada considerando-se que praticamente a totalidade dos alunos conciliava o último ano da graduação com atividades remuneradas, reduzindo o tempo livre dos mesmos tendo em vista o desenvolvimento das práticas de caráter cultural. Quando não estão trabalhando ou estudando, verificou-se que o tempo passa a ser utilizado de modo frequente para a realização de tarefas cotidianas que envolvem o cuidado com a casa ou o descanso, no caso deste último pela necessidade de reposição da força de trabalho, sobretudo entre os respondentes da FEUSP, UNIBAN-Anhanguera e UNIFESP.

O fato do lazer doméstico envolver menos custos também deve ser levado em consideração, principalmente entre os respondentes que possuem níveis de renda familiar mais baixos, como os estudantes da UNIBAN-Anhanguera e UNIFESP. Os limites financeiros desses alunos se prolongam do acesso limitado à internet (caso específico da UNIBANAnhanguera), aos bairros de moradia desprovidos de equipamentos culturais e afastados das regiões da cidade de São Paulo mais munidas desses recursos (região central e oeste de São Paulo).

Bourdieu (2007, p. 350) observa, porém, que as práticas culturais além de sofrerem as pressões econômicas, produzindo o "gosto de necessidade" nas famílias portadoras de menor poder aquisitivo, ou seja, a "preferência" pelo simples e viável, são também afetadas pela formação cultural dos agentes no ambiente doméstico (habitus primário) e escolar (habitus secundário). Assim, quanto maior o contato dos respondentes com práticas culturais variadas no meio familiar, tanto maior será sua predisposição ao consumo das mesmas. Essa formação prévia e espontânea, ofertada pelas famílias portadoras de um volume relativo de capital cultural, tem sua continuidade por meio da ação escolar, instituição essa que a sociedade espera ser capaz de ampliar e aprofundar os saberes culturais de seu alunado.

Ao justificar a importância de uma investigação voltada para o estudo das práticas culturais de professores, o relatório da $\operatorname{UNESCO}(2004$, p.89) destaca que o trabalho docente envolve a "formação da pessoa no sentido mais amplo, o que inclui a estética e o ético, entre outras dimensões da vida", para além de oferecer aos alunos a oportunidade de terem contato com a produção do conhecimento nas mais diversas áreas do saber. O relatório destaca, portanto, a função da escola como espaço de cultura, meio no qual deve fazer parte do processo educativo o contato com a "música, literatura, teatro, cinema", entre outras manifestações.

Pierre Bourdieu (2013), no texto "A escola conservadora: as desigualdades frente à escola e à cultura", apresenta a instituição escolar como um espaço que legitima as desigualdades sociais ao favorecer os estudantes portadores de uma herança cultural familiar 
elevada, enquanto exclui os alunos originários das camadas sociais mais baixas, pertencentes a famílias que pouco puderam contribuir no domínio dos saberes e modos de comportamento valorizados pela escola. Ao desconsiderar a origem social de seus alunos e a influência desta no processo de aprendizagem, a escola se torna uma instituição promotora e perpetuadora das desigualdades sociais. Uma proposta de superação dessa ação escolar indicada pelo autor seria, inicialmente, reconhecer o modo como a origem social dos alunos afeta sua aprendizagem e criar mecanismos não eliminatórios dos mesmos, mas sim formativos, gerando nos alunos as necessidades culturais que suas famílias não tiveram condições de proporcionar. Sendo a necessidade cultural fruto da educação, cabe à escola a criação de uma atitude cultivada entre seus alunos, cujo domínio do código cultural seria responsável pela produção do interesse.

Tendo por caráter a vastidão de sua ação educacional, caracteriza-se como coerente a reflexão acerca do perfil cultural necessário aos docentes para que possam completar com êxito os objetivos do seu trabalho, considerando-se a ampliação do entusiasmo pela cultura geral e artística de seus alunos. Do mesmo modo que Bourdieu (2013) produziu um alerta para o fato de estudantes dotados de baixo capital cultural primário (origem familiar) sofrerem processos de exclusão na escola, professores ou aspirantes ao trabalho docente, de origem social vinculada às camadas populares, experimentam a mesma privação formativa de origem, produtora de práticas culturais pouco distintivas e, portanto, limitadoras da realização dos propósitos formativos que envolvem seu trabalho.

Setton (1989), ao investigar em sua dissertação de mestrado as práticas culturais de professores que lecionavam no ensino fundamental e médio, identificou que os mesmos desenvolviam poucas atividades voltadas ao consumo cultural. Esse quadro foi justificado pela autora como decorrente da condição de vida dos docentes, marcada por restrições financeiras e posse de pouco tempo livre destinado ao repouso e ao lazer. Entre as atividades praticadas pelos professores investigados a autora constatou a preferência, de modo geral, por aquelas realizadas no ambiente doméstico, como leitura, assistência à TV e audiência ao rádio, havendo um interesse maior pelos best-sellers e revistas de conteúdos superficiais, além da audiência de músicas que representavam "os sucessos do momento" e de "fácil fruição" (p.117;125).

As práticas culturais docentes também foram objeto de investigação por parte da UNESCO (2004), a partir de um levantamento nacional realizado no ano de 2002. Apesar da pesquisa ter ocorrido aproximadamente vinte anos depois da investigação desenvolvida por Setton (1989), seus resultados mostraram-se muito semelhantes. Assim, novamente foi observada a recorrência do lazer doméstico, com destaque para a assistência à TV e fitas de 
vídeo. Por outro lado, a visitação a museus e exposições, bem como idas ao teatro e cinema apresentaram recorrência muito baixa, principalmente entre os docentes que possuíam renda familiar reduzida. Em termos de prática de leitura, os mesmos demonstraram dedicar seu tempo aos materiais de estudo e formação, havendo pouco interesse pela literatura de fruição e jornais. Observou-se, ainda, que os docentes faziam pouco uso de computadores e também raramente acessavam a internet.

Utilizando os dados extraídos do questionário socioeconômico aplicado quando da realização do Exame Nacional de Cursos (ENADE) no ano de 2005, Gatti e Barreto (2009) investigaram as práticas culturais dos estudantes dos cursos de licenciatura (Biologia, Física, Química, Matemática, História, Geografia, Letras e Pedagogia) participantes do exame naquele ano. Entre os resultados, notou-se que o cinema era a prática cultural externa mais mencionada, porém a proporção de visitantes recorrentes não atingiu metade do grupo pesquisado. O teatro foi indicado como espaço pouco frequentado, assim como os concertos musicais. Em termos de prática de leitura notou-se que a preferência dos alunos do curso de Pedagogia abrangia a leitura de livros técnicos ou de autoajuda, ao mesmo tempo que poucos se interessavam pelas obras literárias. A respeito dos recursos consultados como fonte de informação, foi verificada a preferência pela televisão e internet, havendo pouca procura pelo jornalismo impresso. Uma diferença significativa observada entre os alunos e os professores estudados no relatório da UNESCO (2004) diz respeito ao uso das novas tecnologias. Enquanto os professores pouco faziam uso dos recursos da informática, os estudantes comunicaram uso frequente dos computadores e também da internet.

Os dados gerais a respeito das práticas culturais docentes apontadas pelas pesquisas indicam pouco contato dos mesmos com as atividades de lazer externas, bem como a preferência pelo consumo cultural massificado, sendo que este mesmo padrão de aproveitamento cultura se repetiu entre os estudantes dos cursos de licenciatura de acordo com Gatti e Barreto (2009). No caso dos respondentes das quatro universidades (FEUSP, PUC-SP, UNIBAN-Anhanguera e UNIFESP) aqui investigados, foi de fato visível a reiteração do lazer doméstico e da realização de práticas culturais pouco distintivas no âmbito da leitura, da audição musical e assistência à televisão.

As respostas oferecidas pelos alunos investigados deram indícios de que os mesmos reconhecem, mais do que propriamente conhecem, certos objetos de cultura. O fato da revista Veja e dos jornais Folha de S. Paulo e Estado de S. Paulo serem os mais mencionados, assim como a demonstração da preferência generalizada pela MPB, não indicam necessariamente que 
a informação prestada no momento da pesquisa seja realmente efetivada na vida cotidiana dos estudantes. Essa atitude diante do questionário pode representar aquilo que Bourdieu (2007) denominou como "boa vontade cultural", ou seja, na expectativa de oferecer respostas concebidas pelo investigado como adequadas ao contexto da pesquisa, o mesmo se preocupa em apresentar uma imagem de si que não corresponde de fato com sua prática cotidiana. No que se refere à leitura de revistas e jornais, deve mesmo ser observado como relevante a constatação dos alunos pouco se interessarem por essas fontes de notícia. O conteúdo informativo também é pouco acessado na programação televisiva e no uso da internet.

O exame das atividades de lazer menos praticadas permitiu identificar que as mesmas ocorriam de modo muito similar nas quatro instituições, havendo pouca recorrência das visitas ao teatro, aos museus e aos concertos musicais em todas as universidades. Considerando especificamente os respondentes da UNIBAN-Anhanguera, USP e UNIFESP os mesmos também pouco frequentavam as salas de cinemas e parques, além de haver baixa participação nas práticas esportivas e realização de viagens. A PUC-SP distingue-se das demais pelo fato dos alunos investigados terem uma maior frequência no desempenho de atividades que demandam capital econômico mais elevado.

Um primeiro aspecto a ser mencionado é que o cinema, apesar de ser uma prática pouco usual, consistiu na atividade de lazer externa mais comum entre os estudantes aqui investigados. Botelho e Fiore (2005) destacam que o predomínio das atividades domésticas não é um fenômeno especificamente brasileiro, mas se trata de um hábito que vem se consolidando mundialmente como decorrência da evolução do acesso aos equipamentos eletrônicos, que permitem uma diversidade significativa de práticas culturais domiciliares. Earp e Paulani (2014) atribuem à estabilização da economia brasileira, em meados da década de 1990, o crescimento do consumo de bens duráveis e a consequente mudança no padrão das atividades culturais da população:

Podemos, portanto, perceber aí alguns movimentos simultâneos. Primeiro, o deslocamento de uma parcela substantiva do entretenimento do espaço público para o espaço privado, com o deslocamento do consumo de filmes da sala de cinema para a residência, através de TV e DVDs. Segundo, o surgimento de um espaço público de sociabilidade virtual, a internet, em que o contato pessoal é intermediado pelo meio eletrônico, por meio de redes sociais e comunidades virtuais. Terceiro, o uso da internet para difusão de conteúdos variados, inclusive músicas e filmes pirateados, em detrimento das redes de comercialização estabelecidas. Quarto, o deslocamento do uso do tempo livre para essas novas atividades, o que implicou a redução do consumo de livros, CDs e de ingressos em salas de cinema (EARP; PAULANI, 2014, p. 480). 
Desse modo, a redução da frequência ao cinema não está relacionada ao desinteresse por filmes, mas pela possibilidade de assisti-los via novos suportes de entretenimento. De fato, tal perspectiva pôde ser observada nesta investigação, uma vez que os respondentes das quatro instituições indicaram, tal como comentado anteriormente, um forte interesse pela assistência à televisão e por sua programação de entretenimento, com destaque para os filmes e séries.

Estudos a respeito das práticas culturais, porém, indicam que as atividades domiciliares não substituem aquelas desenvolvidas fora do ambiente doméstico, uma vez que o alto índice de práticas externas está associado a elevados padrões de consumo domiciliar. Contrariamente, fracos praticantes domiciliares são geralmente pouco afeitos ou nãopraticantes de atividades culturais externas. No caso destes últimos, sua conduta está frequentemente relacionada a baixos níveis de renda, formação e informação:

Quem se relaciona fora do ambiente doméstico, quem se informa (pela leitura de jornais e revistas) e quem circula pela cidade terá maior tendência a buscar mais informação sob outras formas, tento em práticas culturais domiciliares como fazer novas leituras, ouvir novos discos - quanto em práticas externas como ir ao cinema, ao teatro, a concertos, espetáculos diversos etc. (Botelho e Fiore, 2005, p. 15)

Botelho e Fiore (2005) confirmam para o caso brasileiro, portanto, a adequação da formulação teórica de Bourdieu (2007) que identificou como princípios fundamentais das práticas culturais na sociedade francesa, a origem social (capital cultural e econômico) e o capital escolar dos agentes. Nesse sentido, o nível de formação cultural familiar e o perfil econômico da mesma afetam a constituição do habitus primário dos agentes e, consequentemente, suas práticas. Quanto maior o nível formativo dos pais e mais diversificadas forem as experiências culturais vivenciadas pelos mesmos, mais precoce e espontâneo será o contato de seus filhos com a cultura. $\mathrm{O}$ capital econômico nessa circunstância favorecerá o acesso aos bens culturais objetivados, além de influenciar o percurso formativo escolar. De acordo com Lasne (2013), o capital cultural e econômico das famílias influenciam o padrão da formação escolar a qual seus filhos terão acesso. Quanto mais elevados esses dois capitais, mais condições as famílias terão de controlar a qualidade da oferta pedagógica e a eficácia da continuidade da formação educativa iniciada no ambiente doméstico.

No caso dos respondentes das quatro instituições, foram identificadas variações em relação à origem social dos mesmos, assim as famílias dotadas de menor poder econômico e formação cultural, bem como uma trajetória formativa marcada pela passagem por escolas públicas estão associadas à UNIBAN-Anhanguera. Na UNIFESP, notou-se a posse de um nível de renda superior aos das famílias da UNIBAN-Anhanguera, enquanto o grau formativo dos 
genitores se elevou, havendo um maior número de alunos que contavam com pais formados no ensino médio e superior, apesar da presença significativa daqueles cujo nível máximo de instrução se deu no alcance do ensino fundamental. Por fim, na UNIFESP o número de alunos egressos das escolas públicas é significativamente superior em relação ao volume de alunos oriundos de instituições particulares. Na PUC-SP e FEUSP, por sua vez, encontram-se os alunos portadores de níveis de renda mais elevados e familiares portadores de nível de instrução associados ao nível superior.

Do mesmo modo que o peso relativo dos capitais econômico e cultural detidos pelos respondentes participou na definição de suas estratégias formativas (ser estudante da UNIBANAnhanguera ou da UNIFESP, por exemplo), a influência do mesmo agiu também na delimitação das práticas culturais efetivadas entre os alunos investigados. Assim, não foi por mera coincidência que se deu a identificação de atividades culturais comuns aos estudantes das quatro universidades, manifesto pela recorrência do lazer doméstico, bem como pelo desinteresse partilhado pelas práticas que envolvem as visitas ao teatro e museus, além da audição a concertos musicais. Essas afinidades são indicativas de que os mesmos ocupam posições próximas no interior do espaço social, de acordo com o volume global de capital econômico e cultural - que possuem. Daí, segue-se que "os agentes têm tanto mais em comum quanto mais próximos estejam nessas duas dimensões [capital econômico e cultural], e tanto menos quanto mais distantes estejam nelas.” (Bourdieu, 1996, p.19).

Porém, ao mesmo tempo que foram identificadas práticas culturais partilhadas, deu-se igualmente o reconhecimento de especificidades que particularizam os estudantes associados às diferentes instituições, bem como aos diferentes turnos em que o curso de Pedagogia foi frequentado. Essa variação resulta da estrutura do capital, ou seja, da contribuição relativa de cada um dos capitais (econômico e cultural) na composição do volume do capital global. De acordo com Bourdieu (1996), é a estrutura dos capitais que fundamenta as diferenças nas disposições (habitus) e nas tomadas de posição (práticas): “A cada classe de posições corresponde uma classe de habitus (ou de gostos) produzidos pelos condicionamentos sociais" (p. 19).

Iniciando pelos respondentes da UNIBAN-Anhanguera, é possível identificá-los como os agentes portadores do volume global de capitais mais baixo entre todos os respondentes envolvidos neste estudo, consequentemente, os mesmos apresentam uma significativa homogeneidade entre si no âmbito de suas práticas, sendo estas pouco desenvolvidas e qualificadas. O mesmo não se dá em relação aos respondentes da PUC-SP, FEUSP e UNIFESP. 
Na PUC-SP, foi possível observar que a elevação do capital econômico de certos respondentes interferiu diretamente em algumas de suas práticas. Assim, a indicação de museus estrangeiros; a elevação da frequência das práticas esportivas; a realização de viagens e a visitação a parques mostraram-se mais comuns entre os respondentes portadores de faixas de renda mais elevadas. Por outro lado, a escuta dos gêneros musicais tais como samba, blues e reggae, bem como a leitura de jornais internacionais e revistas especializadas ou portadoras de artigos mais densos, constituíram-se como práticas comuns entre os respondentes que pertenciam a famílias com níveis mais elevados de renda e formação cultural. Por fim, a frequência ao teatro não apresentou associação com os níveis de renda, mas sim com a elevação do nível de instrução familiar.

Considerando-se os respondentes da FEUSP, a observação de suas práticas de lazer externas indicou, tal como observado na PUC-SP, que a frequência a museus (estrangeiros) e parques, a prática esportiva e a realização de viagens, tenderam a possuir maior ocorrência entre os agentes detentores de níveis de renda mais elevados. A prática esportiva, especificamente, além da posse de uma renda mais significativa, também estava associada aos estudantes do período diurno. Em termos de leitura, verificou-se a existência de associação entre a menção de jornais internacionais e revistas não populares, portadoras de conteúdo mais denso, aos formandos que concluíram seus estudos em escolas particulares, enquanto suas famílias de origem são detentoras de elevado nível de instrução e renda. A assistência a filmes não voltados ao grande público também guardou relação com condições socioeconômicas e culturais mais privilegiadas. Convém mencionar que a seleção de músicas entendidas como distintivas foi comum entre os respondentes da FEUSP, de modo geral. Assim, não foi observada a existência de relação entre o gosto musical seleto e níveis de escolaridade e renda mais elevados, dandose o mesmo em relação aos livros e ao teatro. A indicação de best-sellers teve ocorrência nas diferentes faixas de renda, bagagem cultural familiar e formação escolar dos respondentes, do mesmo modo que a indicação de obras seletas. Quanto ao teatro, só existiu associação específica com a renda familiar quando os espetáculos tinham por característica uma grande divulgação midiática.

Assim como foi notado na USP e PUC-SP, certos alunos da UNIFESP demonstraram a posse de um gosto diferenciado. O mesmo se manifestou na preferência musical, na escolha das leituras, indicação de museus e peças teatrais. No caso da música, os dados revelaram que os gêneros distintivos, costumeiramente relacionados aos agentes portadores de um alto nível cultural, não possuíam associação com uma bagagem cultural familiar elevada ou com um perfil 
formativo específico por parte dos respondentes. Notou-se, porém, que nas faixas de renda acima de três salários mínimos per capita, não ocorreram menções ao pagode, sertanejo, rap e ao gospel. Quanto ao perfil dos materiais de leitura, o cruzamento das informações: fontes seletas x grau de instrução familiar x trajetória formativa do aluno na educação básica, indicaram que o estudo no período matutino durante o ensino médio, acompanhado da ausência da necessidade de trabalho nessa fase da formação estão correlacionados com a indicação de revistas, jornais e livros diferenciados. No que se refere aos museus, verificou-se associação na indicação de espaços de visitação internacionais (em duas ocasiões, somente) com a formação familiar universitária e alunos egressos do ensino médio privado diurno. Finalmente, a capacidade de indicar de forma acertada o nome da última apresentação teatral teve relação com mães que concluíram o ensino médio e alunos que cursaram sua formação escolar básica, sobretudo no período diurno, em dedicação exclusiva à escola.

\subsection{ESCOLHA PROFISSIONAL, REPRESENTAÇÕES ACERCA DA DOCÊNCIA E AS PERSPECTIVAS DE ATUAÇÃO NA ÁREA APÓS A CONCLUSÃO DO CURSO}

O tratamento estatístico dos dados coletados nesta pesquisa permitiu a identificação das variáveis que possuem associação significativa com a escolha do curso de Pedagogia como primeira opção de formação profissional. Entre os resultados obtidos, apresentados na Tabela 6.1, destaca-se o fato da FEUSP reunir o maior número de alunos que não tinham a graduação em Pedagogia em seus planos iniciais (38/65). Uma melhor interpretação do resultado obtido na FEUSP exige que se considere o fato dessa faculdade reunir um número significativo de alunos que iniciaram outros cursos de graduação anteriormente ao ingresso na formação em Pedagogia. Diante da questão "O curso que você está seguindo foi sua primeira opção de formação profissional?", parte dos respondentes indicaram “não" como retorno, tendo em vista suas experiências formativas universitárias prévias ${ }^{2}$. Assim, dos 38 alunos enquadrados na categoria "não", dezenove registraram essa resposta pelo fato de já serem formados ou por terem iniciado algum outro curso superior precedentemente.

É importante mencionar que os respondentes da PUC-SP e UNIFESP, não apresentaram a mesma orientação interpretativa dos alunos da FEUSP. Assim, mesmo sendo formados em outras áreas eles indicaram o curso de Pedagogia como sua primeira opção,

\footnotetext{
${ }^{2}$ Infelizmente o modo como a questão foi formulada permitiu a dubiedade de sua interpretação por parte dos estudantes investigados.
} 
quando era o caso, ou como segunda opção, quando realmente o interesse formativo seguia por outra alternativa.

Isto posto, uma análise abrangente dos dados sugere que a UNIBAN-Anhanguera apresentou o maior número de alunos que objetivavam frequentar esse curso desde o princípio (16/20), enquanto os resultados da PUC-SP também oferecem indícios de uma forte adesão inicial dos respondentes ao curso. Por fim, é relevante na UNIFESP o índice quase equilibrado entre os que tinham ou não a Pedagogia em suas disposições formativas originais, residindo nessa instituição o maior índice de respondentes que alteraram seus planos iniciais.

Tabela 6.1 - Associação entre opção pelo curso de Pedagogia x instituição.

\begin{tabular}{lccc}
\hline & Não & Sim & Total \\
\hline FEUSP & 38 & 27 & 65 \\
PUC-SP & 9 & 16 & 25 \\
UNIBAN & 4 & 16 & 20 \\
UNIFESP & 25 & 27 & 52 \\
\hline
\end{tabular}

O resultado obtido na UNIFESP pode ser interpretado como efeito do processo seletivo adotado pela instituição: o SISU. Nesse sistema de seleção o candidato indica, por ordem de preferência, duas opções de cursos dentre as vagas ofertadas pelas universidades federais. Ao longo do período de inscrições, as notas de corte parciais são publicadas diariamente, tendo os candidatos a oportunidade de mudar sua opção por outra que lhe ofereça mais chances de classificação.

A análise estatística também identificou algumas características que particularizam os respondentes que tinham o curso de Pedagogia como primeira opção formativa (Tabela 6.2). Tais características possuem relação: a) turno em que o ensino médio foi cursado; b) ocupação profissional materna; c) renda per capita mensal familiar e d) hábito de leitura. Assim, tenderam a escolher o curso de Pedagogia como primeira opção os respondentes que cursaram o ensino médio durante o período noturno e que se dividiam entre a dedicação aos estudos e ao trabalho. Ao mesmo tempo, foi observado que estudantes cujas mães pertenciam à categoria de trabalhadoras manuais tinham mais fortemente o curso de Pedagogia como sua primeira opção (Tabela 6.3), enquanto esse interesse nas demais categorias ocupacionais se apresenta diminuído. A Pedagogia também tendeu a ser primeira opção entre os respondentes cuja renda familiar per capita alcançava até um salário mínimo (Tabela 6.4). Por fim, a última correlação, apresentada na Tabela 6.5, identificou que leitores assíduos apresentaram uma leve tendência 
a não selecionar Pedagogia como primeira opção. Contrariamente, respondentes com baixa frequência de leitura apresentaram maior tendência a selecionar o curso como sua primeira opção.

Tabela 6.2 - Associação entre turno de estudos no ensino médio e opção pelo curso de Pedagogia

\begin{tabular}{lcc}
\hline 1 opção & Matutino & Noturno \\
\hline Não & 65 & 11 \\
Sim & 53 & 33 \\
\hline
\end{tabular}

Tabela 6.3 - Associação entre ocupação materna e opção pelo curso de Pedagogia

\begin{tabular}{lccc}
\hline 1 opção & $\begin{array}{c}\text { Profissional liberal ou } \\
\text { atividade profissional } \\
\text { com exigência } \\
\text { formativa elevada. }\end{array}$ & $\begin{array}{c}\text { Serviços } \\
\text { administrativos, } \\
\text { comércio, serviços } \\
\text { técnicos e demais } \\
\text { ocupações que } \\
\text { exigem formação } \\
\text { escolar mediana. }\end{array}$ & $\begin{array}{c}\text { Trabalho manual, } \\
\text { produção de bens e } \\
\text { serviços industriais e } \\
\text { atividades } \\
\text { profissionais que } \\
\text { exigem baixa } \\
\text { exigência formativa. }\end{array}$ \\
\hline Não & 26 & 18 & 27 \\
Sim & 24 & 12 & 48 \\
\hline
\end{tabular}

Tabela 6.4 - Associação entre opção pelo curso de Pedagogia x renda per capita familiar

\begin{tabular}{lcccc}
\hline 1 opção & Até $\mathbf{~ s m}$ & 1 até $\mathbf{~} \mathbf{~ s m}$ & 2 até $\mathbf{4 ~} \mathbf{~ s m}$ & 4 ou mais \\
\hline Não & 11 & 32 & 23 & 10 \\
Sim & 30 & 26 & 18 & 12 \\
\hline
\end{tabular}

Tabela 6.5 - Associação entre opção pelo curso de Pedagogia e frequência da leitura de livros

\begin{tabular}{lcc}
\hline 1 opção & Muito & Pouco \\
\hline Não & 60 & 10 \\
Sim & 55 & 26 \\
\hline
\end{tabular}

Gouveia (1970), em seu estudo sobre a escolha vocacional para o magistério, obteve resultados próximos aos aqui apresentados. De acordo com sua pesquisa, o interesse pelo magistério era menos frequente entre as jovens cujos pais possuíam nível de formação mais elevado, ao mesmo tempo que a profissão atraía estudantes com menor qualificação acadêmica. Nessa mesma perspectiva investigativa, Louzano et. al. (2010) identificaram que o Brasil atrai indivíduos com baixo rendimento acadêmico e perfil socioeconômico modesto para os cursos de formação de professores. Utilizando os dados do ENEM de 2005, os autores constataram que "apenas $10 \%$ dos interessados na carreira docente estão entre os melhores alunos do ensino médio do país. Por outro lado, cerca de um terço dos estudantes interessados na carreira docente estão entre os piores em sua coorte.” Já com os dados do Exame Nacional de Desempenho dos Estudantes (Enade) de 2005, Louzano et. al. (2010) observaram que os níveis de escolaridade materna e renda familiar são reduzidos em meio ao alunado do curso de Pedagogia. 
Considerando as justificativas dos respondentes acerca da substituição do primeiro curso escolhido para a graduação em Pedagogia, identificou-se que as restrições objetivas agiram como fatores determinantes na mudança das perspectivas de formação profissional. $\mathrm{O}$ levantamento dos cursos originalmente desejados pelos alunos permitiu identificar que alguns deles possuíam uma relativa proximidade com a graduação em Pedagogia, já que os mesmos partilhavam o pertencimento ao campo educacional (Letras, História, Biologia, Licenciatura em Artes Visuais), porém um número significativo de carreiras não possuíam nenhum tipo de proximidade com a área (Artes Cênicas, Direito, Enfermagem, Gastronomia, Jornalismo, Medicina e Psicologia). Assim, nestes últimos casos, o ingresso desses estudantes na graduação em Pedagogia ocorreu a partir de um distanciamento significativo entre as aspirações iniciais e o curso de fato frequentado. Tais desvios vivenciados entre a formação desejada e a alcançada estavam relacionados às limitações financeiras e à formação cultural insuficiente para a aprovação no processo seletivo. Convém observar que, em alguns casos, a insuficiência de recursos econômicos atuou de modo conjunto aos limites formativos. Assim, a impossibilidade de ser aprovado em uma universidade pública para o curso desejado, acompanhado da inviabilidade do pagamento das mensalidades do curso em uma instituição privada, levou muitos alunos a realizarem uma adequação dos seus planos ao seu universo de possíveis, decorrente de um conhecimento prático incorporado (habitus) que promove o ajuste da conduta dos agentes ao que lhes é acessível, considerando-se sua condição social de origem.

Discutir a opção pela graduação em Pedagogia exige que se considere que a escolha profissional de um agente não é livre das condições sociais, econômicas e culturais que agem sobre ele. Assim, ao supostamente escolher sua profissão, o indivíduo atua a partir das marcas de sua posição social de origem, as quais foram incorporadas e constituem sua própria natureza, guiando seus pensamentos e modos de ação. O agente social, portanto, realiza sua escolha profissional de acordo com seu habitus, agindo adequadamente considerando-se sua localização na estrutura social, uma vez que suas condutas manifestam os comportamentos característicos do seu meio de origem. Fruto dessa adequação, a escolha profissional é ajustada ao objetivamente possível, ou seja, aos limites da realidade social próprios da condição de vida daqueles que elegem a profissão a ser seguida.

Entre os respondentes aqui investigados, ainda no âmbito das limitações financeiras, cursos integrais que impedem a conciliação entre trabalho e estudo, e aqueles entendidos pelos estudantes como portadores de menor potencial empregatício também foram deixados de lado. A escolha circunscrita da profissão docente aqui identificada por parte de alguns estudantes 
também foi observada por Bianchini (2005, p. 106) entre as professoras de educação infantil e ensino fundamental que frequentavam o Curso Normal Superior, por ela investigadas. Entre seus resultados a autora constatou que para diversas professoras "a opção pela formação foi a única possível (...) imposta pelas condições econômicas de suas famílias”. Do mesmo modo, Marin (2003, p. 61) identificou nas práticas discursivas de professoras das séries iniciais do ensino fundamental, que a decisão de algumas delas pelo magistério sobreveio da "submissão ou subordinação às condições objetivas em que viviam”, resultando no ingresso em um curso de formação de professores sem que a docência fosse conscientemente compreendida em seu sentido social.

A esse respeito, o estudo das motivações que conduziram os respondentes das quatro universidades ao curso de Pedagogia permitiu a classificação de três grandes justificativas partilhadas pelos investigados: a) identificação pessoal com a profissão; b) interesses profissionais e c) engajamento social. Na primeira categoria encontram-se os alunos que destacaram em suas respostas o reconhecimento em si de uma simpatia pelas atribuições do pedagogo, pesando na construção do argumento a ideia de que esta escolha atende a características e interesses pessoais do estudante, tais como: a expectativa de ser professor, o gosto por ensinar, a facilidade em lidar com pessoas e a disposição em trabalhar com crianças.

A fundamentação do interesse pela profissão tendo em vista o trabalho com crianças é comumente identificada em pesquisas que investigam as motivações da escolha pelo curso de Pedagogia (MARIN, 2003; OCDE, 2006; GUIMARÃES, 2010; LEME, 2012; SILVA, 2013). A associação estabelecida por aqueles que pretendem cursar essa graduação com sua identificação pessoal pelo público infantil, tem relação com o fato do magistério nas séries iniciais ser, ainda atualmente, perpassado pelas representações de gênero. No caso deste estudo, a significativa procura do curso por representantes do sexo feminino (tal como ilustra o Gráfico 6.1) evidencia a permanência de imagens coletivas que identificam o exercício da docência à habilidade em lidar com crianças, sendo esta uma atribuição essencialmente vinculada a traços de personalidade femininos, que terminaram por reduzir o trabalho do professor primário a um prolongamento da função materna (PEREIRA, 1969; FERNANDES ENGUITA, 1991). 


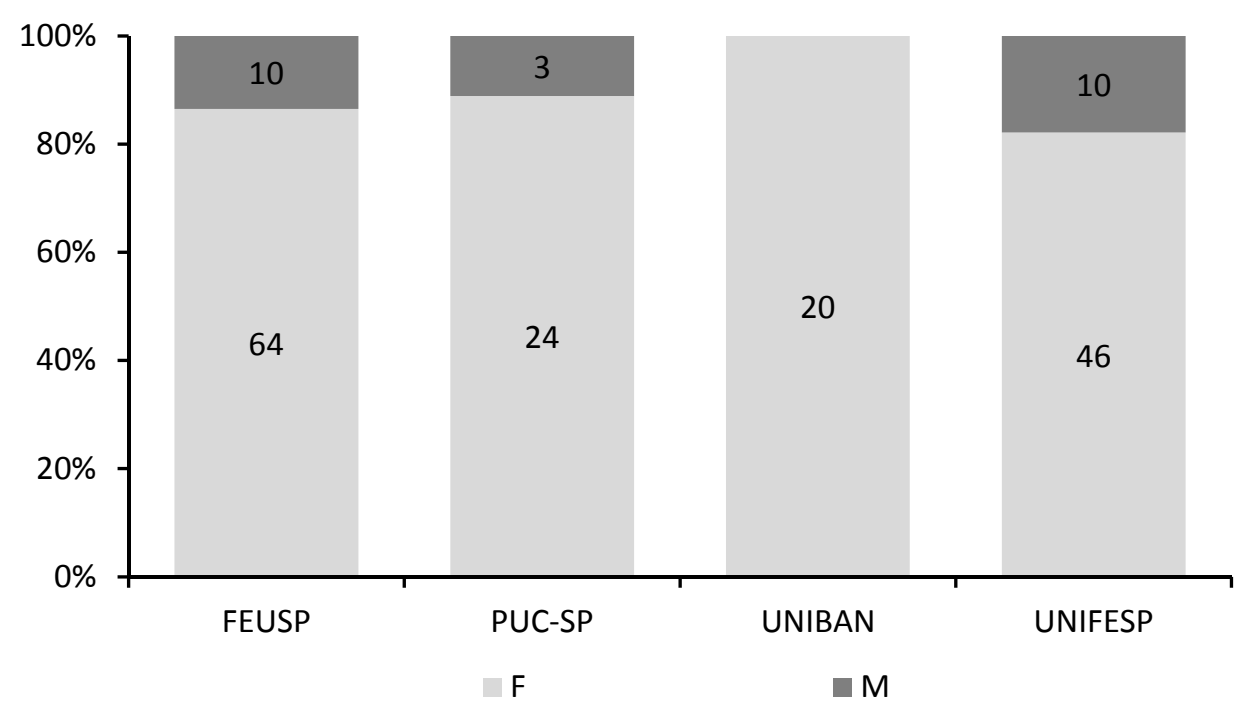

\section{Gráfico 6.1 - Distribuição dos alunos segundo sexo por instituição.}

Fonte: Chiann, Mitsuuchi e Sato (2014)

Pereira (1969) destaca que o ingresso das mulheres na população economicamente ativa se deu principalmente por meio do exercício do magistério, por ser esta uma atividade que permitia a conciliação dos papeis domésticos e profissionais, favorecendo assim a manutenção do equilíbrio de uma sociedade paternalista, estruturada por meio de relações assimétricas entre os sexos. Nesse contexto, Louro (1997, p. 78) acentua a existência de argumentos que identificavam na natureza feminina uma vocação para o trato de crianças, sendo as mulheres "as primeiras e naturais educadoras. Se a maternidade é, de fato, o seu destino primordial, o magistério passa a ser representado também como uma forma extensiva da maternidade. (...) A docência, assim, não subverteria a função feminina fundamental, ao contrário, poderia ampliála ou sublimá-la." Diante do discurso construído a respeito da adequação das mulheres ao desempenho da atividade de ensinar crianças, já na década de 1960 o magistério primário consistia em atividade profissional quase absolutamente feminina, uma vez que 93,4\% dos docentes desse nível de ensino eram mulheres (PEREIRA, 1969).

Dados recentes voltados à caracterização do professor brasileiro e elaborados a partir dos resultados do Censo Escolar da Educação Básica de 2007, indicam a manutenção do perfil predominantemente feminino nos primeiros anos de escolarização: "Nas creches, na pré-escola e nos anos iniciais do ensino fundamental, o universo docente é predominantemente feminino (98\%, 96\% e 91\%, respectivamente)" (INEP, 2009, p. 22). Catani et. al. (1997, p. 39) problematizam essa composição do magistério primário e a situam no interior de um processo 
histórico e cultural que constitui por meio da disseminação de valores, crenças, hábitos e modos de pensar, as marcas responsáveis pela identificação de homens e mulheres. De acordo com as autoras "Família e escola são os espaços onde se educa e se constrói a mulher e, mais adiante, a professora.", uma vez que essas instituições e demais manifestações culturais, sinalizam e prescrevem as formas de comportamento adequadas e esperadas para os representantes de cada um dos sexos. Assim, a predominância das mulheres entre os respondentes investigados, bem como a presença do ideário de que a escolha profissional se deu a partir do interesse pelo trabalho com crianças, ilustra o fato de que certas representações sobre o curso de Pedagogia como espaço de formação profissional feminino, devido ao tipo de trabalho para o qual os alunos são preparados, ainda circulam na sociedade atual e fazem parte do ideário coletivo a respeito da profissão.

Charles e Clément (1997) em estudo sobre a origem dos agentes sociais que decidem trabalhar como professores na França identificaram, tal como ocorre no Brasil, um forte processo histórico de feminização do ensino primário, que se estende nas séries posteriores para o ensino de línguas. Numa tentativa de explicação desse panorama, os autores investigaram a formação das mães das estudantes e identificaram que o exercício do magistério representava para as alunas o desempenho de uma ocupação que supera as atividades profissionais desenvolvidas por suas próprias mães, geralmente associadas ao trabalho doméstico ou identificadas a trabalhos desempenhados pelas frações inferiores das classes médias e das classes populares (em menor número). Assim, diante da condição de trabalho experimentada pelas mães dessas estudantes, o exercício do magistério constitui o alcance de uma promoção social relativa. Por fim, os autores destacam também que em termos salariais e diante da segurança na obtenção de trabalho em um período de desemprego crônico, a atividade docente termina por se apresentar para essas estudantes como uma atividade profissional bastante atrativa.

A alta empregabilidade em torno da profissão docente e a estabilidade na manutenção do trabalho também foram apontadas por Rayou e Zanten (2004) como atrativos para o ingresso na profissão docente na França. De acordo com os autores, a entrada na profissão significa para muitos jovens o benefício da conquista de um emprego estável no âmbito de um mercado de trabalho que se apresenta pouco favorável aos mesmos. Ainda a respeito das condições de trabalho na França, Poulogiannopoulou (2012), em sua tese de doutorado, identificou por meio de entrevistas que muitos estudantes dirigem-se aos cursos de formação para o magistério como uma estratégia de fuga dos problemas de ordem socioeconômicos ligados ao desemprego. Do 
mesmo modo, Louzano et. al. (2010, p. 548) apontam estudos internacionais que ressaltam as altas taxas de obtenção de trabalho na área educacional como um dos seus principais atrativos: “Os professores raramente ficam desempregados por longos períodos de tempo".

No âmbito da pesquisa em questão, parte significativa dos respondentes das quatro universidades indicou seus interesses profissionais como uma das fortes motivações que os conduziram ao curso de Pedagogia. Esse grupo de justificativas foi amplamente empregado por respondentes que já exerciam o magistério antes de ingressarem nessa segunda graduação ou que possuíam títulos de bacharéis. Entre os que já eram professores, o ingresso no curso de Pedagogia deu-se pelo fato dos mesmos estarem interessados na vivência de uma formação continuada, tendo em vista o aperfeiçoamento de sua prática profissional. Outros alegaram o interesse de utilizarem o título de pedagogo para ocuparem novas funções e cargos no âmbito da estrutura administrativa escolar, como coordenadores pedagógicos ou diretores escolares.

No caso dos bacharéis, o curso de Pedagogia consistiu em uma formação atrativa para os que enfrentavam dificuldades na obtenção de trabalho a partir dos diplomas obtidos anteriormente. Essa segunda graduação representava, portanto, a solução que buscavam para o enfrentamento das dificuldades vivenciadas tendo em vista sua inserção no mercado de trabalho. Por outro lado, houve casos de expectativa pela mudança de atividade profissional, uma vez que os mesmos estavam insatisfeitos com as ocupações que vinham desempenhando. Neste último caso, apareceram em suas aspirações a vontade de trabalhar com algo que fosse realmente satisfatório e motivador e que ao mesmo tempo tivesse relação com suas crenças e necessidades pessoais ("fazer a diferença"; "fazer algo que me deixasse feliz"; "encontrar realização pessoal").

Deve-se destacar, porém, que muitos respondentes justificaram a mudança do curso inicialmente desejado para a Pedagogia, justamente por este último oferecer maiores chances de inserção no mercado de trabalho e a oportunidade de conquistar um cargo público via concurso. Assim, cursos como Artes Cênicas, Jornalismo e Psicologia foram deixados de lado pelo receio por parte dos interessados de surgirem poucas chances de trabalho após a conclusão dos mesmos. Houve, ainda, alunos que trocaram cursos de licenciatura (Letras, Matemática) pela Pedagogia uma vez que com essa formação os mesmos poderiam, além de dar aulas, também atuar na área de administração escolar. Enge (2004) havia observado essa conduta entre os egressos de cursos de licenciatura da USP, cuja escolha profissional para alguns envolveu menos o interesse de profissionalização em uma determinada área, do que a preocupação em concluir um curso que oferecesse maiores níveis de empregabilidade. 
A terceira e última categoria mais recorrente para justificar o ingresso no curso de Pedagogia teve relação com o engajamento social dos respondentes, sendo esta motivação comum apenas entre os alunos da FEUSP, PUC-SP e UNIFESP. Rayou e Zanten (2004) identificaram entre professores iniciantes o interesse pelo magistério justamente pela possibilidade de trabalharem pelo próximo e pelos mais necessitados. De acordo com os autores, esse comprometimento se dá a partir da compreensão da importância do serviço público e de valores religiosos associados ao altruísmo. Pereira (1969) verificou em seu estudo sobre o magistério primário, que professores das escolas normais na década de 1960 partilhavam de uma representação comum a respeito do docente "ideal". Este era entendido como alguém cuja ação educacional deveria ser orientada pelos princípios coletivistas, ou seja, voltados para os interesses da sociedade e do bem comum. Assim, enquanto a instituição escolar era compreendida como um espaço voltado ao atendimento dos interesses comuns, seus professores deveriam justamente partilhar dessa mesma compreensão, a fim de garantir a efetivação dos objetivos escolares. Louro (1997) destaca que essa percepção acerca do professor ideal possui marcas da dimensão vocacional do trabalho docente, em sua acepção religiosa. Trata-se do resgate do caráter sacerdotal da docência, marcado por valores como: entrega, doação, dedicação, generosidade e altruísmo, os quais ainda se fazem presentes no imaginário daqueles que ingressam nesta profissão.

A permanência dessas representações foi detectada também por Leme (2012), que identificou o engajamento social entre os ingressantes do curso de Pedagogia da USP como uma das razões mais influentes para a escolha da profissão. Do mesmo modo, Louzano et. al. (2010) mencionam que pesquisas internacionais indicam o altruísmo como um dos principais fatores para o encaminhamento de alguns ao trabalho docente. Semelhantemente, os respondentes das quatro universidades aqui investigadas comunicaram em suas respostas, acerca das justificativas para a escolha do curso de Pedagogia, elementos como: o interesse em participar do processo de transformação social; a compreensão da educação como instrumento de intercessão pelo próximo; a vontade de ajudar e cooperar com os demais; a percepção da formação do próximo como uma missão pessoal. Por vezes, os próprios formandos tiveram uma história de vida marcada por adversidades e vislumbravam, por meio da docência, ajudar crianças que enfrentam as mesmas dificuldades que um dia eles próprios viveram. A identificação da história de vida do professor com a de seus alunos e o desejo de auxiliá-los também foi verificada por Bianchini (2011) entre professoras que possuem origem social 
vinculada às camadas populares. Nestes casos, os docentes atribuem à educação a melhora de sua condição de vida e desejam, por meio do seu trabalho, fazer o mesmo por seus alunos.

O discurso engajado dos respondentes também assumiu uma perspectiva política. Assim, muitos defenderam a ideia de atuar como professores tendo em vista a promoção de uma formação cultural qualificada e o preparo de sujeitos ativos socialmente, por meio da posse de uma visão crítica acerca da sociedade. Esse mesmo interesse foi verificado por Valle (2006) em seu estudo acerca dos motivos promotores da decisão pela carreira docente. De acordo com a autora, os agentes sociais que partilham desse ponto de vista identificam a imagem docente a de um ator social, ou seja, alguém dotado da capacidade de promover mudanças a partir da crença no mito do progresso coletivo.

Ao longo do desenvolvimento da pesquisa, observou-se a existência de uma proximidade significativa entre as justificativas da escolha do curso e o modo como os respondentes representam a docência, principalmente no que se refere aos aspectos sociais. Assim, do mesmo modo que uma parcela dos alunos da FEUSP, PUC-SP e UNIFESP optou pelo curso de Pedagogia pela valorização da função social imbuída na profissão, houve uma tendência por parte desses formandos em definirem a figura docente como a de um agente necessariamente dotado de uma forte consciência social. Tal consciência repercutiria nos objetivos do trabalho a ser desempenhado, bem como nos modos de ação desse professor.

No que se refere aos objetivos do trabalho, os respondentes destacaram a educação voltada para a formação de alunos pensantes, dotados de senso crítico e, consequentemente, capazes de compreender e interferir na realidade social. Quanto aos modos de ação, o professor nutrido pelo sentido social do seu ofício conduziria sua forma de agir a partir de princípios morais. Nesse sentido, os alunos apresentaram o professor como alguém cujas atitudes devem ser orientadas pelo comprometimento, engajamento, responsabilidade e dedicação, ou seja, pelo senso do dever à frente dos alunos e da sociedade. Deve ser destacado, porém, que a representação docente formulada a partir de sua conduta foi mencionada de forma muito discreta entre os alunos da FEUSP, PUC-SP e UNIFESP.

Com frequência ainda mais baixa, algumas respostas apresentaram a imagem do professor já dissociada do sentido axiológico de sua função e tendendo à descrição de um caráter marcadamente missionário, sendo essa perspectiva apresentada de forma moderada entre os alunos da PUC-SP, UNIBAN-Anhanguera e UNIFESP. A caracterização docente orientada pelos princípios vocacionais o representa como alguém que se esforça e se sacrifica pelo outro, tal como ilustra a resposta dada por um formando da UNIFESP: Ser professor é "Fazer de sua 
profissão um ideal de vida, não importando quanto custe da sua própria vida para alcançar seus objetivos.” Entre os respondentes da UNIBAN-Anhanguera a representação altruísta do professor foi apresentada por meio de um discurso antitético, elaborado sobretudo pelos já professores, no qual as dificuldades da profissão são sublimadas pelo carisma docente: “(...) ter amor ao próximo, acreditar no futuro, não desistir apesar das dificuldades encontradas, seja pela escola, dos alunos, do salário (...)[sic]”; “(...) por mais que seu trabalho não seja valorizado, você faz isso por que gosta, porque tem o dom de ensinar.”

Finalmente, a representação mais comum entre os respondentes das quatro universidades definiu a figura do professor a partir de sua função pedagógica. Desse modo, nas descrições dos formandos ser professor envolvia, sobretudo, responsabilizar-se pela promoção do ensino e da aprendizagem. A ação de ensinar, porém, foi caracterizada de modo significativamente desvinculado dos aspectos que a classificariam como tradicional, ou seja, centrada na figura de um professor transmissor dos conteúdos. Assim, emergiu de modo expressivo nas respostas a perspectiva do professor mediador, acompanhado pela imagem do aluno cujo aprendizado se efetiva de modo autônomo. A dimensão da aprendizagem, por sua vez, não envolveu somente os alunos, mas também o docente. Este foi apresentado como alguém que necessariamente deve ser dotado de interesse por aprender constantemente, inclusive com seus alunos. A relação do professor com seus estudantes foi descrita a partir de uma convivência dialógica, sendo ainda desejável que o primeiro adote uma atitude compreensiva, respeitosa e colaborativa. A postura do professor também foi identificada à de um educador, o qual deve ter por interesse promover, além da formação cultural, a dimensão moral e ética dos estudantes.

A forte recorrência da associação da imagem do professor como aquele que ensina e se preocupa com a aprendizagem de seus alunos, bem como a descrição das estratégias formativas a serem implementadas, justificam o reconhecimento partilhado pelos respondentes das quatro universidades em torno das disciplinas de Metodologia do Ensino e Didática, como as que mais contribuíram com sua profissionalização no âmbito da Pedagogia. Assim, de modo geral, os respondentes demonstraram valorizar como conhecimento fundamental para a realização do seu trabalho, os saberes que se relacionam com as situações de ensino e que lhes oferecem um conteúdo pedagógico de caráter prescritivo a respeito das estratégias e práticas docentes. Como verificado na Tabela 6.6, na PUC-SP e UNIBAN-Anhanguera destacaram-se também as disciplinas relacionadas com os estudos na área de Psicologia da Educação, enquanto na UNIFESP os estudantes demonstraram valorizar, quase na mesma proporção das 
disciplinas funcionais, as de conteúdo teórico, voltadas à formação intelectual (História, Sociologia e Filosofia da Educação). Os alunos da UNIFESP, portanto, concebem a formação do professor a partir de uma perspectiva que se afasta de um caráter excessivamente pragmático, valorizando na formação do profissional docente também as disciplinas voltadas ao pensamento político e reflexivo.

Tabela 6.6 - Distribuição dos respondentes de acordo com o grupo de disciplinas que mais contribuiu com sua formação em Pedagogia.

\begin{tabular}{ccccc}
\hline & FEUSP & PUC-SP & UNIBAN & UNIFESP \\
\hline Metodologias de ensino e Didática & 39 & 13 & 11 & 25 \\
Psicologia da Educação & 14 & 11 & 7 & 15 \\
História, Sociologia e Filosofia da Educação & 18 & 4 & 2 & 23 \\
Administração escolar, Currículo e Políticas Públicas & 13 & 7 & 2 & 13 \\
Educação Especial & 8 & 3 & 1 & 4 \\
\hline
\end{tabular}

A associação da imagem docente à do profissional que ensina e lida com conhecimentos, ao mesmo tempo que os respondentes reconheceram a importância das disciplinas que os preparam para a situação de ensino, ofereceram informações a respeito do modo como os formandos aqui investigados concebem a profissão docente. Assim, apesar da identificação de estudantes que abandonaram outros interesses formativos e migraram para o curso de Pedagogia como uma segunda opção de formação profissional, nota-se a presença generalizada de uma clara compreensão acerca da função social do trabalho docente, centrada no ato de ensinar conteúdos e promover a aprendizagem de seus alunos.

Em termos de planos profissionais o levantamento de dados indicou que em todas as universidades havia uma significativa expectativa dos respondentes em exercer o magistério. Entre os alunos da UNIBAN-Anhanguera e UNIFESP, foi evidente a propensão dos mesmos pela docência no âmbito das escolas públicas. Os formandos investigados da FEUSP e PUCSP, apesar do interesse em atuar no setor público, não se mostraram tão exclusivamente voltados para o mesmo, havendo maior abertura entre eles para o trabalho nas instituições particulares de ensino, tal como demonstra a Tabela 6.7:

Tabela 6.7 - Distribuição dos respondentes de acordo com o interesse pela docência em instituições públicas ou privadas de ensino.

\begin{tabular}{lcccc}
\hline & FEUSP & PUC-SP & UNIBAN & UNIFESP \\
\hline Docência em escola pública & 20 & 6 & 15 & 30 \\
Docência em escola particular & 7 & 9 & 2 & 5 \\
Docência público/particular & 15 & 0 & 1 & 2 \\
\hline
\end{tabular}


O interesse pelo trabalho no âmbito das redes públicas de ensino, manifesto sobretudo pelos respondentes da UNIFESP e UNIBAN-Anhanguera, pode ser interpretado como uma decorrência da condição econômica dos mesmos, já que estão vinculados a essas instituições os alunos portadores das menores faixa de renda per capita familiar. São estudantes cujas estratégias de reprodução concebem o trabalho no setor privado como uma opção de encaminhamento profissional menos atrativa, diante da estabilidade empregatícia e da segurança financeira que o setor público representa. Contrariamente, os respondentes da PUCSP e FEUSP, possuem uma condição econômica menos restritiva, o que termina por libertá-los do senso de necessidade presente nos demais. Ao mesmo tempo, são estudantes que contavam com a posse futura de um diploma portador de reconhecido valor simbólico, capaz de favorecer a inserção dos mesmos em instituições particulares de ensino mais prestigiosas. Convém recordar que parte dos respondentes da PUC-SP e FEUSP realizavam seus estágios em escolas particulares elitizadas da cidade de São Paulo, sendo que esses mesmos estudantes provavelmente vão privilegiar as instituições particulares de ensino como local de trabalho após o encerramento do curso.

Deve ser destacado que a recusa da atuação em sala de aula também ocorreu em maior proporção entre os respondentes da UNIFESP (13/51), PUC-SP (9/25) e FEUSP (11/55), porém, nestes casos os estudantes substituíram a docência pela pretensão de trabalhar no âmbito da administração escolar (sobretudo entre os respondentes que já eram professores e desejavam iniciar uma carreira na educação) ou em contextos diversificados (museus, organizações não governamentais, hospitais e empresas). Assim, entre os formandos investigados, nota-se a existência de uma forte perspectiva de continuidade na profissão, dado que se aproxima da conclusão apresentada por Gouveia (1970), ao identificar que as incertezas a respeito dos planos vocacionais das alunas do primeiro e terceiro anos do magistério tenderam a diminuir ao longo do desenvolvimento do curso.

A prática do estágio, de acordo com os registros, auxiliou os respondentes no processo de definição dos seus interesses profissionais, sendo a mesma retratada positivamente por uma parte significativa dos investigados, uma vez que lhes ofereceu a certeza da escolha profissional e reforçou o desejo de permanência na área da educação. Mesmo entre os alunos que relataram certo desapontamento com sua vivência de estágio, o discurso de alguns manteve características otimistas, já que os mesmos tenderam a usar sua experiência como uma oportunidade de 
identificar novos espaços de atuação, com os quais tivessem maior afinidade, tal como ilustram os relatos a seguir ${ }^{3}$ :

"Na verdade apenas me deu mais certeza de que queria continuar nessa área." (UNIBAN-Anhanguera)

"Sim. Entrei no curso pensando em seguir carreira acadêmica (pesquisa e docência no ensino superior), durante os estágios me apaixonei pelo trabalho com as crianças e pretendo trabalhar na pré-escola ou nas séries iniciais do Ensino Fundamental.” (FEUSP)

“Sim, pois me mostrou caminhos na profissão que não seja a docência.” (UNIFESP)

"Sim, pois quando atuei no administrativo me identifiquei mais do que em sala de aula." (PUC-SP).

Por outro lado, algumas respostas foram redigidas num tom bastante desencantado e desesperançoso, principalmente em relação ao modo de funcionamento das instituições públicas de ensino. Nestes casos, ficou claro que a decisão por novos campos de atuação e o desejo de não ingressar na sala de aula tiveram no estágio seu ponto de partida:

"Sim, me retirou qualquer ilusão que eu ainda tinha sobre a escola pública." (UNIFESP)

"Completamente, hoje tenho certeza de que não serei funcionária pública estadual, tampouco municipal devido as péssimas condições de trabalho.” (FEUSP)

"Sim, me fez ter certeza de que o sistema escolar atual não funciona e que não quero atuar em escolas.” (PUC-SP)

Deve ser destacado, porém, que nem todas as experiências de estágio nas escolas públicas foram ruins, do mesmo modo que nem todos os estágios realizados em escolas particulares, inclusive nas mais legitimadas, foram necessariamente vivenciados como algo positivo. Os relatos apresentados a seguir, ilustram essa constatação:

“Sim. Já tinha a ideia de que preferia trabalhar com escolas públicas e lecionando. O estágio obrigatório (feito majoritariamente em escolas municipais) reafirmou isto, além de me fazer perceber que prefiro o EF I à EI. Além disso, minha passagem por escola particular me fez perceber que, apesar de gostar muito de lecionar, não gosto do trabalho extremamente hierárquico que se realiza nessas instituições. Gosto da possibilidade de parceria com a Coordenação e Direção.” (FEUSP)

"Na escola eu pude vivenciar muitas coisas que me levaram a duas grandes escolhas que fiz para a minha carreira: não trabalhar em escola particular e não trabalhar

\footnotetext{
${ }^{3}$ Tais constatações resultaram da análise das respostas elaboradas pelos estudantes diante da questão: “O estágio alterou suas expectativas sobre seu futuro profissional? Por quê?"
} 
com o Ensino Fundamental I e nem Educação Infantil. Descobri lá que não são para esses alunos que eu gostaria de dar aula.” (FEUSP)

Por fim, vale informar que não houve associação entre o desejo de não ser professor e o fato do curso ter sido escolhido como primeira ou segunda opção formativa. Porém, verificouse que a recusa da docência foi mais evidente entre os alunos mais velhos e que já estavam consolidados no desempenho de uma ocupação anterior, seja no meio escolar (inspetor escolar; auxiliar administrativo em escola) ou em demais atividades: servidores públicos; professor de idiomas; professor de música e ocupações especializadas (técnico em transportes; revisor; analista de sistemas). Entre esses, os destinos profissionais selecionados foram a) atuar na área da administração escolar (inspetor escolar; auxiliar administrativo em escola; professor de idiomas; professor de música) e b) atuar na área da educação em contextos diversificados (musicista; servidores públicos; professor de idiomas; técnico em transportes). Possivelmente para agentes portadores desse perfil, o desafio de ingressar na sala de aula e lidar com suas dificuldades se apresentou como algo que requeria um esforço maior do que eles estavam dispostos a oferecer.

\subsection{A PEDAGOGIA COMO FORMAÇÃO COMPLEMENTAR: O SENTIDO DA PROCURA DO CURSO ENTRE OS DOCENTES EM ATUAÇÃO}

O levantamento do número de respondentes que se identificaram como professores ao serem questionados acerca do desempenho de suas atividades ocupacionais permitiu constatar que em todas as universidades, alunas do curso de Pedagogia - sem qualquer outra formação prévia - já estavam atuando informalmente como docentes, em escolas particulares de educação infantil e ensino fundamental. A distribuição dessas ocorrências por instituições se deu da seguinte maneira: FEUSP ( 3 casos); UNIBAN-Anhanguera ( 1 caso) e UNIFESP (3 casos).

A partir da exclusão dessas ocorrências, bem como daqueles que exerciam a docência no ambiente doméstico, também sem formação específica, foi possível obter o número real de docentes diplomados (no curso normal ou licenciatura) e que procuraram a graduação em Pedagogia como forma de continuidade do seu processo formativo, tal como ilustra o Quadro 6.1: 


\section{Quadro 6.1 - Distribuição dos respondentes docentes portadores de formação específica para o magistério.}

\begin{tabular}{cccc}
\hline FEUSP & PUC-SP & UNIBAN & UNIFESP \\
\hline $\begin{array}{c}\text { Licenciatura em Ciências Sociais (1); } \\
\text { Licenciatura em Dança (1), Licenciatura em } \\
\text { Filosofia (1); Licenciatura em História (2); } \\
\text { Licenciatura em Letras (4) }\end{array}$ & $\begin{array}{c}\text { Licenciatura em Filosofia (1); } \\
\text { Licenciatura em Música (1) e } \\
\text { Magistério/Normal (3) }\end{array}$ & $\begin{array}{c}\text { Licenciatura em Educação } \\
\text { Física (1) e }\end{array}$ & $\begin{array}{c}\text { Licenciatura em Ciências } \\
\text { Magistério/Normal (3) } \\
\text { História (2); Licenciatura em }\end{array}$ \\
Letras (2) e Magistério/Normal (2)
\end{tabular}

Iniciando a descrição pelos respondentes professores da FEUSP, seis atuavam no setor público, enquanto três eram professores de escolas particulares. Indagados a respeito do motivo que os levou ao curso de Pedagogia ${ }^{4}$, dois professores destacaram o interesse em aprender a alfabetizar, já que seus alunos estão iniciando o segundo ciclo do ensino fundamental sem o domínio da língua. Outros três professores expressaram o desejo pela formação continuada e por um espaço de reflexão sobre as questões educacionais. Por fim, duas professoras demonstraram o desejo de mudar de área de atuação: uma deixando a dança e aspirando ao trabalho na educação infantil, enquanto outra manifestou sua expectativa de usar o curso como estratégia para abandonar a sala de aula, atividade profissional que nunca teve em mente desempenhar:

“Na verdade, nunca quis ser professora e o estágio só veio confirmar isso quando da minha primeira graduação, contudo ingressei na rede municipal, por falta de opção e entrei na pedagogia para ter a futura possibilidade de sair da sala de aula, ou melhor, aumentar o campo de trabalho. Hoje, não pretendo prosseguir nessa carreira, devido a minha frustrada experiência na rede pública.” (Professora de História)

No relato da professora nota-se que inicialmente a mesma desejava ocupar cargos na administração escolar. Essa finalidade, apesar de não manifestada pelos outros professores ao responderem a pergunta sobre os motivos da frequência ao curso, também emergiu por parte de cinco deles quando falaram a respeito dos seus planos profissionais após o encerramento da graduação em Pedagogia. Entre estes, dois ainda gostariam de continuar lecionando e um deles pensava também em abrir uma escola. ${ }^{5}$

A professora de História, no final da sua resposta, destacou que seu plano inicial havia se modificado e que não pretendia mais atuar na rede pública de ensino. Porém, em termos

\footnotetext{
${ }^{4}$ Nesse momento da pesquisa, dos nove professores respondentes, dois abandonaram o questionário. Assim, a análise será realizada a partir da contribuição de sete docentes.

${ }^{5}$ É importante mencionar que os respondentes poderiam indicar mais de uma possibilidade de atuação profissional futura.
} 
formativos, a respondente demonstrou seu interesse em continuar estudando, agora no âmbito da pós-graduação, residindo aí sua nova expectativa de atuação profissional. Deve ser ressaltado que o plano de seguir na vida acadêmica foi indicado por todos os sete professores em questão, sendo este um indício significativo do modo como os mesmos pretendem utilizar da educação como estratégia de reconversão do capital cultural em outros mais rentáveis ou legítimos.

Apesar do interesse dos mesmos pela área de administração escolar como possibilidade de atuação profissional futura, apenas um professor mencionou a contribuição de uma disciplina do Departamento de Administração Escolar em sua formação profissional (Coordenação do Trabalho na Escola). Para os demais, as disciplinas que mais contribuíram com sua formação foram as que pertencem ao Departamento de Metodologia do Ensino (Currículos e Programas; Didática, Educação Infantil e metodologias em geral) e, em menor proporção, as disciplinas relacionadas com o Departamento de Filosofia da Educação (Psicologia da Educação; Filosofia da Educação e Sociologia da Educação).

Ao responderem a questão a respeito dos principais avanços e aprendizados adquiridos durante o curso, os professores ressaltaram a ampliação da capacidade de refletir sobre os temas educacionais, além de conhecerem melhor as características dos alunos mais jovens e seus modos de aprendizagem:

"Pude ampliar minha visão sobre a educação, embora muitas das matérias e discussões tenham sido "repetidas" inúmeras vezes. O curso permite que os alunos vejam os problemas educacionais por diversos ângulos."

"Conhecimento da mente infantil, como trabalhar com as crianças respeitando suas especificidades."

"A forma de pensar a educação e sua construção."

"Acredito que aprendi um pouco mais sobre a infância, suas peculiaridades e necessidades. Meu olhar sobre a criança mudou, não sabia que havia tanta complexidade nesta fase da vida."

Por fim, ao apresentarem suas representações acerca do que é ser professor, alguns docentes destacaram a formação pessoal de seus alunos e os processos de aprendizagem em torno da apropriação do conhecimento. Deve ser destacado, porém, o fato de dois docentes não conseguirem definir o sentido da profissão, enquanto a docente de História, mantendo seu tom de descontentamento, admitiu os limites de sua atuação profissional: “No meu caso, apenas uma gerenciadora de conflitos”. No caso destes três últimos docentes é possível notar o descontentamento e uma crise de identidade profissional, já que não conseguem relacionar seu 
trabalho com objetivo central da atividade docente, qual seja, lidar com o conhecimento e educar seus alunos.

"Não consigo definir."

“Ainda estou descobrindo.”

“Ajudar a construir conhecimento.”

"É ter o desejo de ensinar, a busca por ensinar e por aprender."

"É entender a escola como um importante lugar de transformação do indivíduo, buscando seu aprimoramento."

"Em grande parte é ser um provocador, para incentivar os estudantes a formarem suas próprias concepções de mundo.”

Entre os docentes da UNIFESP ${ }^{6}$, verificou-se que dois atuavam no setor público exclusivamente; um deles exercia a docência em escola particular; e três alegaram conciliar o trabalho no setor público e privado. O ingresso dos mesmos no curso de Pedagogia resultou de disposições diversas que envolveram a necessidade de complementar a formação prévia; a expectativa pela ampliação do campo de trabalho; por haver interesse pela área de estudo e pela função social da profissão:

“Função social.”

“Crença na educação como mecanismo de mudança social e cultural.”

“Realização profissional.”

"Meu interesse aumentou durante o curso anterior."

“Oportunidade de aprendizado e novas oportunidades no mercado de trabalho.”

"Identificação com a área.”

Em termos de projetos profissionais, foi possível identificar uma tendência entre os mesmos de se manterem na sala de aula (4/7), enquanto somente dois estudantes intencionavam o ingresso no âmbito da administração escolar. Diferentemente dos professores respondentes da FEUSP que destacaram a contribuição das disciplinas metodológicas, os docentes investigados da UNIFESP tenderam a reconhecer as disciplinas de formação teórica como aquelas que mais contribuíram com seu preparo profissional (Sociologia, Filosofia e História

\footnotetext{
${ }^{6}$ Dos sete professores titulados (magistério ou licenciatura), um abandonou o questionário. Assim, as análises ocorrerão a partir da contribuição de seis respondentes.
} 
da Educação). Essa preferência é ainda mais evidenciada quando os mesmos apresentam a contribuição do curso em seu processo formativo, já que praticamente todos docentes valorizaram a ampliação de sua formação teórica e de sua capacidade de compreensão dos temas educacionais:

“Ter opinião fundamentada.”

“Conhecimento teórico.”

“Acredito que o maior avanço foi realmente ter uma visão crítica a respeito da educação brasileira e pensar propostas que a modifiquem."

"Passei a entender melhor a rotina escolar e os trâmites que existem."

“Expansão da visão sobre o campo educacional, curiosidade pela pesquisa.”

“Conhecimento teórico e ampliação das possibilidades profissionais.”

No que se refere aos planos formativos após a conclusão do curso, os professores respondentes da UNIFESP destacaram o interesse pela pesquisa acadêmica (4/7), enquanto dois deles indicaram sua pretensão de frequentar cursos de especialização na área. Por fim, nas definições dos mesmos acerca do que é ser professor, foi possível notar a valorização dos objetivos de ensinar, lidar com conteúdos e formar seu alunado:

"Formar e transformar pessoas."

“Exercer um ofício; partilhar conhecimento; mediar relações.”

"Participar ativamente na formação de um indivíduo."

"Ser professor foi uma escolha e como todas que decidimos seguir vem acompanhada de uma grande responsabilidade, já que ela vai muito mais além da compreensão de transmitir conhecimentos, mas sim de construí-los juntamente com outras pessoas."

Entre os respondentes da UNIBAN-Anhanguera, portadores de formação específica para o exercício da docência, verificou-se que dois deles atuavam como funcionários públicos e outros dois eram professores em instituições particulares. O curso de Pedagogia foi procurado pela necessidade de complementar a formação adquirida no magistério e pelo desejo de obter o preparo necessário para a realização de seus planos profissionais, os quais estavam relacionados com a manutenção de suas funções docentes e com a expectativa de uma das alunas de fundar sua própria escola.

Em termos formativos, as professoras em questão valorizaram os conteúdos que mantiveram relação com a prática docente, tais como Didática, Prática de Ensino, Teoria e 
Prática da Educação, além da disciplina de Psicologia da Educação. Quanto às principais aprendizagens vivenciadas no curso, as docentes destacaram o ganho de conhecimento para o exercício de sua prática profissional, bem como na constituição de si próprias como estudantes mais qualificadas para a vida universitária:

“Adquiri mais segurança nas atividades desenvolvidas tanto durante o curso como no meu trabalho."

“Eu adquiri experiência na escrita e na leitura.”

“A aprendizagem sobre a forma de lidar com o outro, com as crianças.”

Finalmente, o modo como estas professoras representaram sua profissão envolveu a dimensão do valor do preparo docente para o desempenho do seu trabalho, a percepção do professor como mediador conhecimento e o ideário da profissão como missão:

"Ser professor é gostar de ser professor, é saber buscar os saberes para poder desenvolver da melhor maneira a sua profissão."

“Liderança, cabeça de um grupo, é um mediador."

“É além da profissão."

O último grupo de professores investigados pertence à PUC-SP, sendo todos funcionários de instituições particulares de ensino. Entre esses respondentes o curso de Pedagogia foi procurado por interessados pela área de estudo, bem como por aqueles que visavam ao seu aperfeiçoamento profissional e à aquisição de um perfil formativo que proporcionasse possibilidades específicas de atuação no campo educacional:

"O meu trabalho como docente, o interesse pela educação e o desejo de estabelecer relações entre as minhas formações iniciais e esta área de conhecimento."

"O meu trabalho como docente, o interesse pela educação e o desejo de estabelecer relações entre as minhas formações iniciais e esta área de conhecimento.”

“Busca por um maior aperfeiçoamento na profissão docente. Agregar currículo.”

"Trabalhar com formação de professores e ajudar a conscientizá-los sobre a importância da educação na estrutura do povo brasileiro."

“Amor pela educação das crianças.”

“A identificação com o curso.”

No que se refere ao processo de aprendizagem vivenciado na universidade, os professores respondentes destacaram a importância da formação teórica e a oportunidade de reflexão sobre a escola e acerca de suas vivências profissionais. O desenvolvimento dos modos 
de ensinar e a capacidade de melhor compreender os alunos também foram apontadas. Considerando-se as disciplinas que mais contribuíram em sua formação profissional, os alunos destacaram a contribuição dos conteúdos das matérias de Psicologia da Educação, Didática; Alfabetização; Gestão Educacional e Educação infantil.

Após a conclusão do curso, dois professores mostraram-se interessados em frequentar cursos de especialização, enquanto um deles pretendia seguir para área da pesquisa acadêmica. No que se refere às atividades profissionais, dois docentes intencionavam seguir atuando na sala de aula, enquanto os demais possuíam interesses diversos envolvendo a ação educacional em contextos diversificados e na área da administração escolar, bem como no âmbito da formação de professores.

As representações desses respondentes a respeito da profissão docente envolveram as noções de educação para a cidadania e para o desenvolvimento de valores, enquanto um dos investigados ressaltou aspectos relacionados com o comprometimento profissional ante os alunos, com o conhecimento e com o pensar:

“Criadores de bons cidadãos.”

“Trazer a todos a partir da educação a cidadania.”

"Pensar o presente, contribuir para o futuro em uma tarefa de educar através de conceitos, procedimentos e valores para a vida."

"É ajudar a conduzir, despertar o olhar para o mundo e colaborar para uma atuação consciente."

"Ser professor é estar comprometido com os seres humanos, as pessoas, com o momento presente, o conhecimento e a reflexão."

O detalhamento das motivações que levaram professores a frequentar o curso de Pedagogia nas quatro instituições investigadas permitiu reconhecer que os mesmos objetivavam principalmente a complementação de suas formações prévias, seguido pelo anseio de ampliação de suas oportunidades de atuação profissional. Entre as professoras da UNIBAN-Anhanguera a expectativa era a de continuar atuando em sala de aula, enquanto nas demais instituições os professores associavam ao interesse pela docência, projetos de trabalho na administração escolar, sobretudo entre os docentes da FEUSP. Estes últimos, são os que mais demonstraram suas estratégias de investimento escolar na luta contra a desvalorização de suas posições na estrutura de classes, seja pelo projeto de seguir uma carreira escolar ou pela continuidade dos estudos no âmbito da pós-graduação stricto sensu. Na UNIFESP, esse mesmo interesse se faz presente, devendo ser considerado, no caso de ambas instituições, a tradição das universidades 
públicas como locus de pesquisa. Entre os alunos das universidades particulares, a expectativa pela continuidade da formação se mantém, porém com uma tendência maior de procura pelos cursos de especialização.

No que se refere ao aproveitamento do curso, os docentes tenderam a valorizar as disciplinas de caráter metodológico, enquanto na UNIFESP e na FEUSP (nesta última, em menor proporção), destacou-se o interesse pelos conteúdos teóricos adquiridos, os quais foram creditados pela ampliação da capacidade dos docentes de refletirem e compreenderem mais aprofundadamente as questões educacionais. Na UNIBAN-Anhanguera, os professores indicaram ganhos em sua prática profissional, ao mesmo tempo que os mesmos notaram uma melhora na sua conduta como estudantes universitários. Por fim, na PUC-SP os professores estudantes indicaram a colaboração de disciplinas diversificadas em seu processo formativo, abrangendo as de caráter metodológico, assim como as de administração escolar e as de psicologia, enquanto ressaltaram o valor do curso no fornecimento de conceitos que ampliaram a consciência dos mesmos sobre o trabalho desempenhado e também acerca dos temas educacionais como um todo.

Por fim, as representações docentes sobre a profissão que exercem envolveu as dimensões do ensino e da aprendizagem, enquanto os respondentes da PUC-SP tenderam a valorizar aspectos como a formação para a cidadania e para a aquisição de valores. Merece ser sublinhada também a identificação de uma certa insatisfação entre os professores da FEUSP ao expressarem sua incapacidade de definir o que significa ser professor e, ao reduzir o sentido da profissão, ao mero gerenciamento de conflitos.

Nos capítulos anteriores foi realizado um trabalho no sentido de apresentar as especificidades dos respondentes investigados em cada uma das instituições. Suas características socioeconômicas e culturais foram demonstradas, bem como o modo de ingresso dos mesmos no curso de Pedagogia, considerando-se o processo de escolha profissional vivenciado. As expectativas profissionais e formativas após o encerramento do curso também foram retratadas, assim como seus modos de representação acerca da profissão docente.

O capítulo aqui concluído, num movimento analítico diverso do adotado nos anteriores, teve como objetivo realizar uma análise conjunta dos dados, identificando 
proximidades e distanciamentos entre os formandos envolvidos nesta pesquisa. Esse movimento foi possível pela compreensão em torno do fato de que as diferentes instituições, portadoras de características diversas, atraíram para si estudantes do curso de Pedagogia dotados de variados volumes de capital econômico e cultural. Essa heterogeneidade de origem social dos respondentes participou da constituição de seus habitus dirigindo desde suas práticas culturais, aos modos de escolha da universidade a ser frequentada, bem como seus planos formativos e profissionais após o término do curso. Por fim, o modo de representar a profissão também sofreu variações, ao mesmo tempo que apresentaram semelhanças entre os discursos. O último item do capítulo tratou do grupo de respondentes que mesmo estando em um curso de formação de professores, já exercia a docência e, por este motivo, nutria expectativas muito peculiares em relação ao curso, assim como planos de continuidade formativa e de atuação profissional. 


\section{CONSIDERAÇÕES FINAIS}

A investigação aqui desenvolvida foi motivada a partir de observações pessoais e empíricas a respeito do fato de muitos alunos do curso de Pedagogia de uma universidade particular dirigida às classes populares, onde tive a oportunidade de lecionar, frequentarem o curso sem que o mesmo tenha sido objeto de uma verdadeira escolha profissional. Essa constatação inicial produziu um conjunto de questões: por qual motivo alunos do curso de Pedagogia iniciam essa formação sem a posse de um interesse genuíno pelo mesmo? Como estes alunos, afinal, escolheram sua profissão? Seria esse desinteresse próprio dos alunos da instituição na qual eu atuava ou o mesmo teria ocorrência em outras universidades com características distintas?

Nessa mesma universidade onde lecionei, parte dos alunos do último ano do curso mantinham seu discurso de recusa em relação ao trabalho do pedagogo. Os mesmos mencionavam seu desinteresse pela atuação no meio escolar e na área educacional, de modo amplo. Muitos deles, ainda, apontavam a experiência do estágio como a principal motivação para a falta de expectativas de inserção profissional no âmbito da educação. Diante desse quadro, novas perguntas emergiram: com a posse do diploma, esses alunos não ingressariam mesmo que desinteressados - na área da educação? Desmotivados e tendo frequentado o curso sem essa previsão, não seriam esses alunos futuros professores pouco comprometidos com seu trabalho?

Uma primeira hipótese explicativa para esse quadro foi relacionada à desvalorização da profissão docente. Cruz (2013) destaca que o não reconhecimento do professor tem início dentro da própria rede pública de ensino, abrangendo desde o tratamento recebido nos dias de atribuição de aula, como na questão salarial e na desvalorização daqueles que se empenham em continuar seu processo formativo, ampliando suas qualificações profissionais. Morduchowicz (2003, p.12), em estudo acerca das estruturas salariais docentes, questiona a ausência de incentivo a esses profissionais quando a remuneração atribuída aos mesmos não considera seus conhecimentos e o trabalho desempenhado. Para o autor, um dos maiores pontos que justificam a mudança nos modos de planejamento das escalas salariais docentes deve-se ao fato de que "professores medíocres tenham a mesma remuneração que outros com melhor qualificação, preparação e compromisso com seus trabalhos. "Cruz (2013, p. 91) destacou ainda as más condições de trabalho e a violência escolar como fatores agravantes de desvalorização 
profissional, uma vez que "os professores exercem suas funções em condições adversas, o que certamente repercute na maneira como se percebem e são percebidos socialmente."

Sendo a profissão docente uma atividade desvalorizada, quem se interessaria por desempenhá-la? Ou melhor, para quem a formação em Pedagogia seria atrativa? Estudos acerca do perfil dos alunos dos cursos de licenciatura em Pedagogia indicam que os mesmos possuem sua origem social claramente associada às camadas populares, sendo os mesmos portadores de uma baixa formação escolar e cultural. De modo geral, a descrição desse alunado é elaborada genericamente, por meio de uma caracterização homogeneizadora dos mesmos. Porém, o exame do perfil socioeconômico e cultural dos estudantes do curso de Pedagogia associado a diferentes instituições formativas, tal como se propôs nesta investigação, permitiu a identificação de variações entre os respondentes.

O trabalho desenvolvido tendo em vista responder tais questionamentos envolveu, num primeiro momento, a escolha de universidades portadoras de características diversas, tais como: histórico de criação; princípios formativos e finalidades institucionais; tempo de funcionamento e tradicionalismo; estratégia de seleção dos alunos ingressantes; localização do campus; nível de abrangência no espaço acadêmico; e valor da mensalidade, no caso das instituições particulares. A partir destes critérios, foram selecionadas para participar desta pesquisa as seguintes instituições: Faculdade de Educação da Universidade de São Paulo (FEUSP), Universidade Federal de São Paulo (UNIFESP), Pontifícia Universidade Católica de São Paulo (PUC-SP) e Universidade Bandeirante Anhanguera (UNIBAN-Anhanguera), campus Morumbi. A perspectiva adotada foi a de que a diversidade das instituições seria também acompanhada da diversificação do perfil de seus alunos, permitindo assim a verificação da ocorrência de variações de resultados para as questões orientadoras da pesquisa. Assim, as motivações de ingresso no curso de Pedagogia entre os alunos da Pontifícia Universidade Católica de São Paulo, cuja mensalidade custa aproximadamente R \$ 1.200,00, seria a mesma dos alunos da Universidade Bandeirante Anhanguera, instituição em que a mensalidade atinge aproximadamente o valor de R $\$ 400,00$ ? Do mesmo modo, alunos que frequentam o curso de Pedagogia em universidades públicas como a USP e a UNIFESP, ingressam nessas graduações movidos por quais interesses? Os estudantes dessas quatro universidades partilham dos mesmos modos de escolha profissional? Em quais aspectos esses estudantes se aproximam e se distanciam em termos de origem social, práticas culturais, planos profissionais, formativos e representações sobre a profissão docente? 
Tendo em vista a obtenção de respostas para tais questionamentos, o segundo momento da pesquisa envolveu, portanto, a aplicação de um questionário junto aos formandos do curso de Pedagogia das quatro universidades. Os dados obtidos a partir da colaboração dos respondentes foram organizados em uma planilha excel, passando por estudo de análise estatística e pelo entrecruzamento de informações por meio do recurso "tabela dinâmica" do próprio editor de planilhas utilizado. O exame dos dados, a partir do apoio de referencial teórico fundamentado na sociologia de Pierre Bourdieu, permitiu a produção de informações que atendem aos objetivos da pesquisa e que serão retomadas a seguir.

No que se refere à origem social, verificou-se que os alunos menos privilegiados em termos de posse de capital econômico e cultural encontram-se na UNIBAN-Anhanguera. Os respondentes da UNIFESP apresentam-se a seguir, havendo entre os mesmos uma ligeira elevação da renda per capita, acompanhada por um maior nível formativo materno (ensino médio) e uma trajetória escolar marcada pelo ensino público, porém cursado em maior número no período matutino. Entre os respondentes da FEUSP e PUC-SP foi possível notar uma nova elevação do nível formativo dos genitores, com significativa presença de pais com nível universitário, ao mesmo tempo que foi observada a elevação da renda per capita familiar, com destaque nesse aspecto para os alunos da PUC-SP. Ainda entre estes dois grupos de respondentes, foi possível notar um maior número de egressos de escolas particulares e uma ocorrência menor de alunos que tiveram de trabalhar durante o ensino médio.

A variação na posse do volume global do capital cultural e econômico distribui os agentes em diferentes frações de classe, sendo os mesmos portadores de um habitus que afeta suas disposições em termos de práticas e representações. Entre os respondentes das quatro universidades, foi possível notar que a elevação do capital cultural e econômico tendeu a fortalecer nos agentes suas estratégias de investimento escolar, como recurso de reprodução da posição ocupada pelos mesmos no interior da estrutura social. Assim, enquanto os agentes pertencentes a famílias menos escolarizadas e detentoras de uma condição econômica limitada tenderam a guiar suas escolhas formativas a partir de critérios práticos (valor da mensalidade; tempo de dedicação ao curso e processo seletivo), tal como ocorreu entre os alunos da UNIBAN-Anhanguera, a elevação do capital cultural e econômico favoreceu entre os demais um processo de escolha institucional voltada para a dimensão da qualidade formativa e para os ganhos simbólicos que o diploma a ser obtido poderia proporcionar.

De acordo com Bourdieu (1996), o espaço social é estruturado a partir da distribuição dos agentes de acordo com o volume global dos seus capitais, havendo um peso significativo 
dos capitais cultural e econômico. Esse espaço é retraduzido nos agentes sob a forma de disposições, ou seja, do habitus. Quanto mais próxima for a localização dos agentes no espaço social, mais similares serão seus modos de ação e pensamento. Como consequência, foi possível observar entre os formandos investigados a ocorrência de práticas culturais que os aproximaram e, por vezes, marcaram distâncias, como resultado da variação na posse do volume dos capitais detidos.

Iniciando pelas práticas culturais comuns, verificou-se a recorrência das atividades realizadas no âmbito doméstico (acessar a internet, assistir televisão, ler e ouvir música), sendo o cinema a prática de lazer externa mais mencionada, apesar de pouco frequente. No que se refere aos hábitos de leitura e filmes assistidos, foi identificada uma forte propensão ao consumo dos livros mais vendidos (best sellers) e pela produção cinematográfica popularizada (blockbusters). A leitura de jornais e revistas foi pouco frequente e os títulos mencionados, de modo geral, indicavam os periódicos de maior circulação no país (Veja, Nova Escola, O Estado de S. Paulo e Folha de S. Paulo). Ou seja, notou-se, como característica geral dos respondentes das quatro universidades, um baixo interesse pelas práticas culturais, havendo ainda uma clara preferência pelo consumo de bens culturais massificados.

Por outro lado, as práticas culturais dos respondentes também indicaram certas especificidades. Os alunos da UNIBAN-Anhanguera, por conta do baixo volume de capital cultural, demonstraram ter dificuldade em indicar o título do último livro lido, bem como os nomes dos jornais e revistas que eventualmente costumavam ler. Os filmes registrados como os mais recentemente assistidos no cinema eram desatualizados, além de não conseguirem indicar de modo claro os nomes dos seus museus preferidos. Em contrapartida, os respondentes da PUC-SP, FEUSP e UNIFESP tiveram mais facilidade para indicar o nome das suas últimas leituras, além de parte dos mesmos conseguir citar livros especializados em diversas áreas do conhecimento. No que se refere à leitura de periódicos, alguns dos respondentes da PUC-SP, FEUSP e UNIFESP mencionaram seu interesse por jornais internacionais e revistas de caráter não comercial, por vezes, portadoras de conteúdos especializados em arte, cinema, esportes ou viagens.

A diferenciação das práticas culturais observadas demonstraram guardar relação com a condição social de origem dos agentes. Em alguns casos, foi mais evidente a contribuição do capital econômico, como por exemplo, a assistência a peças de teatro de grande divulgação, a realização de práticas esportivas e viagens. Em outras circunstâncias, a posse relativamente elevada do capital econômico e do capital cultural favoreceu a assistência a filmes europeus e 
a prática de leituras mais seletas, tanto no que se refere às obras de literatura como a jornais e revistas.

Quanto ao processo de escolha profissional, os dados indicaram que a UNIBANAnhanguera compreendia o maior número de respondentes que tinham no curso de Pedagogia sua primeira opção formativa, seguida pela PUC-SP. Na FEUSP foi elevado o número de respondentes que afirmaram ser essa graduação sua segunda opção. Entretanto, esse número resultou do fato dessa instituição reunir a maior quantidade de alunos que já iniciaram outra graduação anteriormente. Por fim, merece ser destacado o fato da UNIFESP reunir o maior índice de respondentes que trocaram a profissão inicialmente desejada pelo curso de Pedagogia.

O perfil dos alunos que tinham a graduação em Pedagogia como sua primeira opção formativa também foi delineado. Como resultado, verificou-se uma predisposição maior ao curso dos respondentes que: a) trabalharam durante o ensino médio, sendo este cursado no período noturno; b) possuíam mães portadoras de menor nível de escolaridade e que se ocupavam de atividades manuais; c) pertenciam a famílias com renda per capita familiar de até um salário mínimo; e d) dedicavam-se com baixa frequência às atividades de leitura. Esse resultado deve ser analisado considerando-se a forte contribuição da UNIBAN-Anhanguera no delineamento do mesmo.

As justificativas empregadas para explicar o abandono do curso inicialmente desejado pelo curso de Pedagogia abrangeram principalmente restrições de caráter objetivo envolvendo limitações financeiras e formação cultural insuficiente para aprovação no vestibular para o curso desejado. Deste modo, o processo de escolha profissional ocorreu a partir das condições sociais de origem dos agentes, cujo habitus, marcado pelos condicionamentos primários, orientou as decisões e as expectativas profissionais, produzindo práticas viáveis no interior dos limites das condições de vida dos respondentes investigados.

Quanto ao estudo das motivações que conduziram os respondentes das quatro universidades ao curso de Pedagogia, foram verificadas três grandes justificativas: a) identificação pessoal com a profissão; b) interesses profissionais; e c) engajamento social. No primeiro grupo estão situados os alunos que possuem características pessoais entendidas como apropriadas ao desempenho da profissão, tais como facilidade para ensinar e gostar de crianças. No segundo grupo destacam-se os argumentos dos respondentes que veem na docência um amplo campo de atuação profissional, seja numa perspectiva de afastamento das dificuldades na obtenção de emprego ou como estratégia de construção de uma carreira profissional no 
âmbito da educação. Por fim, o discurso engajado que relaciona o trabalho educacional ao processo de mudança da sociedade também foi apresentado como motivo de escolha do curso.

Deve ser destacado o fato da perspectiva social da profissão ser novamente apresentada no momento em que os respondentes informam suas representações acerca do trabalho docente. Assim, do mesmo modo que uma parcela dos alunos da FEUSP, PUC-SP e UNIFESP optou pelo curso de Pedagogia pela valorização da função social imbuída na profissão, notou-se a tendência por parte desses formandos em definirem a figura docente como a de um agente portador de uma forte consciência de suas responsabilidades diante da sociedade, cabendo ao mesmo formar alunos pensantes e dotados de senso crítico. O segundo modo mais recorrente de representação da profissão tem relação com a apresentação das funções pedagógicas do professor, sendo clara a rejeição por parte dos alunos das posturas docentes relacionadas a um modo de atuação compreendido como tradicional. Assim, a imagem do professor como um mediador do processo de aprendizagem foi significativamente frequente entre os formandos investigados de todas as instituições.

Finalmente, o levantamento dos planos profissionais e formativos dos alunos ofereceram indícios de que, mesmo entre os respondentes que não tinham o curso de Pedagogia como sua primeira opção, há um generalizado interesse pelo exercício da docência. Por outro lado, nas situações em que a sala de aula é recusada, ainda assim se faz presente o interesse pela permanência na área educacional, por meio do desempenho de atividades diversificadas. Os planos formativos dos alunos reforçam mais uma vez o interesse desses respondentes pela profissão, já que existia uma significativa expectativa entre os mesmos de darem continuidade ao seu processo formativo por meio da frequência a cursos de pós-graduação. 


\section{REFERÊNCIAS BIBLIOGRÁFICAS}

ALMEIDA, G. de. O professor que não ensina. São Paulo: Summus, 1986.

ALMEIDA, M. E. B de; IANNONE, L. R; SILVA, M. da G. M. Educação a distância: oferta, características e tendências dos cursos de Licenciatura em Pedagogia. Estudos \& Pesquisas Educacionais. São Paulo: Fundação Victor Civita, 2012. Disponível em: $<$ http://www.fvc.org.br/estudos-e-pesquisas/2011/relatoriofinal.pdf $>$. Acesso em: 20 nov. 2013

ALMEIDA, W. M. de. Ampliação do Acesso ao Ensino Superior Privado Lucrativo Brasileiro: um Estudo sociológico com Bolsistas do Prouni na Cidade de São Paulo, tese de doutorado, FFLCH/USP, São Paulo, 2012.

ANTUNHA, H. C. G. As origens da Faculdade de Educação da USP - A introdução dos estudos pedagógicos de nível superior no Estado de São Paulo. Revista da Faculdade de Educação, São Paulo, FEUSP, v. 1, n. 1, p.225-42, 1975.

ARROYO, M. G. Mestre, educador, trabalhador. Organização do trabalho e profissionalização. Belo Horizonte, UFMG, 1985.

AUAD, D.; NOVAES, L. C. A expansão do ensino superior público na UNIFESP: a turma inaugural de Pedagogia. RBPAE, v.24, n.1, p. 153-172, jan./abr. 2008.

AVELINO, Y. D. Reminiscências acadêmicas na trajetória da Pontifícia Universidade Católica de São Paulo - PUC-SP. In: SCHERER, O. P. (org.). PUC-SP: 65 anos de história, tradição e vanguardismo, 1946-2011. São Paulo: EDUC, 2011.

BARBOSA, F. Práticas culturais, interesses e legitimidade. In: JLeiva Cultura \& Esporte. Cultura em SP: hábitos culturais dos paulistas. São Paulo: Tuva Editora, 2014.

BARREYRO, G. B. Mapa do ensino superior privado. Brasília: Instituto Nacional de Estudos e Pesquisas Educacionais Anísio Teixeira, 2008.

BASSO, I. Significado e sentido do trabalho docente. Caderno Cedes. Campinas, ano IXI, n. 44, p. 19-32, 1998.

BENETTI, M.; HAGEN, S. Jornalismo e imagem de si: o discurso institucional das revistas semanais. Estudos em Jornalismo e Mídia, n. 1, jan./jun. 2010. Disponível em: $<$ http://periodicos.ufsc.br/index.php/jornalismo>. Acesso em: 04 mai. 2015.

BIANCHINI, N. As ausências de conhecimentos manifestos na formação de professorasalunas de curso normal superior, dissertação de mestrado, UNESP, Araraquara, 2005.

Distinção: efeito de trajetória social, tese de doutorado, PUC-SP, São Paulo, 2011.

BITTAR, M. O ensino superior privado no Brasil e a formação do segmento das universidades comunitárias. Avaliação, Campinas, v. 6, n. 2, p. 33-42, 2001. 
BÓGUS, L.; PASTERNAK, S. A distribuição dos equipamentos culturais e os processos de segregação na cidade de São Paulo: o acesso à cultura na urbe metropolitana. In: Anais do XI Congresso Luso Afro Brasileiro de Ciências Sociais. UFBA, 2001.

BORGES, J. L. das G.; CARNIELLI, B. L. Educação e estratificação social no acesso à universidade pública. Cadernos de Pesquisa, v. 35, n. 124, jan./abr. 2005. Disponível em:< http://www.scielo.br/pdf/cp/v35n124/a0735124.pdf>. Acesso em: 19 fev. 2015.

BOTELHO, I. Os equipamentos culturais na cidade de São Paulo: um desafio para a gestão pública. Espaço e Debates - Revista de Estudos regionais e urbanos, n.43/44. 2004. Disponível em: < http://www.fflch.usp.br/centrodametropole/198>. Acesso em: 09 mai. 2015.

BOTELHO, I.; FIORE, M. O uso do tempo livre e as práticas culturais na região metropolitana de São Paulo. Centro de Estudos da Metrópole. Relatório de Pesquisa. São Paulo, 2005.

BOURDIEU, P. (org.). A miséria do mundo. Petrópolis: Editora Vozes, 2008.

. A distinção - crítica social do julgamento. São Paulo: Edusp, 2007 b.

. A economia das trocas simbólicas. São Paulo: Perspectiva, 2013.

. Coisas ditas. São Paulo: Brasiliense, 2004.

. Esboço de uma teoria da prática. In: ORTIZ, R. (org.). A sociologia de Pierre Bourdieu. São Paulo: Olho d'Água, 2003a.

. Escritos de educação. Petrópolis, RJ: Editora Vozes, 2013.

. Gostos de classe e estilos de vida. In: ORTIZ, R. (org.). A sociologia de Pierre Bourdieu. São Paulo: Olho d'Água, 2003b.

. O poder simbólico. RJ: Bertrand Brasil, 2010.

. O que falar quer dizer - a economia das trocas linguísticas. Lisboa: Difel, 1998.

. Razões práticas - sobre a teoria da ação. Campinas, SP: Papirus, 1996.

BOURDIEU, P.; DARBEL, A. O amor pela arte: os museus de arte na europa e seu público. 2. ed. São Paulo: EDUSP, 2007a.

BOURDIEU, P.; PASSERON, J. C. Os herdeiros: os estudantes e a cultura. Florianópolis: Ed. da UFSC, 2014.

BRANDÃO, D. F. Você quer ser professor? Um estudo sobre o interesse de licenciandos em pedagogia pela profisssão docente, dissertação de mestrado, UFS, 2012.

BRASIL. Ministério da Educação. Plano Nacional de Educação. Brasília, DF: Senado Federal, 2001. Disponível em: $<$ http://portal.mec.gov.br/arquivos/pdf/pne.pdf $>$. Acesso em: 15 set. 2013. 
BRASIL. Ministério da Educação/INEP. Resumo Técnico - Censo da Educação Superior de 2009. Brasília, DF: 2010. Disponível em: $<$ http://download.inep.gov.br/download/superior/censo/2009/resumo tecnico2009.pdf $>$.

Acesso em: 28 nov. 2013.

BRAVERMAN, H. Trabalho e capital monopolista - A degradação do trabalho no século XX. Rio de Janeiro: Zahar Editores, 1980.

BRAZ, A. M. G. Teorias implícitas dos estudantes de pedagogia sobre a docência nos anos iniciais do ensino fundamental, tese de doutorado, UFRN, 2006.

BRZEZINSKI, I. Pedagogia, pedagogos e formação de professores: busca e movimento. Campinas: Papirus, 1996.

CAMPOS, M. R. Ator ou protagonista? Dilemas e responsabilidades sociais da profissão docente. Revista PRELAC - Projeto Regional de Educação para a América Latina e o Caribe (UNESCO). Santiago, n. 1, p. 6 -23, jun., 2005.

CARLOTTO, M. C. Universitas semper reformanda? A história da Universidade de São Paulo e o discurso da gestão à luz da estrutura social, tese de doutorado, Faculdade de Filosofia, Letras e Ciências Humanas da USP, 2014.

CARLOTTO, M. C.; GARCIA, S. G. Tensões e contradições do conceito de organização aplicado à universidade: o caso da criação da USP-Leste. Avaliação, Campinas; Sorocaba, v. 18, n. 3, p. 657-684, nov. 2013.

CATANI, A. M; HEY, A. P. A Universidade de São Paulo (USP) e a formação de quadros dirigentes. In: MOROSINI, M. (org.). A Universidade no Brasil: concepções e modelos. Brasília: Instituto Nacional de Estudos e Pesquisas Educacionais Anísio Teixeira, 2006.

CATANI, A. M; OLIVEIRA, J.F. A educação superior. In: OLIVEIRA, R. P.; ADRIÃO, T. (Org.). Organização do ensino no Brasil: níveis e modalidades na Constituição Federal e na LDB. 2.ed. São Paulo: Xamã, 2007. p.73-84.

CATANI, D. B. e. al. História, memória e autobiografia na pesquisa educacional e na formação. In: _. Docência, Memória e Gênero: estudos sobre formação. São Paulo: Escrituras, 1997, p. $\overline{13-47}$.

CEPÊDA, V. A.; MARQUES, A. C. H. Um perfil sobre a expansão do ensino superior recente no Brasil: aspectos democráticos e inclusivos. Perspectivas, São Paulo, v. 42, p. 161-192, jul./dez. 2012.

CHAMLIAN, H. C. Currículo do curso de Pedagogia na USP. Revista da Faculdade de Educação, São Paulo, v. 22, no 22, p. 131-157, jul./dez. 1996.

CHAMPAGNE, Patrick. Pierre Bourdieu. Toulouse: Les essentiels de Milan, nº 297, 2008.

CHARLES, F.; CLÉMENT, J-P. Comment deviant-on enseignant? L'IUFM et ses publics. Presses Universitaires de Strasbourg, 1997. 
CHARTIER, R. O mundo como representação. Estudos Avançados, n.11, v. 5, p. 173-91, jan./abr. 1991.

CHIANN, C.; MITSUUCHI, E. Y.; SATO, A. B. A. Relatório de análise estatística sobre o projeto: "Caracterização dos formandos do curso de licenciatura em Pedagogia e de suas representações acerca da profissão docente". São Paulo: IME-USP, 2014 (RAE-CEA-14P19).

CRUZ, L. L. da. Ascensão pelo estudo ou estagnação qualificada? Os sentidos da experiência do projeto Bolsa Mestrado para os professores da rede estadual de São Paulo (2004-2009), tese de doutorado, Faculdade de Educação da USP, 2013.

Magistério e cultura: a formação cultural dos professores e sua percepção das potencialidades educativas dos museus de arte, dissertação de mestrado, PUC-SP, 2008.

CUNHA, L. A. Desenvolvimento desigual e combinado no ensino superior - estado e mercado. Educação \& Sociedade, Campinas, v. 25, n. 88, out. 2004. Disponível em $<$ http://www.cedes.unicamp.br>. Acesso em: 05 jan. 2012.

. Ensino superior e universidade no Brasil. In: LOPES, E. M. T.; FARIA FILHO, L. M. de; VEIGA, C. G. (orgs.). In: 500 anos de educação no Brasil. Belo Horizonte: Autêntica, 2000. p. 151-204.

. O ensino superior no octênio FHC. Educação \& Sociedade, Campinas, vol. 24, n. 82, p. 37-61 - abr. 2003. Disponível em <http://www.cedes.unicamp.br>. Acesso em: 05 jan. 2012.

DINIZ, M. de F. C. O(a) acadêmico(a) do curso de pedagogia e suas expectativas profissionais no século XXI: Um estudo com os alunos(as) do Curso de Pedagogia 2006/2009 da Faculdade Padrão do Município de Goiânia-Goiás, dissertação de mestrado, PUC/Goiânia, 2010 .

DOURADO, L. F.; OLIVEIRA, J. F. de. Educação superior: o público e o privado na produção do trabalho e da vida acadêmica. In: ADRIÃO, T.; PERONI, V. (orgs.). O público e o privado na educação: interfaces entre estado e sociedade. São Paulo: Xamã, 2005.

DURHAM, E. R. O ensino superior no Brasil: público e privado. Documento de Trabalho, n. 3/03. São Paulo: Núcleo de Pesquisas sobre Ensino Superior da Universidade de São Paulo, 2003.

EARP, F. de Sá; PAULANI, L. M. Mudanças no consumo de bens culturais no Brasil após a estabilização da moeda. Nova Economia, v. 24, n. 3, p. 469-490, 2014.

ENGE, J. S. Da universidade ao mundo do trabalho: um estudo sobre o início da profissionalização de egressos do curso de licenciatura da USP (1994-1995), dissertação de mestrado, FEUSP, 2004.

FERNANDES ENGUITA, M. A ambiguidade da docência: entre o profissionalismo e a proletarização. Teoria \& Educação, Porto Alegre, n.4, p.41-60, 1991.

FÉTIZON, B. A. de M. Educar professores? Um questionamento dos cursos de licenciatura da Universidade de São Paulo, dissertação de mestrado, FEUSP, 1978. 
. Faculdade de Educação: antecedentes e origens. Estudos Avançados, São Paulo, v. 8, n. 22, p.365-73, 1994.

FORJAZ, M. C. S. Lazer e consumo cultural das elites. Revista Brasileira de Ciências Sociais, São Paulo, v. 3, n. 6, p. 99-113, 1988.

GATTI, B. A. (coord); BARRETO, E. S. de Sá. Professores do Brasil: impasses e desafios. Brasília: UNESCO, 2009.

GATTI, B. A. (et. al.). A atratividade da carreira docente no Brasil. Estudos \& Pesquisas Educacionais - n. 1, maio - Fundação Victor Civita: São Paulo, 2010.

GOLDSTEIN, I. S.; SILVA, L. S. Tempo livre: sentidos e definições. In: JLeiva Cultura \& Esporte. Cultura em SP: hábitos culturais dos paulistas. São Paulo: Tuva Editora, 2014.

GOMES, I. C. R. Formação de professores de $1^{\text {a }}$ a $4^{\text {a }}$ série do ensino fundamental nas modalidades a distância e presencial: um estudo na Universidade Federal do Espírito Santo, tese de doutorado, UFMG, 2007.

GOUVEIA, A. J. Professôras de amanhã: um estudo de escolha ocupacional. 2. ed. São Paulo: Livraria Pioneira Editôra, 1970.

GUIMARÃES, K. T. O perfil dos alunos do curso de Pedagogia da UNESP de Bauru (20072010). Monografia (Graduação), UNESP (Bauru), 2010.

HEYMANN, L; ALBERTI, V. (Orgs.). Trajetórias da Universidade privada no Brasil: depoimentos ao CPDOC-FGV. Brasília, DF.: CAPES; Rio de Janeiro: FGV/CPDOC, 2002. 2 v. il.

INSTITUTO NACIONAL DE ESTUDOS E PESQUISAS EDUCACIONAIS ANÍSIO TEIXEIRA (Inep). Exame Nacional do Ensino Médio (Enem): fundamentação teóricometodológica. Brasília, 2005. Disponível em: <www.inep.gov.br>. Acesso em: 03 jan. 2012.

INSTITUTO NACIONAL DE ESTUDOS E PESQUISAS EDUCACIONAIS ANÍSIO TEIXEIRA (Inep). Estudo exploratório sobre o professor brasileiro com base nos resultados do Censo Escolar da Educação Básica 2007. Brasília, 2009. Disponível em:< http://portal.mec.gov.br/dmdocuments/estudoprofessor.pdf>. Acesso em: 27 jul. 2015.

ISHII, I.; KRASILCHIK, M.; LEITE, R. C. Diversidade de alunos: o caso da USP. Revista de Educação Pública, Cuiabá, v. 23, n. 54, p. 681-700, set./dez. 2014.

JLEIVA CULTURA \& ESPORTE. Cultura em SP: hábitos culturais dos paulistas. São Paulo: Tuva Editora, 2014.

KOGA, Y. M. N. Meritocracia e docência: um objeto multifacetado, doutorado em educação, PUC-SP, 2013.

. Magistério e distinção: um estudo sobre as trajetórias das professoras ganhadoras do prêmio Professores do Brasil no meio oeste de Santa Catarina, mestrado em educação, PUCSP, 2009. 
LASNE, A. Da-C. La singulière réussite scolaire des enfants d'enseignants: des pratique éducatives parentales spécifiques? Thèse de doctorat, Université de Bourgogne, 2013.

LAWN, M.; OZGA, J. O trabalho docente: interpretando o processo de trabalho do ensino. Teoria \& Educação, Porto Alegre, n.4, 1991. Dossiê: interpretando o trabalho docente, p.140158.

LEITE, Y. U. F; LIMA, V. M. M. Cursos de Pedagogia no Brasil: o que dizem os dados do INEP/MEC? Ensino Em-Revista, Uberlândia, v.17, nº1, p. 69-93, jan/jun. 2010.

LEME, L. F. Atratividade do magistério para o ensino básico: estudo com ingressantes de cursos superiores da Universidade de São Paulo. 2012. 192 f. Dissertação de Mestrado Faculdade de Educação da Universidade de São Paulo, São Paulo, 2012.

Perfil e expectativas de ingressantes do curso de pedagogia da Universidade de São Paulo e a atratividade da carreira docente. Faculdade de Educação da Universidade de São Paulo (TCC). SP: s.n, 2009.

LENHARO, M. Enfrentar o preconceito: a prova mais difícil do ProUni. Jornal da Tarde, 29 nov. 2010. Disponível em: <http://educacao.estadao.com.br/noticias/geral,enfrentar-opreconceito-a-prova-mais-dificil-do-prouni,646839>. Acesso em: 22 jul. 2015.

LOURO, G. L. Gênero e magistério: identidade, história, representação. In: CATANI, D. B. et. al. (org.). Docência, Memória e Gênero: estudos sobre formação. São Paulo: Escrituras, 1997, p. 77-84.

LOUZANO, P. et. al. Quem quer ser professor? Atratividade, seleção e formação docente no Brasil. Est. Aval. Educ., São Paulo, v. 21, n. 47, p. 543-568, set./dez. 2010.

LUGLI, R. S. G. O novo público do ensino superior brasileiro e a tradição acadêmica: o caso das humanidades na UNIFESP (Universidade Federal de São Paulo). Revista Linhas. Florianópolis, v. 15, n. 29, p. 297-316, jul./dez. 2014.

MARIN, A. J. Formação de professores: novas identidades, consciência e subjetividade. In: TIBALl I, E. F. A.; CHAVES, S. M. (Org.). Concepções e práticas em formação de professores: diferentes olhares. Rio de Janeiro: DP \&A, 2003.

MARTINS, C. B. A reforma universitária de 1968 e a abertura para o ensino superior privado no Brasil. Educação e Sociedade, Campinas, v. 30, n. 106, p. 15-35, jan./abr. 2009.

MILLS, C. W. A nova classe média (White Collar). RJ: Zahar Editores, 1969.

MORDUCHOWICZ, A. Carreiras, incentivos e estruturas salariais docentes. Documentos. PREAL - Programa de promoção da reforma educativa na América Latina e Caribe, $n^{0}$ 23, jun., 2003.

MORICONI, G. M. Os professores públicos são mal remunerados nas escolas brasileiras? Uma análise da atratividade da carreira do magistério sob o aspecto da remuneração, dissertação de mestrado, FGV, São Paulo, 2008. 
NAKAGAWA, C. T. Reflexos sociais e impactos territoriais: tipologias e espacialização dos equipamentos de cultura e lazer, dissertação de mestrado, Faculdade de Arquitetura e Urbanismo, Universidade de São Paulo, São Paulo, 2011.

NEVES, F. M. O método Lancasteriano e o ensino da ordem e da disciplina para os soldados do império brasileiro. Anais da $3^{\mathrm{a}}$ Reunião Anual da Associação Nacional de PósGraduação e Pesquisa em Educação, 2007. Disponível em: http://www.anped.org.br/reunioes/30ra/trabalhos/gt02-3119--int.pdf. Acesso em 07 nov. 2013.

NOGUEIRA, C. M. M. Dilemas na análise sociológica de um momento crucial das trajetórias escolares: o processo de escolha do curso superior, tese de doutorado, Faculdade de Educação, Universidade Federal de Minas Gerais, 2004.

NÓVOA, A. Para o estudo sócio-histórico da gênese e desenvolvimento da profissão docente. Teoria \& Educação, Porto Alegre, n. 4, p. 109-139, 1991.

OLIVEIRA, L. R. Estudo do projeto de vida profissional de alunos universitários do curso de pedagogia, dissertação de mestrado, UNICAMP, 2001.

OLIVEIRA, R. P. A transformação da educação em mercadoria no Brasil. Educação \& Sociedade, Campinas, v. 30, n. 108, p. 739-760, out. 2009.

ORGANIZAÇÃO PARA COOPERAÇÃO E DESENVOLVIMENTO ECONÔMICO (OCDE). Professores são importantes: atraindo, desenvolvendo e retendo professores eficazes. São Paulo: Moderna, 2006.

PAULA, M. de F. C. de. USP e UFRJ a influência das concepções alemã e francesa em suas fundações. In: Tempo Social, São Paulo, v. 14, n. 2, p. 147-161, out. 2002.

PENNA, M. G. de O. Exercício docente: posições sociais e condições de vida e trabalho de professores. São Paulo: Fapesp, 2011.

PEREIRA, G. R. de M. Servidão ambígua: valores e condições do magistério. SP: Escrituras Editora, 2001.

PEREIRA, J. E. D. Formação de professores: pesquisa, representações e poder. Belo Horizonte: Autêntica, 2006.

PEREIRA, L. O magistério primário numa sociedade de classes - Estudo de uma ocupação em São Paulo. SP: Livraria Pioneira Editora, 1969.

PESSANHA, E. C. Ascensão e queda do professor. São Paulo: Cortez, 1994.

PETTERS, L. C. F. Trajetórias e expectativas de jovens universitários: um estudo sobre os processos identitários dos jovens do curso de Pedagogia na relação educação, trabalho e ações coletivas, dissertação de mestrado, UNIVALI, 2009.

PONTIFÍCIA UNIVERSIDADE CATÓLICA DE SÃO PAULO. Faculdade de Educação. Projeto Pedagógico do Curso de Pedagogia. São Paulo, SP, 2006. 
POULOGIANNOPOULOU, P. Comment devient-on enseignant? De l'expérience universitaire à la formation, Thèse de sciences de l'éducation, Université Paris Descartes, 2012.

RAYOU, P.; ZANTEN, A. V. Enquête sur les nouveaux enseignants: Changeront-ils l'école? Paris: Éditions Bayard, 2004.

RIBEIRO, B. Cultura urbana: movimento, inovação e convergência. In: JLeiva Cultura \& Esporte. Cultura em SP: hábitos culturais dos paulistas. São Paulo: Tuva Editora, 2014.

ROMANELLI, O. de O. História da educação no Brasil (1930/1973). Petrópolis: Editora Vozes, 2001.

SALEM, T. Do Centro D. Vital à Universidade Católica. In: SCHWARTZMAN, S. (org.). Universidades e Instituições Científicas no Rio de Janeiro. Brasília: CNPq, 1982, p. 97 134.

SALLES NETO, L. L.; CRUZ, F. M da; CESPEDES, J. G. O perfil socioeconômico e cultural dos estudantes da UNIFESP: um estudo inicial realizado com base em dados de ingressantes 2011. Universidade Federal de São Paulo. Pró-reitoria de Assuntos Estudantis. 2012.

SAMPAIO, H. O setor privado de ensino superior no Brasil: continuidades e transformações. Revista Ensino Superior Unicamp, Campinas, Ed. n. 4, p. 28-43, out. 2011.

SANDANO, W.; VENANZI, D. Universidades comunitárias: as características na prestação de serviços públicos. Revista Temas em Educação, João Pessoa, v. 23, n. 2, p. 140-155, jul./dez. 2014.

SCHEIBE, L.; AGUIAR, M. A. Formação de profissionais da educação no Brasil: o curso de Pedagogia em questão. Educação \& Sociedade, nº6, dez., 1999, p. 220 - 238.

SCHEIBE, L.; DURLI, Z. Curso de Pedagogia no Brasil: olhando o passado, compreendendo o presente. Educação em Foco, Belo Horizonte, UEMG, nº 17, jul. 2011, p.79-109.

SCHMIDT, J. P. O comunitário em tempos de público não estatal. Avaliação, Campinas; Sorocaba, SP, v. 15, n. 1, p. 9-40, mar. 2010.

SCHWARTZMAN, S.; CASTRO, M. H. M. Carreiras universitárias na USP. Núcleo de Pesquisas sobre Ensino Superior da USP, com apoio da Fundação de Amparo à Pesquisa de São Paulo (FAPESP), São Paulo: NUPES, 1992. (Documento de Trabalho)

SÉCCA, R. X.; LEAL, R. M. Análise do setor de ensino superior privado no Brasil. Rio de Janeiro: BNDES Setorial, n. 30, p. 103-156, 2011.

SETTON, M. da G. J. A divisão interna do campo universitário: uma tentativa de classificação. Revista Brasileira de Estudos Pedagógicos, Brasília, v. 80, n. 196, p. 451-471, set/dez. 1999.

Professor: um gosto de classe, dissertação de mestrado, PUC-SP, 1989.

SILVA, C. S. B. da. Diretrizes curriculares para o curso de Pedagogia no Brasil: um tema vulnerável às investidas ideológicas. In: BRZEZINSKI, I. (org.). Profissão professor: identidade e profissionalização docente. Brasília: Plano Editora, 2002, p.75-93. 
SILVA, J. de S. A formação e o trabalho docente: um estudo das teorizações acerca das dimensões pessoais no exercício da profissão, dissertação de mestrado, FEUSP, 2012.

SILVA, M. C. da. Quem quer ser professor? Uma análise social, econômica e cultural dos alunos de Pedagogia de uma universidade particular paulista. In: Anais do XI Congresso Nacional de Educação - EDUCERE, 2013. Disponível em:< http://educere.bruc.com.br/ANAIS2013/pdf/11269_6373.pdf> Acesso em: 26 jun. 2015.

SOUSA, S. Z.; OLIVEIRA, R. P. O curso de pedagogia FEUSP - perfil de ingressantes, trajetória acadêmica e destino profissional dos formandos. Avaliação - Revista da Avaliação da Educação Superior, Campinas, v. 3, n. 3, p. 61-71, set. 1998.

SOUZA, A. C. de. Os significados de ser e formar-se professor: saberes mobilizados na formação em um curso de pedagogia, tese de doutorado, PUC-SP, 2010.

SOUZA, L. de O. Motivações para a escolha da Licenciatura em Matemática e Pedagogia: um estudo com alunos da PUC/SP e UFMT, dissertação de mestrado, PUC/SP, 2010.

SOUZA, S. S. de O. Construção identitária do pedagogo em formação: elementos simbólicos constelados na incerteza da escolha profissional, dissertação de mestrado, UFBA, 2009 .

TANURI, L. M. História da formação de professores. Revista Brasileira de Educação, $\mathrm{n}^{\mathrm{o}}$ 14, mai-ago, 2000, p. 61 - 88.

UNESCO. O perfil dos professores brasileiros: o que fazem, o que pensam, o que almejam. Pesquisa Nacional, Unesco, São Paulo: Editora Moderna. 2004.

UNIVERSIDADE BANDEIRANTE DE SÃO PAULO. Projeto Pedagógico do Curso de Direito - Campus Marte. São Paulo, SP, 2013.

UNIVERSIDADE DE SÃO PAUlO. Faculdade de Educação. Projeto Político Pedagógico do Curso de Licenciatura Plena em Pedagogia. São Paulo, SP, 2011.

UNIVERSIDADE FEDERAL DE SÃO PAULO. Conselho Universitário (CONSU). Estatuto da Universidade Federal de São Paulo. São Paulo, SP, 2010.

UNIVERSIDADE FEDERAL DE SÃO PAULO. Escola de Filosofia, Letras e Ciências Humanas. Projeto Pedagógico do Curso de Pedagogia. São Paulo, SP, 2010.

UNIVERSIDADE FEDERAL DE SÃO PAULO. Proposta REUNI da Universidade Federal de São Paulo (UNIFESP) ao Programa de Apoio a Planos de Reestruturação e Expansão das Universidades Federais - REUNI. São Paulo, SP, 2008. Disponível em: $<$ http://www.unifesp.br/prograd/portal/index.php?option=com_docman\&task=cat_view\& gid $=232 \&$ Itemid $=260>$. Acesso em: 13 set. 2013 .

VALLE, I. R. Carreira do magistério: uma escolha deliberada? Revista Brasileira de Estudos Pedagógicos, Brasília, v. 87, n. 216, p. 178-187, maio/ago. 2006. 
VICENTINI, P. P.; LUGLI, R. G. História da profissão docente no Brasil: representações em disputa. São Paulo: Cortez, 2009.

VILLELA, H. de O. S. Do artesanato à profissão: saberes de normalistas no Brasil do século XIX. Anais da 26 ${ }^{\mathbf{a}}$ reunião anual ANPED, 2003. Disponível em: $<$ www.anped.org.br/reunioes/26/trabalhos/heloisadeoliveirasvillela.rtf $>$. Acesso em: 08 nov. 2013.

ZAGO, N. Do acesso à permanência no ensino superior: percursos de estudantes universitários de camadas populares. Revista Brasileira de Educação, v. 11, n. 32, mai-ago. 2006, p. 226 237. 
ANEXo-A

QUESTIONÁRIO APLICADO PARA O

LEVANTAMENTO DE DADOS 


\section{Caracterização dos estudantes do curso de Licenciatura em}

\section{Identificação}

*1. Em qual instituição de ensino você cursa a graduação em Pedagogia?

Faculdade de Educação da Universidade de São Paulo (FEUSP).

Pontifícia Universidade Católica de São Paulo (PUC/SP).

Uniban/Anhanguera Educacional.

Universidade Federal de São Paulo (Unifesp).

\section{*2. Qual o seu sexo?}

$\int$ Feminino.

Masculino.

* 3. Qual a sua idade? (Por favor, escreva apenas os números)

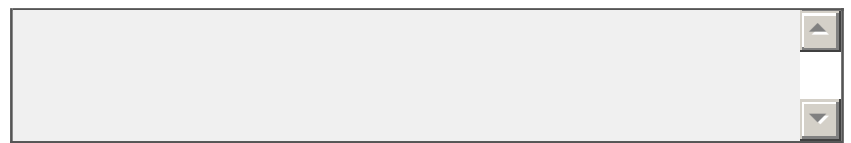

\section{*4. Como você se considera:}

Amarelo(a) (de origem oriental).

Branco(a)

Indígena ou de origem indígena.

Pardo(a)/mulato(a).

$\bigcirc \operatorname{Preto}(a)$.

\section{*5. Qual seu estado civil?}

Solteiro(a).

Casado(a) / mora com um(a) companheiro(a).

Separado(a) / divorciado(a).

Viúvo.

\section{*6. Quantos filhos você tem?}

Nenhum.

Oum.

$\bigcirc$ Dois.

Três.

Mais de três filhos. 


\section{Caracterização dos estudantes do curso de Licenciatura em}

* 7. Você possui quantos irmãos mais velhos?

0

$\bigcirc_{1}$

$\bigcirc 2$

$\mathrm{O}_{3}$

4 ou mais.

* 8. Você possui quantos irmãos mais novos?

$\bigcirc 0$

$\bigcirc$

O2

3

4 ou mais.

\section{Trajetória Escolar}

* 9. Em que tipo de escola você cursou o ensino fundamental ( $\left.1^{\circ} \mathrm{grau}\right)$ :

Todo em escola pública

Todo em escola privada (particular)

A maior parte em escola pública.

A maior parte em escola privada (particular).

Metade em escola pública e metade em escola privada (particular).

* 10. Em que tipo de escola você cursou o ensino médio $\left(2^{\circ} \mathrm{grau}\right)$ :

Todo em escola pública.

Todo em escola privada (particular).

A maior parte em escola pública.

A maior parte em escola privada (particular).

Metade em escola pública e metade em escola privada (particular).

\section{* 11. Em qual Estado você concluiu o ensino médio?}




\section{Caracterização dos estudantes do curso de Licenciatura em}

* 12. Qual foi a modalidade do ensino médio que você cursou?

Ensino médio regular.

Educação para jovens e adultos (antigo supletivo).

Ensino técnico/ensino profissional (eletrônica, contabilidade, agrícola, etc.).

Curso normal/magistério.

\section{*13. Em qual período você cursou o ensino médio?}

Período matutino.

Período noturno.

*14. Você trabalhou ou teve alguma atividade remunerada durante seus estudos no ensino médio?

Sim, todo o tempo.

Sim, menos de um ano.

Sim, de 1 a 2 anos.

Sim, de 2 a 3 anos.

Sim, mais de 3 anos.

Não.

*15. Quantas horas você trabalhava durante seus estudos no ensino médio?

Sem jornada fixa, até 10 horas semanais.

De 11 a 20 horas semanais.

De 21 a 30 horas semanais.

De 31 a 40 horas semanais.

Mais de 40 horas semanais.

* 16. Nessa época, com que finalidade você trabalhava enquanto estudava?

Para ajudar meus pais nas despesas com a casa, sustentar a família.

Para meu sustento e o de minha família (esposo/a, filhos/as etc.).

Para ser independente (ter meu sustento, ganhar meu próprio dinheiro).

Para adquirir experiência.

Para ajudar minha comunidade.

Outra finalidade (especifique) 


\section{Caracterização dos estudantes do curso de Licenciatura em}

*17. Se você trabalhou durante seus estudos, com que idade você começou a exercer atividade remunerada?

Antes dos 14 anos.

Entre 14 e 16 anos.

$\bigcirc$ Entre 17 e 18 anos

Após 18 anos.

* 18. Você se preparou, por quanto tempo, em algum cursinho pré-vestibular?

Não

Sim, menos de um semestre.

$\bigcirc$ Sim, um semestre completo.

Sim, de um semestre a um ano.

Sim, de um ano a um ano e meio

Sim, de um ano e maio a dois anos.

Sim, mais de dois anos.

* 19. Qual foi o tipo de cursinho que você fez?

Cursinho particular.

Cursinho popular de custo reduzido.

Cursinho popular gratuito.

\section{*20. Em qual período você frequentou o cursinho?}

Período matutino.

Período vespertino.

Período noturno.

Outro (especifique) 


\section{Caracterização dos estudantes do curso de Licenciatura em}

* 21. Qual foi o intervalo entre sua conclusão do ensino médio e o ingresso no ensino superior?

Menos de um ano.

Um ano.

$\bigcirc$ Dois anos.

$\bigcirc$ Três anos

Quatro anos.

Cinco anos ou mais.

\section{* 22. Você já começou algum outro curso superior?}

Não.

Sim, mas abandonei.

Sim e já conclui.

Especifique o nome do curso que você já concluiu anteriormente:

\section{Dimensão sociocultural}

\section{* 23. Qual o grau de instrução mais alto que seu pai obteve?}

Não frequentou escola

Ensino fundamental: $1^{\circ}$ ao $5^{\circ}$ ano (antiga $1^{\text {a }}$ à $4^{\mathrm{a}}$ série ou antigo primário) incompleto

Ensino fundamental: $1^{\circ}$ ao $5^{\circ}$ ano (antiga $1^{a}$ à $4^{a}$ série ou antigo primário) completo.

Ensino fundamental: $6^{\circ}$ ao $9^{\circ}$ ano (antiga $5^{\mathrm{a}}$ à $8^{\mathrm{a}}$ série ou antigo ginásio) incompleto.

Ensino fundamental: $6^{\circ}$ ao $9^{\circ}$ ano (antiga $5^{a}$ à $8^{a}$ série ou antigo ginásio) completo.

Ensino médio (antigo $2^{\circ}$ grau) incompleto.

Ensino médio (antigo $2^{\circ}$ grau) completo.

Ensino superior incompleto.

Ensino superior completo.

Pós-graduação.

$\bigcirc$ Não sei. 


\section{Caracterização dos estudantes do curso de Licenciatura em}

\section{*24. Qual o grau de instrução mais alto que sua mãe obteve?}

Não frequentou escola.

Ensino fundamental: $1^{\circ}$ ao $5^{\circ}$ ano (antiga $1^{\mathrm{a}}$ à $4^{\mathrm{a}}$ série ou antigo primário) incompleto.

Ensino fundamental: $1^{\circ}$ ao $5^{\circ}$ ano (antiga $1^{\text {a }}$ à $4^{\text {a }}$ série ou antigo primário) completo.

Ensino fundamental: $6^{\circ}$ ao $9^{\circ}$ ano (antiga $5^{\text {a }}$ à $8^{\text {a }}$ série ou antigo ginásio) incompleto.

Ensino fundamental: $6^{\circ}$ ao $9^{\circ}$ ano (antiga $5^{\mathrm{a}}$ à $8^{\mathrm{a}}$ série ou antigo ginásio) completo.

Ensino médio (antigo $2^{\circ} \mathrm{grau}$ ) incompleto.

Ensino médio (antigo $2^{\circ}$ grau) completo.

Ensino superior incompleto.

Ensino superior completo.

Pós-graduação.

Não sei.

*25. Em que seu pai trabalha ou trabalhou, na maior parte da vida?

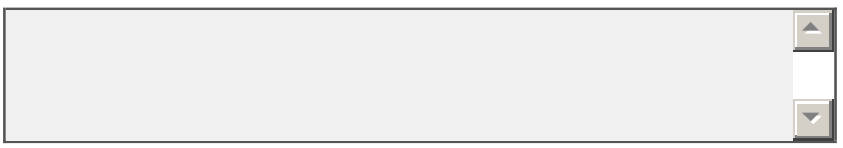

*26. Em que sua mãe trabalha ou trabalhou, na maior parte da vida?

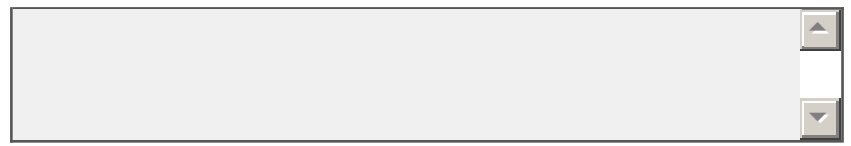

\section{Características socioeconômicas}

\section{* 27. Qual é a sua faixa de renda familiar mensal em salários mínimos? (Considere a} renda de todos que moram na sua casa.)

Inferior a 1 salário mínimo (até $\mathrm{R} \$ 678,00$ inclusive).

Entre 1 e 2 salários mínimos (de $R \$ 678,00$ até $R \$ 1.356,00$ inclusive).

Entre 2 e 3 salários mínimos (de $R \$ 1.356,00$ até $R \$ 2.034,00$ inclusive).

Entre 3 e 5 salários mínimos (de $R \$ 2.034,00$ até $R \$ 3.390,00$ inclusive).

Entre 5 e 7 salários mínimos (de $R \$ 3.390,00$ até $R \$ 4.746,00$ inclusive).

Entre 7 e 10 salários mínimos (de $\mathrm{R} \$ 4.746,00$ até $\mathrm{R} \$ 6.780,00$ inclusive).

Entre 10 e 14 salários mínimos (de $R \$ 6.780,00$ até $R \$ 9.492,00$ inclusive).

Entre 14 e 20 salários mínimos (de RS 9.492,00 até $R \$ 13.560,00$ inclusive).

Acima de 20 salários mínimos (acima de 13.560,00). 


\section{Caracterização dos estudantes do curso de Licenciatura em}

* 28. Quantas pessoas contribuem para a obtenção dessa renda familiar?
Uma.
Duas.
Três.
Quatro.
Cinco ou mais.

* 29. Quantas pessoas são sustentadas com a renda familiar?
Uma.
Duas.
Três.
$\bigcirc$ Quatro.
Cinco.
Seis.
Sete.
Oito ou mais.

* 30. A casa em que você vive é:
Própria.
Alugada.

* 31. Você trabalha atualmente?

$\bigcirc \operatorname{sim}$

Não

* 32. Qual é a sua atividade profissional? 


\section{Caracterização dos estudantes do curso de Licenciatura em}

\section{* 33. Qual é o tipo de vínculo empregatício?}

Bolsista mantido por agência financiadora.

Empregado celetista.

Empregado público estatutário.

Empregado público celetista.

Estágio profissional.

Trabalhador cooperado.

Empregado doméstico.

Prestador de serviços.

Trabalho voluntário.

Contratato de trabalho sem vínculo empregatício: trabalho eventual, trabalho avulso, trabalho temporário, trabalho autônomo.

Outro (especifique)

\section{* 34. Qual é o seu rendimento mensal?}

Não tenho rendimentos.

Inferior a 1 salário mínimo (até $\mathrm{R} \$ 678,00$ inclusive).

Entre 1 e 2 salários mínimos (de $R \$ 678,00$ até $R \$ 1.356,00$ inclusive).

Entre 2 e 3 salários mínimos (de $R \$ 1.356,00$ até $R \$ 2.034,00$ inclusive).

Entre 3 e 5 salários mínimos (de $R \$ 2.034,00$ até $R \$ 3.390,00$ inclusive).

Entre 5 e 7 salários mínimos (de $R \$ 3.390,00$ até $R \$ 4.746,00$ inclusive).

Entre 7 e 10 salários mínimos (de $R \$ 4.746,00$ até $R \$ 6.780,00$ inclusive).

Entre 10 e 14 salários mínimos (de $R \$ 6.780,00$ até $R \$ 9.492,00$ inclusive).

Entre 14 e 20 salários mínimos (de RS 9.492,00 até R\$13.560,00 inclusive).

Acima de 20 salários mínimos (acima de 13.560,00).

\section{* 35. Indique sua atual carga horária de trabalho:}

Sem jornada fixa, até 10 horas semanais.

De 11 a 20 horas semanais.

De 21 a 30 horas semanais.

De 31 a 40 horas semanais.

Mais de 40 horas semanais. 


\section{Caracterização dos estudantes do curso de Licenciatura em}

\section{* 36. Em qual turno você cursou a maior parte da sua graduação?}

Diurno.

$\bigcirc$ Noturno.

\section{Condições de ingresso no ensino superior}

* 37. Você recebe ou recebeu algum tipo de bolsa de estudos ou financiamento para custear as mensalidades do curso?
$\bigcirc \operatorname{sim}$.
Não se aplica - meu curso é gratuito.
Não.

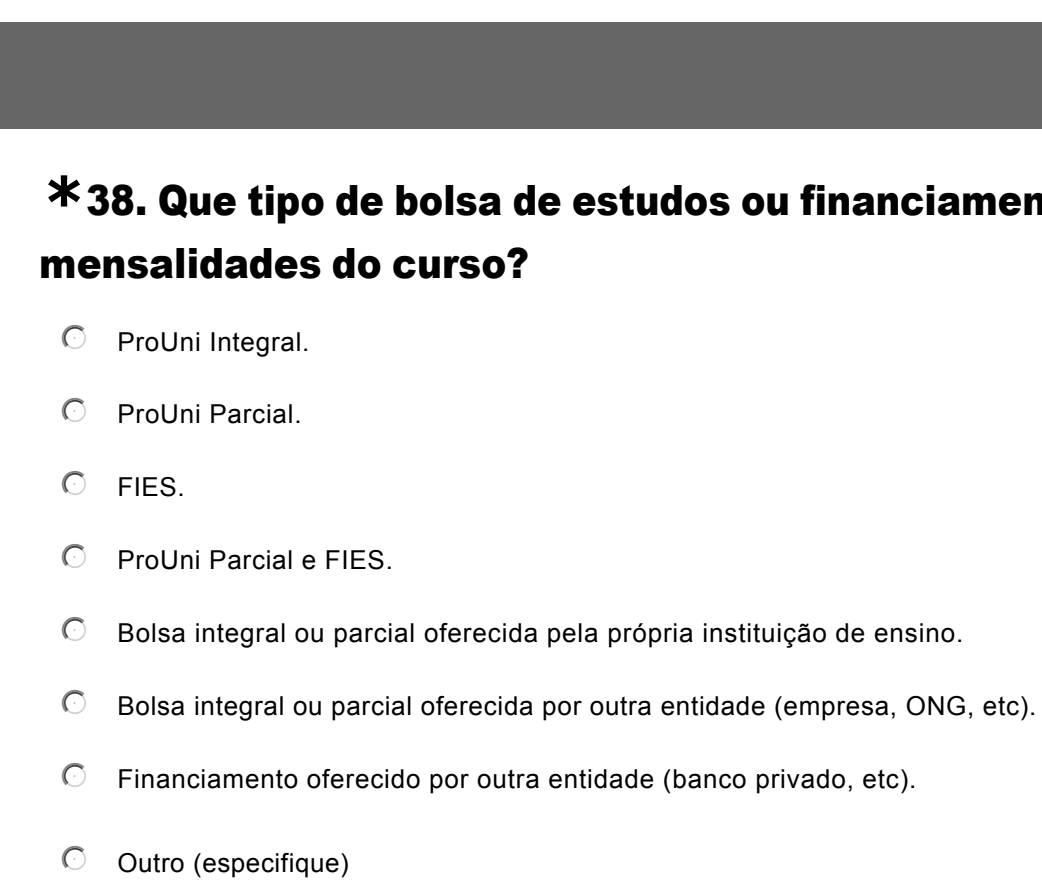

* 39. Seu ingresso no curso de graduação se deu por meio de políticas de ação afirmativa?
Não.
Sim, por critério etnico-racial (negros, pardos e indígenas).
Sim, por critério de renda.
Sim, por ter estudado em escola pública ou particular com bolsa de estudo.
Sim, por sistema que combina dois ou mais critérios anteriores.
Sim, por sistema diferente dos anteriores. 


\section{Caracterização dos estudantes do curso de Licenciatura em}

\section{Em qual município você mora?}

Guarulhos.

São Paulo.

Outro (especifique)

* 41. Se você vive em São Paulo, assinale o bairro no qual você mora:

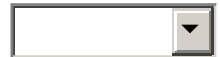

* 42. Se você vive em Guarulhos, indique o bairro no qual você mora:

* 43. Que meio de transporte você utiliza com mais frequência para chegar à universidade:

A pé.

Transporte coletivo (ônibus, metrô, trem, etc.).

Veículo próprio.

Carona.

* 44. Quanto tempo você usa para chegar à Universidade?

Menos de 30 minutos.

Entre 30 e 60 minutos.

Entre 1 e 2 horas.

Mais de 2 horas.

\section{Estágio}

* 45. Você realizou que tipo de estágio durante o curso de graduação:

Fiz somente o estágio obrigatório.

Além do estágio obrigatório, eu também realizei estágio remunerado em uma instituição de ensino.

Além do estágio obrigatório, eu também atuei como estagiário(a) em instituição de caráter não educacional.

Indique o nome da instituição na qual você realizou seu estágio não obrigatório. 


\section{Caracterização dos estudantes do curso de Licenciatura em}

* 46. 0 estágio alterou suas expectativas sobre seu futuro profissional? Por quê?

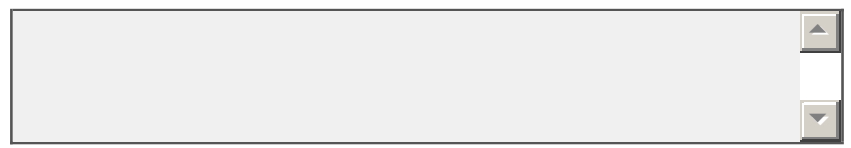

* 47. Relate uma experiência marcante vivenciada por você durante o estágio.

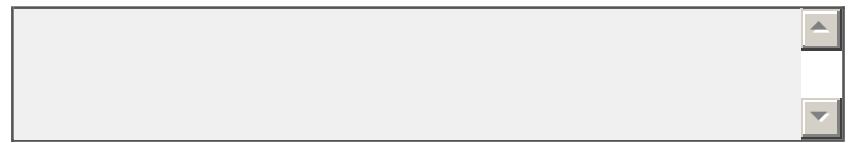

\section{Escolha e expectativas profissionais}

* 48.0 curso que você está seguindo foi sua primeira opção de formação profissional?

$\bigcirc \operatorname{sim}$

Não.

Neste caso, informe qual era a sua primeira opção:

* 49. Caso tenha respondido não na questão anterior, explique o que motivou essa mudança.

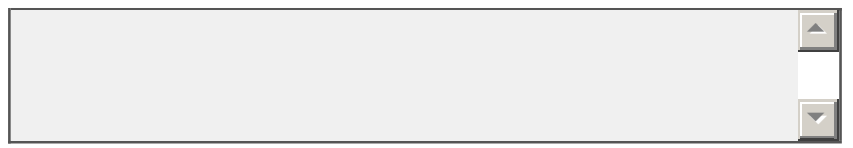

* 50. Seus familiares apoiam sua opção de cursar esta graduação?

sim.

Não

* 51. Quais foram as razões que o levou a frequentar o curso de graduação em pedagogia?

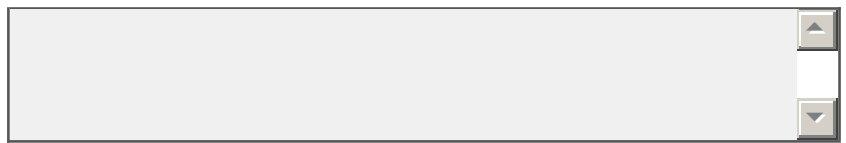

* 52. Na sua opinião, qual foi a disciplina (ou disciplinas) que mais contribuiu com a sua formação em Pedagogia? 


\section{Caracterização dos estudantes do curso de Licenciatura em}

* 53. Durante o curso, quais foram as principais dificuldades enfrentadas por você?

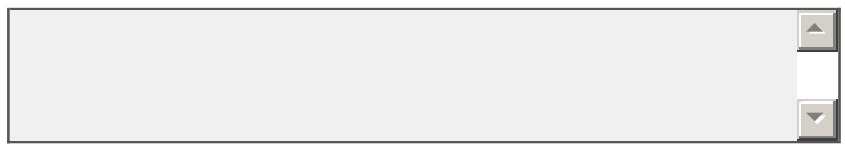

*54. Na sua opinião, quais foram os principais avanços e aprendizados adquiridos por você durante 0 curso?

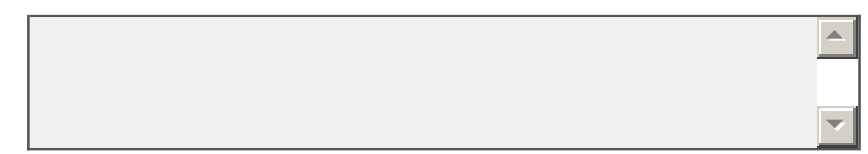

\section{* 55. Depois de formado o que você deseja fazer profissionalmente?}

Prestar concurso público para trabalhar como professor de educação infantil ou do ensino fundamental.

Trabalhar como professor de educação infantil ou do ensino fundamental em escola particular.

Trabalhar em instituição educacional no atendimento de crianças com necessidades educativas especiais.

Trabalhar em cargos de gerenciamento escolar (Coordenação Pedagógica, Direção escolar) em escolas particulares ou via concurso público.

Abrir uma escola.

Trabalhar com educação, em contexto diversificado: hospitais, terceiro setor (ONGs), empresas privadas (recursos humanos),

assessoria pedagógica, difusão cultural (feiras, museus...).

T Trabalhar em outra área que não se relacione com a educação.

Outro (especifique)

\section{*56. Após concluir a graduação, você pretende:}

Cursar outra graduação.

Frequentar um curso de especialização para aprofundamento dos conhecimentos obtidos na graduação.

Frequentar um curso de especialização em uma área totalmente distinta da formação obtida na graduação.

Desenvolver pesquisa no âmbito do mestrado.

Não pretendo continuar estudando.

Caso tenha assinalado a primeira ou a terceira opção, indique o nome do curso escolhido.

\section{Hábitos culturais}




\section{Caracterização dos estudantes do curso de Licenciatura em}

* 57. Entre as atividades abaixo, assinale aquelas que você pratica em seu tempo livre:

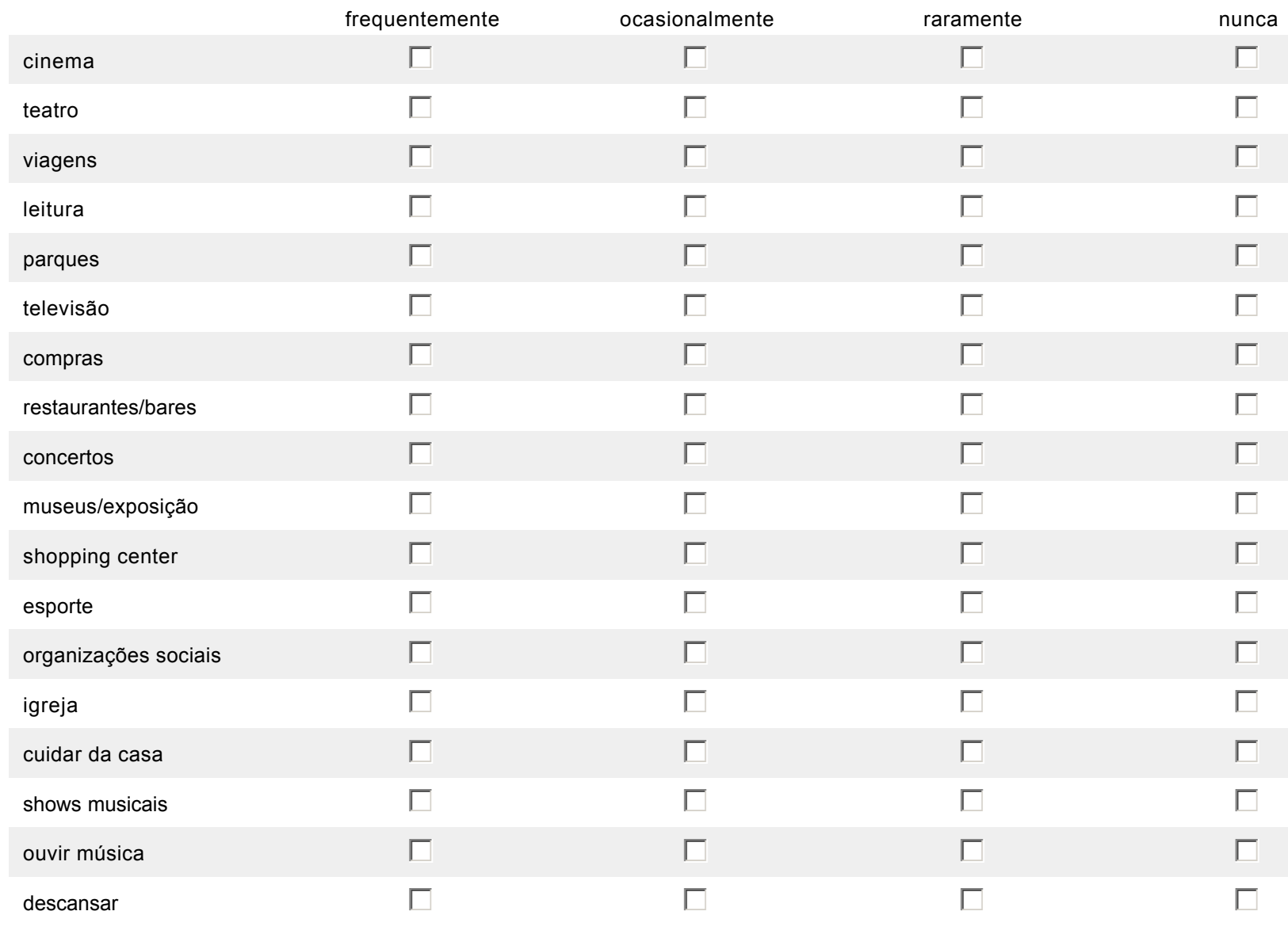

* 58. Qual foi o último filme que você assistiu no cinema? Caso não se recorde, escreva "Não me lembro" na caixa de texto.

* 59. Qual foi a última peça de teatro que você assistiu? Caso não se recorde, escreva "Não me lembro" na caixa de texto.

*60. Dentre os museus que você já visitou, qual deles você mais gostou de frequentar? Caso não se recorde, escreva "Não me lembro" na caixa de texto. 


\section{Caracterização dos estudantes do curso de Licenciatura em}

\section{*61. Você costuma ler livros?}

muito.

pouco

regularmente.

não leio.

* 62. Qual foi o último livro que você leu? Caso não se recorde, escreva "Não me lembro" na caixa de texto.

*63. Você costuma ler revistas?

$\bigcirc$ Muito.

Pouco.

Regularmente.

Não leio.

64. Qual(is) revistas você costuma ler?

*65. Você costuma ler jornais?

Muito.

Pouco.

Regularmente.

Não leio.

66. Qual(is) jornal(is) você costuma ler? 


\section{Caracterização dos estudantes do curso de Licenciatura em}

* 67. Entre os programas de televisão, qual você prefere assistir?

Debates

Documentários

Esportes

Filmes

Jornais

Novelas

Seriados

Variedades

Outro (especifique)

* 68. Que tipo de música você mais gosta?

$\bigcirc$ Blues

Forró

Funk

$\bigcirc$ Gospel

Jazz

Música clássica

Música eletrônica

Música popular brasileira

$\bigcirc$ Pagode

Pop

$\bigcirc \operatorname{Rap}$

Rock

Samba

Sertanejo

Outro (especifique)

* 69. Com qual frequência você pratica atividade física?

Diariamente.

Semanalmente.

Raramente.

Nunca. 


\section{Caracterização dos estudantes do curso de Licenciatura em}

70. Caso pratique alguma atividade física, indique a modalidade:

\section{*71. Você domina alguma língua estrangeira?}

$\bigcirc \operatorname{sim}$

Não

* 72. Você toca algum instrumento musical?

$\bigcirc \operatorname{sim}$

Não

* 73. Você acessa a internet:

Frequentemente

Raramente.

Nunca.

\section{* 74. Seu local de maior acesso à internet é:}

aparelhos eletrônicos móveis.

domicílio de outras pessoas.

em casa.

em centro de acesso gratuito ou pago.

na universidade.

no trabalho.

* 75. A maior parte do tempo você utiliza a internet para:

Compras.

Envio ou leitura de emails.

$\bigcirc$ Estudo.

Lazer.

Leitura de notícias.

Sociabilidade (redes sociais)

Trabalho.

Utilização de mecanismos de busca. 


\section{Caracterização dos estudantes do curso de Licenciatura em}

\section{* 76. Qual a sua religião?}

Budismo.

Candoblé.

Católica.

Espírita.

Evangélica

Hinduísmo

Judaísmo

Mórmon.

Novas religiões orientais

Sem religião.

Testemunha de Jeová.

Tradições esotéricas.

Tradições indígenas.

Umbanda

Outro (especifique)

\section{Questões gerais}

77. Com qual partido político você mais se identifica?

* 78. Você é a favor ou contra:

Sou a favor.

Sou contra.

Não tenho opinião definida.

Aborto

Pena de morte

Políticas afirmativas
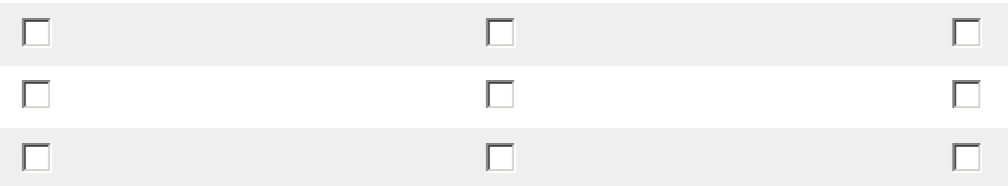

* 79. Para você o que é ser professor?

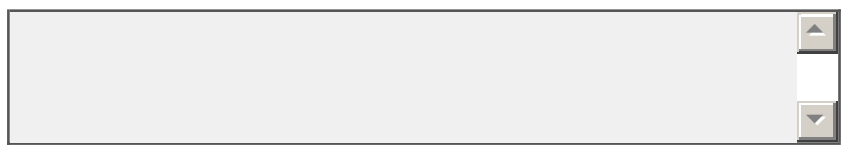

80. Que profissão você gostaria que seu filho(a) tivesse? 


\section{Caracterização dos estudantes do curso de Licenciatura em}

81. Esta pesquisa terá um segundo momento, no qual você poderá ser entrevistado. Caso tenha interesse em participar, indique um telefone e/ou email para contato.

Telefone

Email 


\section{APÊNDICE - A}

\section{DESCRIÇÃO DETALHADA DAS INSTITUIÇÕES}

INVESTIGADAS 


\section{Universidade Bandeirante AnHanguera}

A história de surgimento da Universidade Bandeirante Anhanguera está vinculada à fundação da Faculdade Anchieta, cujos primeiros cursos - Filosofia e Ciências Sociais - foram criados nos anos de 1954 e 1960, respectivamente. O processo de ampliação e diversificação da formação oferecida que se deu a seguir é explicado pela instituição como resultado do interesse em atender a demanda por formação no ensino superior, existente na região da Zona Norte de São Paulo. Assim, em 1971, foram criados os cursos de Pedagogia, Matemática, Letras e História, vinculados à Faculdade Paulista de Ciências, Letras e Educação, ocorrendo o reconhecimento dos mesmos entre os anos de 1974 e 1975 (Universidade Bandeirante de São Paulo, 2013.).

Nos anos seguintes foram fundados cursos na área de saúde e administração, abrangidos pela Faculdade Paulista de Ciências da Saúde e Faculdade Paulista de Administração. Já na década de oitenta, a Academia Paulista Anchieta, passou a manter a Faculdade Paulista de Arte; a Faculdade de Ciências e Letras de Moema; a Faculdade de Filosofia Nossa Senhora Medianeira e a Faculdade Dom Domênico. Tais faculdades foram unificadas pelo Conselho Federal de Educação em 1988, dando origem ao Centro de Ensino Unificado Bandeirante (CEUB). As aquisições das faculdades isoladas e a constituição do CEUB respondiam ao interesse institucional em reunir o número de cursos exigidos pelo Conselho Federal de Educação, para que fosse possível a abertura de uma universidade. Em 1992 foi realizada a solicitação de reconhecimento do CEUB como universidade, o qual foi emitido no final do ano de 1993, dando-se a homologação no ano seguinte, quando a instituição passou a ser denominada por Universidade Bandeirante de São Paulo - UNIBAN (HEYMANN; ALBERTI, 2002).

Até o ano de 2011 a UNIBAN contava com oito unidades em São Paulo (Campo Limpo; Santana; Chácara Santo Antônio I e II; Campos Elíseos; Vila Formosa; Vila Guilherme e Vila Mariana); dois campus na Grande São Paulo (São Bernardo do Campo e Osasco), além de unidades em outros estados (Paraná e Santa Catarina). Em setembro deste mesmo ano, a Universidade Bandeirante de São Paulo foi adquirida pela Anhanguera Educacional, instituição que iniciou suas atividades na década de noventa, no interior do Estado de São Paulo. Inicialmente suas unidades estavam presentes nas cidades de Leme, Campinas, Valinhos, Pirassununga e Jundiaí, posteriormente, no início dos anos dois mil, houve a expansão dos seus serviços para as cidades de Santa Bárbara D’Oeste, Limeira, Indaiatuba e Taubaté. Mesmo com 
essa expansão, a instituição identifica o ano de 2007 como um marco significativo do seu processo de crescimento, neste ano a organização:

(...) tornou-se a primeira instituição de ensino brasileira a abrir seu capital na bolsa de valores. A partir deste momento, o crescimento se deu, principalmente, por meio da aquisição de outras instituições de ensino superior, fazendo da Anhanguera Educacional, a maior instituição de ensino superior da América Latina ${ }^{1}$.

O avanço da instituição ao longo dos anos, potencializado por sua inserção na bolsa de valores, resultou na posse de 70 campi e mais de 500 polos de ensino a distância até dezembro de 2012. Em informe divulgado na internet, dirigido aos seus investidores, a organização apresenta um texto informativo que permite notar seu significativo nível de participação no âmbito do sistema educacional profissional privado em todo o país:

A Anhanguera é uma das maiores instituições de Ensino do mundo em número de alunos, bem como uma das maiores empresas de capital aberto do setor de educação no Brasil em termos de valor de mercado. A Companhia tem 490 mil alunos, distribuídos em seus 70 Campus e mais de 500 Polos, localizados em todos os estados brasileiros e também no Distrito Federal. O valor de mercado da Companhia, em 31 de dezembro de 2012, era de R \$ 5,04 bilhões, com base no preço de negociação das ações no encerramento do pregão da BMF \& BOVESPA na referida data. O público-alvo da Anhanguera é composto por adultos das Classes Média e Baixa, que trabalham durante o dia e estudam à noite.

A Anhanguera tem a melhor proposição de valor em Ensino Profissional, permitindo que adultos trabalhadores das Classes Média e Baixa realizem seus projetos de vida por meio de melhoria de sua qualificação profissional e perspectivas de sucesso no mercado de trabalho. Para tanto, a Anhanguera se destaca no mercado por oferecer ensino de qualidade diferenciada ao seu público-alvo, através de uma ampla gama de cursos direcionados a esse segmento, incluindo: graduação, pós-graduação e educação continuada, por meio presencial e à distância, a um custo acessível ${ }^{2}$.

Trata-se, portanto, de uma instituição privada com fins lucrativos, voltada ao atendimento de adultos trabalhadores pertencentes às classes populares, cuja inserção é favorecida por meio da cobrança de mensalidades de valor "acessível". No site da instituição há anúncio de cursos com mensalidades a partir de R\$ 199,00 reais, enquanto a formação em Pedagogia na modalidade presencial possui valor aproximado de $\mathrm{R} \$ 400,00$ reais.

\footnotetext{
${ }^{1}$ Estas informações foram localizadas no site da instituição, na página em que a mesma é apresentada ao leitor, por meio do seguinte endereço: < http://www.uniban.br/institucional/>. Acesso em: 17 set. 2013.

${ }^{2}$ Texto localizado em site da instituição denominado "Relação com investidores - Visão Geral", por meio do seguinte endereço: $<$ http://www.mzweb.com.br/anhanguera2011/web/conteudo_pt.asp?idioma=0\&conta=28\&tipo=39356>. Acesso em: 28 out. 2013.
} 
A UNIBAN unidade Morumbi, situada na Chácara Santo Antônio, campus sede do curso de Pedagogia cujas alunas foram investigadas nesta pesquisa, iniciou suas atividades em 2005, sendo gerida desde 2011 pela Anhanguera Educacional Ltda, passando a possuir desde então a denominação Universidade Bandeirante Anhanguera. Importa destacar que esta unidade foi desativada no encerramento do ano letivo de 2013.

\subsection{O Projeto Pedagógico do Curso de licenciatura em Pedagogia da UNIVERSIDADE BANDEIRANTE ANHANGUERA}

O projeto pedagógico apresentado pela instituição foi elaborado pela Universidade Bandeirante de São Paulo (UNIBAN) no ano de 2010, sendo este o documento que organizou o curso de Pedagogia durante a formação dos alunos investigados nesta pesquisa. Trata-se de um curso seriado e anual, com duração de três anos e carga horária de 3.410 horas $^{3}$, sendo que deste total, 350 horas são dedicadas ao estágio obrigatório e outras 100 horas às atividades teórico práticas de aperfeiçoamento.

A organização curricular do curso se dá a partir da divisão de quatro grandes áreas: Formação Básica; Formação Profissional; Formação Teórico-Prática e Formação Complementar. Na Formação Básica os alunos contam com aulas das disciplinas de Sociologia, História, Filosofia e Psicologia da Educação, e Estrutura e Funcionamento da Educação. A área Formação Profissional, por sua vez, é composta pelas disciplinas de Legislação; Avaliação da Aprendizagem e Aptidões; Gestão Educacional; Planejamento Pedagógico; Organização e Coordenação Pedagógica; Pedagogia Organizacional e Estudos Transversais. Em Formação Teórico-Prática são ministradas as metodologias de alfabetização; geografia; história; língua portuguesa; matemática; ciências; educação especial, além das disciplinas de Didática, Libras e Sistemas de Informação. O último eixo denominado Formação Complementar é o que abrange os estágios em Educação Infantil, Ensino Fundamental e Gestão, Supervisão e Orientação Educacional, além de uma disciplina cursada na modalidade de Educação a Distância (EAD), denominada Estudos Formativos. Nesta disciplina os alunos retomam conteúdos das áreas de Comunicação e expressão; Matemática; Ciências Naturais e Ciências Sociais aplicadas.

Em meio aos objetivos do curso apresenta-se a preocupação em formar professores para a educação infantil, séries iniciais do ensino fundamental e docência no ensino médio na

\footnotetext{
${ }^{3}$ Conforme resolução n ${ }^{\circ} 1$ de 15 de maio de 2006 do Conselho Nacional de Educação.
} 
modalidade normal. Ainda, espera-se preparar gestores de sistemas escolares e não escolares; profissionais capazes de implementar projetos formais e não formais de educação, além de desenvolverem atividades científicas e tecnológicas no campo educacional.

Neste documento a instituição evidencia seu interesse em atender a população oriunda das classes populares, destacando que o valor da mensalidade cobrado permite a inserção de alunos que, por sua formação básica, não teriam condições de ingressar no ensino superior público e, por suas restrições financeiras, não disporiam de recursos suficientes para custear as mensalidades de algumas instituições privadas. Desse modo, a instituição entende que desempenha uma função social ao democratizar o acesso ao ensino superior a uma parcela da população que costumeiramente não reunia condições de frequentar este nível de ensino. Diante deste perfil do seu alunado, a universidade afirma fazer uso de uma prática avaliativa formativa, tendo em vista não só favorecer o acesso, mas também a permanência dos alunos no curso escolhido. Por fim, destaca o oferecimento de mensalidades acessíveis, além de sua participação em programas federais, tais como: Programa Universidade para Todos (PROUNI); Fundo de Financiamento ao Estudante do Ensino Superior (FIES) e programas institucionais que oferecem descontos de $20 \%$ a $60 \%$ nas mensalidades para ex-alunos da instituição que desejem cursar nova graduação ou curso de pós-graduação ${ }^{4}$; alunos ingressante indicados por funcionários da casa ${ }^{5}$; alunos monitores ${ }^{6}$ e estudantes participantes do programa de iniciação científica e tecnológica?

\subsection{Sistema de Ingresso no Curso de licenciatura em Pedagogia da UNIVERSIDADE BANDEIRANTE ANHANGUERA}

A forma de ingresso na Universidade Bandeirante Anhanguera pode ocorrer por meio de três diferentes formas: vestibular tradicional; vestibular planejado e aproveitamento da nota obtida no Exame Nacional do Ensino Médio (ENEM). No vestibular "tradicional" o candidato participa de prova com data e horário estabelecidos pela instituição, enquanto no vestibular

\footnotetext{
${ }^{4}$ Convênio institucional "O bom filho a casa torna" - oferece aos alunos formados pela UNIBAN e instituições de ensino a ela incorporadas ou coligadas, desconto de $20 \%$ sobre as mensalidades dos cursos de graduação e pósgraduação.

${ }^{5}$ Convênio institucional "Bolsa tutor" - bolsas com 30\% de desconto nas mensalidades do curso para alunos ingressantes indicados por funcionários da universidade.

${ }^{6}$ Programa de monitoria - alunos com bom desempenho acadêmico oferecem plantões de dúvida sobre o conteúdo da disciplina e recebem uma bolsa auxílio de $30 \%$ do valor da mensalidade do curso durante o desenvolvimento das atividades.

${ }^{7}$ Programa Institucional de Iniciação Científico-Tecnológica - o aluno recebe $60 \%$ do valor da mensalidade do curso em que estiver matriculado durante o período de realização da pesquisa.
} 
planejado o candidato escolhe, diante da sua disponibilidade, o melhor dia, local e horário de prova. Nesse processo seletivo são avaliados os conhecimentos adquiridos pelos candidatos no âmbito do ensino fundamental e médio, por meio de questões objetivas e redação ${ }^{8}$. Por fim, o ingresso que utiliza o resultado do ENEM dispensa o aluno da necessidade de realização dos vestibulares, mas exige que o candidato tenha obtido aproveitamento mínimo de $20 \%$ em cada uma das disciplinas da prova 9 .

\section{Universidade Federal de São PAUlo (UNIFESP)}

O surgimento da UNIFESP se relaciona com a fundação da Escola Paulista de Medicina (EPM) em 1933 e com a Escola Paulista de Enfermagem em 1939, ambas instituições de caráter privado. No ano de 1956 a Escola Paulista de Medicina foi federalizada - tornandose pública e gratuita - e em 1977 a Escola Paulista de Enfermagem passa pelo mesmo processo quando é incorporada à EPM como Departamento de Enfermagem. Posteriormente novos cursos de graduação na área da saúde foram abertos, tornando a instituição reconhecida pelas atividades de ensino, pesquisa e extensão nesta área específica do conhecimento. Em 1994, por meio da Lei $\mathrm{n}^{\circ} 8.957$ de 15 de dezembro, a instituição foi transformada na Universidade Federal de São Paulo (Universidade Federal de São Paulo, 2008).

A diversificação dos cursos de graduação oferecidos pela Universidade Federal de São Paulo e a expansão do seu atendimento vincula-se às metas estabelecidas pelo Plano Nacional de Educação (PNE - Lei n. 10.172/2001), que indicava a preocupação com o possível aumento na demanda pela educação superior, considerando-se os índices de crescimento nas matrículas no ensino médio e o crescimento efetivo no número de matrículas no ensino superior no final dos anos de 1990. Estas matrículas, porém, ocorreram prioritariamente no ensino privado, constatação que indicou a necessidade da ampliação e fortalecimento do setor público. ${ }^{10}$

\footnotetext{
${ }^{8}$ Informações mais precisas sobre o processo seletivo não foram cedidas pela instituição, bem como não estavam presentes no Projeto Pedagógico disponibilizado pela coordenação do curso. Consultando o gabarito do vestibular no site da Universidade Bandeirante Anhanguera, é possível constatar que atualmente a prova conta com vinte questões: dez delas verificam a capacidade de interpretação de texto do candidato, enquanto as outras dez compreendem perguntas sobre conhecimentos gerais e atualidades. Fonte: < https://www.vestibulares.br/resultados/>. Acesso em: 02 nov. 2013.

${ }^{9}$ Fonte: < http://www.uniban.br/ingresso/graduacao/ENEM.asp>. Acesso em: 02 nov. 2013.

${ }^{10}$ As informações sobre o Plano Nacional de Educação foram obtidas por meio da consulta à referência: BRASIL. Ministério da Educação. Plano Nacional de Educação. Brasília, DF: Senado Federal, 2001. Disponível em:< http://portal.mec.gov.br/arquivos/pdf/pne.pdf>. Acesso em: 15 set. 2013.
} 
Considerando-se as instituições públicas estaduais, municipais e federais, estas tiveram o menor índice de crescimento nas suas vagas entre os anos de 1988 e 1998. Enquanto as municipais tiveram um crescimento de 5,8\% ao ano, as estaduais e particulares atingiram o crescimento de $4,4 \%$, e as federais cresceram apenas $2,9 \%$.

De acordo com o PNE, a ampliação das vagas no ensino superior poderia ocorrer por meio da utilização das vagas ociosas no setor privado, ao mesmo tempo em que as universidades públicas também expandissem suas vagas tendo em vista o atendimento da demanda. No âmbito destas últimas, foi sugerido que a expansão das vagas não fosse inferior a $40 \%$ do total existente. Além disso, o plano ressaltou a importância da expansão das vagas noturnas, a fim de assegurar o acesso ao aluno-trabalhador.

Dentre os objetivos e metas do PNE foi apresentada a expectativa de ampliar para $30 \%$ a proporção de jovens entre 18 a 24 anos matriculados em curso superior até o ano de 2010. Tal meta foi estabelecida diante da constatação de que apenas $12 \%$ da população brasileira entre 18 a 24 anos frequentava esse nível de ensino, sendo este o índice mais baixo de acesso à educação superior, quando considerado o conjunto da América Latina.

Diante deste quadro, no qual se evidenciou a demanda social e as políticas de expansão do ensino superior público, a UNIFESP passou a ampliar seu universo de atuação inaugurando novos campi (Baixada Santista, Diadema, Guarulhos, São José dos Campos e Osasco), oferecendo também cursos em diferentes áreas do conhecimento.

No campus de Guarulhos foi inaugurada a Escola de Filosofia, Letras e Ciências Humanas, no ano de 2007, onde inicialmente eram ministrados os cursos de Graduação em Ciências Sociais (bacharelado e licenciatura), Graduação em Filosofia (bacharelado e licenciatura), Graduação em História (bacharelado e licenciatura) e Graduação em Pedagogia (licenciatura). Em 2009 foram abertos dois novos cursos: História da Arte e curso de Graduação em Letras (bacharelado e licenciatura).

Convém mencionar que a ampliação do atendimento da UNIFESP se relaciona com a a adesão da instituição ao Programa de Apoio a Planos de Reestruturação e Expansão das Universidades Federais (REUNI). Criado por meio do Decreto ${ }^{\circ}$ 6.096, de 24 de abril de 2007, o REUNI teve por objetivo oferecer às universidades federais condições de ampliação das oportunidades de acesso e permanência no ensino superior, sendo uma das ações do Plano do Desenvolvimento da Educação (PDE), lançado no mesmo ano. 
Dentre as diretrizes do Programa, convém destacar a solicitação de que as universidades federais reduzissem as taxas de evasão; promovessem a ocupação das vagas ociosas; aumentassem o número de vagas oferecidas, principalmente no período noturno e ampliassem as políticas de inclusão e assistência estudantil. Além disso, foi requerido que as instituições implantassem currículos flexíveis, os quais permitissem a livre construção do percurso formativo dos alunos; promovessem a elevação da qualidade dos cursos de graduação, fazendo deles cursos preferencialmente não voltados para a "profissionalização precoce e especializada"11 e que procurassem promover a articulação da educação básica com o ensino superior e deste com a pós-graduação. Assim, o curso de Pedagogia da UNIFESP expressa justamente uma resposta ao projeto governamental de expansão das universidades federais. Ao mesmo tempo, é possível notar a observância das orientações oferecidas pelo REUNI em seu projeto pedagógico, o qual será discutido a seguir.

\subsection{O Projeto Pedagógico do Curso de Licenciatura em Pedagogia da UNifesP}

De acordo com o Projeto Pedagógico da UNIFESP, o objetivo principal do curso é formar docentes para a Educação Infantil e anos iniciais do Ensino Fundamental; gestores escolares e pesquisadores, com ênfase na produção e difusão do conhecimento científico e tecnológico no campo da educação.

A fim de superar a fragmentação do conhecimento e a desarticulação entre teoria e prática, o currículo foi organizado por Unidades Curriculares, procurando aproximar disciplinas e atividades que possuam vínculos conceituais. Nas Unidades Curriculares há disciplinas de formação comum aos currículos dos cursos do campus de Guarulhos - atualmente, Leitura e Interpretação de textos e Filosofia Geral; disciplinas básicas - que abrangem matérias de caráter teórico-prático, relacionadas à docência, gestão e pesquisa acadêmica, nas áreas da Filosofia, História, Sociologia, Psicologia, Políticas Públicas; disciplinas específicas, com destaque para as que versam sobre a teoria e a prática da Educação Infantil, anos iniciais do Ensino Fundamental e gestão da educação; disciplinas eletivas que podem ser cursadas no âmbito da Pedagogia ou em outros cursos de graduação do campus de Guarulhos, as quais permitem ao aluno o aprofundamento da sua formação em áreas específicas, a partir de seus interesses e

\footnotetext{
${ }^{11}$ BRASIL. Decreto-lei no 6.096, de 24 de abril de 2007. Institui o Programa de Apoio a Planos de Reestruturação e Expansão das Universidades Federais - REUNI. Diário Oficial da União, Brasília, DF, 25 abr. 2007. Disponível em: <http://www.planalto.gov.br/ccivil_03/_ato2007-2010/2007/decreto/d6096.htm>. Acesso em: 13 set. 2013.
} 
necessidades. As disciplinas de formação comum, básicas, específicas e eletivas são distribuídas ao longo de oito semestres e possuem uma carga horária total de 3.150 horas.

Integrado ao currículo há os estágios obrigatórios, denominados Residência Pedagógica, os quais são realizados na Educação Infantil, no Ensino Fundamental, nos anos iniciais da Educação de Jovens e Adultos e na área da Gestão Educacional. Distribuída entre o quinto e oitavo semestres, a Residência Pedagógica tem duração de 300 horas.

Para o Trabalho de Conclusão de Curso são dedicadas 75 horas de formação na grade curricular, contabilizadas entre as disciplinas básicas do currículo. Assim, a elaboração do TCC é obrigatória e seu ponto de partida são as reflexões elaboradas nas disciplinas de Práticas Pedagógicas Programadas, cursadas nos quatro primeiros semestres e da vivência na Residência Pedagógica, realizada nos quatro últimos semestres da formação do aluno. O objetivo da elaboração obrigatória do TCC é iniciar os alunos na realização de pesquisas sobre as questões educacionais, ampliando a formação científica dos mesmos.

As Atividades Complementares são desenvolvidas pelos alunos ao longo dos quatro anos de formação e são realizadas em 105 horas de dedicação. Tais atividades integram a formação dos alunos por meio da participação ou organização de eventos científicos, grupos de estudo, iniciação científica, monitorias, produção cultural envolvendo a comunidade ou escolas públicas, além do desenvolvimento de estudos e pesquisas inspiradas pela Residência Pedagógica ou pela disciplina de Práticas Pedagógicas Programadas. Estas duas últimas modalidades de atividades são acompanhadas de forma mais próxima por docentes denominados preceptores:

Consideramos a prática do preceptorado como a orientação próxima e sistemática de
um professor junto a um grupo reduzido de estudantes, atuando, para além do ensino
e da experimentação, nas funções de desenvolvimento de qualidades que envolvem o
aprendizado da co-responsabilidade, da autoria coletiva, da formação ética, da
mediação de conflitos, enfim, do preparo para a autonomia intelectual e
responsabilidade profissional dos futuros pedagogos (Universidade Federal de São
Paulo, 2010, p. 27).

Nas Práticas Pedagógicas Programadas os alunos desenvolvem pesquisas de campo, projetos de intervenção na comunidade e experiências educativas - escolares e não escolares, com preferência para esta última, cujos trabalhos são acompanhados pelo professor preceptor. Para estas práticas os preceptores poderão acompanhar até dez estudantes. No caso da Residência Pedagógica em Educação Infantil, anos iniciais do Ensino Fundamental e anos iniciais da Educação de Jovens e Adultos, cada preceptor acompanhará até 6 alunos, enquanto na Residência Pedagógica em Gestão Educacional haverá até 2 estudantes por professor. 
A Residência Pedagógica faz parte de um programa especial de estágios denominado Programa de Residência Pedagógica, cuja efetivação se dá por meio de uma parceria celebrada entre a Universidade e a Secretaria Municipal de Educação de Guarulhos. A proposta é que problemas vivenciados nas escolas sejam tomados como objetos de estudo pelos alunos, cujas reflexões são enriquecidas por meio do diálogo entre seus preceptores, gestores e professores das escolas participantes. A partir deste processo, os alunos poderão implementar ações na escola em que realizam seu estágio, ampliando seu conhecimento sobre a prática docente. Para além disso, está previsto que estas experiências podem alimentar o trabalho de assessoria às escolas e a elaboração de publicações voltadas para residentes e professores da rede pública.

Considerando a carga horária destinada às disciplinas e atividades práticas $(3.150$ horas), ao estágio (300 horas) e às atividades complementares (105 horas), o curso atinge ao término dos oito semestres a duração de 3.555 horas.

Atualmente o curso de Pedagogia Licenciatura da UNIFESP conta com 120 vagas, sendo 60 oferecidas no período vespertino e as outras 60, no período noturno. A ocupação destas vagas ocorre por meio do Sistema de Seleção Unificada (SISU-ENEM), detalhado a seguir.

\subsection{Sistema de Ingresso no Curso de LiCenCiatura em Pedagogia DA UNIFESP}

Entre os anos de 2006 a 2008 o ingresso no curso de Pedagogia da UNIFESP se dava por meio de exame vestibular. Porém, em 2009 e 2010, o processo utilizado para o preenchimento das 120 vagas disponíveis foi o Sistema de Seleção Unificada (SISU-ENEM). O SISU foi desenvolvido em 2009 pelo Ministério da Educação, sendo a seleção realizada considerando-se a nota obtida pelo candidato no ENEM em relação às vagas disponíveis nas Instituições Federais. No processo seletivo do SISU, ao realizar sua inscrição, o candidato escolhe por ordem de preferência até duas opções de cursos que pretende concorrer, dentre as vagas ofertadas pelas instituições participantes. Neste momento o candidato terá também de informar se disputará às vagas de ampla concorrência; às vagas reservadas pela Lei de Cotas ${ }^{12}$

${ }^{12}$ A Lei $\mathrm{n}^{\mathrm{o}} 12.711$, de 29 de agosto de 2012, garante a reserva de 50\% das vagas, por curso e turno das instituições federais de educação superior, para estudantes que tenham cursado integralmente o ensino médio em escolas públicas. Ainda, metade das vagas reservadas $(25 \%)$, será destinada a estudantes com renda familiar bruta igual ou inferior a um salário mínimo e meio per capita. Nas duas situações, também será considerado o preenchimento das vagas por autodeclarados pretos, pardos e indígenas, em proporção mínima igual à de pretos, pardos e indígenas presentes na população da unidade da Federação na qual a instituição está instalada, de acordo com os dados do último censo do Instituto Brasileiro de Geografia e Estatística (IBGE). 
ou às vagas que abrangem outras políticas afirmativas. Após a realização das inscrições, serão divulgadas as notas de corte e a classificação parcial dos candidatos. A partir deste momento, os candidatos poderão alterar suas opções objetivando realizar uma escolha que os mantenha competindo pelas vagas. Esse processo é encerrado com o fechamento definitivo do sistema e com a seleção dos candidatos mais bem classificados em cada curso.

No Edital do vestibular da UNIFESP para o ano de 2010, foi anunciado que o sistema adotado seria justamente o SISU. Para tanto, o Exame Nacional do Ensino Médio de 2009 constituiu-se como etapa obrigatória deste processo seletivo. As notas do ENEM, por sua vez, seriam aproveitadas de duas formas: o Sistema de Seleção Unificado e o Sistema de Seleção Misto. No primeiro sistema - Sistema de Seleção Unificado - foi utilizado somente a nota obtida pelo candidato no ENEM de 2009. Enquanto no segundo sistema, além da nota obtida pelo candidato no ENEM, utilizou-se também a nota obtida pelos candidatos em prova complementar.

No caso do curso de Pedagogia, o sistema utilizado foi o Sistema de Seleção Unificado, devendo o candidato interessado em concorrer pelas vagas, obter em cada uma das cinco áreas de conhecimento avaliadas (Linguagem Códigos e suas tecnologias; Ciências Humanas e suas tecnologias; Ciências da Natureza e suas tecnologias; Matemática e suas tecnologias e Redação) uma nota mínima de $20 \%$. Cada uma das provas nas diferentes áreas do conhecimento possuía o peso de 1,75 , enquanto a redação tinha peso 3,0 .

A UNIFESP reservou neste processo seletivo $10 \%$ das vagas de ingresso para candidatos que se autodeclararam pretos, pardos ou indígenas. Para concorrerem a estas vagas reservadas, vinculadas ao Sistema de Cotas, os candidatos deveriam também ter cursado todo o ensino médio em escolas públicas. Dentre as instituições investigadas nesta pesquisa, a UNIFESP é a única que empregou o sistema de cotas raciais.

Fruto dos esforços da política de ampliação das vagas no ensino superior público, o curso de Pedagogia da UNIFESP é o mais jovem dentre as quatro instituições envolvidas nesta pesquisa. A preocupação com a democratização do acesso ao ensino superior caracteriza o seu processo seletivo, totalmente organizado a partir do resultado do ENEM e da classificação obtida pelos alunos no SISU. Para esta pesquisa é significativo o estudo de uma instituição que recebe em suas graduações estudantes que possuem a oportunidade de assinalar duas opções de cursos e, após a divulgação da nota de corte, alterar tais opções tendo em vista a maximização das chances de aprovação e ingresso no ensino superior. Nesta circunstância, a questão que emerge é como este processo seletivo afeta a escolha da carreira a ser seguida por estes alunos. 


\section{Pontifícia Universidade Católica de São PaUlo (PUC-SP)}

Enquanto no discurso político a educação era defendida como instrumento para a promoção da reconstrução nacional nos anos de 1920, os católicos apresentavam suas reivindicações educacionais, porém, as mesmas eram pouco consideradas no âmbito da Primeira República, decorrência da condição subalterna assumida pela Igreja durante o Império. Com a Revolução de 1930 este quadro se altera, diante da reaproximação entre a Igreja e o Estado, que atendia certas demandas daquela em troca de apoio político. A Igreja católica brasileira, frente aos seus opositores que reivindicavam a laicização do sistema público de ensino, identificados com o movimento escolanovista, preocupou-se com o estabelecimento de uma rede de escolas católicas pelo país, bem como pela fundação de uma instituição de ensino superior que seguisse o modelo da Universidade Católica de Louvain (Bélgica). O interesse subjacente da Igreja era recuperar um poder de atuação mais significativo no meio educacional e social, anteriormente experimentado durante o período colonial, por meio da formação das classes dirigentes de acordo com princípios religiosos cristãos. Tais fundamentos eram guiados pela ideologia disseminada por meio do Centro D. Vital, fundado em 1922, com o propósito de revitalizar o catolicismo brasileiro e seu poder de participação frente aos processos políticos nacionais, por meio da congregação de uma intelectualidade apostólica (SALEM, 1982).

Sob a liderança de D. Leme, Alceu Amoroso Lima e Padre Leonel Franca o Centro D. Vital tem reforçada a ideia de que há uma relação muito próxima entre a função espiritual e cultural da Igreja, entendendo o grupo que a superação das questões que afligiam a nação estava diretamente relacionada com a formação moral das elites. Como consequência, o Centro passa a ceder maior atenção às questões educacionais relacionadas com o ensino superior. Iniciativas como a fundação da Associação dos Universitários Católicos (1929), convertida em 1935 na Juventude Universitária Católica, e o Instituto Católico de Estudos Superiores (1932), representavam a ação da Igreja no meio universitário, sendo este último a instituição embrionária da Universidade Católica. O projeto universitário católico do Centro obteve aprovação de Roma e da Santa Sé e em 1940 o Decreto no. 6.409 autorizou a instalação do curso de bacharelado da Faculdade de Direito e dos cursos da Faculdade de Filosofia. No ano de 1946, diante do número de unidades abrangidas pelas Faculdades Católicas, a instituição assumiu a denominação de Universidade Católica, na cidade do Rio de Janeiro (SALEM, 1982). Neste mesmo ano, a Universidade Católica de São Paulo foi fundada, a partir da junção da Faculdade de Filosofia e Letras de São Bento; Faculdade Paulista de Direito; Faculdade de 
Filosofia, Ciências e Letras "Sedes Sapientiae" (que abrangia o curso de Pedagogia), a Faculdade de Engenharia Industrial, a Faculdade de Filosofia, Ciências e Letras de Campinas e a Faculdade de Ciências Econômicas de Campinas. O reconhecimento da instituição como universidade ocorreu no mesmo ano da sua fundação, recebendo em 1947 o título de Pontifícia por meio do Papa Pio XII. Em 1949, a universidade que estava instalada na Avenida Higienópolis, passa a funcionar no bairro paulista de Perdizes em um prédio que servia de convento às Irmãs Carmelitas Descalças e que foi doado pelas mesmas à instituição.

Inicialmente o objetivo principal da instituição era colaborar no processo de formação profissional, sem que houvesse uma preocupação maior com as atividades de pesquisa (AVELINO, 2011). O interesse em relacionar as atividades de ensino e pesquisa é expresso em 1969, momento em que a PUC-SP cria sua pós-graduação. Neste ano foram inaugurados os Programas de Linguística Aplicada ao Ensino de Línguas; Teoria Literária; Psicologia da Educação e de Sociologia. Posteriormente, em 1978, o contrato de trabalho docente passa a ser regido por tempo de dedicação, movimento que demonstrava, de acordo com a universidade, sua estima pela proximidade entre as atividades de ensino, pesquisa e extensão. Sustentada por esta preocupação foi criado em 1983 a Coordenadoria Geral de Especialização, Aperfeiçoamento e Extensão (Cogeae) que, dentre outras atividades, promove cursos Lato Sensu no âmbito da formação continuada.

Atualmente a universidade conta com 47 cursos de graduação; 28 cursos de Mestrado Acadêmico, 4 cursos de Mestrado Profissional e 21 de Doutorado, além de 330 cursos oferecidos em nível de aperfeiçoamento, especialização e extensão. Estes cursos são distribuídos em seus seis campi: Perdizes, Consolação, Barueri, Santana, Ipiranga e Sorocaba.

A mantenedora da PUC-SP, Fundação São Paulo (FUNDASP), foi instituída em 1945, sendo hoje presidida pelo Cardeal Odilo Pedro Scherer, Arcebispo Metropolitano de São Paulo. Dentre os objetivos ${ }^{13}$ da FUNDASP evidenciam-se:

I - manter e dirigir a Pontifícia Universidade Católica de São Paulo, com as unidades a ela incorporadas a critério do seu Conselho Superior;

III - promover o ensino superior, e em outros níveis, em todas as suas modalidades, inclusive nas áreas profissional e tecnológica, estimulando a investigação, a pesquisa científica e a extensão de serviços à Comunidade;

IV- contribuir para a formação de uma cultura superior adaptada à realidade brasileira e informada pelos princípios da fé católica;

\footnotetext{
${ }^{13}$ Fonte: < http://www.pucsp.br/fundasp/a_fundacao/objetivos.html>. Acesso em: 02 nov. 2013.
} 
V- contribuir para o desenvolvimento da solidariedade entre as democracias, especialmente no campo cultural e social, em defesa da civilização cristã.

Importa destacar que os objetivos indicados pela Fundação são reafirmados pela PUCSP ao comunicar que sua missão é orientada "pelos princípios da doutrina católica", ao mesmo tempo em que procura assegurar "a liberdade de investigação, de ensino e de manifestação de pensamento, objetivando sempre a realização de sua função social, considerada a natureza e o interesse público de suas atividades."14

\subsection{O Projeto Pedagógico do Curso de Licenciatura em Pedagogia da PUC-SP}

De acordo com o Projeto Pedagógico, o curso de Pedagogia da PUC-SP tem por objetivo formar profissionais que exerçam a docência na Educação Infantil; nos anos iniciais do Ensino Fundamental e atuem como gestores dos processos educativos. Para tanto, entendese como necessário proporcionar aos cursistas formação teórica e interdisciplinar, fundamentada em conhecimentos científicos, permitindo ao aluno o exercício de sua profissão, compreendendo-a em seus aspectos filosófico, político, social e histórico. Espera-se que os alunos desenvolvam ao longo do curso competências e habilidades, não entendidas como o domínio de um conjunto de métodos e técnicas, mas sim como a consolidação de sujeitos inseridos em uma determinada realidade histórica, "co-participante(s) na transformação das relações de poder" e comprometidos com a escola pública (Projeto Pedagógico do Curso de Pedagogia PUC-SP, 2006, p.79/80).

A proposta de formação do aluno no curso de Pedagogia compreende três núcleos fundamentais: 1) Estudos Básicos; 2) Aprofundamento e Diversificação de Estudos e 3) Estudos Integradores. O núcleo de Estudos Básicos é composto pelas teorias educacionais que fundamentam os debates educativos, a prática pedagógica e as situações de gestão do trabalho escolar. O núcleo de Aprofundamento e Diversificação de Estudos, por sua vez, possibilita a aproximação entre as teorias educacionais e situações pedagógicas concretas, inseridas em contextos escolares ou em ambientes educativos diversos, considerando-se o cenário social e cultural brasileiro. Este núcleo oferece aos alunos a possibilidade de escolherem uma unidade eletiva, permitindo aos mesmos que participem da composição de sua trajetória formativa. Por fim, o núcleo de Estudos Integradores é composto por "Atividades Complementares" e por "Atividades em aberto". As "Atividades Complementares" são oferecidas pelo curso e

\footnotetext{
${ }^{14}$ Fonte: < http://www.pucsp.br/universidade/sobre-a-universidade>. Acesso em: 02 nov. 2013.
} 
envolvem a participação dos alunos em oficinas, seminários, simpósios, palestras e atividades afins, além da participação dos mesmos em projetos de iniciação científica, publicações acadêmicas e relatórios de pesquisa. Nesta modalidade também são considerados os estágios extra-curriculares realizados pelos alunos, seja em instituições escolares ou não, e atividades socioculturais como participação em atividades artísticas, estudos do meio, visitas culturais, dentre outras. As "Atividades em aberto", por sua vez, abrangem as atividades que possuem o mesmo caráter das "Atividades Complementares", com a diferença que as mesmas são escolhidas a partir do interesse e da iniciativa do aluno. Para que as mesmas sejam validadas, a escolha dos estudantes dependerá do aval dos professores do curso.

Tendo em vista a formação dos alunos de modo interdisciplinar, o currículo do curso de Pedagogia foi organizado em Módulos, Eixos e Unidades Temáticas, exigindo por parte dos professores a realização de um trabalho articulado. Os módulos são anuais, assim contam-se quatro módulos ao longo de todo o curso: Educação e realidade brasileira: desafios $\left(1^{\circ} \mathrm{ano}\right)$; Educação: docência e gestão na educação infantil ( $2^{\circ}$ ano); Formação para a docência escolar ( $3^{\circ}$ ano) e Gestão e docência: projetos educativos ( $4^{\circ}$ ano). Cada módulo possui dois eixos, ministrados no primeiro e no segundo semestres do ano letivo. A partir dos eixos desdobram-se as Unidades Temáticas, as quais podem ser entendidas como as disciplinas que compõem o curso, cujas características aproximam-nas de algum dos três núcleos fundamentais.

A interdisciplinaridade também se manifesta por meio das Unidades Temáticas do curso de Pedagogia que se relacionam com outras áreas do conhecimento, tais como Matemática, Português, História, Geografia e Ciências. Para estas disciplinas foram estabelecidas parcerias entre os professores do curso de Pedagogia e docentes de departamentos afins aos das disciplinas indicadas. A colaboração entre os docentes abrange o trabalho de desenvolvimento das Unidades Temáticas e realização de atividades conjuntas tais como aulas, seminários e oficinas.

É importante notar que na estrutura do currículo as "Vivências Educadoras - Práticas de Investigação" permeiam todo o percurso formativo, atendendo o objetivo de organização de um curso pautado pela articulação entre teoria e prática, bem como pela indissociabilidade entre ensino e pesquisa. Por meio das Vivências Educadoras - Práticas de Investigação, os alunos tomam sua própria prática pedagógica como objeto de estudo, esperando-se que por meio dessa experiência os estudantes adquiram a capacidade de problematizar, refletir, (re)planejar e avaliar situações relacionadas ao cotidiano da profissão. Assim, o currículo procura integrar 
práticas de pesquisa ao longo do processo formativo, culminando na elaboração do Trabalho de Conclusão do Curso (TCC), apresentado no último ano da graduação.

A relação teoria e prática também é favorecida por meio da realização do Estágio Supervisionado. Para esta atividade são destinadas 300 horas, divididas entre Educação Infantil; séries iniciais do Ensino Fundamental e Gestão. Os estágios realizados são supervisionados por professores que acompanham semanalmente as atividades desenvolvidas pelos alunos, por meio do acompanhamento do relato das experiências de um pequeno grupo de estudantes. As atividades desenvolvidas durante o estágio são debatidas, avaliadas e novamente planejadas. Acredita-se que esta maneira de conduzir o estágio favoreça o desenvolvimento da identidade profissional dos cursistas, a partir da aproximação entre "os conhecimentos teóricos e (...) os saberes da ação" (Projeto Pedagógico do Curso de Pedagogia PUC-SP, 2006, p.178).

Considerando-se a carga horária do curso, o mesmo conta com 3.200 horas, sedo que destas, 100 horas são cumpridas na modalidade a distância. As cem horas de Atividades Complementares e as trezentas horas de estágio, por sua vez, são contabilizadas fora da matriz horária. O curso tem duração de quatro anos, organizados semestralmente e é ministrado tanto no período matutino, quanto no período noturno, sendo disponibilizadas oitenta vagas em cada um dos turnos, além de quarenta novas vagas abertas para o vestibular de inverno.

\subsection{Sistema de Ingresso no CURSo de LiCenciatura em Pedagogia da PUC-SP}

O ingresso na Pontifícia Universidade Católica de São Paulo se dá por meio de exame vestibular, agendado previamente pela instituição. A instituição realiza dois grandes vestibulares: no meio (vestibular de inverno) e no final do ano. A prova ocorre em data única e é composta por 45 questões de múltipla escolha, uma redação e três questões discursivas. Os candidatos selecionados serão os mais bem classificados em sua respectiva opção de curso e turno, de acordo com a quantidade de vagas disponíveis. Havendo interesse por parte do candidato, a instituição oferece ainda a opção de ingresso em cursos com vagas remanescentes, caso a classificação obtida no exame permita.

De acordo com dados do vestibular do final do ano de $2009^{15}$, sistematizados pela Coordenadoria de Vestibulares e Concursos da PUC-SP, inscreveram-se no curso de Pedagogia, na unidade de Perdizes, quarenta e cinco candidatos interessados nas vagas do período matutino e trinta e nove candidatos no período noturno. Destes, trinta e um efetivaram sua matrícula no

${ }^{15}$ Foram utilizados os dados do vestibular de 2009 , visto que os alunos investigados nesta pesquisa participaram especificamente desta seleção, tendo em vista o início do curso no ano de 2010. 
período matutino, enquanto vinte e um matricularam-se no período noturno. Considerando as vagas disponíveis pela instituição - 80 para cada um dos turnos, de acordo com dado divulgado no projeto pedagógico, nota-se que a oferta de vagas é maior que a demanda.

No Projeto Pedagógico do curso é indicada a preocupação em torno do valor da mensalidade referente à graduação em Pedagogia, a respeito da qual, comenta-se: "Sua mensalidade atual de $\mathrm{R} \$ 1.018,00$ (mil e dezoito reais), a mais cara do Brasil, é um fator fortemente impeditivo para o ingresso de alunos das camadas populares, o que coloca em risco o papel social do Curso de Pedagogia da PUC-SP." (Projeto Pedagógico do Curso de Pedagogia PUC-SP, 2006, p.76). De acordo com o manual do candidato ao vestibular de 2014, a instituição afirma que "A concessão de bolsas de estudo é uma das principais formas de inclusão na Universidade." ${ }^{16}$ Para tanto, a instituição concede bolsas de caráter institucional, além de participar dos programas federais: Programa Universidade para Todos (PROUNI) e Fundo de Financiamento Estudantil (FIES). Os alunos ingressantes via PROUNI são dispensados da realização do vestibular, visto que o ingresso dos mesmos se dá por meio da nota obtida no Exame Nacional do Ensino Médio (ENEM).

\section{Faculdade de Educação da Universidade de São Paulo (FEUSP)}

O interesse pela criação de um curso superior para a formação e o aperfeiçoamento do magistério fazia parte de projeto educacional republicano, que por meio da Lei Estadual $\mathrm{n}^{\mathrm{o}} 88$ de 1892, responsável pela reforma da Instrução Pública do Estado de São Paulo, propôs a criação de um Curso Superior, anexo à Escola Normal da Praça. Tal proposta não foi executada, assim como a criação da Faculdade de Educação concebida em 1920, no interior do planejamento reformista de Sampaio Doria (ANTUNHA, 1975).

Em 1933, convém destacar a abertura do Instituto de Educação, o qual foi incorporado pela Universidade de São Paulo em seu Decreto de Fundação. De acordo com Antunha (1975, p.34) o Instituto de Educação representa o "antepassado mais direto da atual Faculdade de Educação da USP". A história do Instituto de Educação teve início em 1931 com a reforma da

\footnotetext{
${ }^{16}$ Fonte: <http://www.vestibular.pucsp.br/downloads/vestibular-unificado/Manual_Candidato2014.pdf $>$. Acesso em: 05 nov. 2013.
} 
Escola Normal da Praça, que por meio do Decreto Estadual n ${ }^{\circ} 4888$, assumiu a denominação de Instituto Pedagógico, onde passou a ser oferecido o Curso de Aperfeiçoamento Pedagógico, que tinha por objetivo proporcionar formação técnica a inspetores, delegados de ensino, diretores e professores do curso normal. Em 1933, o Instituto Pedagógico, por meio dos Decretos 5846 e 5844, passou a denominar-se Instituto de Educação, assumindo o caráter de instituição de ensino superior justamente ao ser incorporado pela Universidade de São Paulo (FÉTIZON, 1978; 1994).

Extinto em 1938, o Instituto de Educação passou por mudanças sucessivas. Inicialmente convertido em Secção de Educação da Faculdade de Filosofia, Ciências e Letras, posteriormente assumiu a denominação de Secção de Pedagogia e em 1962 transformou-se em Departamento de Educação da Faculdade de Filosofia, Ciências e Letras. Por fim, com a Reforma Universitária e a definição dos novos Estatutos da Universidade de São Paulo foi criada em 1969 a Faculdade de Educação que entrou em funcionamento no ano de 1970 (ANTUNHA, 1975; FÉTIZON, 1978; 1994).

A Faculdade de Educação, além de oferecer a graduação em Pedagogia, assumiu significativa participação no campo da investigação pedagógica, desenvolvendo programa de Pós-Graduação, criado em 1971. Além disso, a instituição também se responsabilizou por pela formação nos cursos de licenciatura. As atividades de ensino e pesquisa ocorrem até os dias de hoje, com o acréscimo dos projetos de extensão universitária e serviços à comunidade, distribuídos entre os três departamentos da Faculdade: Departamento de Administração Escolar e Economia da Educação (EDA); Departamento de Filosofia da Educação e Ciências da Educação (EDF) e Departamento de Metodologia do Ensino e Educação Comparada (EDM).

\subsection{O Projeto Político Pedagógico do Curso de licenciatura Plena em PEDAGOGIA DA FEUSP}

Em 1970, ano de inauguração da Faculdade de Educação da USP, o curso de Pedagogia possuía quatro anos de duração, sendo que o último ano era destinado ao cumprimento de uma das três modalidades de habilitação oferecidas - Administração Escolar, Supervisão Pedagógica e Orientação Educacional. Após a conclusão do curso, os alunos que tivessem interesse poderiam retornar à Faculdade e frequentar outras habilitações (FÉTIZON, 1978; 1994).

De acordo com Chamlian (1996), o currículo implantado em 1970 sofreu sua primeira reformulação em 1987, envolvendo o acréscimo de disciplinas e a modificação de programas. 
O planejamento desta nova reformulação curricular foi efetivada a partir de estudos que investigaram o perfil dos cursistas e o destino ocupacional dos egressos. Tais levantamentos indicaram a existência de deficiências que envolviam elevados índices de evasão e retenção nos dois primeiros anos do curso, principalmente, no período noturno. Além disso, verificou-se que grande parte dos concluintes trabalhavam no âmbito de escolas públicas, fazendo com que a universidade retomasse sua atenção para a formação do educador que atuaria nessas instituições. Com a reforma curricular de 1990, o curso de quatro anos habilitaria os estudantes a exercerem o magistério de $1^{\circ}$ e $2^{\circ}$ graus. De modo complementar, os alunos poderiam cursar habilitações em Orientação Educacional, Supervisão Escolar, Administração e Inspeção Escolar, Ensino de Deficientes Mentais e Ensino de Deficientes Visuais. As habilitações só poderiam ser realizadas pelos alunos após os quatro anos de formação básica, ampliando a duração do curso pelo período de um ano a seis meses, dependendo do tipo de habilitação escolhida pelo cursista.

Já no ano de 1993, uma avaliação interna do curso de Pedagogia indicou novamente apreensões em torno do perfil profissional dos formandos e da estrutura curricular utilizada. Os principais problemas indicados envolviam "número elevado de disciplinas por semestre" e "oferta insuficiente de disciplinas optativas". Ao mesmo tempo os alunos reportavam sua insatisfação com o fato de optarem necessariamente por uma área de aprofundamento da sua formação, oferecendo um preparo profissional por eles interpretado como incompleto. A desarticulação entres as disciplinas e superposição de conteúdos, entre outros aspectos, foram identificados, motivando uma nova reforma curricular implementada em 1999 (CHAMLIAN, 1996, p. 144). Nessa reforma, o curso de Pedagogia incorporou todas as habilitações à formação básica. Assim, após os quatro anos de formação, o aluno teria as habilitações para o Magistério em Educação Infantil, Ensino Fundamental e matérias pedagógicas do Ensino Médio; Administração Escolar; Supervisão Escolar e Orientação Educacional. ${ }^{17}$

Objetivando adequar o curso às Diretrizes Curriculares Nacionais para a Formação de Professores estabelecidas em 2002 e às Diretrizes Curriculares para os Cursos de Pedagogia propostas pelo Conselho Nacional de Educação em 2006, nova reformulação foi necessária, resultando na inclusão de quatro disciplinas obrigatórias na grade curricular, ampliando a duração mínima do curso de quatro anos para quatro anos e meio.

\footnotetext{
${ }^{17}$ As informações apresentadas a seguir foram obtidas no documento "Projeto Político-Pedagógico do curso de Licenciatura Plena em Pedagogia". Disponível em: <http://www4.fe.usp.br/wpcontent/uploads/graduacao/ppppedagogiaversao.pdf> Acesso em: 02 mar. 2013.
} 
Recentemente nova reformulação do curso foi planejada (ano de 2011) e implementada (ano de 2012), centrada principalmente em uma organização curricular ordenada por três opções de percursos formativos: "Escolarização e Docência", "Política e Gestão" e "Educação e Cultura", a serem oferecidos aos alunos, cuja escolha se dá a partir de seus interesses formativos. Flexível, o currículo vigente possui vinte e oito disciplinas obrigatórias e onze disciplinas optativas, dentre as quais oito são eletivas e cursadas a partir do percurso formativo escolhido pelo aluno. As outras três disciplinas são optativas livres, podendo o aluno cursá-las tanto na FEUSP, quanto em outras unidades da USP ou até mesmo em outras universidades.

Com duração mínima de quatro anos e meio, o curso completo é realizado em 3.270 horas, sendo que 450 horas são destinadas às atividades práticas, desenvolvidas na forma de Estágios Curriculares Obrigatórios. A partir do quarto semestre há períodos vagos em horário semanal para realização de Atividades Práticas de Estágios Curriculares Obrigatórios, sendo a rede pública de ensino privilegiada como local para a realização dos mesmos, havendo a prática do estabelecimento de convênios.

Além do estágio curricular obrigatório os alunos realizam ao longo do curso 570 horas de Atividades Práticas, tais como leituras, trabalhos e pesquisas orientadas, em todas as disciplinas obrigatórias e outras 480 horas de Estudos Independentes que abrangem a participação em seminários; oficinas; jornadas; encontros; congressos; pesquisas acadêmicas; consultas a bibliotecas e centros de documentação; museus; instituições educacionais e culturais; grupos de estudos; pesquisas de iniciação científica; participação em eventos acadêmicos; dentre outras atividades relacionadas à educação que favorecem o enriquecimento da formação curricular e profissional dos alunos. Por fim, é facultada ao aluno a elaboração do Trabalho Complementar de Curso, compreendendo 180 horas de formação, tendo em vista o aperfeiçoamento da prática de pesquisa entre os cursistas.

A prática da pesquisa entre os alunos do curso de licenciatura em Pedagogia atende a um dos objetivos do curso de iniciar os estudantes nas atividades de investigação das questões educacionais, perpetuando uma intenção presente nos cursos de graduação da Universidade de São Paulo em manter a indissociabilidade entre as atividades de docência, pesquisa e extensão. Espera-se que a prática da pesquisa ofereça ao cursista a capacidade de compreender os problemas educacionais e adquirir uma postura crítica frente às práticas, cultura e saberes escolares, aprofundando assim a formação teórica adquirida em sala de aula. 
A partir da formação teórica, prática e cultural obtida pelos alunos ao longo do curso, os mesmos poderão exercer após a sua conclusão: 1) a função docente no âmbito da educação infantil, séries iniciais do Ensino Fundamental e disciplinas pedagógicas do Ensino Médio na Modalidade Normal. Além disso, os formandos poderão atuar como professor especialista em instituições que atendam crianças, jovens e adultos, sem ou com necessidades educacionais especiais; 2) a função de gestão desenvolvendo as atividades de direção, orientação educacional, coordenação pedagógica e supervisão de ensino; 3) Assessoria e Atividade especializada por meio de serviços de assessoria pedagógica, planejamento, execução e coordenação de projetos e experiências educativas, além de atuar como especialista em produção, pesquisa e difusão do conhecimento científico-tecnológico do campo educacional.

Desde o ano de 2001 houve a ampliação das vagas oferecidas no período noturno, passando de sessenta para cento e vinte vagas, enquanto no período vespertino a oferta de sessenta vagas foi mantida. Assim, considerando os dois períodos, são oferecidas 180 vagas para alunos ingressantes, cuja seleção ocorre via Fundação Universitária para o Vestibular (FUVEST).

\subsection{SISTEMA DE INGRESSO NA FACULDADE DE EDUCAÇÃO DA USP}

Considerando o perfil dos alunos que participaram do levantamento realizado nesta investigação - formandos que estivessem frequentando seu último ano no curso de graduação em Pedagogia - e a duração de quatro anos e meio do curso na Faculdade de Educação da USP, é possível admitir que os alunos investigados ingressaram na instituição entre os anos de 2009 e 2010. Tal como foi dito anteriormente, o acesso à FEUSP ocorre por meio do vestibular da FUVEST e interessa-nos neste momento conhecer a os critérios de seleção e pontuação dos candidatos, a relação candidato-vaga e a nota de corte utilizada para o curso de Pedagogia especialmente entre os anos indicados.

O exame na primeira fase do vestibular de 2009 continha 90 questões objetivas, valendo 1 ponto cada uma, as quais tratavam do conjunto das disciplinas estudadas durante o Ensino Médio: Português, Matemática, História, Física, Geografia, Química, Biologia e Inglês. O aluno que obteve um número de acertos inferior a 22 questões, sofreu a eliminação do processo seletivo. O desempenho nesta prova, realizada em um único dia pelo tempo máximo de cinco horas, poderia ser complementado com o aproveitamento dos pontos obtidos no Exame Nacional do Ensino Médio (ENEM) realizado pelos candidatos no ano de inscrição no 
vestibular e no ano antecedente, sendo utilizado pela FUVEST o melhor resultado obtido entre os dois anos.

É importante salientar que a composição final dos pontos da primeira fase é calculada de forma diferenciada para estudantes egressos do Ensino Médio Público, considerando-se o Programa de Inclusão Social da USP (INCLUSP), criado em 2006. Tal programa tem por objetivo incentivar a participação dos alunos de escola pública no vestibular e ampliar as possibilidades de acesso. Após o ingresso do candidato, a política de inclusão volta-se para a promoção de ações que favoreçam a permanência dos alunos com desvantagens socioeconômicas por meio do oferecimento de bolsas e auxílios (alimentação, saúde, moradia...) durante a graduação.

Uma das ações do INCLUSP é o Sistema de Pontuação Acrescida por meio do qual estudantes que cursaram integralmente o Ensino Médio em escolas públicas sofreram um fator de acréscimo de $3 \%$ sobre as notas obtidas na primeira e segunda fases. Além do Sistema de Pontuação Acrescida, o candidato que participou do ENEM e cursou o Ensino Médio integralmente em escola pública, pôde ter ainda um aumento de até mais $6 \%$ na sua pontuação, variável de acordo com o desempenho obtido neste exame. Outra ação do INCLUSP é o Programa de Avaliação Seriada da USP (PASUSP), criado em 2008. Esse programa ofereceu bônus de até 3\% na pontuação da primeira e segunda fase da FUVEST, para alunos do terceiro ano do Ensino Médio público que se inscreveram e realizaram prova específica composta por cinquenta questões objetivas. Considerando os três tipos de bônus, as notas obtidas pelos candidatos no vestibular de 2009, que participaram do INCLUSP, puderam obter um acréscimo máximo de até $12 \%$.

A segunda fase da FUVEST é composta por prova analítico-expositiva e só é realizada pelos alunos que obtiveram pontuação igual ou superior à nota de corte estabelecida para a carreira. No caso do curso de Pedagogia, no vestibular de 2009, a nota de corte foi de trinta e oito pontos. Na primeira fase a relação candidato vaga foi de 7.56, enquanto na segunda fase a relação foi de 3.43 candidatos convocados por vaga.

A prova da segunda fase para os candidatos ao curso de Pedagogia abrangeu a realização de provas específicas nas disciplinas de Língua Portuguesa - que compreendeu a elaboração de uma redação, além da necessidade de responderem dez questões de interpretação de textos, gramática e literatura - e História. 
No ano de 2010 a primeira fase do exame não sofreu alterações, porém, enquanto em 2009 as notas obtidas na primeira fase foram utilizadas para o cálculo da média final do candidato, em 2010 essa nota foi utilizada somente como critério para a participação do aluno na segunda fase do vestibular. A segunda fase do vestibular também sofreu mudanças já que avaliou todas as matérias do ensino médio, enquanto em 2009 só as disciplinas específicas relacionadas à carreira deveriam ser verificadas, no caso da Pedagogia, somente Língua Portuguesa e História.

Quanto à utilização da nota do ENEM, o manual da FUVEST de 2010 indicava que o resultado desse exame seria utilizado na composição da nota obtida na primeira fase do vestibular, entretanto, diante do vazamento do conteúdo da prova do ENEM e do deslocamento da data da prova para o início de dezembro, a USP divulgou um comunicado informando que a FUVEST não utilizaria mais a nota do ENEM, pela incompatibilidade entre o calendário de provas. Com isso, a nota da primeira fase do exame da FUVEST consistiu no exato número de acertos obtido pelo candidato na prova de noventa questões do vestibular.

Pelo fato da FUVEST desconsiderar o ENEM no vestibular de 2010, o INCLUSP também sofreu alterações no que se refere ao cálculo dos bônus, que passou a ser aferido considerando-se a pontuação da primeira fase do exame. A partir de 22 pontos, os candidatos receberam bonificações que variavam de $1,8 \%$ a $6 \%$, dependendo do número de acertos obtidos. Além desta bonificação, o INCLUSP ofereceu 3\% a mais para estudantes oriundos de escolas públicas e até 3\% de bonificação para quem fez a prova do Programa de Avaliação Seriada da USP (PASUSP).

Dentre as quatro instituições investigadas, a FEUSP é a mais antiga, considerando-se sua origem vinculada à abertura do Instituto de Educação, em 1933. Em termo de duração mínima seu curso é o mais longo e o que exige o maior número de horas em termos de estágio obrigatório. Além disso, deve-se destacar o volume de sua oferta de vagas anuais, com destaque para o período noturno. Seu processo seletivo para os alunos ingressantes distingue-se pelo incentivo e ampliação das possibilidades de acesso aos estudantes oriundos da escola pública, resultantes das medidas tomadas pelo Programa de Inclusão Social da USP (INCLUSP), criado em 2006. Em 2010, a nota de corte na primeira fase foi de vinte e três pontos, sendo 4,16 a relação candidato vaga. Observando-se a nota de corte dos demais cursos, é possível constatar que apenas quatro exigiram pontuação abaixo da demandada pelo curso de Pedagogia, dentre os quais constam: Ciências da Informação e da Documentação - Ribeirão Preto; Música - São Paulo e Ribeirão Preto; Ciências da Atividade Física - USP Leste e Fonoaudiologia-Bauru. O 
estudo do perfil de seus alunos torna-se significativo, considerando-se o impacto dos esforços de democratização expressos pela ampliação de vagas no período noturno e as medidas inclusivas do vestibular da USP. 